\title{
Design, optimization, and study of small molecules that target tau pre- mRNA and affect splicing
}

\section{Supporting Information}

\author{
Jonathan L. Chen ${ }^{1, a}$, Peiyuan Zhang1,a, Masahito Abe1, Haruo Aikawa1 ${ }^{1}$, Liying Zhang ${ }^{3}$, \\ Alexander J. Frank ${ }^{2}$, Timothy Zembryski ${ }^{2}$, Christopher Hubbs ${ }^{1}$, HaJeung Park ${ }^{1}$, Jane Withka ${ }^{3}$, \\ Claire Steppan ${ }^{4}$, Lucy Rogers ${ }^{4}$, Shawn Cabral ${ }^{4}$, Martin Pettersson ${ }^{3}$, Travis T. Wager ${ }^{3,5}$, Matthew \\ A. Fountain ${ }^{2}$, Gavin Rumbaugh ${ }^{1}$, Jessica L. Childs-Disney ${ }^{1}$, and Matthew D. Disney ${ }^{1 *}$ \\ ${ }^{1}$ Department of Chemistry and Neuroscience, The Scripps Research Institute, 130 Scripps \\ Way, Jupiter, FL 33458 USA \\ ${ }^{2}$ Department of Chemistry \& Biochemistry, State University of New York at Fredonia, 311 \\ Science Center, Fredonia, NY 14063 USA \\ ${ }^{3}$ Pfizer Worldwide Research and Development, Cambridge, MA 02139 USA \\ ${ }^{4}$ Pfizer Worldwide Research and Development, Groton, CT 06340 USA \\ ${ }^{5}$ Present address: Rgenta Therapeutics, 15 Lincoln Rd, Brookline MA 02445 USA \\ a These authors contributed equally to this work \\ * Author to whom correspondence is addressed: Email: Disney@scripps.edu
}




\section{Contents}

$\begin{array}{ll}\text { Supplementary Results } & 6\end{array}$

$\begin{array}{ll}\text { Supplementary Figures } & 10\end{array}$

Figure S1 Set of 20 compounds identified by Inforna and screened in cell-based 10 luciferase assay.

Figure S2 The effect of Inforna-derived compounds on expression of luciferase in cell-based assays.

Figure S3 The effect of Inforna-derived compounds 1 to 4 on expression of luciferase in cell-based assays.

Figure S4 The effect of compounds 4 to 9 on expression of luciferase in BE(2)M17 cells stably transfected with a minigene expressing DDPAC Tau.

Figure S5 The effect of 2-AP substitutions at different sites of the WT duplex on fluorescence induced by binding of 4 .

Figure S6 Binding assays of 4 and hairpin and duplex constructs used in this study.

Figure S7 Cell toxicity data for compounds 4 to 9 assessed by cell viability reagent.

Figure S8 The effect of hit compounds on relative amounts of $4 R$ and $3 R$ Tau mRNA assessed by RT-qPCR.

Figure S9 Protein modulation with compound 9 and 4R-to-3R ASO treatment.

Figure S10 The effect of compounds $\mathbf{9}$ and $\mathbf{1 1}$ on expression of luciferase in HeLa cells transfected with WT, DDPAC, WT+l17T, and DDPAC+117T minigenes, and in $B E(2)-M 17$ cells stably transfected with a minigene expressing DDPAC tau.

Figure S11 The effect of 11 on relative amounts of $4 R$ and $3 R$ tau pre-mRNA assessed by RT-qPCR in HeLa cells transfected with WT, DDPAC, $\mathrm{WT}+\mid 17 \mathrm{~T}$, and DDPAC+I17T minigenes, and in LAN5 neuroblastoma cells.

Figure S12 The effect of increasing concentrations of 11 and 12 on amounts of DDPAC and DDPAC+I17T mutant RNAs pulled down in Chem-CLIP experiments.

Figure S13 Results of in vitro C-Chem-CLIP experiments with WT and DDPAC RNAs and 9 and 11.

Figure S14 The effect of 11 on relative amounts of MAPT mRNAs and mRNAs with IRE pulled down in Chem-CLIP experiments. 
Figure S15 The effects of compounds 7 and 9 on microRNA expression.

Figure S16 The effect of gentamicin on relative amounts of $4 R$ and 3R Tau mRNA in LAN5 cells assessed by RT-qPCR.

Figure S17 The effect of compounds $\mathbf{4}$ to $\mathbf{9}$ on the thermodynamic stability of Tau RNA constructs.

Figure S18 1D ${ }^{1} \mathrm{H}$ and WaterLOGSY NMR spectra of 4.

Figure S19 Imino proton regions of $1 \mathrm{D}$ and 2D ${ }^{1} \mathrm{H}$ NOESY NMR spectra of the unbound WT Tau RNA duplex.

Figure S20 Imino proton regions of 1D and 2D ${ }^{1} \mathrm{H}$ NOESY NMR spectra of the unbound DDPAC Tau RNA duplex.

Figure S21 NMR titrations of WT and DDPAC stem mimic duplexes with 4.

Figure S22 1D and 2D ${ }^{1} \mathrm{H}$ NOESY NMR spectra of the WT Tau RNA duplex bound to 4 showing imino proton regions.

Figure S23 Imino proton region of 1D ${ }^{1} \mathrm{H}$ NMR spectra of unbound WT and DDPAC Tau RNA duplexes from 2 to $40{ }^{\circ} \mathrm{C}$.

Figure S24 Imino proton region of $1 \mathrm{D}{ }^{1} \mathrm{H}$ NMR spectra of 4-bound WT and DDPAC Tau RNA duplexes from 2 to $40^{\circ} \mathrm{C}$.

Figure S25 $\mathrm{H} 1{ }^{\prime}-\mathrm{H} 6 / \mathrm{H} 8$ region of a $2 \mathrm{D}{ }^{1} \mathrm{H}$ NOESY NMR spectrum of the unbound WT Tau RNA duplex

Figure S26 $\mathrm{H} 1^{\prime}-\mathrm{H} 6 / \mathrm{H} 8$ region of a 2D ${ }^{1} \mathrm{H}$ NOESY NMR spectrum of the unbound DDPAC Tau RNA duplex.

Figure S27 $\mathrm{H} 1{ }^{\prime}-\mathrm{H} 6 / \mathrm{H} 8$ region of a $2 \mathrm{D}{ }^{1} \mathrm{H}$ NOESY NMR spectrum of the 4-WT Tau RNA.

Figure S28 Overlay of the 10 lowest free energy structures of free- and bound-form Tau WT stem mimic RNA duplexes.

Figure S29 1D ${ }^{1} \mathrm{H}$ and WaterLOGSY NMR spectra of 5.

Figure S30 1D ${ }^{1} \mathrm{H}$ and WaterLOGSY NMR spectra of 9.

Figure S31 1D ${ }^{1} \mathrm{H}$ and WaterLOGSY NMR spectra of 6.

Figure S32 1D ${ }^{1} \mathrm{H}$ and WaterLOGSY NMR spectra of 7.

Figure S33 1D ${ }^{1} \mathrm{H}$ and WaterLOGSY NMR spectra of 8.

Figure S34 NMR titrations of WT and DDPAC stem mimic duplexes with 5. 
Figure S35 NMR titrations of WT and DDPAC stem mimic duplexes with 6.

Figure S36 NMR titrations of WT and DDPAC stem mimic duplexes with 7.

Figure S37 NMR titrations of WT and DDPAC stem mimic duplexes with 9.

Figure S38 $\mathrm{H} 6 / \mathrm{H} 8-\mathrm{H} 1^{\prime}$ region of a $2 \mathrm{D}{ }^{1} \mathrm{H}$ NOESY NMR spectrum of the 5-WT tau RNA complex.

Figure S39 $\mathrm{H6} / \mathrm{H} 8-\mathrm{H} 1$ ' region of a $2 \mathrm{D}{ }^{1} \mathrm{H}$ NOESY NMR spectrum of the 9-WT tau RNA complex.

Figure S40 Imino proton regions of 1D and 2D ${ }^{1} \mathrm{H}$ NOESY NMR spectra of the WT Tau RNA duplex bound to 5 .

Figure S41 Imino proton regions of 1D and 2D ${ }^{1} \mathrm{H}$ NOESY NMR spectra of the WT Tau RNA duplex bound to 9.

Synthesis of compounds 5-7, 9, 10, and Chem-CLIP probe 11

Supplementary Tables

Table S1 Results of 1D NMR spectroscopy of the WT and DDPAC stem mimic duplexes with lead compounds.

Table S2 $\quad{ }^{1} \mathrm{H}$ NMR chemical shifts of the unbound WT stem mimic.

Table S3 $\quad{ }^{1} \mathrm{H}$ NMR chemical shifts of the unbound DDPAC stem mimic.

Table S4 $\quad{ }^{1} \mathrm{H}$ NMR chemical shifts of the 4-bound WT stem mimic complex.

Table S5 $\mathrm{K}_{d} \mathrm{~S}$ or $\mathrm{IC}_{50} \mathrm{~S}(\mu \mathrm{M})$ for compounds 1-9 and 11 determined from in vitro binding assays for compounds binding to RNA constructs.

Table S6 $\quad \mathrm{EC}_{50} \mathrm{~S}(\mu \mathrm{M})$ determined from 2-AP competitive assays for compounds 4 to 8 binding to DDPAC RNA constructs.

Table S7 $\quad{ }^{1} \mathrm{H}$ NMR chemical shifts of the 5-bound WT stem mimic complex.

Table S8 $\quad{ }^{1} \mathrm{H}$ NMR chemical shifts of the 9-bound WT stem mimic complex.

Table S9 NOE restraints used for modeling of unbound stem mimic duplex.

Table S10 NOE restraints used for modeling of stem mimic duplex bound to 4 (denoted by F5D).

Table S11 NOE restraints used for modeling of stem mimic duplex bound to $\mathbf{5}$ (denoted by PFA).

Table S12 NOE restraints used for modeling of stem mimic duplex bound to 9 (denoted by PFB). 
Table S13 Forward primers of microRNAs containing A-bulge sites in the same sequence context as in the tau exon 10 hairpin.

Table S14 Primers for RT-qPCR and Chem-CLIP. 86

$\begin{array}{ll}\text { References } & 87\end{array}$ 


\section{Supplementary Results}

1D NMR spectra of exchangeable protons of unbound and 4-bound RNAs. WaterLOGSY spectra of 4 bound to WT and DDPAC stem mimic duplexes indicate solubility of the compound in the presence of RNA (Figure S18). Therefore, 1D and 2D ${ }^{1} \mathrm{H}$ NMR spectra focused on the exchangeable imino region were collected and analyzed for WT and DDPAC stem mimic duplexes containing an adenine bulge with increasing concentrations of compounds (the results are summarized in Table S1). For each construct, 2D NOESY spectra were used to assign imino proton resonances via imino proton walks and $\mathrm{AH} 2$ to $\mathrm{UH} 3$ or $\mathrm{C}$ amino to $\mathrm{GH} 1$ cross-peaks within base pairs (Figures S19 and S20). In Figure S21 (panel B), NMR titrations of the WT stem mimic duplex with $\mathbf{4}$ are shown. In the spectra of the WT stem mimic with $\mathbf{4}$, a set of resonances appear, representing the bound 4:RNA complex. For the WT stem mimic, both the bound and unbound resonances are still present at a 2:1 ratio of 4 to RNA. When the ratio of 4 to RNA exceeded 2:1, the complex precipitated. Therefore, complete binding of 4 at a $1: 1$ stoichiometry was not possible. In spectra with $\mathbf{4}$, the imino proton resonances corresponding to U18 and G4 of the bound RNA show upfield shifts while U8 is shifted slightly downfield and broadens. This suggests a possible stabilization of the nucleotides adjacent to the binding site associated with better stacking interactions and/or the possibility of the displaced adenine shielding the U8 imino from exchange with the solvent. ${ }^{1}$ The U10 imino proton exhibits slight line narrowing when compared to the imino resonances closer to the adenine bulge, but remains relatively unchanged in the presence of 4 . The G3 imino resonance appears to split with increasing concentrations of 4. The $\mathrm{G} 17$ and the $\mathrm{G} 7$ imino protons that flank the adenine exhibit significant line broadening with no apparent resonance corresponding to the bound states observed in the 1D spectra with 4. The observed broadening of $\mathrm{G} 7$ and G17 could be from solvent exchange in the bound conformations, from the displacement of adenine and the binding of $\mathbf{4}$, or from conformational exchange of $\mathbf{4}$ in the active site. The broadening can also be associated the equilibrium between the bound and unbound states with an intermediate exchange rate on the NMR timescale. The presence of two distinct peaks for some of the imino protons with observed exchange cross-peaks in the 2D NOESY spectrum (Figure S22) is consistent with tight binding between $\mathbf{4}$ and the RNA, which yields a long-lived bound state and slow exchange between the bound and free states. ${ }^{2-3}$ The observed exchange cross-peaks are consistent with exchange between the bound and free states at a rate slower than that of the NMR time scale.

Titrating 4 into the DDPAC Tau stem mimic duplex yielded significant changes in the spectra of the RNA (Figure S21, panel C). In 1D spectra of the RNA titrated with 4, a second set of resonances appear that correspond to the 4:RNA complex. As with the WT Tau duplex, resonances for U18 and G4 of the 4-bound RNA appear upfield of those of the unbound RNA. The U8, U10, and G21 resonances shift slightly downfield, but U10 resonance sharpens while U8 and G21 broaden, which are also consistent with the titration of the WT Tau duplex. These results clearly indicate compound binding. Such an observation has been previously reported by the Varani group in structural studies of the full-length hairpin construct. ${ }^{4}$ From the observed NMR spectra, the C-to- $U$ substitution results in destabilization of the duplex that increases exchange with the bulk water. In particular, the G4 and G9 imino proton resonances broaden in the DDPAC construct but sharpen in the WT construct from 2 to $30{ }^{\circ} \mathrm{C}$ (Figure S23). Similarly, the same resonances in the 4-bound DDPAC construct broaden from 2 to $30^{\circ} \mathrm{C}$, whereas $\mathrm{G} 9$ sharpens and a bound conformation resonance of G4 appears in the WT construct from 2 to $30^{\circ} \mathrm{C}$ (Figure S24). This is consistent with broadening of imino proton resonances and unfolding of the DDPAC Tau hairpin construct observed at $35^{\circ} \mathrm{C}$ by Varani et al. under NMR conditions, while imino proton resonances of the WT Tau hairpin construct remained sharp and distinct. ${ }^{5}$ Varani et al. confirmed the destabilization of the stem by the C-to-U mutation using UV spectroscopy. ${ }^{5}$

2D NMR spectra of exchangeable and nonexchangeable protons of unbound RNAs. Imino proton chemical shifts and intensities suggest that all bases in the WT and DDPAC duplexes 
are WC paired. Through space interproton distances, typically $<5 \AA$, can be derived from NOEs cross-peaks observed in 2D NOESY spectra, thus providing key structural and dynamic information. In the case of the unbound WT and DDPAC hairpins, sequential $\mathrm{H} 1$ ' to $\mathrm{H6} / \mathrm{H} 8 \mathrm{NOE}$ connectivities for both strands of the duplexes are observed (Figures S25 and S26), with the exception of the $\mathrm{U} 14 \mathrm{H} 6-\mathrm{A} 13 \mathrm{H} 1$ ' connectivity in the spectrum of the DDPAC duplex. The presence of NOEs between the $\mathrm{H}^{\prime}$ ' and $\mathrm{H} 2$ ' of $\mathrm{C} 5$ to $\mathrm{A} 6 \mathrm{H} 8$ and $\mathrm{A} 6 \mathrm{H} 1$ ' to $\mathrm{G} 7 \mathrm{H} 8$ indicate that the $\mathrm{A} 6$ bulge stacks within the helices and NOEs from H1', H2', and H3' of $\mathrm{C} 16$ to $\mathrm{G} 17 \mathrm{H} 8$ indicate that $\mathrm{C} 16$ and G17 are in close proximity to each other. NOEs characteristic of A-form RNA in the stem were also observed from $\mathrm{A} 13 \mathrm{H} 2$ to $\mathrm{C} 14 \mathrm{H} 1$ ' and $\mathrm{G} 11 \mathrm{H} 1$ ' and $\mathrm{A} 15 \mathrm{H} 2$ to $\mathrm{C} 16 \mathrm{H} 1$ ' and $\mathrm{G} 9 \mathrm{H} 1$ '. These NOEs indicate that the unbound stem mimic duplexes adopt predominantly A-form helices with the A6 base stacked between C5 and G7. The assigned chemical shift values for all but the changed nucleotides were similar for the WT and DDPAC constructs (Tables S2 and S3). However, $\mathrm{A} 13 \mathrm{H} 8$ is shifted upfield and $\mathrm{A} 15 \mathrm{H} 8$ is shifted downfield by 0.14 and $0.33 \mathrm{ppm}$, respectively, in the DDPAC construct relative to the WT construct. Additional cross-peaks corresponding to a minor conformation of the DDPAC duplex are present in the spectrum of the duplex but were not assigned due to limited spectral data. Altogether, these data show that the WT and DDPAC stem mimic duplexes form similar structures that consist of stable duplexes with A6 stacked between Watson-Crick GC pairs, but that the WT duplex is more conformationally stable.

2D NMR spectra of nonexchangeable protons of 4-bound WT RNA. Addition of 4 to the WT Tau RNA in a 1:1 4/RNA ratio resulted in broadening and shifting of resonances in 2D NOESY spectra (Figure S27 and Table S4). The NOESY walk for residues C1-G11 is disrupted at the $\mathrm{A} 6$ bulge, with $\mathrm{G} 5 \mathrm{H} 1$ ' to $\mathrm{A} 6 \mathrm{H} 8$ and $\mathrm{A} 6 \mathrm{H} 1$ ' to $\mathrm{G} 7 \mathrm{H} 8$ steps not observed, indicating that the A6 base is no longer stacked and is most likely externally oriented when $\mathbf{4}$ is bound. On the opposite strand, the $\mathrm{C} 16 \mathrm{H} 1^{\prime}$ and $\mathrm{C} 16 \mathrm{H} 2$ ' to $\mathrm{G} 17 \mathrm{H} 8$ NOEs across the A6 bulge are observed, suggesting that 4 intercalates such that $\mathrm{C} 16$ and G17 still exhibit NOEs to each other. In the 2D NOESY spectrum, resonances corresponding to both the bound and unbound structures were observed. These involved the G4-U18 base pair, A6 bulge, and nucleotides C5, G7, U8, C16, $\mathrm{G} 17$, and $\mathrm{U} 18$. The presence of multiple resonances indicates a slow equilibrium between bound and unbound states and is consistent with the observed imino proton titration spectra. Increasing the ratio of $4: W T$ tau above $1: 1$ in the $700 \mu \mathrm{M}$ RNA sample resulted in aggregation and precipitation of the sample. Therefore, a fully bound 4:WT tau complex could not be achieved at NMR concentrations.

Analysis of NOESY spectra at mixing times of 400 and $100 \mathrm{~ms}$ for the $1: 14:$ WT Tau RNA complex provided distance restraints. For the bound structure, the $\mathrm{H} 1$ ', $\mathrm{H} 6$ or $\mathrm{H} 8$, and $\mathrm{H} 5$ resonances of G4, U18, and C19 exhibited upfield shifts, indicating possible changes in base stacking interactions and ring current effects by binding of $\mathbf{4}$ or displacement of the adenine. ${ }^{1}$ There were a number of exchange cross-peaks observed in the base to $\mathrm{H} 1$ ' region of the NOESY spectrum (Figure S27). Exchange peaks for H5-H6 cross-peaks for $\mathrm{C} 5$ and $\mathrm{C} 16$, which flank 4, exhibit exchange peaks, designated as $\mathrm{C} 5-\mathrm{C}^{\dagger}$ and $\mathrm{C} 16-\mathrm{C} 16^{\dagger}$, respectively in Figure S27, represent slow exchange between the bound and unbound conformations. This is supported by the presence of exchange cross peaks corresponding to the imino protons of the G4-U18 wobble base pair (Figure S22) and intermolecular NOEs observed from $\mathrm{H} 4$ of 4 to $\mathrm{C}^{16 \mathrm{H} 1}$ ' and $\mathrm{C} 16 \mathrm{H} 2$ '. These NOEs position 4 within the A6 bulge loop region. Binding of 4 to this region is further supported by disruption of the NOESY walk at residue A6 and upfield shifts of 4 proton resonances. Additional NOEs from RNA to 4 were observed between $\mathrm{H} 7$ methyl protons of 4 and $\mathrm{C} 5 \mathrm{H} 3{ }^{\prime}, \mathrm{C} 5 \mathrm{H} 5, \mathrm{C} 16 \mathrm{H} 2^{\prime}, \mathrm{A} 6 \mathrm{H} 5{ }^{\prime \prime}$, and $\mathrm{G} 17 \mathrm{H} 1^{\prime}$. These NOEs indicate that the aromatic ring is intercalated with the amidine groups of 4 in the major groove and the sulfur containing aromatic ring stacked between the $\mathrm{C} 5: \mathrm{G} 17$ and $\mathrm{G} 7: 16$ base pairs. In summary, binding of 4 results in intermolecular NOEs from 4 to the nucleotides flanking the bulged A6. These data, in addition to the loss of connectivity from the base to the $\mathrm{H}_{1}$ ' of nucleotide $\mathrm{A} 6$ in the complex with 4 , indicate 
that compound $\mathbf{4}$ is stacked in the RNA. This is further supported by shifts in resonances and NOEs of residues close to the A-bulge upon ligand binding.

Overall structure of the unbound WT Tau RNA. An ensemble of 20 structures was generated from restrained molecular dynamics using 191 NOE derived distance restraints (Figure S28 and Table S9). The average RMSD for the structures is $1.79 \AA$ (Table 1), indicating good convergence. The WT Tau adopts an A-form conformation with A6 stacking between C5 and G7 (Figure 8A), consistent with the A-bulge in the structure of the full-length WT hairpin. ${ }^{5}$ The average helical rise of the unbound structure is $2.3 \pm 1.0 \AA$, slightly less than average for $A$-form RNA (2.8 $\AA$ ), and the average helical twist is $33.7 \pm 8.4^{\circ}$, similar to that expected for A-form RNA $\left(\sim 32^{\circ}\right){ }^{6}$ The average $\mathrm{C} 1^{\prime}-\mathrm{C} 1^{\prime}$ distances among all base pairs range from 10.3 to $10.8 \AA$, consistent with typical A-form RNA (average of $\sim 10.5 \AA$ ). ${ }^{7}$ In the unbound conformation, the Abulge is stacked in the helix, between $\mathrm{C} 5$ and $\mathrm{G} 7$, consistent with NOESY walk steps through $\mathrm{H} 1{ }^{\prime}$ and $\mathrm{H} 8$ of $\mathrm{A} 6$, in addition to NOEs from $\mathrm{C} 5 \mathrm{H} 2$ ' to $\mathrm{A} 6 \mathrm{H} 8$ and $\mathrm{A} 6 \mathrm{H} 2$ ' to $\mathrm{U} 7 \mathrm{H} 6$. The intensity of the cross-peak between $\mathrm{H}^{\prime}$ ' and $\mathrm{H} 8$ of $\mathrm{A} 6$ is consistent with an anti-conformation. The closing bases form Watson-Crick C5-G17 and G7-C16 base pairs, consistent with the presence of C amino proton to $\mathrm{G}$ imino proton NOEs between these bases (Figure S19). The opposite strand C16 and G17 bases are close enough to form NOE contacts between $\mathrm{H}^{\prime}$ ', H2', and H3' of $\mathrm{C} 16$ and $\mathrm{H} 8$ of G17, resulting in a slight bend in the helix. The helix is overwound at the 5'G4C5/3'U18G17 step, with a helical twist value of $39.9 \pm 2.5^{\circ}$, adjacent to the A-bulge. The G4-U18 wobble pair has a relatively large average propeller twist $\left(-21.5 \pm 3.5^{\circ}\right)$ around the GN1-UN3 bond. Relatively large propeller twists were also observed for the G7-C16 A-bulge closing pair $\left(-17.8 \pm 4.1^{\circ}\right)$, G9-C14 $\left(-17.2 \pm 2.5^{\circ}\right)$, and U10-A13 $\left(-17.5 \pm 2.7^{\circ}\right)$. The distortion of the G4-U18 base pair is also indicated by relatively large values for base pair opening $\left(10.9 \pm 14.2^{\circ}\right)$ and shear $\left(-2.5 \pm 0.3^{\circ}\right)$ compared with the other base pairs in the ensemble. The G3-C19 pair, which is adjacent to the dynamic G4-U18 pair, and the closing G7-C16 pair are buckled more than other base pairs (-9.2 $\pm 4.1^{\circ}$ and $-10.8 \pm 7.2^{\circ}$, respectively). Altogether, incorporation of the A-bulge and G4-U18 wobble base pair into the helix induces sequence-specific distortions throughout the helical structure that may improve stacking of nearby bases and better accommodate the bulged residue. ${ }^{8}$

WaterLOGSY spectra of compounds 5 to 9 . WaterLOGSY spectra of 8 in complex with the RNA constructs indicate insolubility of the 8-RNA complexes. Therefore, $\mathbf{8}$ was not carried forward in further NMR studies. The remaining compounds except for $\mathbf{6}$ showed no aggregation, as evident by signals of opposite phase in WaterLOGSY spectra of unbound compounds relative to those in WaterLOGSY spectra of RNA-compound complexes. WaterLOGSY spectra of compounds $\mathbf{5}$ and $\mathbf{9}$ in the presence of WT and DDPAC stem mimic duplexes indicate binding of the compounds to the RNAs, as shown by negative NOEs with water. ${ }^{9-10}$ However, WaterLOGSY spectra of 7 in the presence of the duplexes does not show binding, which may be attributed to weak binding of the compound to the RNAs. NMR spectra were collected for WT and DDPAC stem duplexes with increasing concentrations of $\mathbf{5}$ to $\mathbf{7}$ and $\mathbf{9}$ to determine the effect of the compounds on RNA structure.

1D NMR spectra of RNAs bound to compounds 5 to 9. NMR spectra was acquired on 5 to 7 and 9 to identify shifts in imino proton resonances associated with compound binding (Figures S34 to S37). In NMR spectra of the WT stem mimic duplex with 5 and 9 (Figures S34 and S37, respectively), one set of resonances was observed, in contrast to spectra of the WT stem mimic with 4. Upfield shifts of imino proton resonances corresponding to $\mathbf{5}$ and $\mathbf{9}$ were observed, while U8 shifts downfield and broadens upon addition of 5, but not 9 . U10 slightly narrows and shifts upfield in the presence of $\mathbf{5}$ or $\mathbf{9}$ and G3 appears not to be affected by either compound, similar to the spectra with 4. Within the base pairs adjacent to the A-bulge, G17 exhibits significant line broadening while $\mathrm{G} 7$ shifts upfield towards the $\mathrm{G} 20$ resonance. Addition of $\mathbf{5}$ or $\mathbf{9}$ to the DDPAC stem mimic duplex resulted in significant changes to the imino protons. Similar to spectra of the WT stem mimic duplex, one set of resonances remained upon addition 
of $\mathbf{5}$ or $\mathbf{9}$, but the $\mathrm{U} 10$ and $\mathrm{G} 17$ resonances shift upfield and broaden while $\mathrm{G} 7$ and U8 shift downfield. Upfield of these resonances and within the 10 to $12.5 \mathrm{ppm}$ range, G4, U14, and U18 shift slightly upfield and broaden, while G9 remains relatively sharp. Altogether, these spectra indicate that 5 and 9 bind to and alter the structure of the RNA constructs. The single set of resonances between $\mathbf{5}$ and $\mathbf{9}$ and the RNAs may indicate rapid interconversion between the bound and unbound states.

One-dimensional spectra of 7 with WT tau RNA shows that G7 broadens while G17 and U18 broaden and shifts slightly downfield and G21 sharpens (Figure S36). In 1D spectra with 6, G17 shifts downfield while G7 shifts upfield (Figure S35). Compared with titration spectra with the WT construct, the compounds had greater effect on RNA resonances in titration spectra with the DDPAC construct. In 1D spectra of 7 with DDPAC tau RNA, U8 and G17 shift downfield and broaden slightly while U18 and G4/U14 shift slightly upfield and the G7/G20 and U10 resonances broaden. Similar patterns were observed for the U8 and G17 resonances in spectra of compound 6, while U18 shifts downfield. Taken together, these results show that compounds $\mathbf{6}$ to $\mathbf{7}$ bind to the WT and DDPAC constructs.

2D NMR spectra of nonexchangeable protons of 5- and 9-bound RNAs. Resonances for the WT Tau RNA remained sharp at $25^{\circ} \mathrm{C}$ and $35^{\circ} \mathrm{C}$ upon addition of $\mathbf{5}$ or $\mathbf{9}$ in a 1.5:1 compound:RNA ratio (Figures S38 and S39 and Tables S7 and S8). In $400 \mathrm{~ms}$ mixing time spectra, NOESY walks through residues $\mathrm{C} 1-\mathrm{G} 11$ and $\mathrm{C} 12-\mathrm{G} 21$ remained, but NOEs from A6H8 to $\mathrm{C} 5 \mathrm{H} 2$ ' and $\mathrm{G} 7 \mathrm{H} 8$ to $\mathrm{A} 6 \mathrm{H} 2^{\prime}$ were weaker than other NOEs between $\mathrm{H} 6 / \mathrm{H} 8$ and $\mathrm{H} 2{ }^{\prime}$ of the $5^{\prime}$ residue. However, the NOEs between $\mathrm{G} 17 \mathrm{H} 8$ and $\mathrm{C} 16 \mathrm{H} 2$ ' remained strong. These data suggest that the $\mathrm{A} 6$ bulge was displaced from but remained close to the helix upon binding of $\mathbf{5}$ or $\mathbf{9}$ and that residues $\mathrm{C} 16$ and $\mathrm{G} 17$ remained stacked. In contrast to spectra of $\mathbf{4}$ in complex with the Tau RNA, a single set of resonances was observed for the RNA residues, consistent with saturation of binding at the 1.5:1 5:RNA or 9:RNA ratio. In the Tau RNA-9 spectra, NOEs were observed from the $\mathrm{H} 1$ and $\mathrm{H} 2$ aromatic protons of 9 to $\mathrm{G} 17 \mathrm{H} 1$ ' and from $\mathrm{H} 1$ of 9 to $\mathrm{C} 16 \mathrm{H} 2$ '. Intermolecular NOEs were observed from the $\mathrm{H} 1$ quinoline aromatic proton of 5 to $\mathrm{C} 5 \mathrm{H} 2$ ' and from the $\mathrm{H} 4$ and $\mathrm{H} 8$ methoxybenzene aromatic protons of $\mathbf{5}$ to $\mathrm{C} 16 \mathrm{H} 2$ '. These NOEs suggest that $\mathbf{5}$ and $\mathbf{9}$ are stacked in the A6 bulge region. The NOEs between the 9 aromatic protons and Tau RNA position the aromatic ring of $\mathbf{9}$ containing the methoxy group close to the opposite strand of the A-bulge. The NOEs between the $\mathbf{5}$ aromatic protons and Tau RNA position the quinoline of $\mathbf{5}$ close to the strand containing the A-bulge and the methoxybenzene group of 5 close to the opposite strand. NOEs from overlapped $\mathrm{H} 5$ and/or $\mathrm{H} 6$ protons of 5 to $\mathrm{C} 16 \mathrm{H} 2$ ' and $\mathrm{G} 17 \mathrm{H} 1$ ' could not be conclusively assigned and NOEs from $\mathrm{H} 4$ and $\mathrm{H} 8$ protons of 5 to $\mathrm{G} 17 \mathrm{H} 1$ ' were weak. Therefore, these NOEs were not applied as distance restraints. In the Tau RNA-9 spectra, NOEs were observed between the $\mathrm{C} 7$ methyl group of 9 and $\mathrm{A} 6 \mathrm{H} 1^{\prime}, \mathrm{G} 7 \mathrm{H} 8, \mathrm{C} 16 \mathrm{H} 5, \mathrm{G} 17 \mathrm{H} 1^{\prime}$, and $\mathrm{G} 17 \mathrm{H} 8$. Additional NOEs were observed between the $\mathrm{C} 7$ methyl group of 5 and $\mathrm{C} 5 \mathrm{H} 1$ ', $\mathrm{C} 5 \mathrm{H} 2$ ', G7H1', C16H2', G17H1', and G17H8. These NOEs position the methoxy group of $\mathbf{9}$ and methyl group of the $\mathbf{5}$ quinoline between the closing base pairs of the A6 bulge. A separate NOE was observed between the C16 methyl group of 9 and $\mathrm{G} 7 \mathrm{H} 8$, which positions the tertiary amine of $\mathbf{9}$ close to the strand containing the A6-bulge. 


\section{Supplementary Figures}<smiles>N=C(N)c1ccc(Nc2ccc(C(=N)N)cc2)cc1</smiles>

S1<smiles>Cc1ccc(-c2cc3ccccc3[nH]2)cc1</smiles>

S2<smiles>N=C(N)c1ccc2[nH]c3c(c2c1)CCC3</smiles>

S3

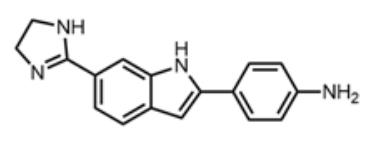

S4<smiles>N#Cc1ccc(/C=N/NC(=N)N)cc1</smiles>

S5<smiles>N=C(N)N/N=C/c1cccs1</smiles>

s6<smiles>CN(C)c1ccc(/C=C/c2sc3ccccc3[n+]2C)cc1</smiles>

S7<smiles>N=C(NC(=N)c1ccc(C(=N)N)cc1)Nc1ccc(C(=N)N)cc1</smiles><smiles>N=C(N)NN=Cc1ccc(C=NNC(=N)N)cc1</smiles><smiles></smiles>

S11<smiles>C/C(NC(=N)N)=C(\Cc1ccccc1)NC(=N)N</smiles>

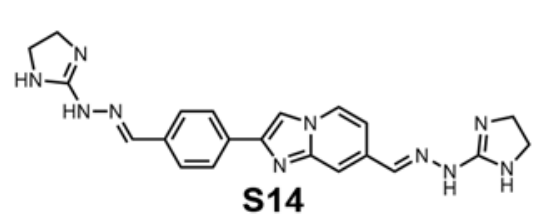<smiles>O=S(=O)(Nc1cccc(C2NCCN2)c1)c1ccc(Oc2ccc(S(=O)(=O)Nc3cccc(C4NCCN4)c3)cc2)cc1</smiles><smiles>Nc1nc(Nc2ccc(C3=NCCN3)cc2)nc(Nc2ccc(C3=NCCN3)cc2)n1</smiles><smiles>N=C(N)c1ccc(Nc2ccc(-c3cc4ccc(C(=N)N)cc4[nH]3)cc2)cc1</smiles><smiles>N=C(N)c1ccc(Oc2ccc(-c3cc4ccc(C(N)N)cc4[nH]3)cc2)cc1</smiles><smiles></smiles><smiles>CNC(=N)N/N=C(\C)c1ccc2sc3ccc(/C(C)=N/NC(=N)NC)cc3c2c1</smiles>

Figure S1: Set of 20 compounds identified by Inforna and screened in cell-based luciferase assay. Pharmacophore models were then constructed using LigandScout with 16 inactive (S1 to S16) and four active (1 to 4 ) compounds in the training set. 


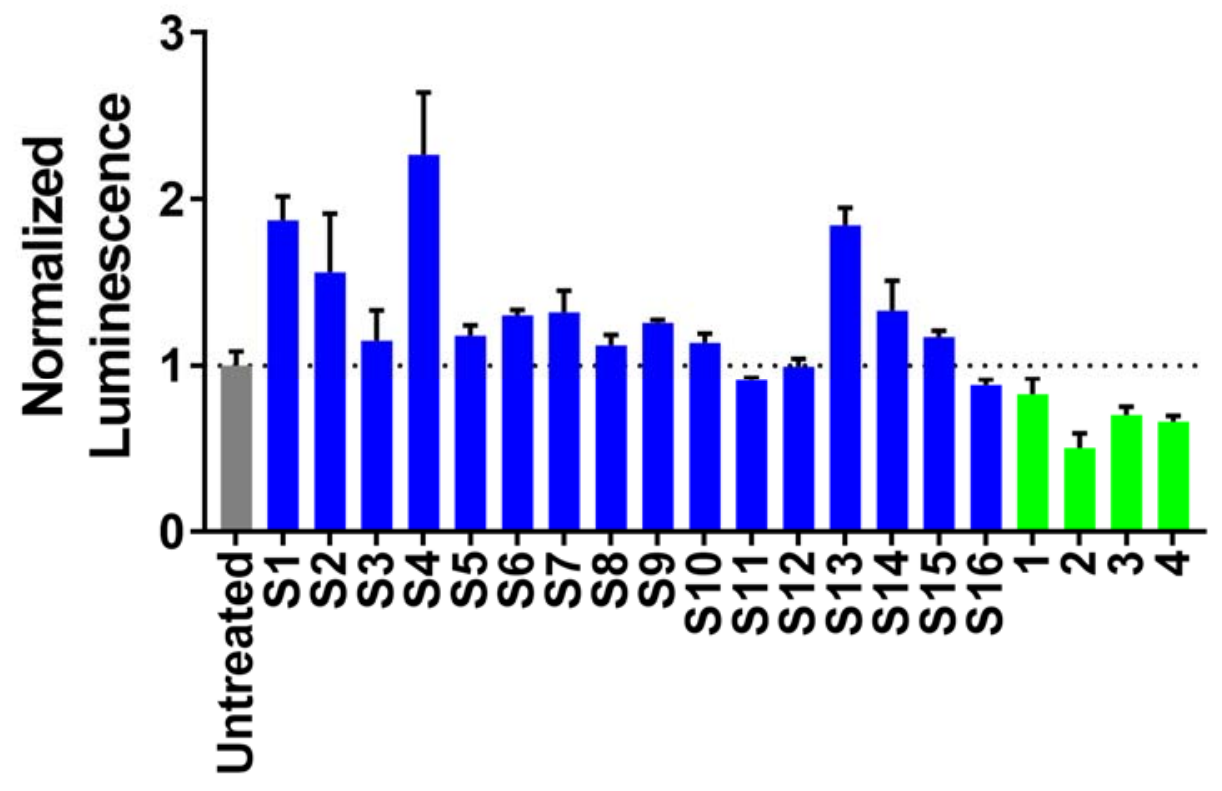

Figure S2: The effect of Inforna-derived compounds on expression of luciferase in cellbased assays. All compounds were tested at $20 \mu \mathrm{M}$ final concentration except for S13 (which was tested at $15 \mu \mathrm{M}$ ). Compounds were tested in HeLa cells transfected with a DDPAC luciferase reporter gene. Error bars indicate SD. 


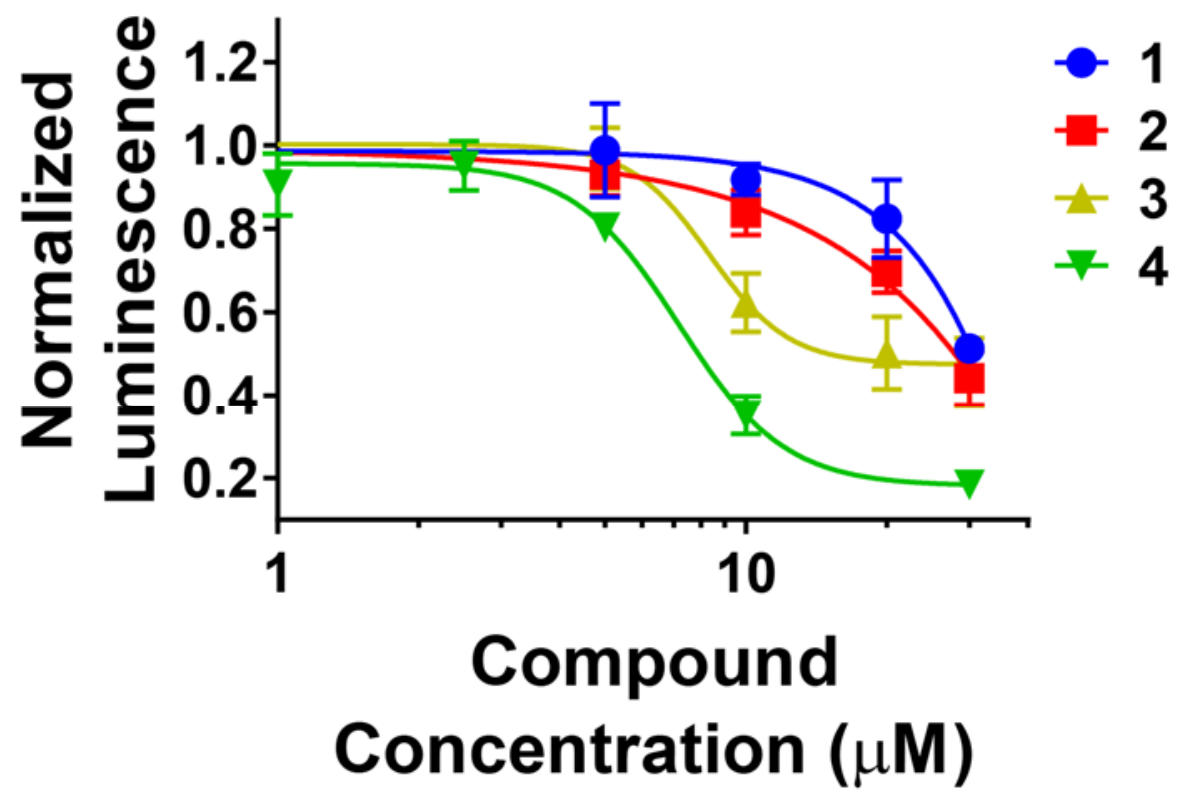

Figure S3: The effect of Inforna-derived compounds 1 to 4 on expression of luciferase in cell-based assays. HeLa cells transfected with a DDPAC construct and treated with compounds at 5, 10, 20 and $30 \mu \mathrm{M}$ for 1 to 3 and at 1, 2.5, 5, 10, and $30 \mu \mathrm{M}$ for 4 . Error bars indicate SD. 


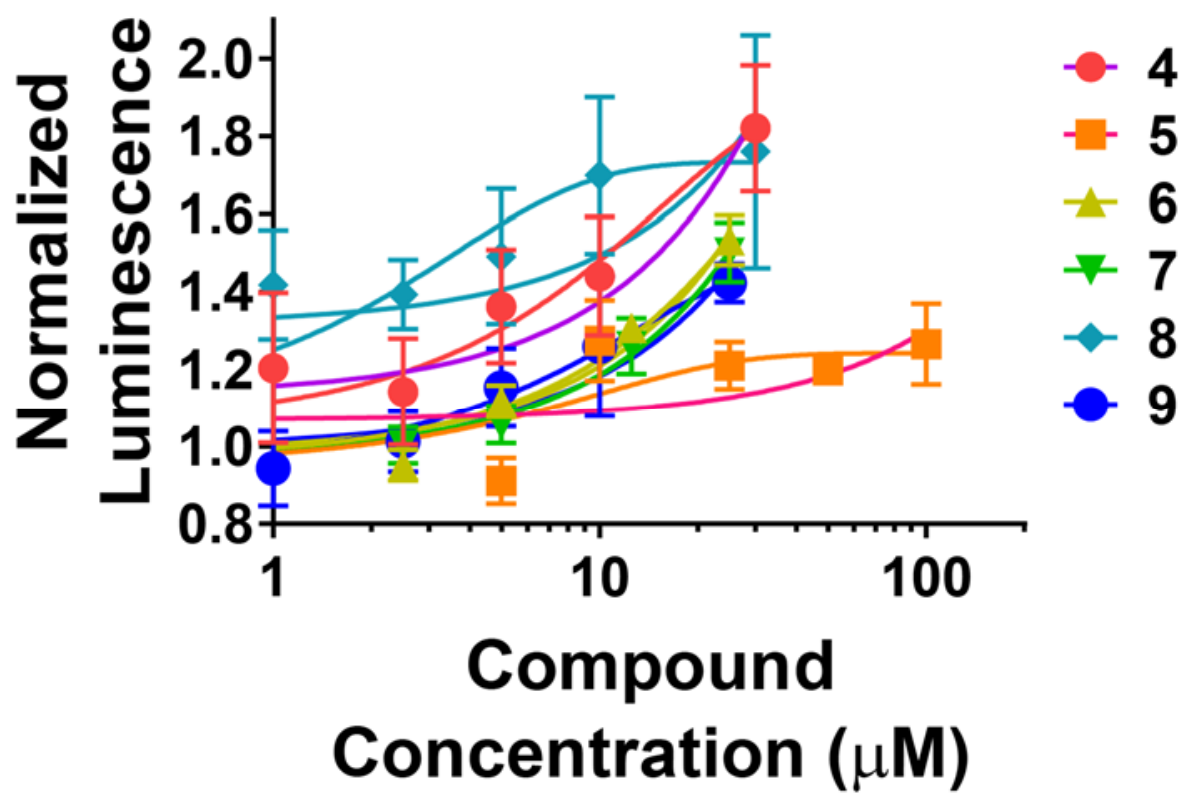

Figure S4: The effect of compounds 4 to 9 on expression of luciferase in BE(2)-M17 cells stably transfected with a minigene expressing DDPAC Tau. Error bars indicate SD. 
A

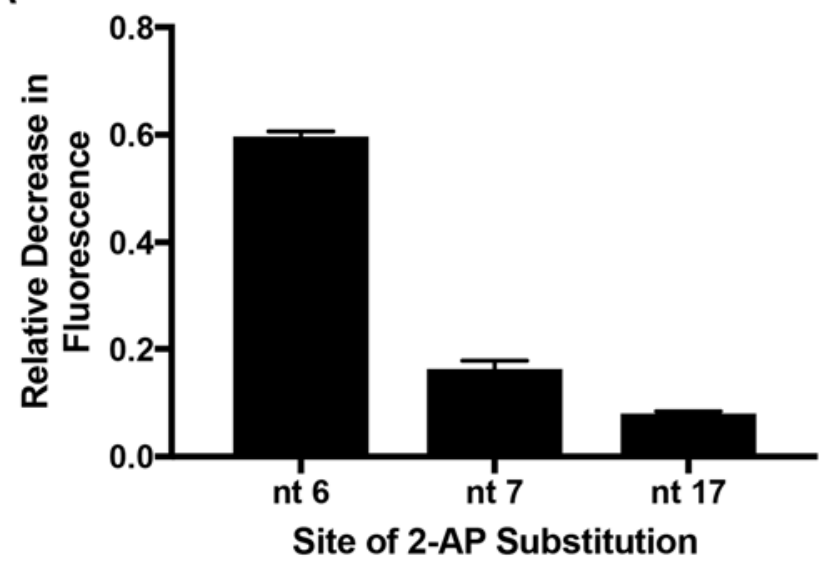

B

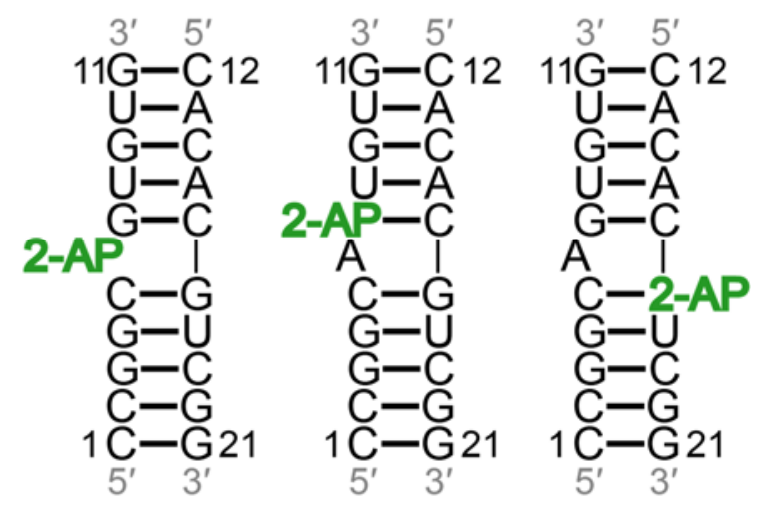

Figure S5: The effect of 2-AP substitutions at different sites of the WT duplex on fluorescence induced by binding of 4 . (A) Fluorescence intensity of RNAs bound to 4 relative to unbound RNAs. (B) Secondary structures of the constructs with 2-AP substitutions at nucleotides 6 (left), 7 (middle), and 17 (right). These data show that 4 has the greatest effect on the conformation of the base at the A-bulge site. Error bars indicate SD. 
A

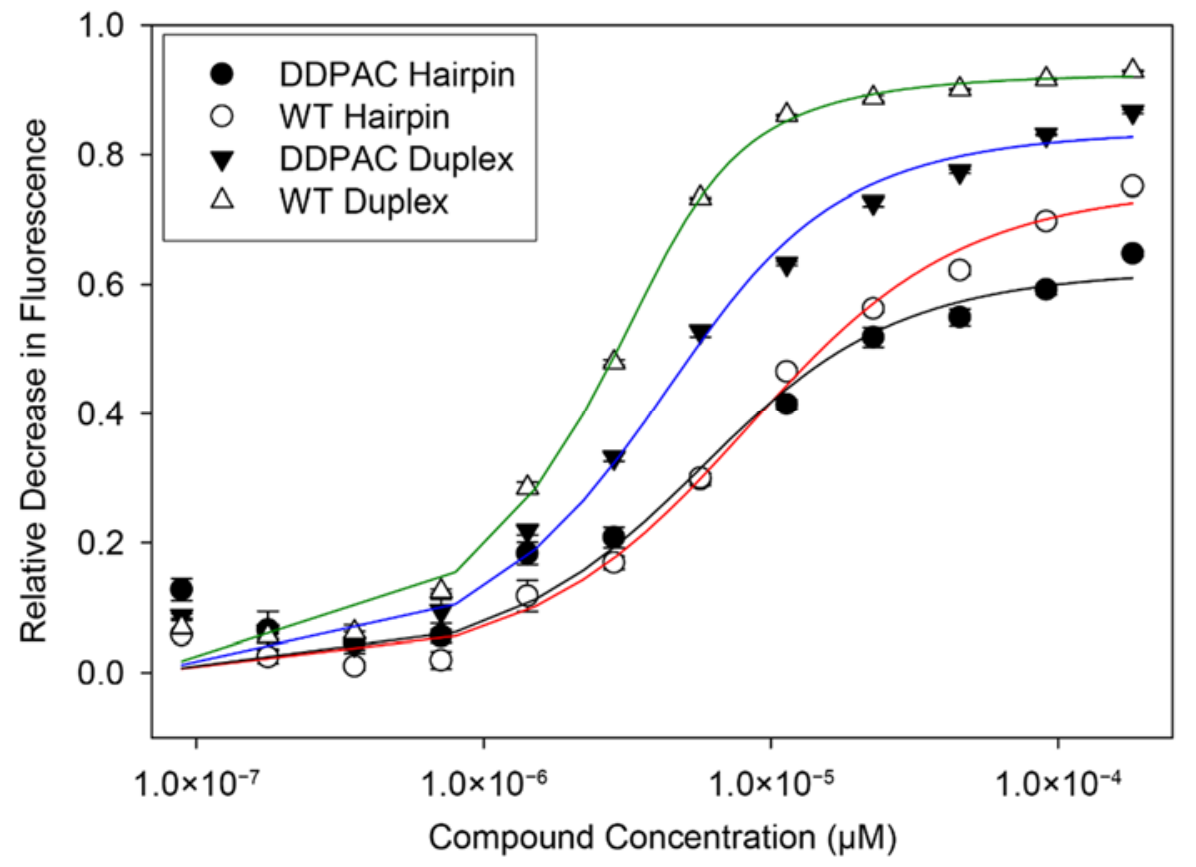

B

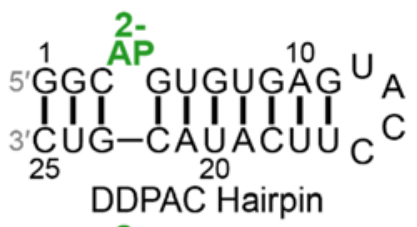

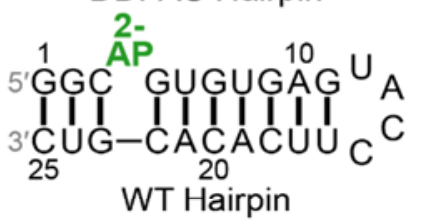

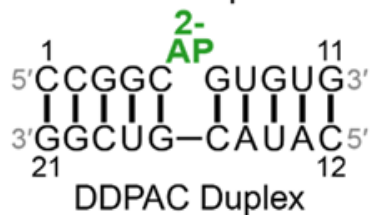

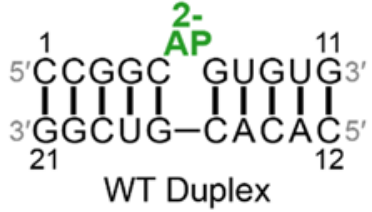

Figure S6: Binding assays of 4 and hairpin and duplex constructs used in this study. (A) Binding curves for 4 and DDPAC and WT constructs. $K_{d}$ values of full length and minimized constructs are relatively close to each other: DDPAC hairpin, $3.59 \pm 1.19 \mu \mathrm{M}$; WT hairpin, $6.21 \pm$ $0.80 \mu \mathrm{M}$; DDPAC duplex, $2.07 \pm 0.41 \mu \mathrm{M}$; WT duplex, $0.65 \pm 0.10 \mu \mathrm{M}$. DDPAC and WT duplex constructs were used in NMR studies. (B) Secondary structures of DDPAC and WT constructs. Error bars indicate SD. 


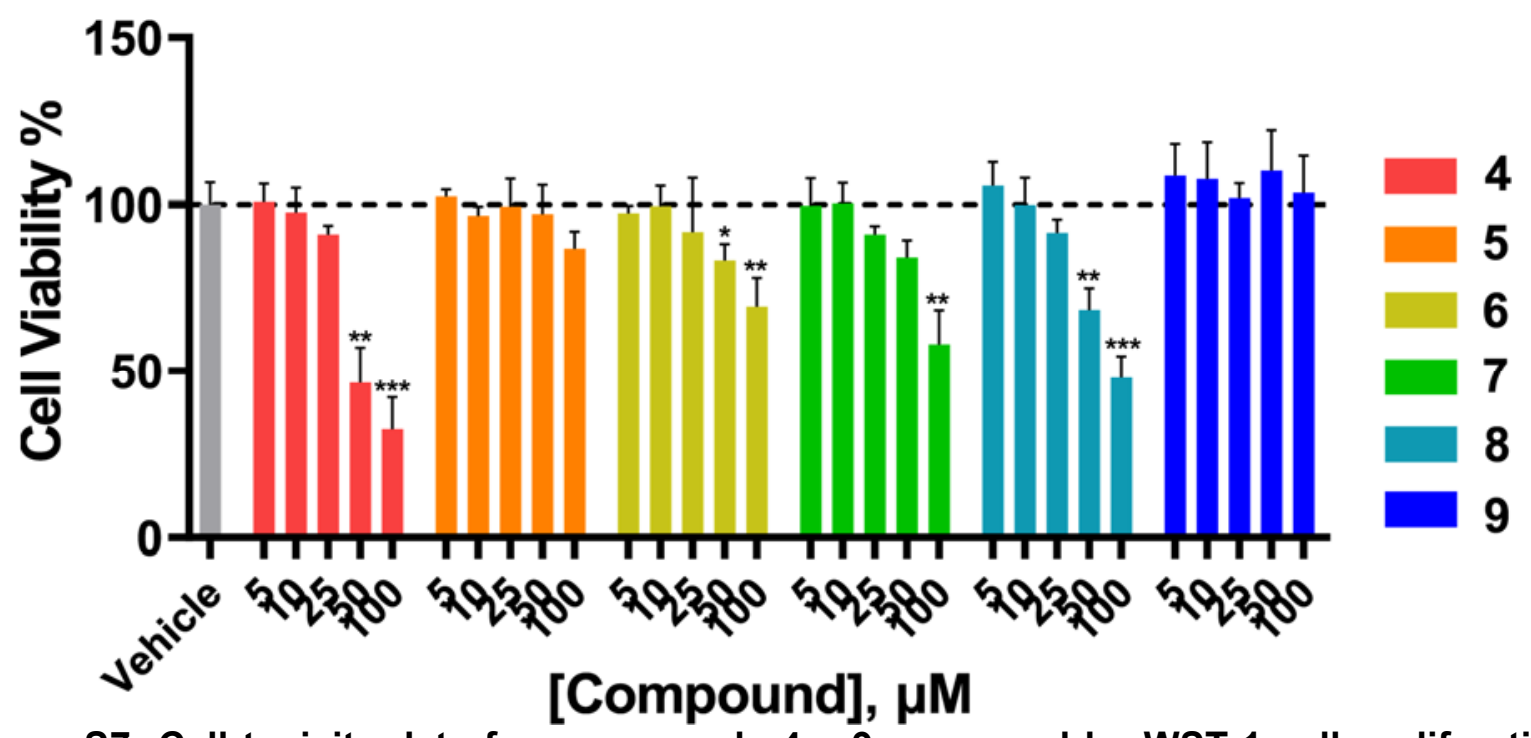

Figure S7: Cell toxicity data for compounds $4-9$, assessed by WST-1 cell proliferation reagent. Error bars indicate $S D$. ${ }^{*} P<0.05$, ${ }^{* *} P<0.01$, and ${ }^{* * *} P<0.001$ as determined by a two-tailed Student t-test. 
A

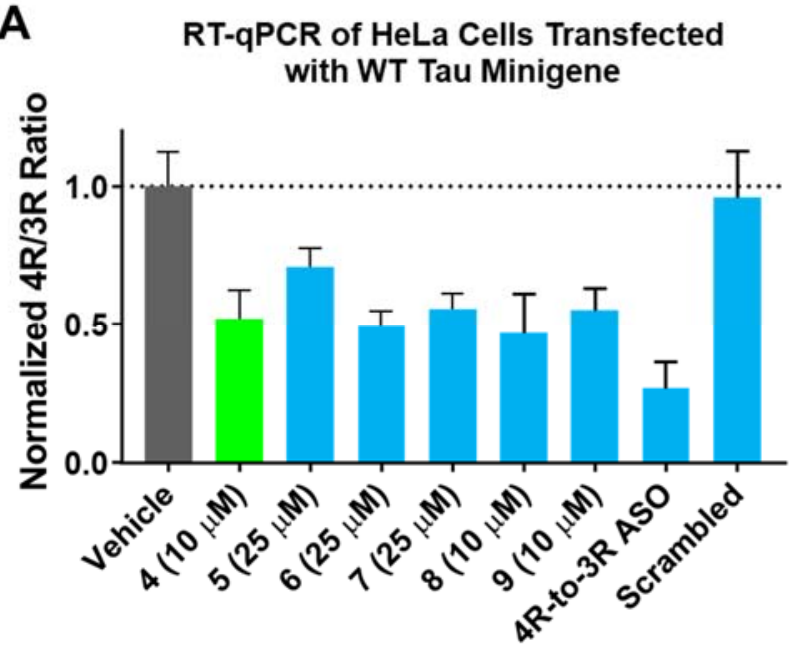

C

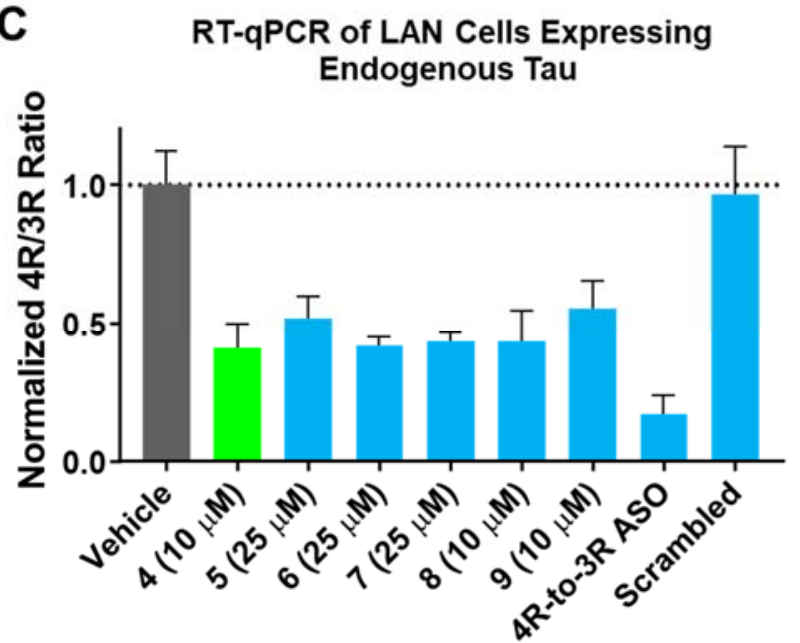

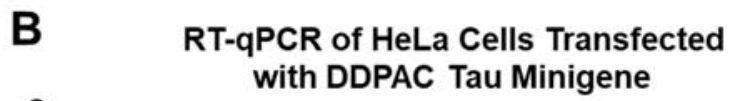

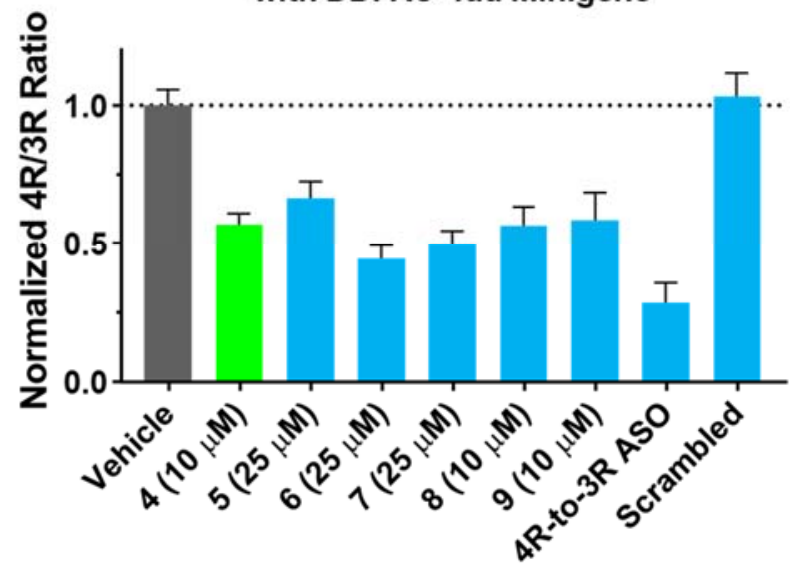

D RT-qPCR of HeLa Cells Transfected with DDPAC+I17T Tau Minigene

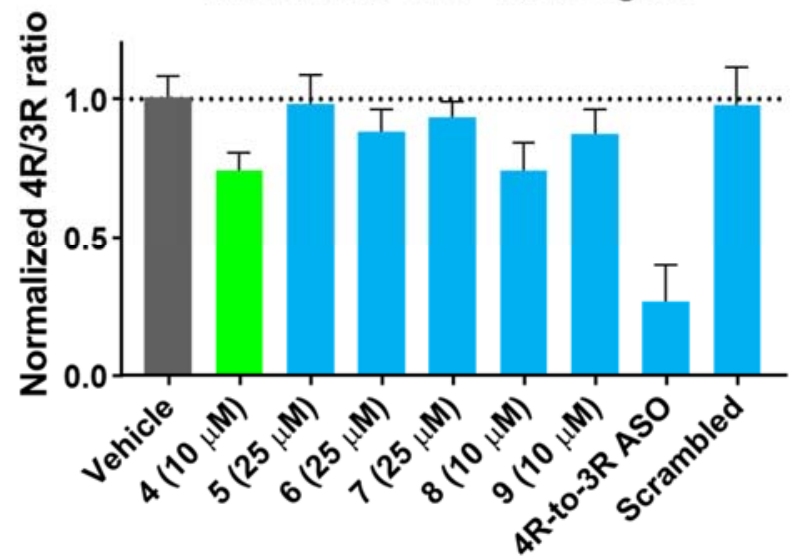

Figure S8: The effect of hit compounds on relative amounts of $4 R$ and $3 R$ Tau mRNA assessed by RT-qPCR. (A) Results of HeLa cells transfected with a WT construct. (B) Results of HeLa cells transfected with a DDPAC construct. (C) Results of LAN5 cells expressing endogenous Tau. (D) Results from HeLa cells transfected with a fully base paired DDPAC hairpin (DDPAC+117T) construct. Error bars indicate SD. 


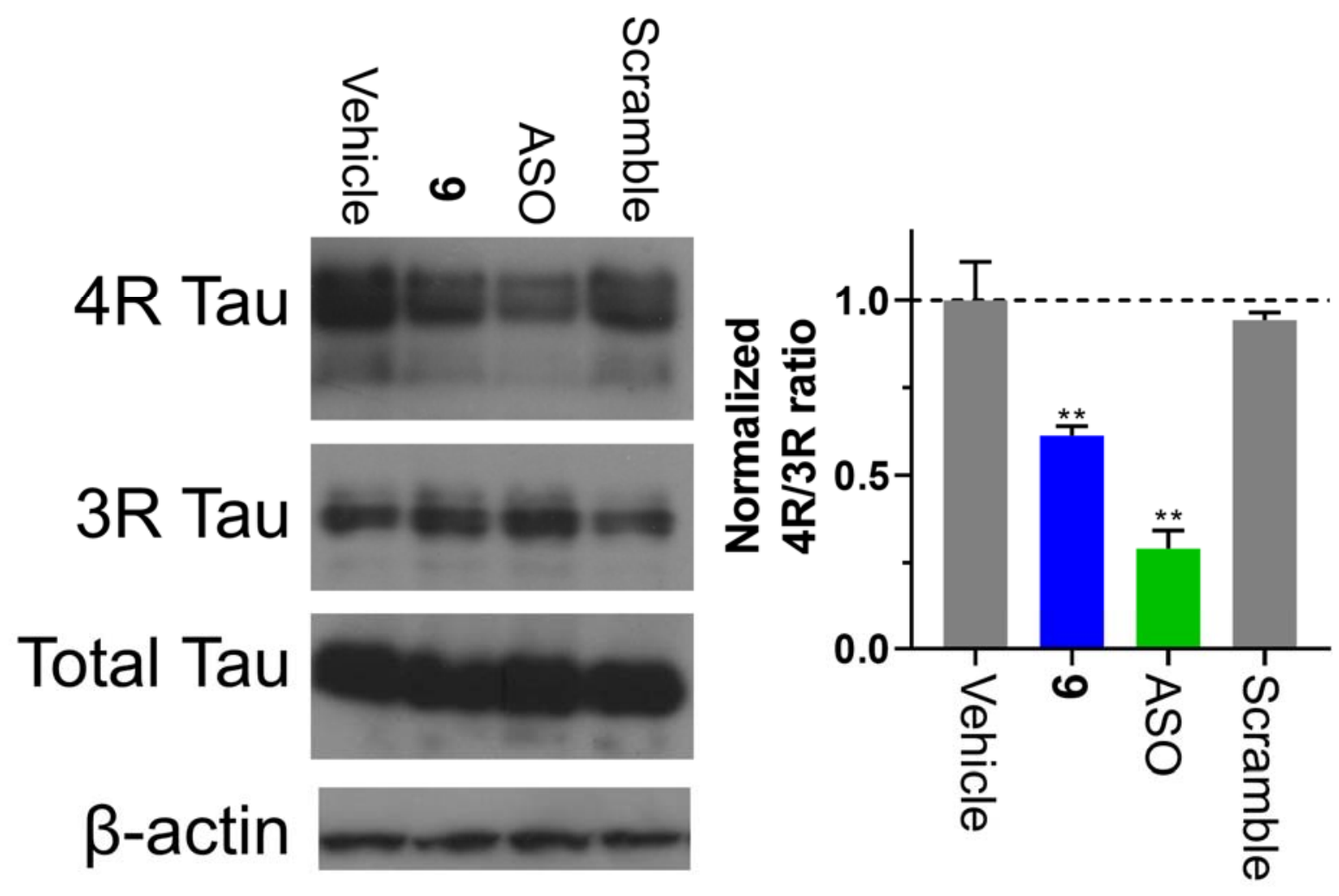

Figure S9: Protein modulation with compound 9 and 4R-to-3R ASO treatment. Representative western blot analysis for $4 \mathrm{R}, 3 \mathrm{R}$ and total Tau proteins with $9(10 \mu \mathrm{M})$ and $4 \mathrm{R}$-to3R ASO $(0.5 \mu \mathrm{M})$ treatment. All panels were done in LAN5 cells. Error bars indicate SD. ${ }^{* *} \mathrm{P}<$ 0.01 as determined by a two-tailed Student t-test. 

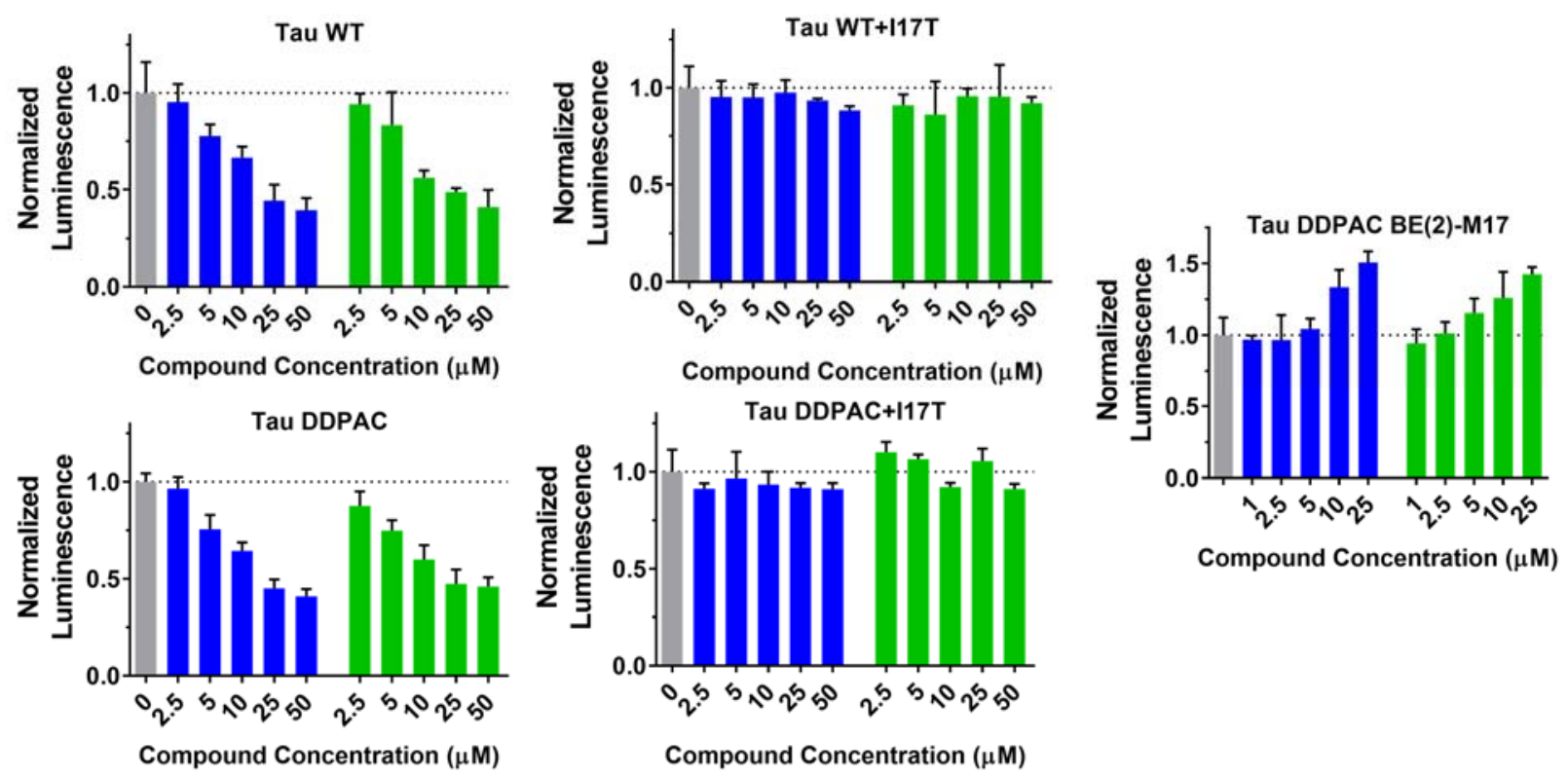

Figure S10: The effect of compounds 9 and 11 on expression of luciferase in HeLa cells transfected with WT, DDPAC, WT+117T, and DDPAC+117T minigenes, and in BE(2)-M17 cells stably transfected with a minigene expressing DDPAC tau. Blue bars correspond to compound 9 and green bars correspond to compound 11. Error bars indicate SD. 

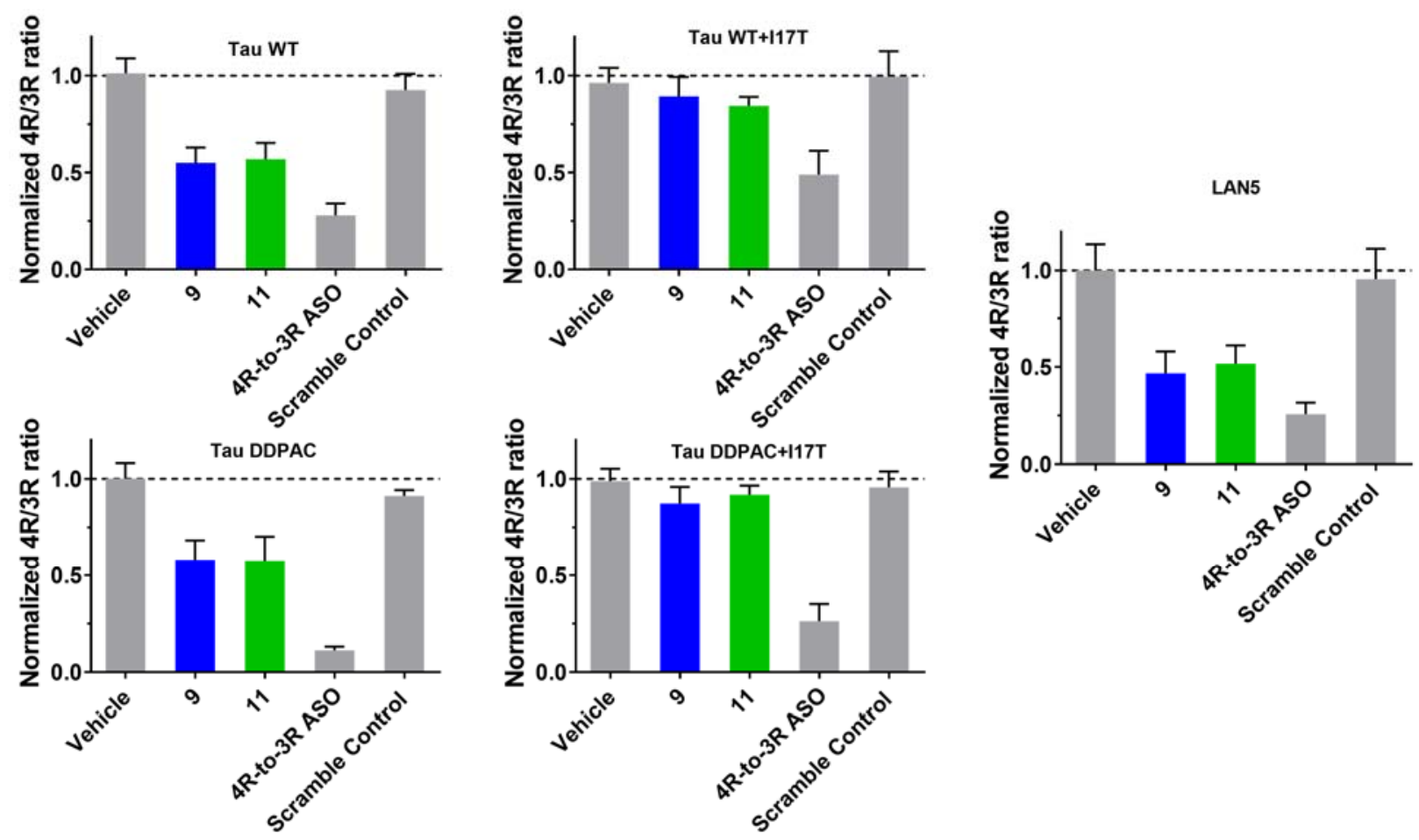

Figure S11: The effect of 11 on relative amounts of $4 R$ and 3R tau pre-mRNA assessed by RT-qPCR in HeLa cells transfected with WT, DDPAC, WT+I17T, and DDPAC+I17T minigenes, and in LAN5 neuroblastoma cells. Cells were treated with $10 \mu \mathrm{M}$ of compound 9 or 11 or $0.5 \mu \mathrm{M}$ of ASO control. Error bars indicate SD. 


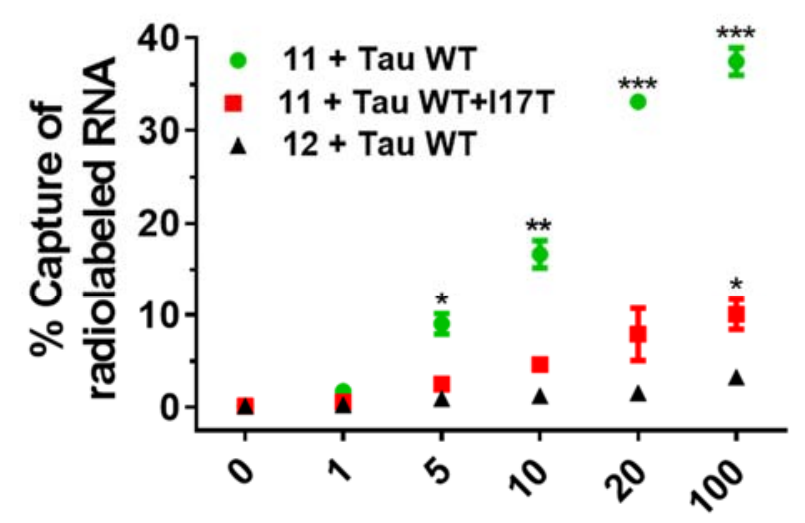

[Compound], $\mu \mathrm{M}$

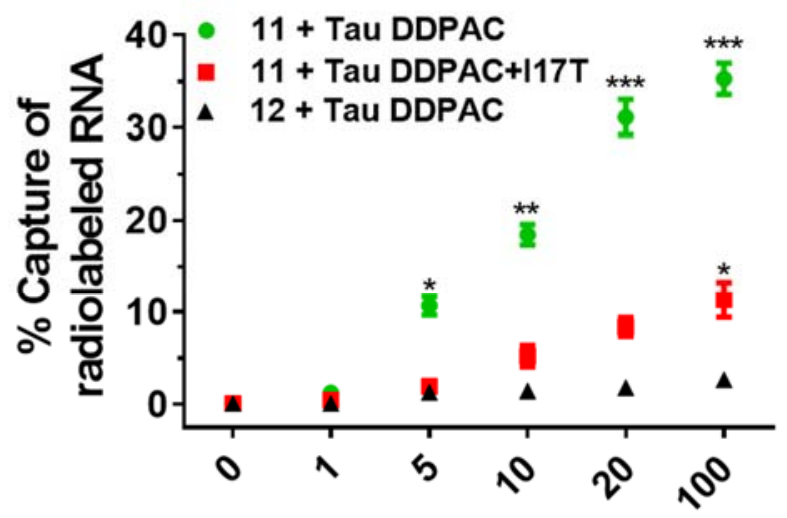

[Compound], $\mu \mathrm{M}$

Figure S12: The effect of increasing concentrations of compounds 11 and 12 on amounts of DDPAC and DDPAC+117T mutant RNAs pulled down in Chem-CLIP experiments. Error bars indicate $S D$. ${ }^{*} P<0.05$, ${ }^{* *} P<0.01$, and ${ }^{* * *} P<0.001$ as determined by a two-tailed Student t-test. 


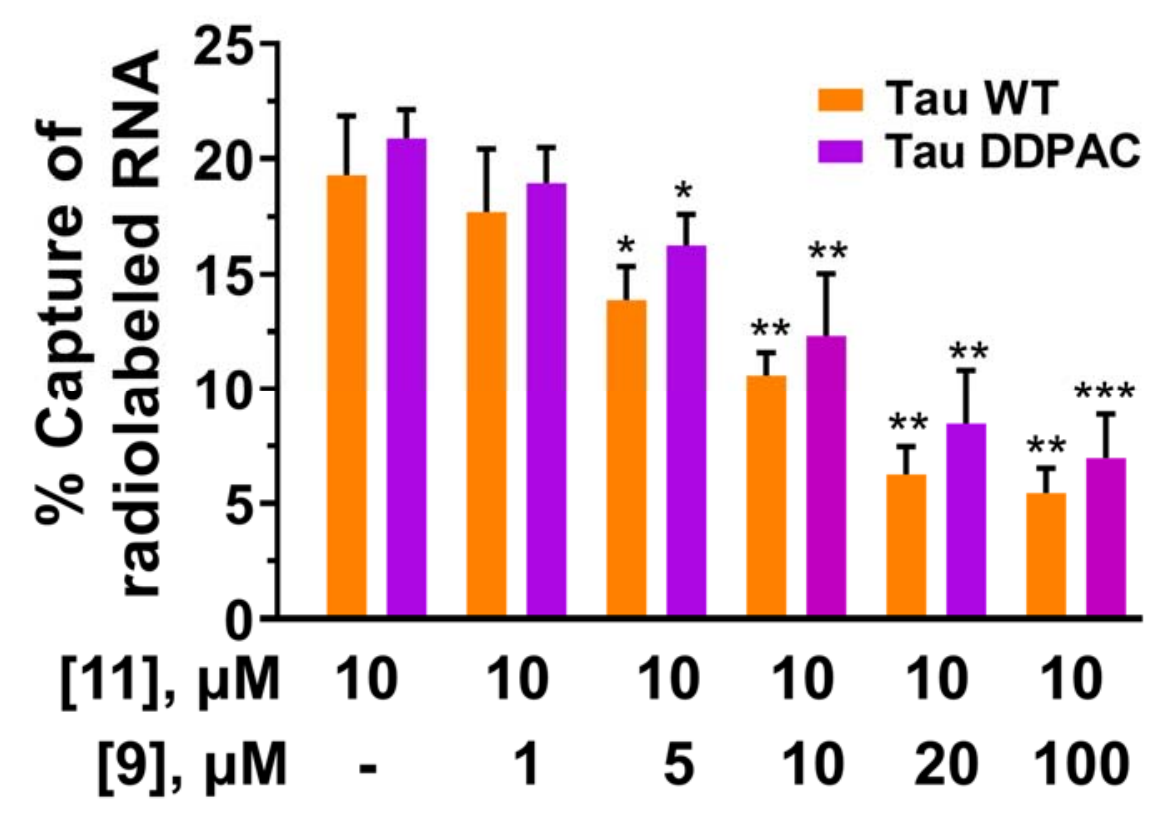

Figure S13: Results of in vitro C-Chem-CLIP experiments with WT and DDPAC RNAs and 9 and 11. Increasing concentrations of 9 inhibits pulldown of RNAs by 11 in a dose-dependent manner. Error bars indicate SD. ${ }^{*} \mathrm{P}<0.05,{ }^{* *} \mathrm{P}<0.01$, and ${ }^{* * *} \mathrm{P}<0.001$ as determined by a two-tailed Student t-test. 


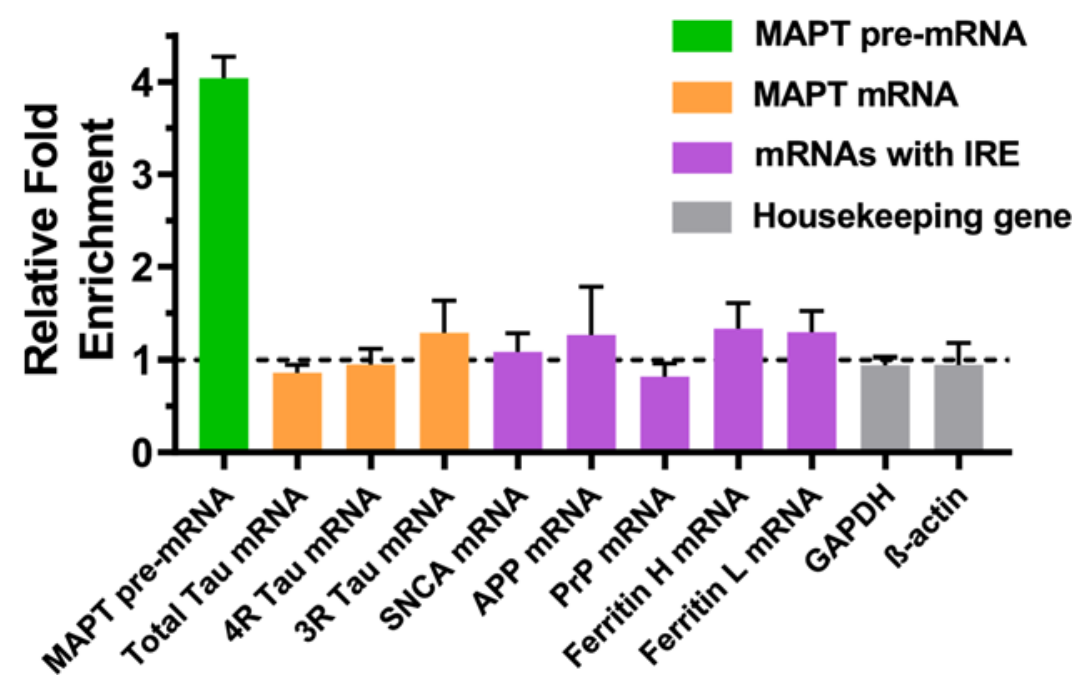

Figure S14: The relative fold enrichment of MAPT pre-mRNAs, MAPT mRNAs, other mRNAs contain IRE and two housekeeping mRNAs pulled down by 11 in Chem-CLIP experiments. Error bars indicate SD. 


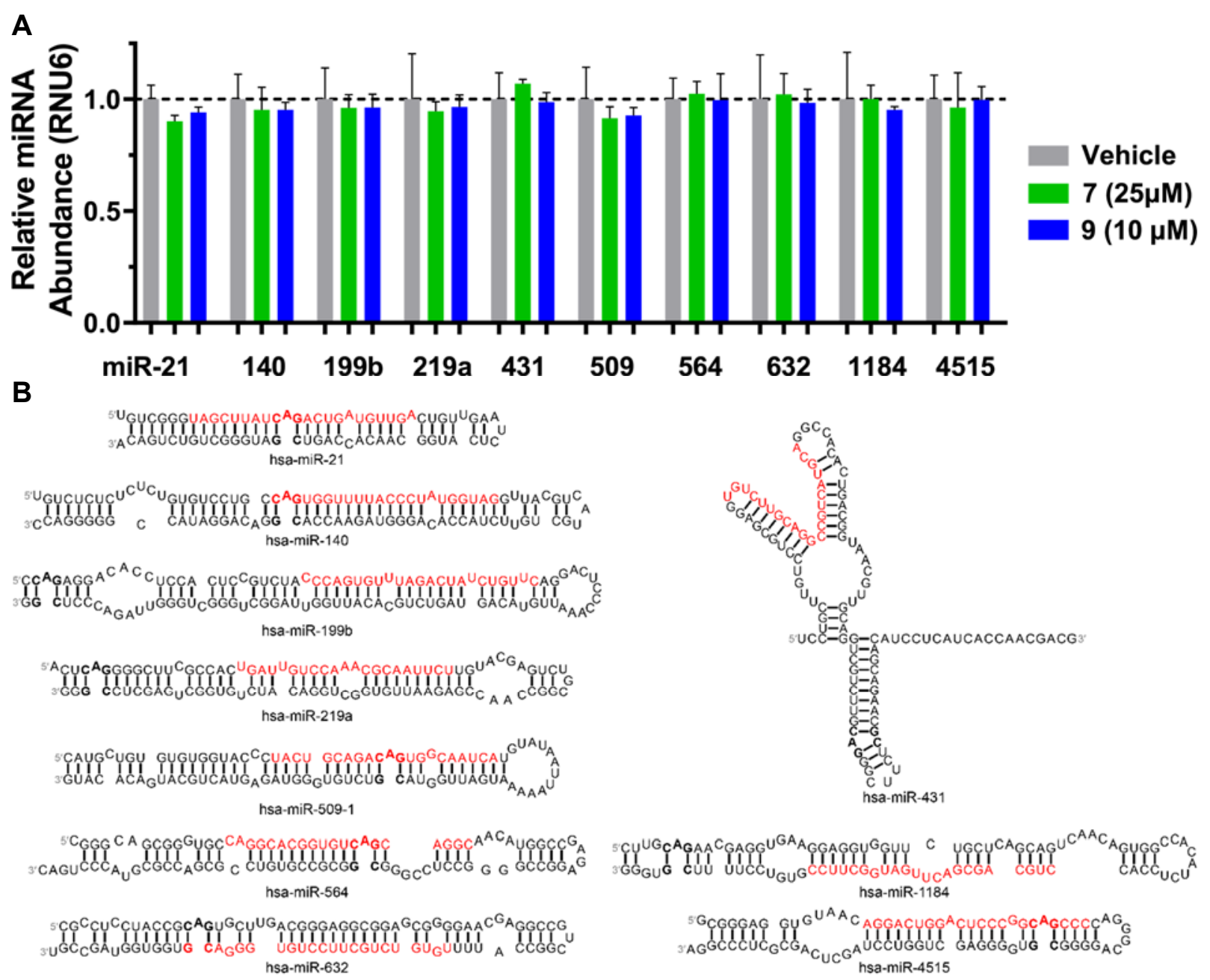

Figure S15: The effects of compounds 7 and 9 on microRNA expression. (A) Expression profiles of miRNAs containing the A-bulge motif found in the tau exon 10 hairpin. (B) Secondary structures of miRNA precursors used in this study. Red letters correspond to mature miRNAs. Bold letters correspond to $5^{\prime} \mathrm{C} A \mathrm{G} / 3^{\prime} \mathrm{GC}$ motifs. Note: the structure shown for hsa-miR-431 is the lowest free energy structure predicted by RNAstructure and differs from that shown in miRBase. ${ }^{11}$ Error bars indicate SD. 


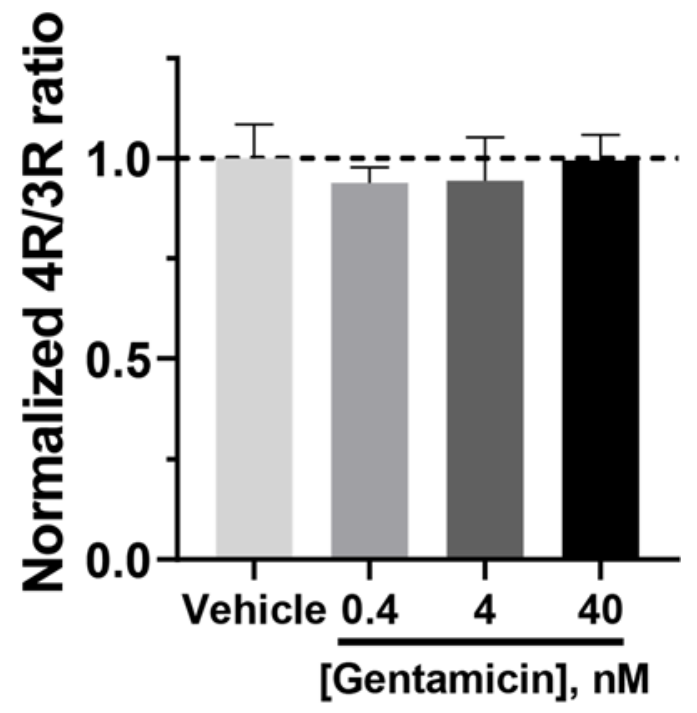

Figure S16: The effect of gentamicin on relative amounts of 4R and 3R Tau mRNA in LAN5 cells assessed by RT-qPCR. Gentamicin did not reduce the 4R/3R tau ratio in LAN5 cells at $0.4,4$, and $40 \mathrm{nM}$ concentrations. Error bars indicate SD. 


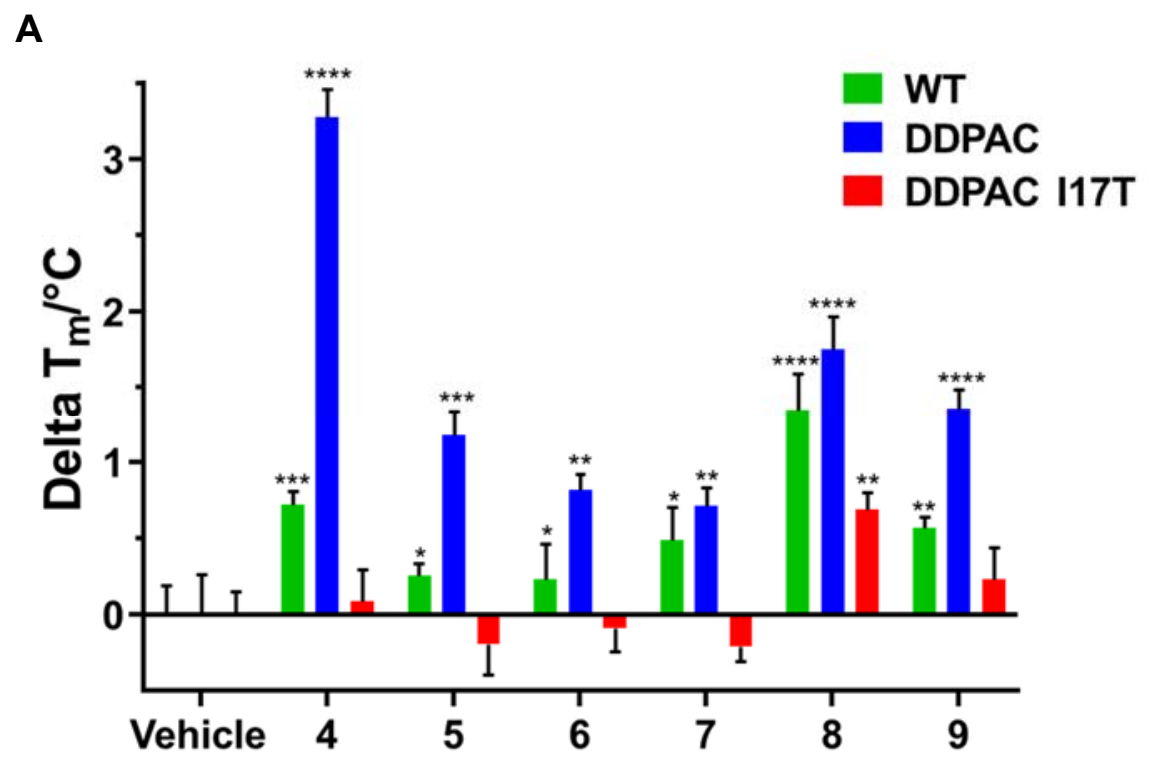

B

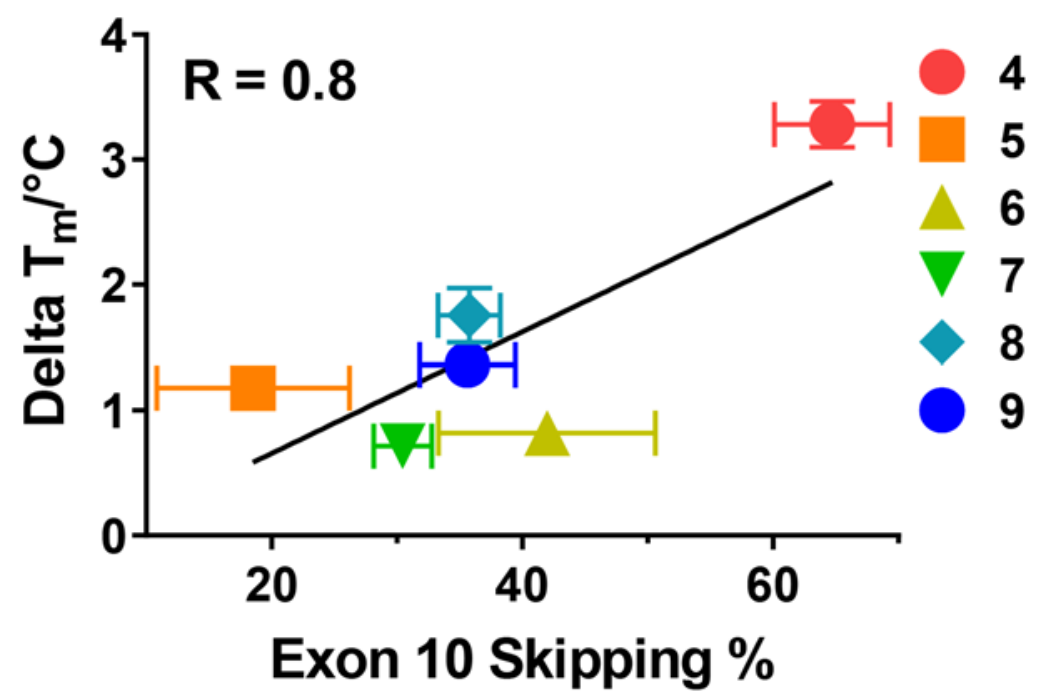

Figure S17: The effect of compounds 4 to 9 on the thermodynamic stability of Tau RNA constructs. (A) Change in melting temperature of WT, DDPAC, and DDPAC+117T constructs upon addition of compounds 4 to 9 . (B) Correlation between thermal melting experiments and exon 10 skipping determined at $10 \mu \mathrm{M}$ for all compounds except 6 and 7 , which were determined at $12.5 \mu \mathrm{M}$. Error bars indicate SD. ${ }^{*} \mathrm{P}<0.05$, ${ }^{* *} \mathrm{P}<0.01$, ${ }^{* * *} \mathrm{P}<0.001$, and ${ }^{* * * *} \mathrm{P}<0.0001$ as determined by a two-tailed Student t-test. 
A. $1 D^{1} \mathrm{H}$ NMR of 4

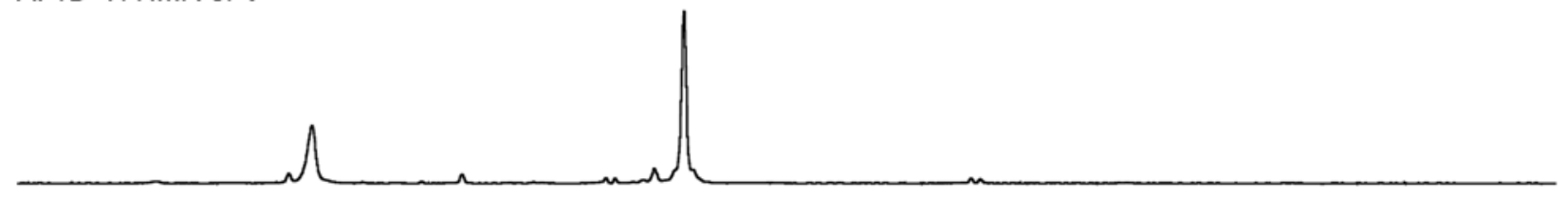

B. WaterLOGSY NMR spectra of 4

buffer

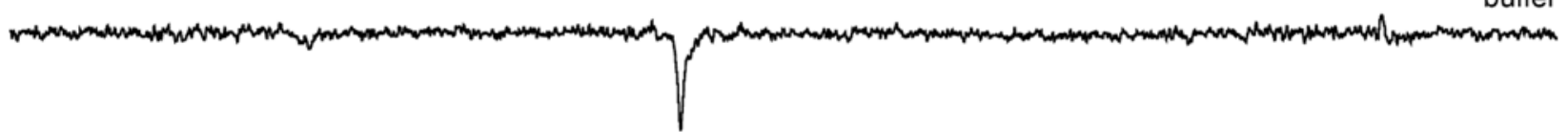

+ WT Tau duplex

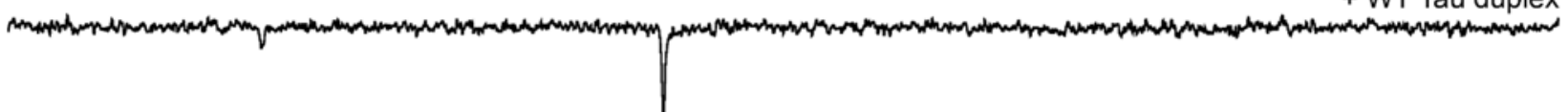

+ DDPAC Tau duplex

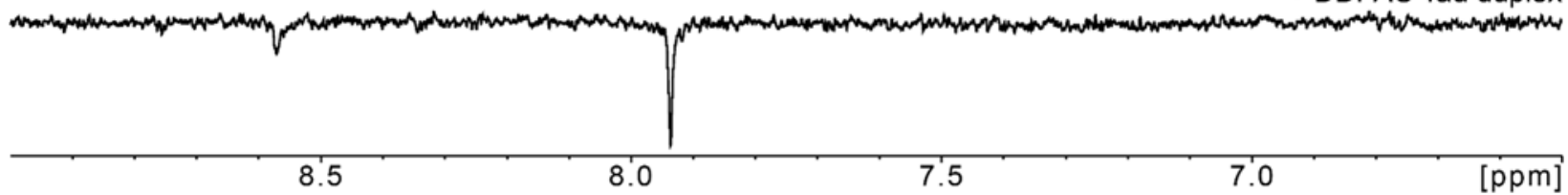

Figure S18: 1D ${ }^{1} \mathrm{H}$ and WaterLOGSY NMR spectra of 4. (A) $1 \mathrm{D}{ }^{1} \mathrm{H}$ spectrum of $300 \mu \mathrm{M}$ of 4 in buffer. (B) WaterLOGSY spectra of $300 \mu \mathrm{M}$ of 4 in buffer with or without $15 \mu \mathrm{M}$ of tau RNA constructs. Spectra were acquired at $25^{\circ} \mathrm{C}$. 
A

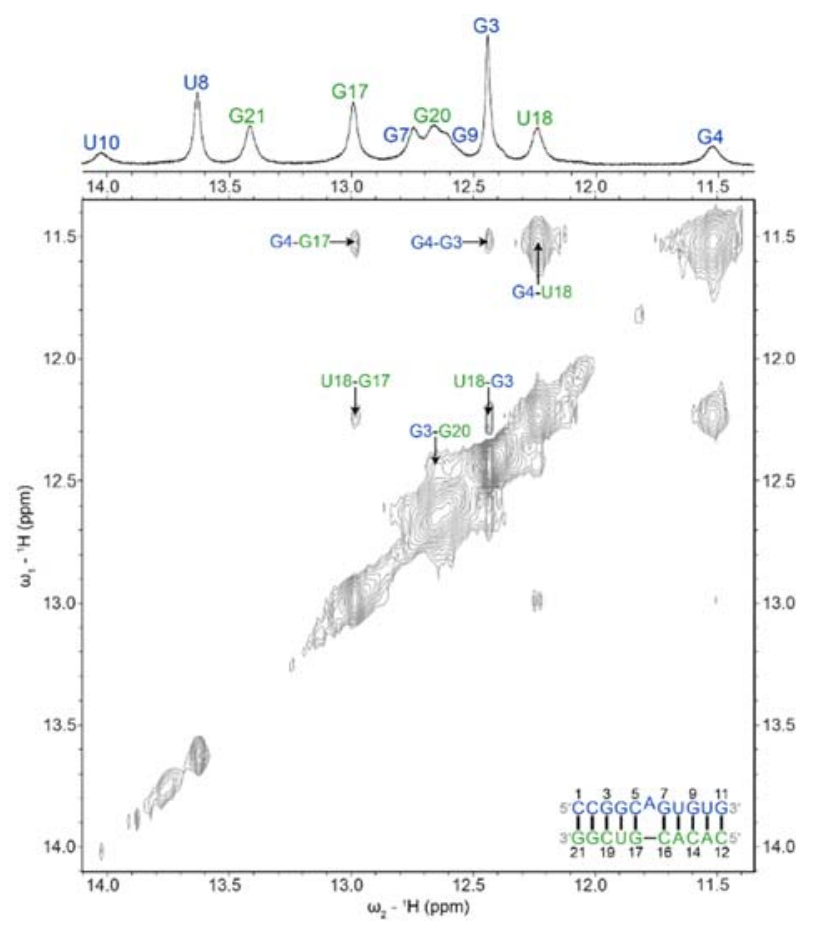

B

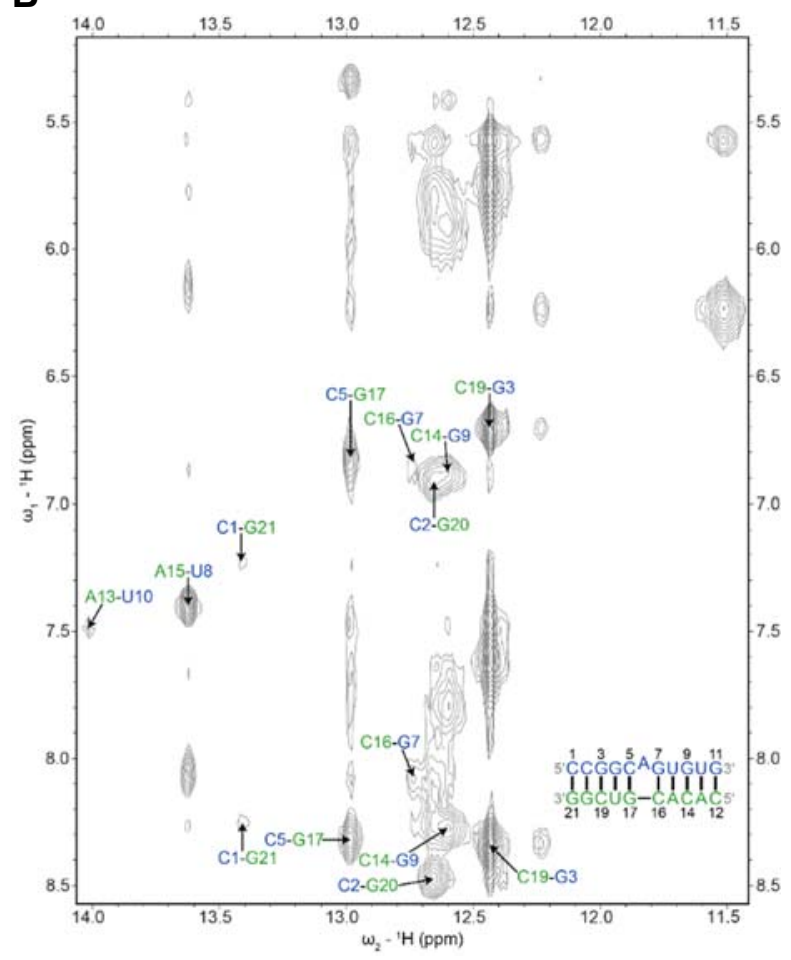

Figure S19: Imino proton regions of 1D and 2D ${ }^{1} \mathrm{H}$ NOESY NMR spectra of the unbound WT Tau RNA duplex. (A) Imino proton region of a 1D and a 2D proton NOESY spectrum. (B) Imino to amino/non-exchangeable proton region. Labels correspond to $\mathrm{AH} 2$ to $\mathrm{UH} 3$ and $\mathrm{GH} 1$ to $\mathrm{C}$ amino NOEs within base pairs. In each label, the first residue corresponds to $\mathrm{AH} 2$ or a $\mathrm{C}$ amino proton and the second residue corresponds to $\mathrm{UH} 3$ or $\mathrm{GH} 1$. In each spectrum, blue correspond to residues 1 to 11 and green correspond to residues 12 to 21 . 
A

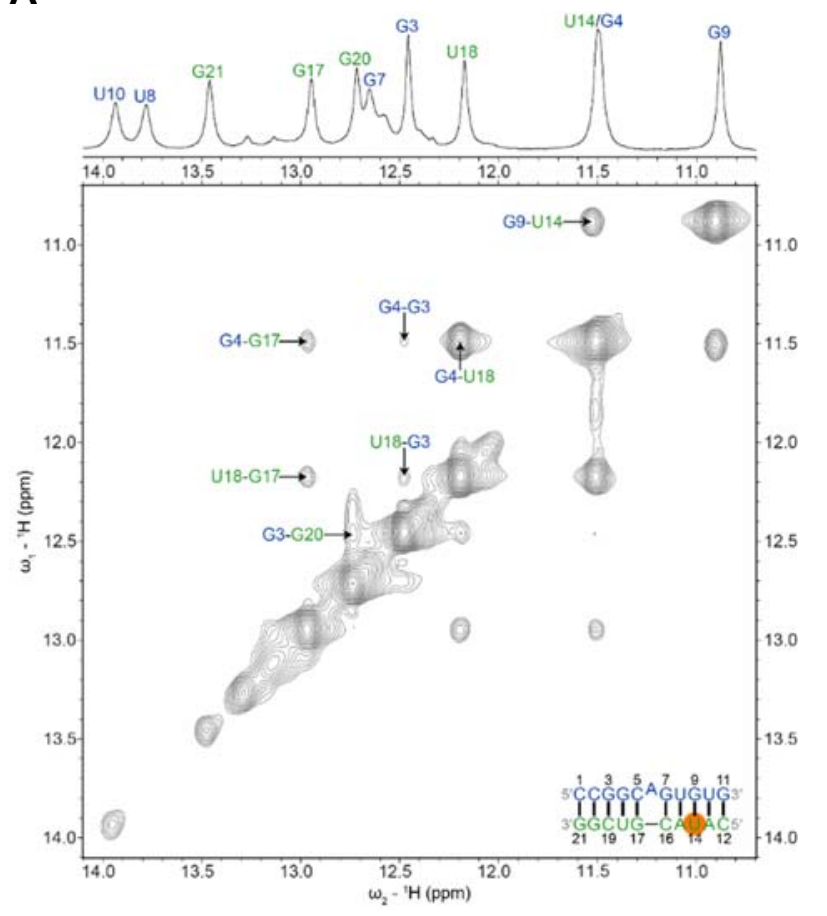

B

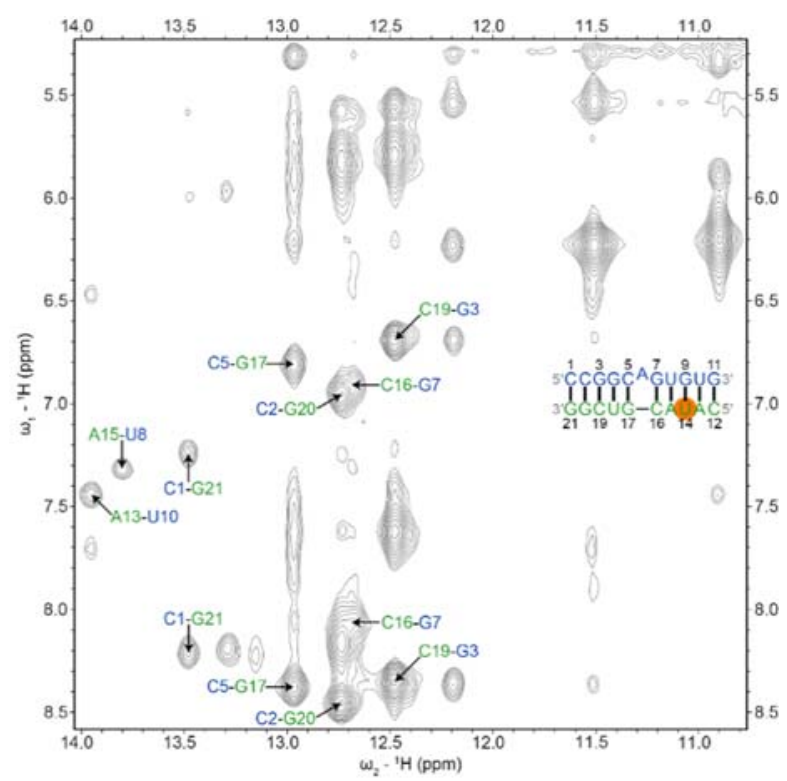

Figure S20: Imino proton regions of 1D and 2D ${ }^{1} \mathrm{H}$ NOESY NMR spectra of the unbound DDPAC Tau RNA duplex. (A) Imino proton region of a 1D and a 2D proton NOESY spectrum. (B) Imino to amino/non-exchangeable proton region. Labels correspond to $\mathrm{AH} 2$ to $\mathrm{UH} 3$ and $\mathrm{GH} 1$ to $\mathrm{C}$ amino NOEs within base pairs. In each label, the first residue corresponds to $\mathrm{AH} 2$ or a $\mathrm{C}$ amino proton and the second residue corresponds to $\mathrm{UH} 3$ or $\mathrm{GH} 1$. In each spectrum, blue correspond to residues 1 to 11 and green correspond to residues 12 to 21 . The $\mathrm{C}$-to-U mutation in the secondary structure of the construct is highlighted orange. 
A

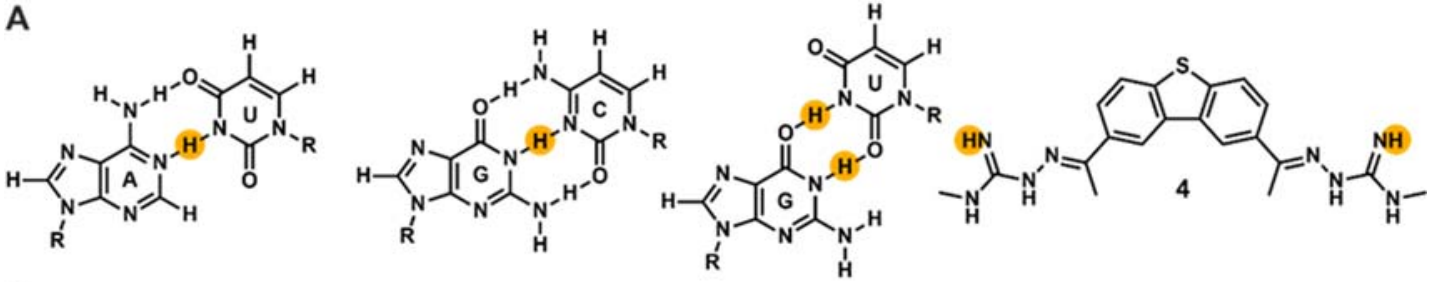

B
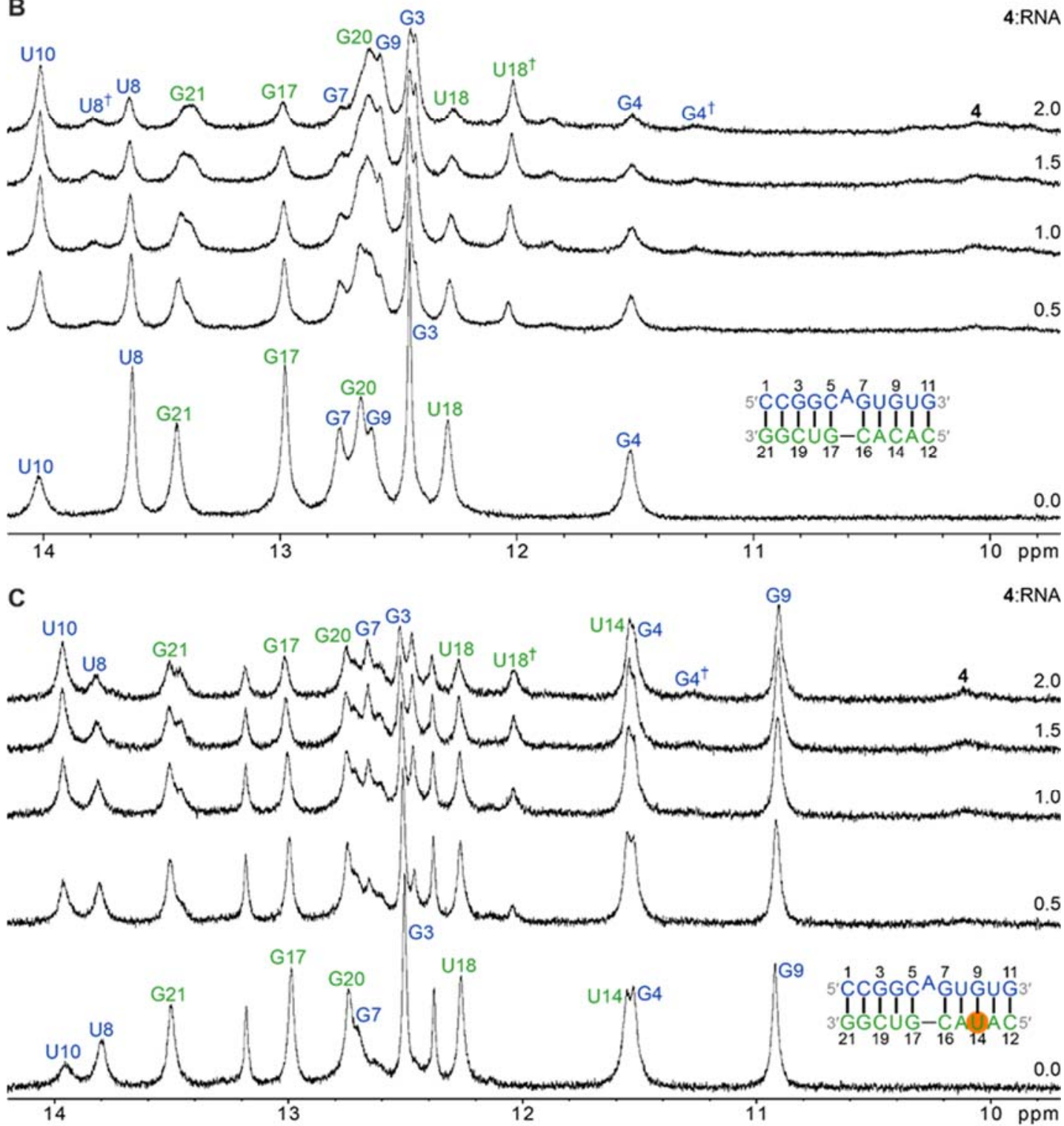

Figure S21: NMR titrations of WT and DDPAC stem mimic duplexes with 4. (A) The chemical structures of 4 and $A U, G C$, and GU base pairs. Imino protons are highlighted yellow. (B) The 1D ${ }^{1} \mathrm{H}$ NMR titration spectra of the WT stem mimic duplex with 4. (C) The $1 \mathrm{D}{ }^{1} \mathrm{H}$ NMR titration spectra of the DDPAC stem mimic duplex with 4. The C-to-U mutation in the DDPAC construct is highlighted orange. Blue labels correspond to imino proton resonances of the top strand of the duplex and green labels correspond to the bottom strand. The molar ratio of 4 to RNA for each set of spectra is indicated on the right side. Spectra were collected at $9{ }^{\circ} \mathrm{C}$ with $250 \mu \mathrm{M}$ of RNA and 0 to $500 \mu \mathrm{M}$ of 4 at $125 \mu \mathrm{M}$ increments. 
A

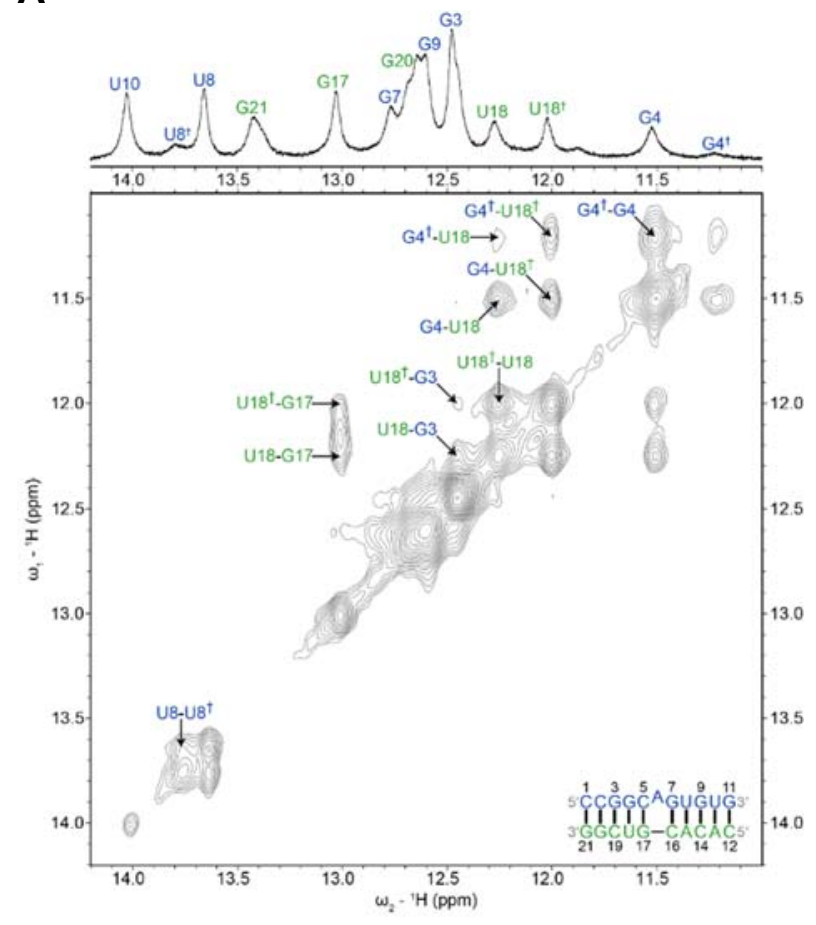

B

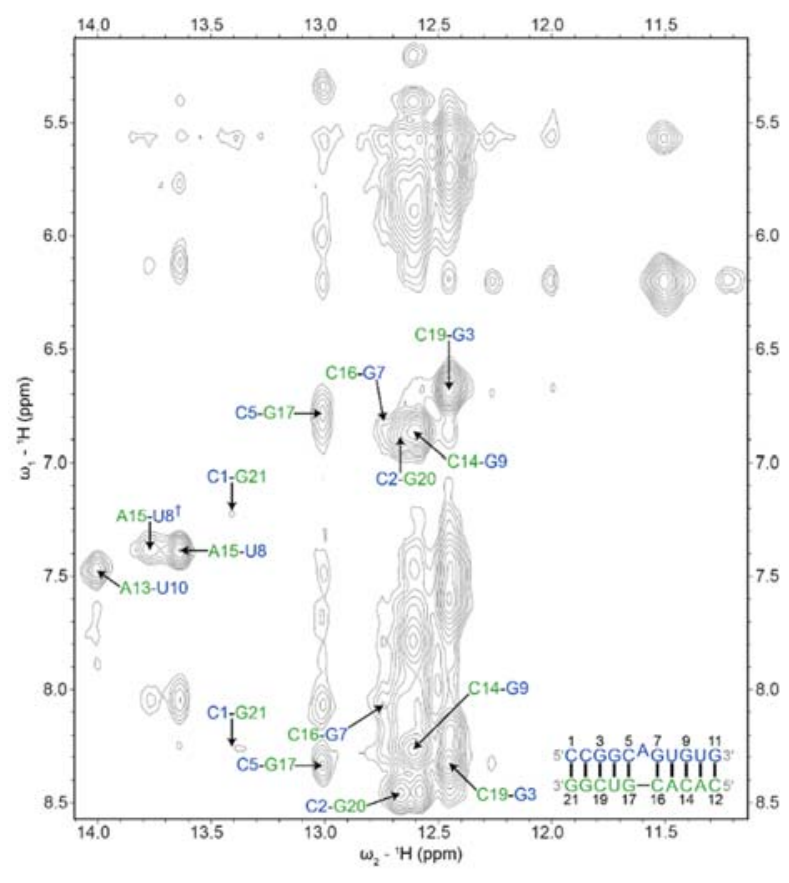

Figure S22: 1D and 2D ${ }^{1} \mathrm{H}$ NOESY NMR spectra of the WT Tau RNA duplex bound to 4 showing imino proton regions. (A) Imino proton region of a $1 \mathrm{D}$ and a $2 \mathrm{D}$ proton NOESY spectrum. Labels with daggers correspond to the bound conformation of the RNA construct. (B) Imino to amino/non-exchangeable proton region. Labels correspond to $\mathrm{AH} 2$ to $\mathrm{UH} 3$ and $\mathrm{GH} 1$ to $\mathrm{C}$ amino NOEs within base pairs. In each label, the first residue corresponds to $\mathrm{AH} 2$ or a $\mathrm{C}$ amino proton and the second residue corresponds to $\mathrm{UH} 3$ or $\mathrm{GH} 1$. In each spectrum, blue correspond to residues 1 to 11 and green correspond to residues 12 to 21 . 
A
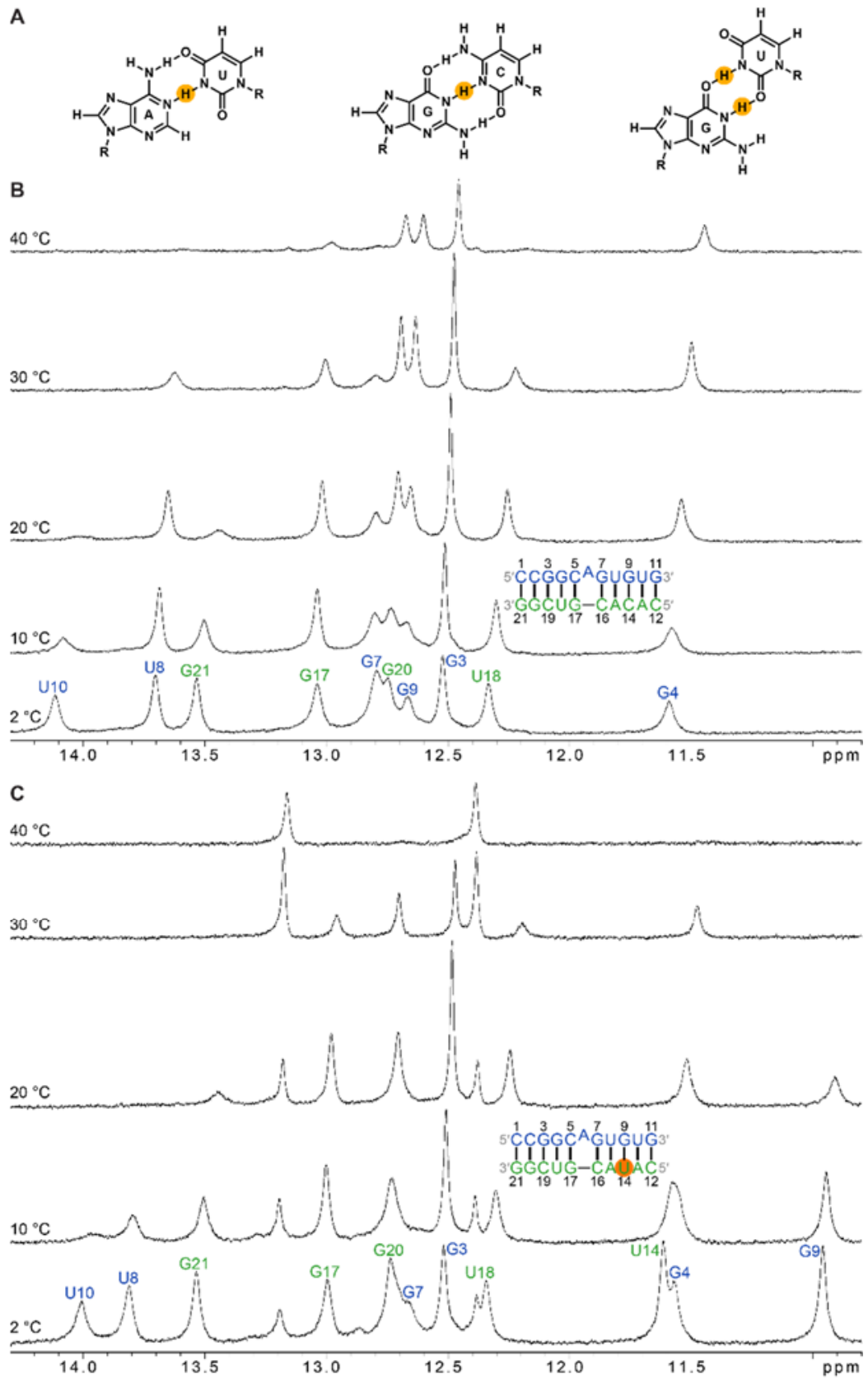

Figure S23: Imino proton region of $1 \mathrm{D}^{1} \mathrm{H}$ NMR spectra of unbound WT and DDPAC Tau RNA duplexes from 2 to $40{ }^{\circ} \mathrm{C}$. (A) The chemical structures of AU, GC, and GU base pairs. Imino protons are highlighted yellow. (B) The $1 \mathrm{D}{ }^{1} \mathrm{H}$ NMR spectra of the unbound WT stem mimic duplex. (C) The 1D ${ }^{1} \mathrm{H}$ NMR titration spectra of the unbound DDPAC stem mimic duplex. The Cto-U mutation in the DDPAC construct is highlighted orange. Blue labels correspond to imino proton resonances of the top strand of the duplex and green labels correspond to the bottom strand. The temperature for each spectrum is indicated on the left side. Spectra were collected with $150 \mu \mathrm{M}$ of RNA. 

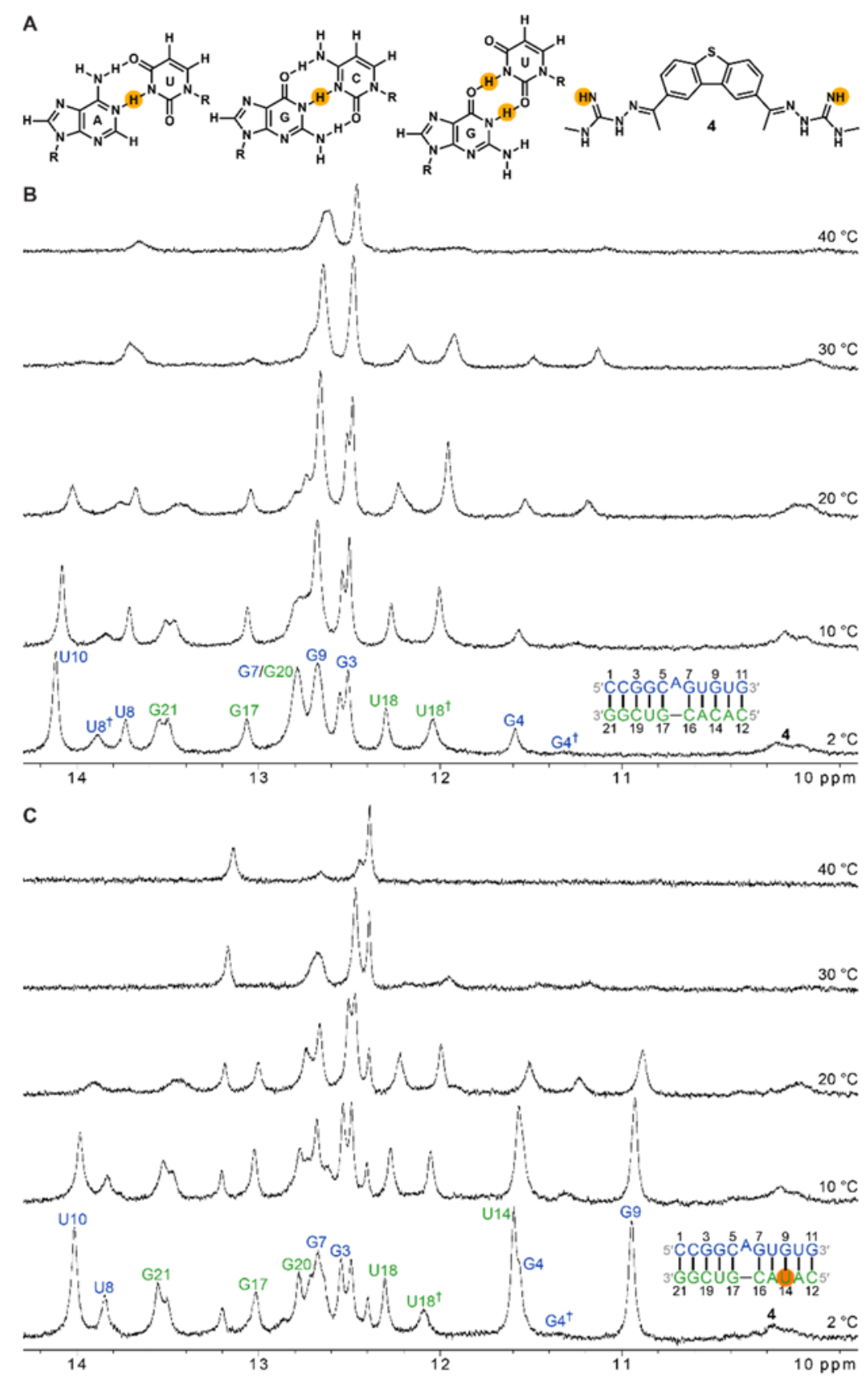

Figure S24: Imino proton region of $1 \mathrm{D}^{1} \mathrm{H}$ NMR spectra of 4-bound WT and DDPAC Tau RNA duplexes from 2 to $40{ }^{\circ} \mathrm{C}$. (A) The chemical structures of 4 and AU, GC, and GU base pairs. Imino protons are highlighted yellow. (B) The $1 \mathrm{D}{ }^{1} \mathrm{H}$ NMR spectra of the 4-bound WT stem mimic duplex. (C) The $1 \mathrm{D}{ }^{1} \mathrm{H}$ NMR titration spectra of the 4-bound DDPAC stem mimic duplex. The Cto-U mutation in the DDPAC construct is highlighted orange. Blue labels correspond to imino proton resonances of the top strand of the duplex and green labels correspond to the bottom strand. The temperature for each spectrum is indicated on the right side. Spectra were collected with $150 \mu \mathrm{M}$ of RNA and 4. 


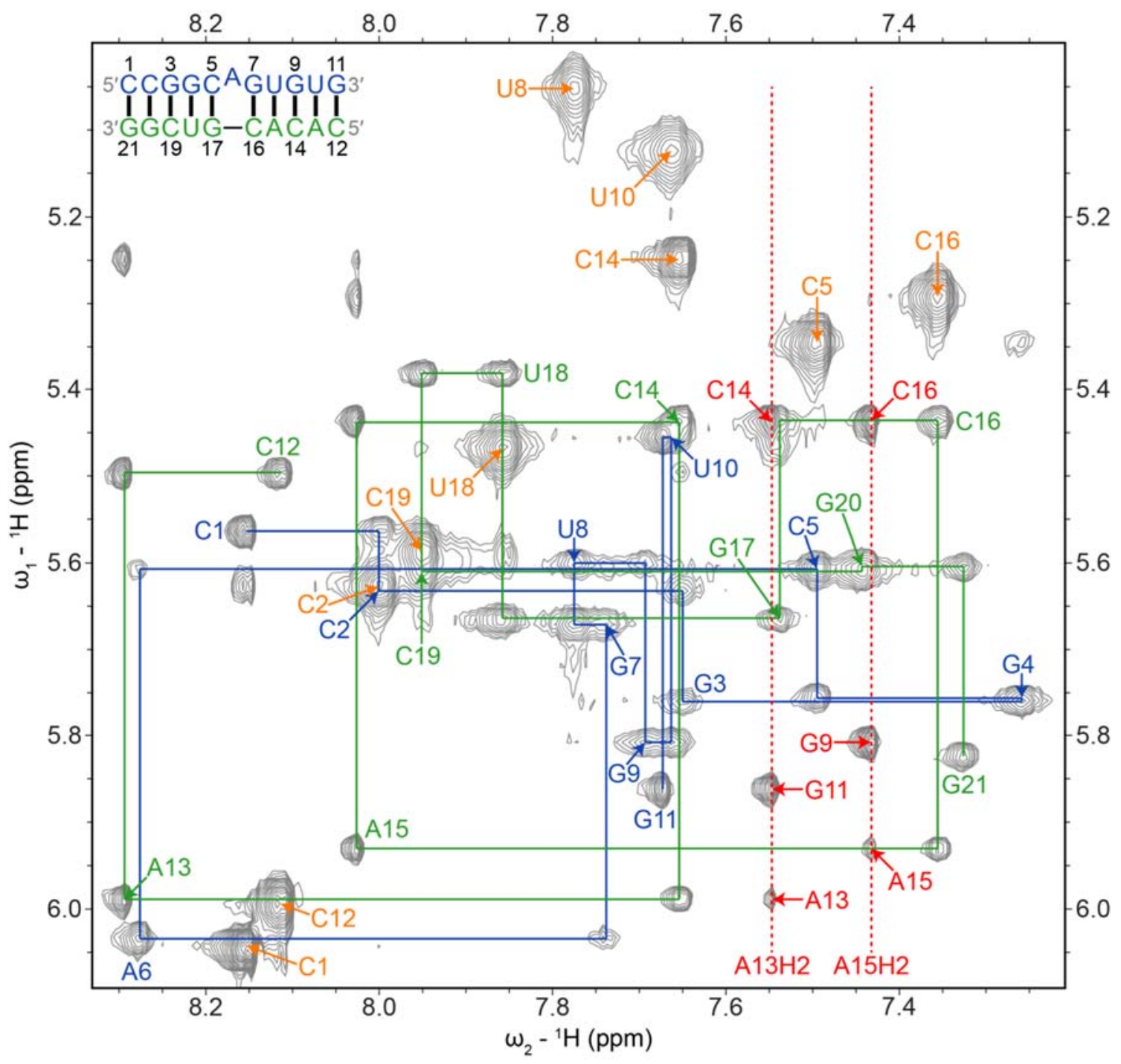

Figure S25: H1'-H6/H8 region of a 2D ${ }^{1} \mathrm{H}$ NOESY NMR spectrum of the unbound WT Tau RNA duplex. Sequential $\mathrm{H} 1$ ' to $\mathrm{H} 6 / \mathrm{H} 8$ walks for residues 1 to 11 and 12 to 21 are depicted with blue and green lines, respectively. Blue labels correspond to $\mathrm{H} 1^{\prime}$ to $\mathrm{H} 6 / \mathrm{H} 8$ NOEs of residues 1 to 11. Green labels correspond to $\mathrm{H}^{\prime}$ ' to $\mathrm{H} 6 / \mathrm{H} 8$ NOEs of residues 12 to 21 . Orange labels correspond to $\mathrm{H} 5$ to $\mathrm{H} 6$ NOEs. Adenine $\mathrm{H} 2$ resonances are labeled red with dashed lines. The spectrum was acquired at $25^{\circ} \mathrm{C}$ with $400 \mathrm{~ms}$ mixing time and $700 \mu \mathrm{M}$ of RNA. 


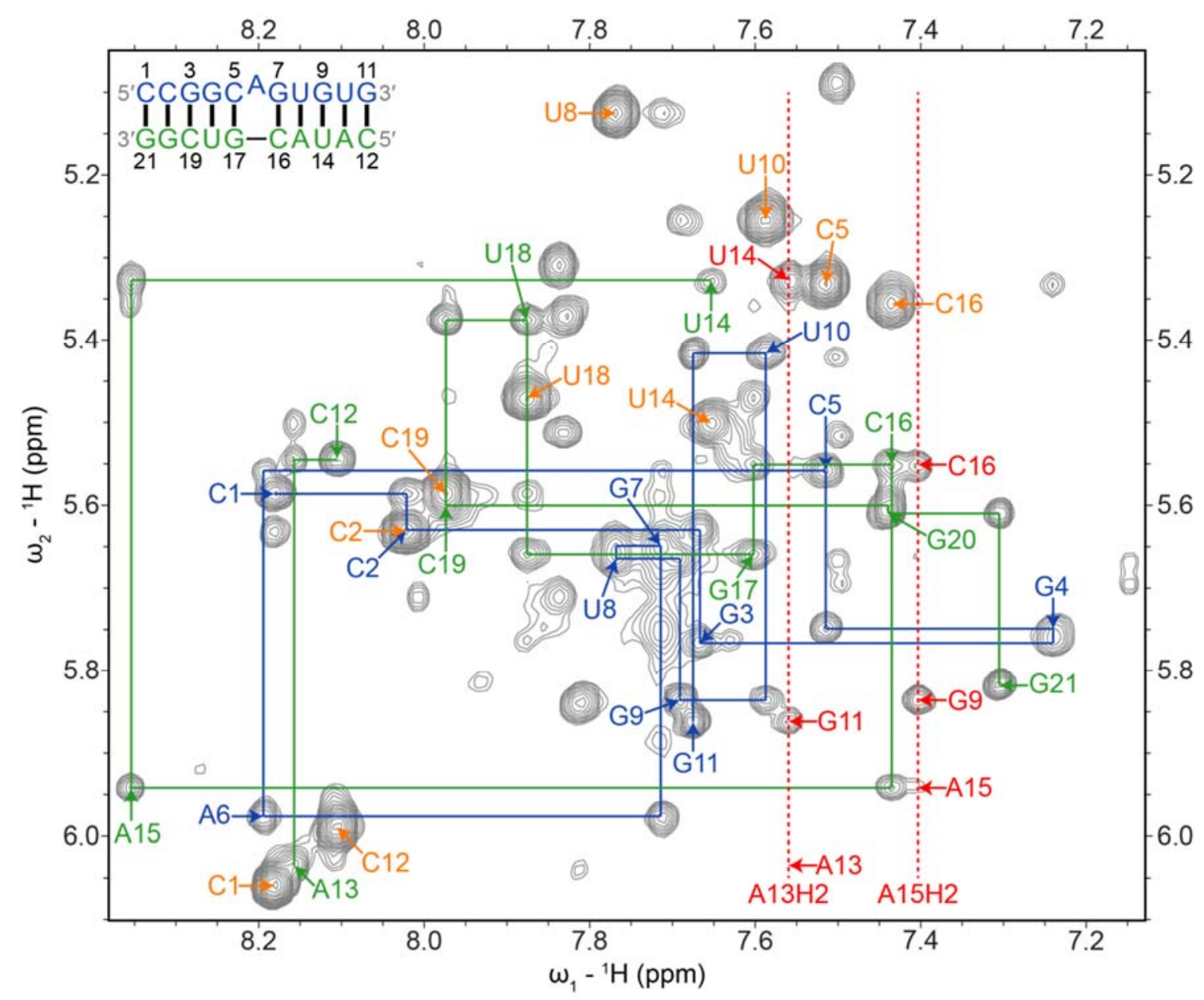

Figure S26: H1'-H6/H8 region of a 2D ${ }^{1} \mathrm{H}$ NOESY NMR spectrum of the unbound DDPAC Tau RNA duplex. Sequential $\mathrm{H}^{\prime}$ ' to $\mathrm{H} 6 / \mathrm{H} 8$ walks for residues 1 to 11 and 12 to 21 are depicted with blue and green lines, respectively. Blue labels correspond to $\mathrm{H} 1$ ' to $\mathrm{H} 6 / \mathrm{H} 8 \mathrm{NOEs}$ of residues 1 to 11. Green labels correspond to $\mathrm{H}^{\prime}{ }^{\prime}$ to $\mathrm{H} 6 / \mathrm{H} 8$ NOEs of residues 12 to 21 . Orange labels correspond to $\mathrm{H} 5$ to $\mathrm{H} 6$ NOEs. Adenine $\mathrm{H} 2$ resonances are labeled red with dashed lines. The spectrum was acquired at $25^{\circ} \mathrm{C}$ with $400 \mathrm{~ms}$ mixing time and $400 \mu \mathrm{M}$ of RNA. 


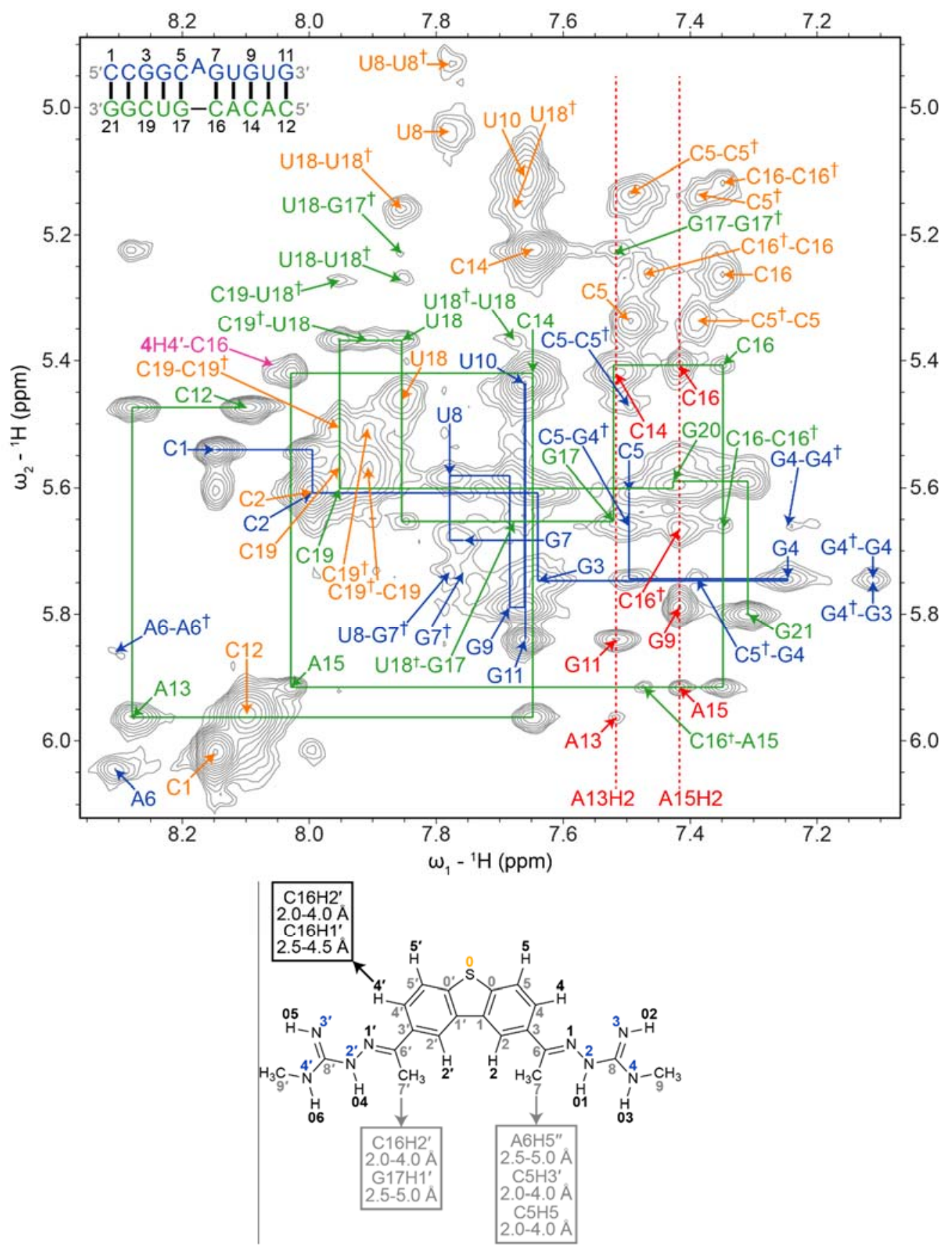

Figure S27: H1'-H6/H8 region of a 2D ${ }^{1} \mathrm{H}$ NOESY NMR spectrum of the 4-WT Tau RNA. Sequential $\mathrm{H} 1$ ' to $\mathrm{H} 6 / \mathrm{H} 8$ walks for residues 1 to 11 and 12 to 21 are depicted with blue and green lines, respectively. Blue labels correspond to $\mathrm{H} 1$ ' to $\mathrm{H} 6 / \mathrm{H} 8$ NOEs of residues 1 to 11 . Green labels correspond to $\mathrm{H}^{1}$ ' to $\mathrm{H} 6 / \mathrm{H} 8$ NOEs of residues 12 to 21 . The NOE between $\mathrm{H} 4$ ' of 4 and $\mathrm{C} 16 \mathrm{H} 1$ ' is labeled pink. Orange labels correspond to $\mathrm{H} 5$ to $\mathrm{H} 6 \mathrm{NOEs}$. Adenine $\mathrm{H} 2$ resonances are labeled red with dashed lines. ${ }^{\dagger}$ Bound conformation resonances. In the chemical structure of 4, the numbering scheme for NMR studies is shown. Black numbers correspond to hydrogens, gray correspond to carbons, blue correspond to nitrogens, and yellow corresponds to sulfur. Arrows indicate hydrogens to which $\mathbf{4}$ has intermolecular NOEs and are colored according to the atoms of $\mathbf{4}$ and labeled with distances used as restraints for modeling the complex. The spectrum was acquired at $25^{\circ} \mathrm{C}$ with 400 ms mixing time and $700 \mu \mathrm{M}$ of RNA and 4. 


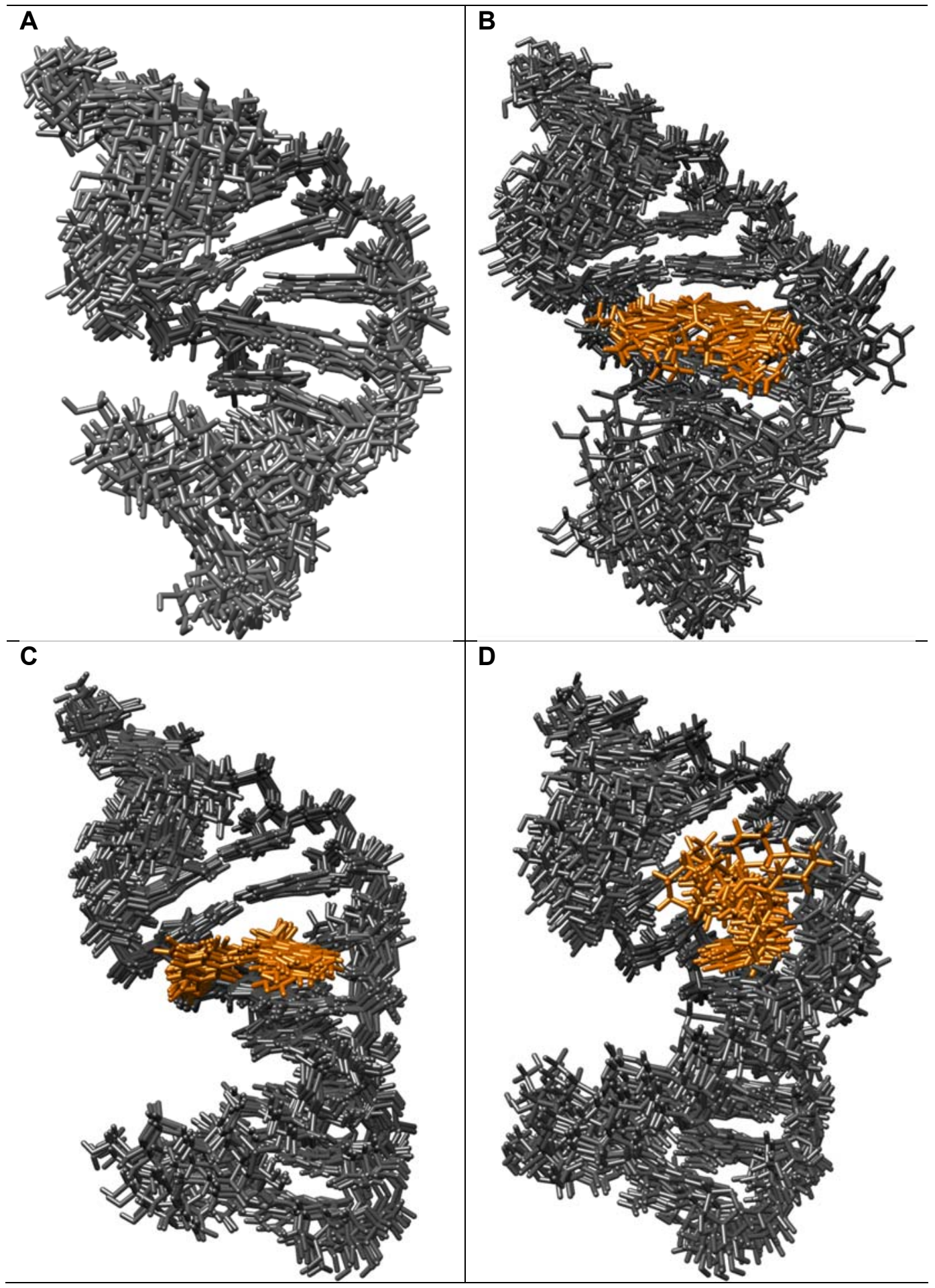

Figure S28: Overlay of the 10 lowest free energy structures of free- and bound-form Tau WT stem mimic RNA duplexes. Structures were generated by using interproton distances derived from NMR spectroscopy and restrained simulated annealing calculations. (A) Free form RNA. (B) 4-bound RNA. (C) 5-bound RNA. (D) 9-bound RNA. The RNA is colored gray in all structures and bound compounds are orange. 
A. $1 D^{1} \mathrm{H}$ NMR of 5

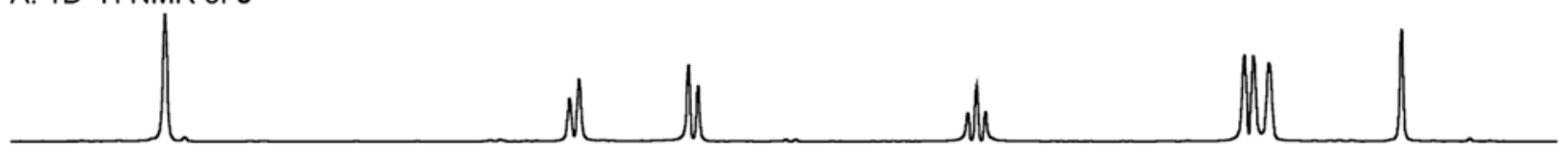

B. WaterLOGSY NMR spectra of 5

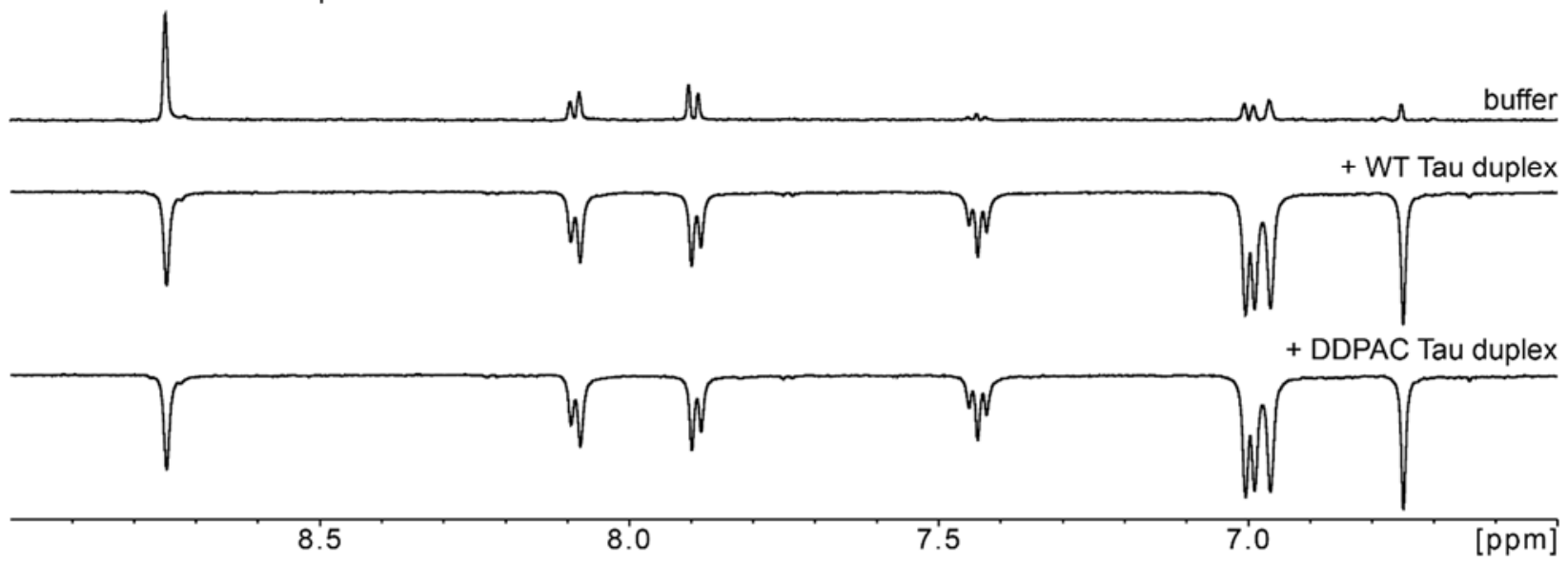

Figure S29: 1D ${ }^{1} \mathrm{H}$ and WaterLOGSY NMR spectra of 5. (A) $1 \mathrm{D}{ }^{1} \mathrm{H}$ spectrum of $300 \mu \mathrm{M}$ of 5 in buffer. (B) WaterLOGSY spectra of $300 \mu \mathrm{M}$ of 5 in buffer with or without $15 \mu \mathrm{M}$ of tau RNA constructs. Spectra were acquired at $25^{\circ} \mathrm{C}$. 
A. $1 D^{1} \mathrm{H}$ NMR of 9

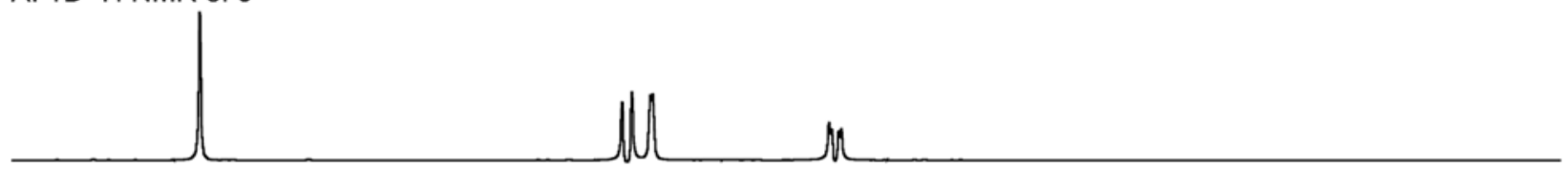

B. WaterLOGSY NMR spectra of 9
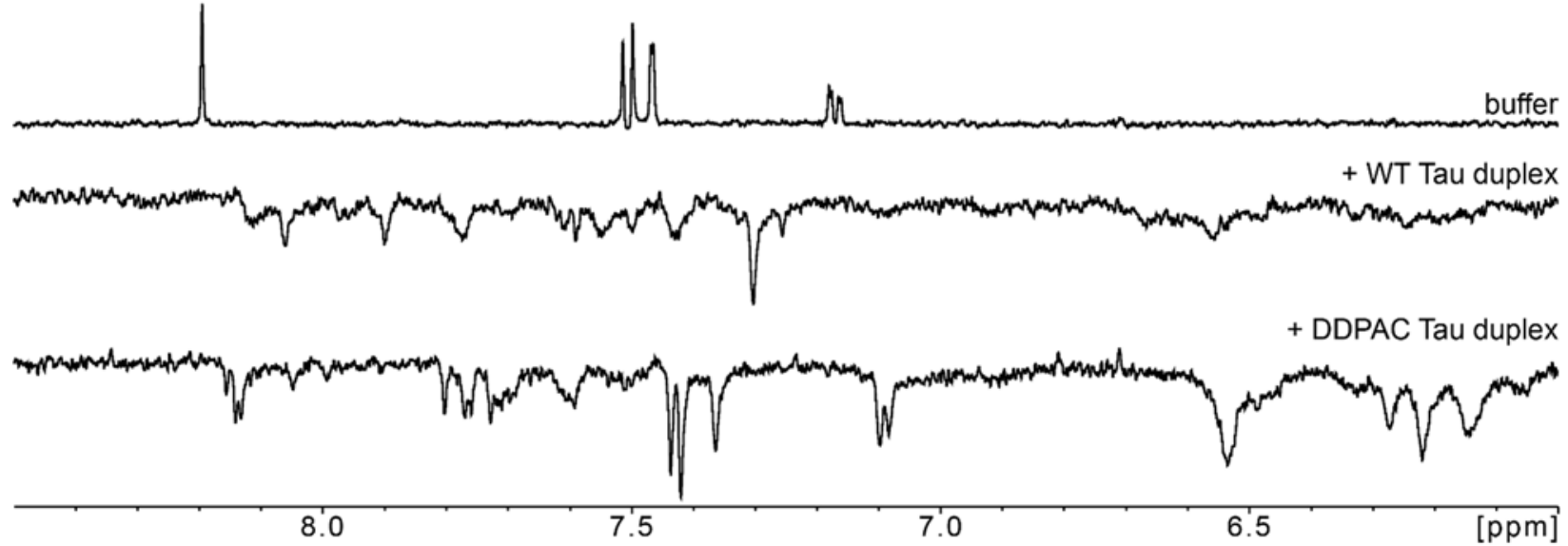

Figure S30: 1D ${ }^{1} \mathrm{H}$ and WaterLOGSY NMR spectra of 9. (A) $1 \mathrm{D}{ }^{1} \mathrm{H}$ spectrum of $300 \mu \mathrm{M}$ of 9 in buffer. (B) WaterLOGSY spectra of $300 \mu \mathrm{M}$ of 9 in buffer with or without $15 \mu \mathrm{M}$ of tau RNA constructs. Spectra were acquired at $25^{\circ} \mathrm{C}$. 
A. $1 D^{1}{ }^{1}$ NMR of 6

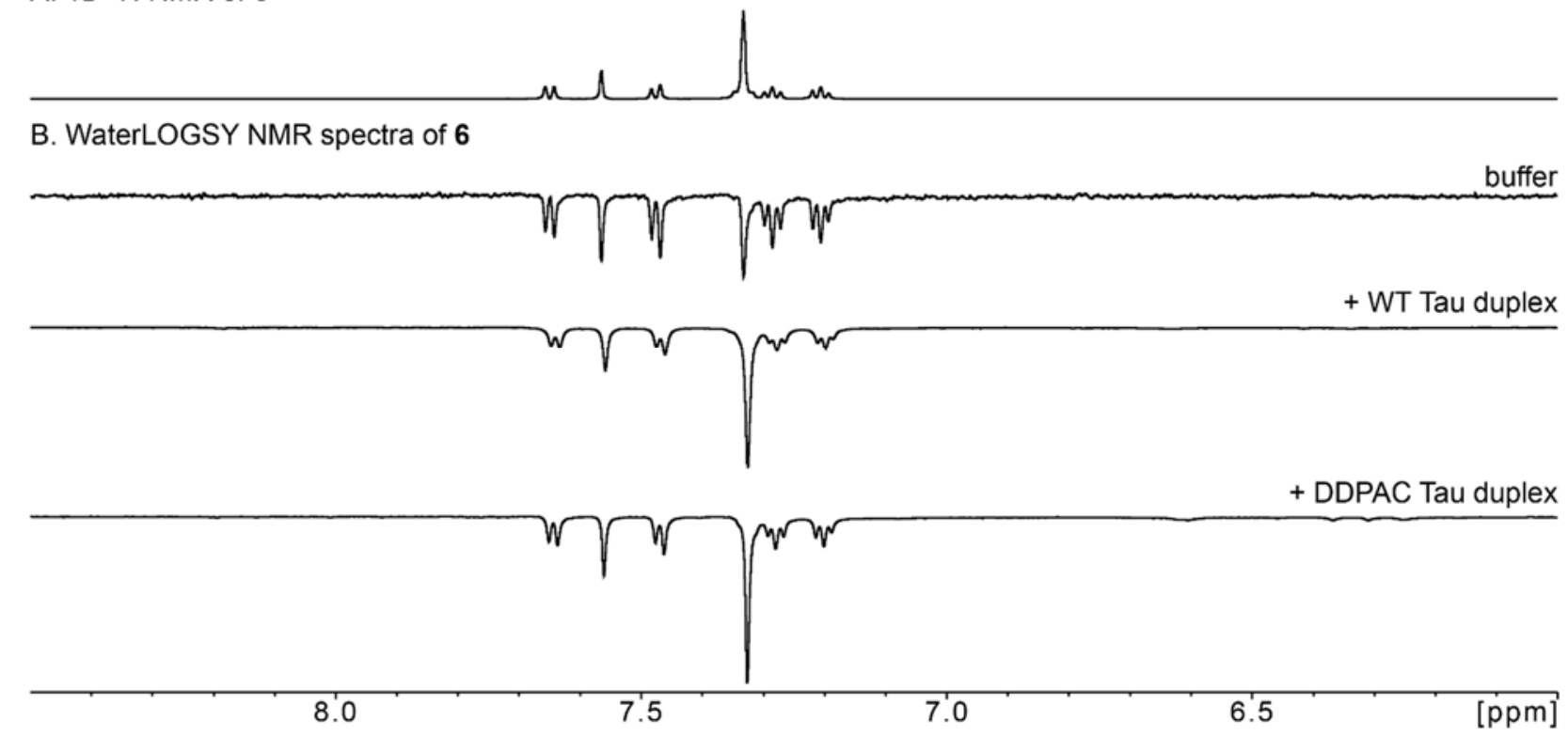

Figure S31: 1D ${ }^{1} \mathrm{H}$ and WaterLOGSY NMR spectra of 6. (A) $1 \mathrm{D}^{1} \mathrm{H}$ spectrum of $300 \mu \mathrm{M}$ of 6 in buffer. (B) WaterLOGSY spectra of $300 \mu \mathrm{M}$ of 6 in buffer with or without $15 \mu \mathrm{M}$ of tau RNA constructs. Spectra were acquired at $25^{\circ} \mathrm{C}$. 
A. $1 D^{1} \mathrm{H}$ NMR of 7

B.

B. WaterLOGSY NMR spectra of 7

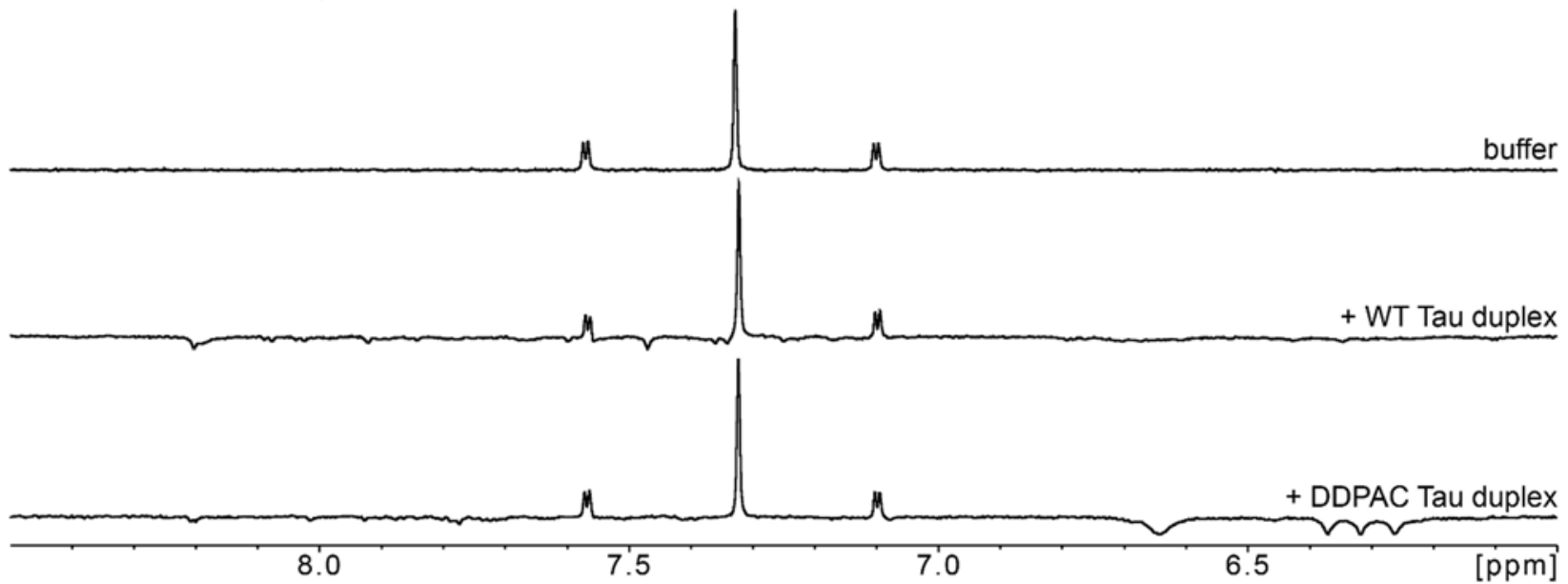

Figure S32: 1D ${ }^{1} \mathrm{H}$ and WaterLOGSY NMR spectra of 7. (A) $1 \mathrm{D}{ }^{1} \mathrm{H}$ spectrum of $300 \mu \mathrm{M}$ of 7 in buffer. (B) WaterLOGSY spectra of $300 \mu \mathrm{M}$ of 7 in buffer with or without $15 \mu \mathrm{M}$ of tau RNA constructs. Spectra were acquired at $25^{\circ} \mathrm{C}$. 
A. $1 D^{1}{ }^{1}$ NMR of 8

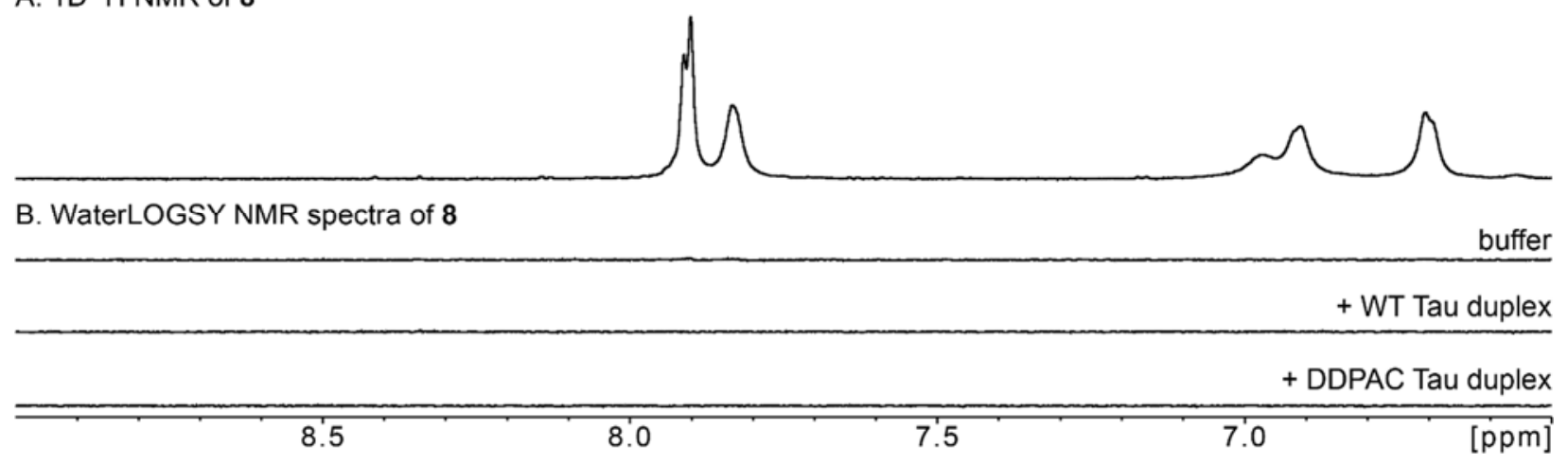

Figure S33: 1D ${ }^{1} \mathrm{H}$ and WaterLOGSY NMR spectra of 8. (A) $1 \mathrm{D}{ }^{1} \mathrm{H}$ spectrum of $300 \mu \mathrm{M}$ of 8 in buffer. (B) WaterLOGSY spectra of $300 \mu \mathrm{M}$ of 8 in buffer with or without $15 \mu \mathrm{M}$ of tau RNA constructs. Spectra were acquired at $25^{\circ} \mathrm{C}$. 
A
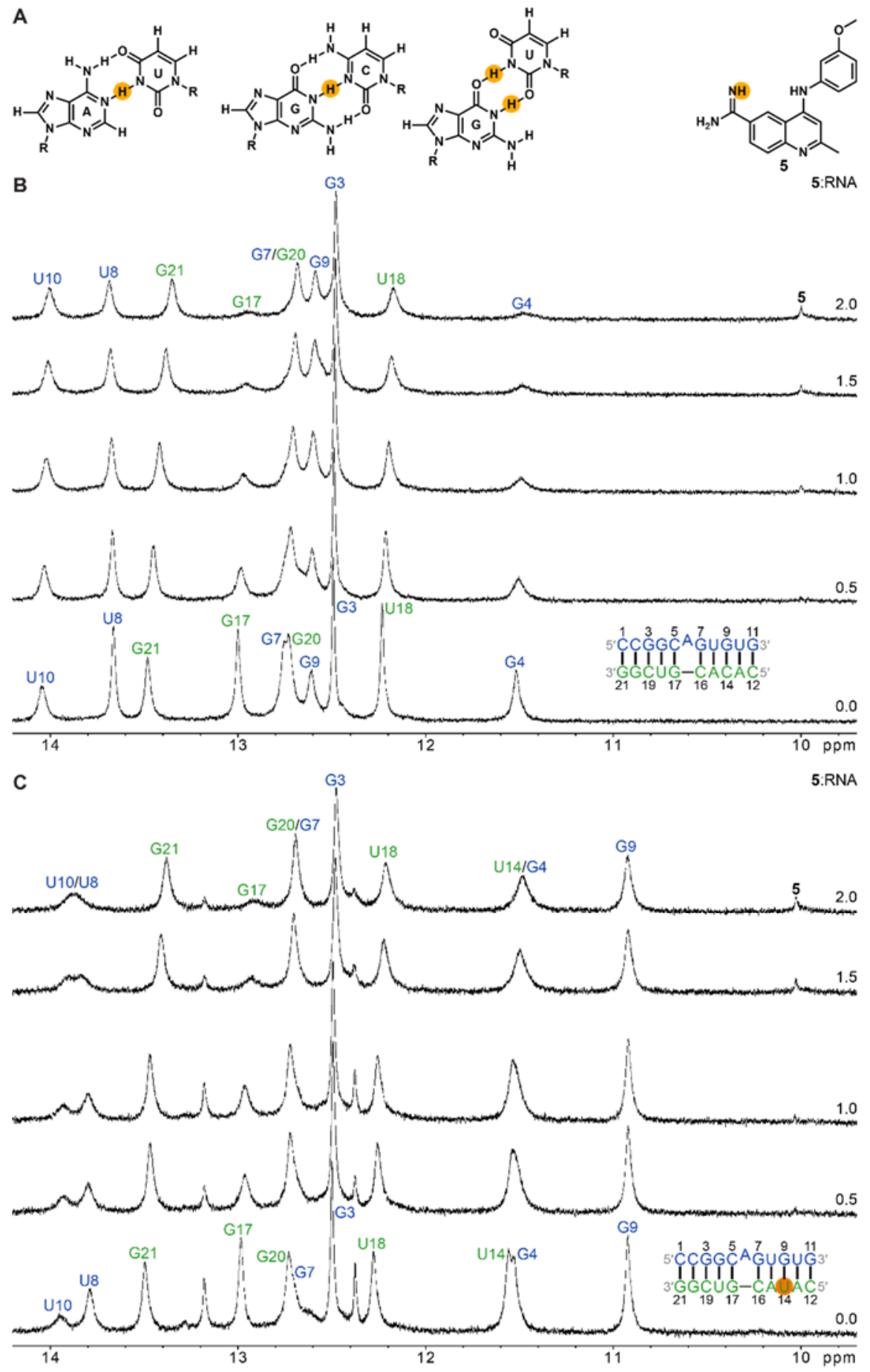

Figure S34: NMR titrations of WT and DDPAC stem mimic duplexes with 5. (A) The chemical structures of $\mathbf{5}$ and $A U, G C$, and GU base pairs. Imino protons are highlighted yellow. (B) The 1D ${ }^{1} \mathrm{H}$ NMR titration spectra of the WT stem mimic duplex with 5 . (C) The $1 \mathrm{D}{ }^{1} \mathrm{H}$ NMR titration spectra of the DDPAC stem mimic duplex with $\mathbf{5}$. The C-to-U mutation in the DDPAC construct is highlighted orange. Blue labels correspond to imino proton resonances of the top stem of the duplex and green labels correspond to the bottom stem. The molar ratio of 5 to RNA for each set of spectra is indicated on the right side. Spectra were collected at $9^{\circ} \mathrm{C}$ with $100 \mu \mathrm{M}$ of RNA and 0 to $200 \mu \mathrm{M}$ of 5 at $50 \mu \mathrm{M}$ increments. 
A

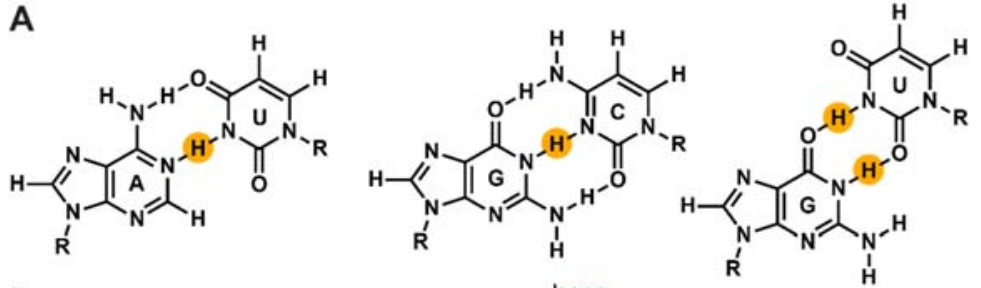<smiles>Cn1cc(C(=O)N2CCC(c3ccc(CN4CC(O)C4)cc3)CC2)c2ccccc21</smiles>

B

J18
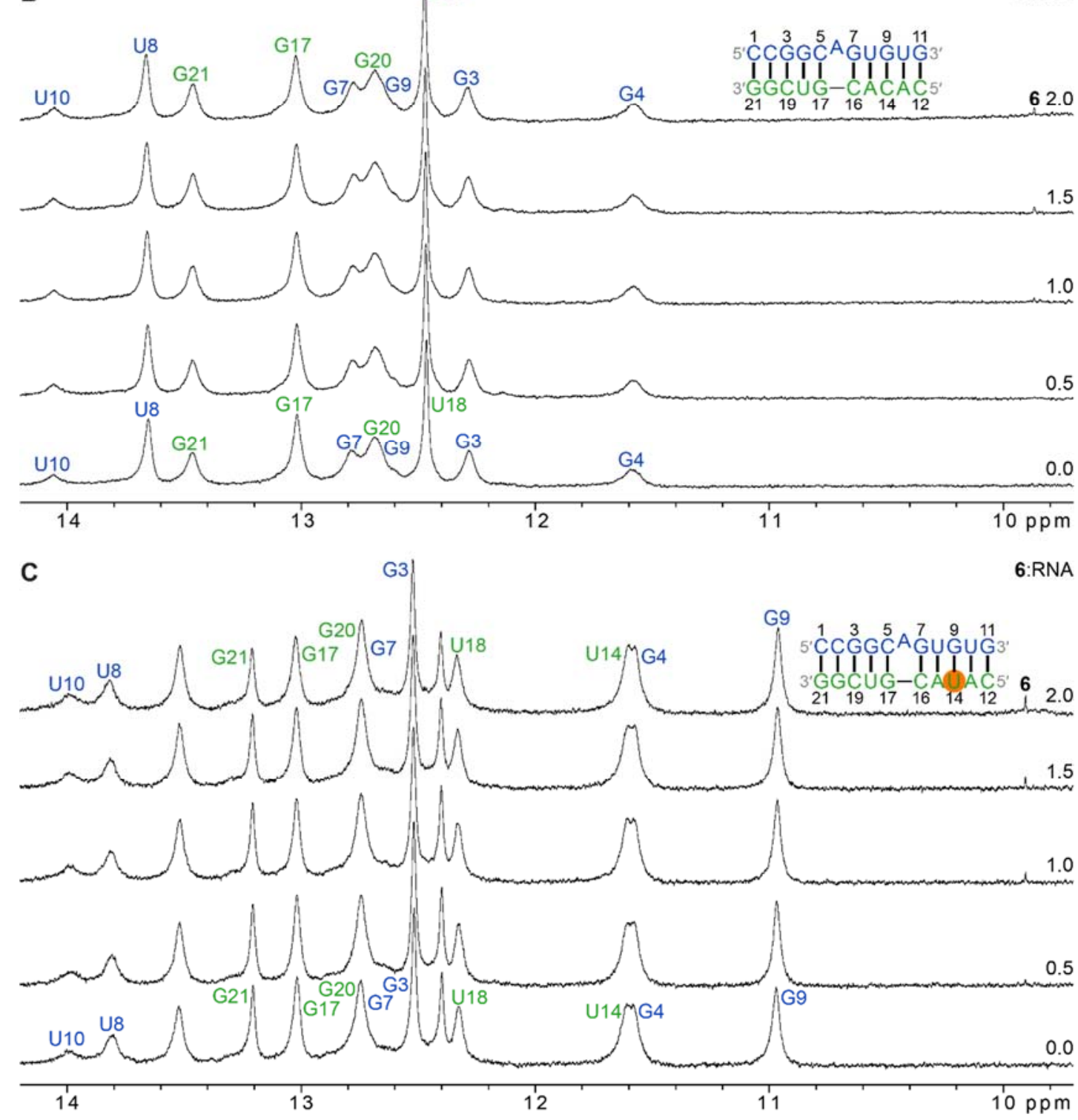

Figure S35: NMR titrations of WT and DDPAC stem mimic duplexes with 6. (A) The chemical structures of 6 and $A U, G C$, and GU base pairs. (B) The 1D ${ }^{1} \mathrm{H}$ NMR titration spectra of the WT stem mimic duplex with 6. (C) The 1D ${ }^{1} \mathrm{H}$ NMR titration spectra of the DDPAC stem mimic duplex with 6. The C-to- $U$ mutation in the DDPAC construct is highlighted orange. Blue labels correspond to imino proton resonances of the top stem of the duplex and green labels correspond to the bottom stem. The molar ratio of 6 to RNA for each set of spectra is indicated on the right side. Spectra were collected at $9{ }^{\circ} \mathrm{C}$ with $150 \mu \mathrm{M}$ of RNA and 0 to $300 \mu \mathrm{M}$ of 6 at $75 \mu \mathrm{M}$ increments. 
A

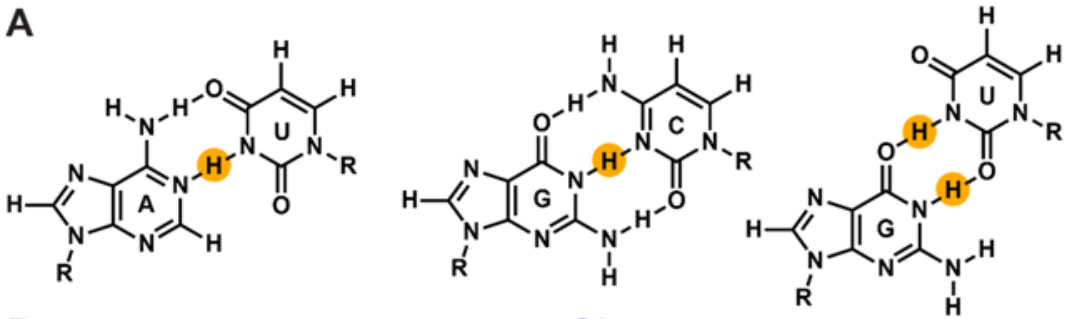<smiles>Cc1nc2sccn2c1C(=O)N1CCC(c2ccc(CN3CC(O)C3)cc2)CC1</smiles>

B

G3

7:RNA

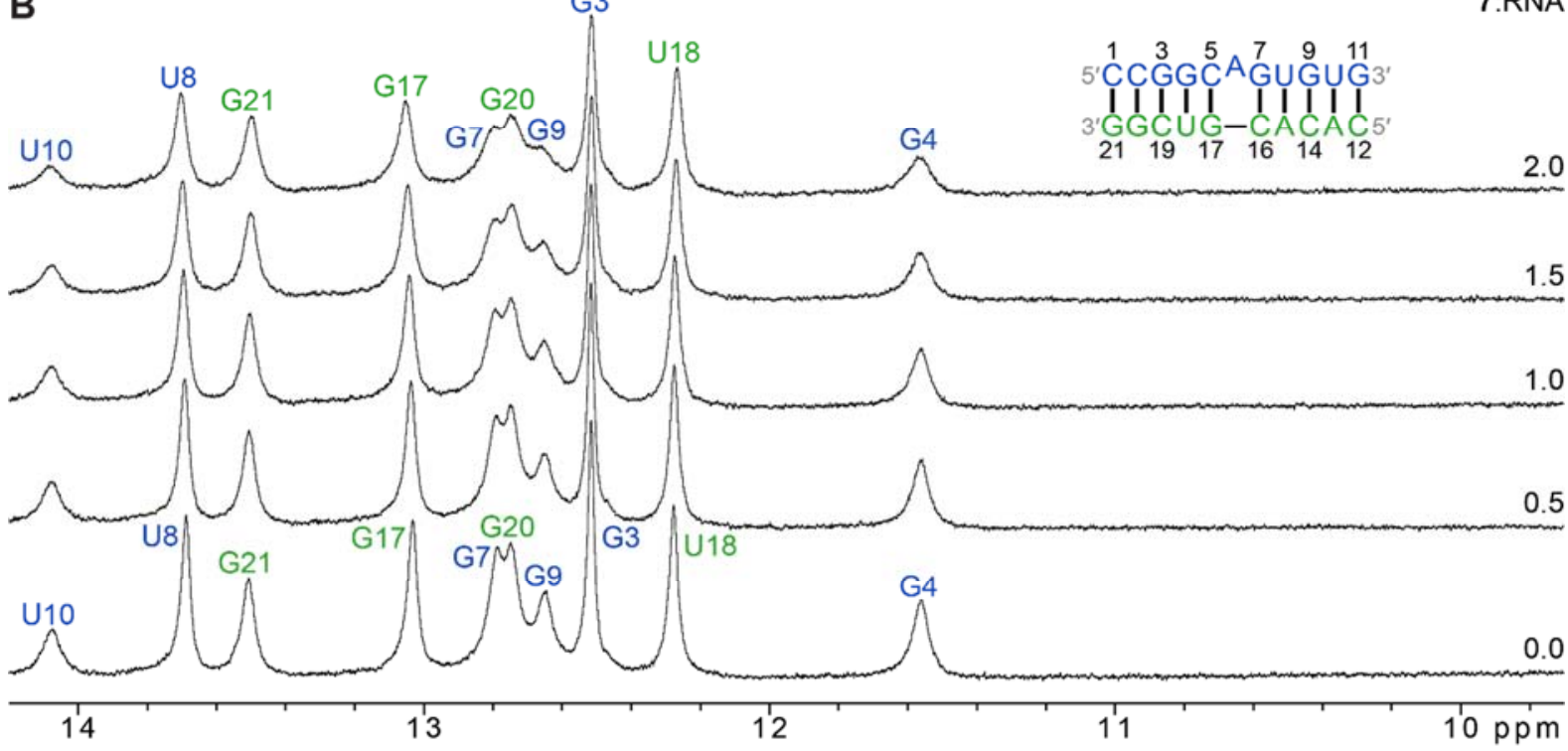

C

7:RNA

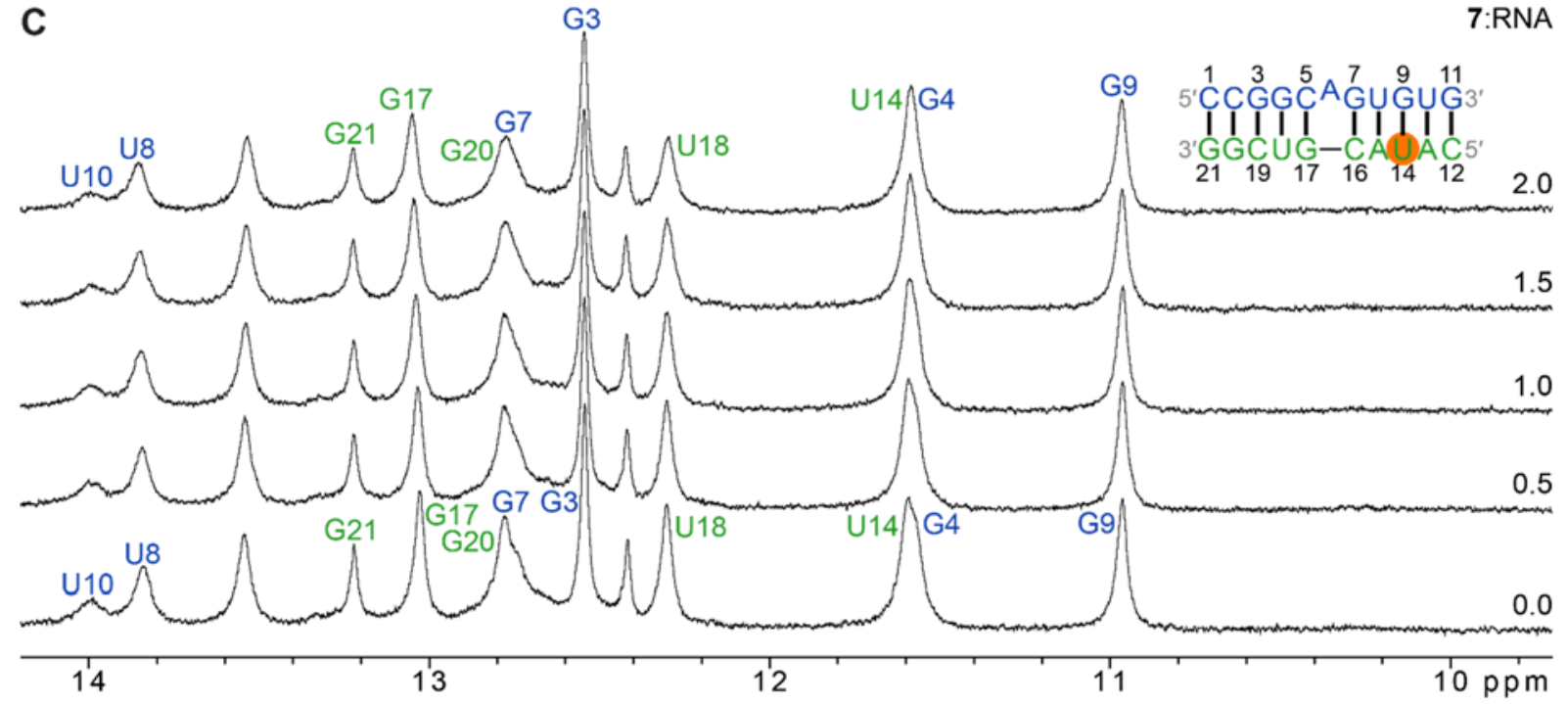

Figure S36: NMR titrations of WT and DDPAC stem mimic duplexes with 7. (A) The chemical structures of 7 and AU, GC, and GU base pairs. (B) The 1D ${ }^{1} \mathrm{H}$ NMR titration spectra of the WT stem mimic duplex with 7. (C) The 1D ${ }^{1} \mathrm{H}$ NMR titration spectra of the DDPAC stem mimic duplex with 7. The C-to-U mutation in the DDPAC construct is highlighted orange. Blue labels correspond to imino proton resonances of the top stem of the duplex and green labels correspond to the bottom stem. The molar ratio of 7 to RNA for each set of spectra is indicated on the right side. Spectra were collected at $9{ }^{\circ} \mathrm{C}$ with $150 \mu \mathrm{M}$ of RNA and 0 to $300 \mu \mathrm{M}$ of 7 at $75 \mu \mathrm{M}$ increments. 

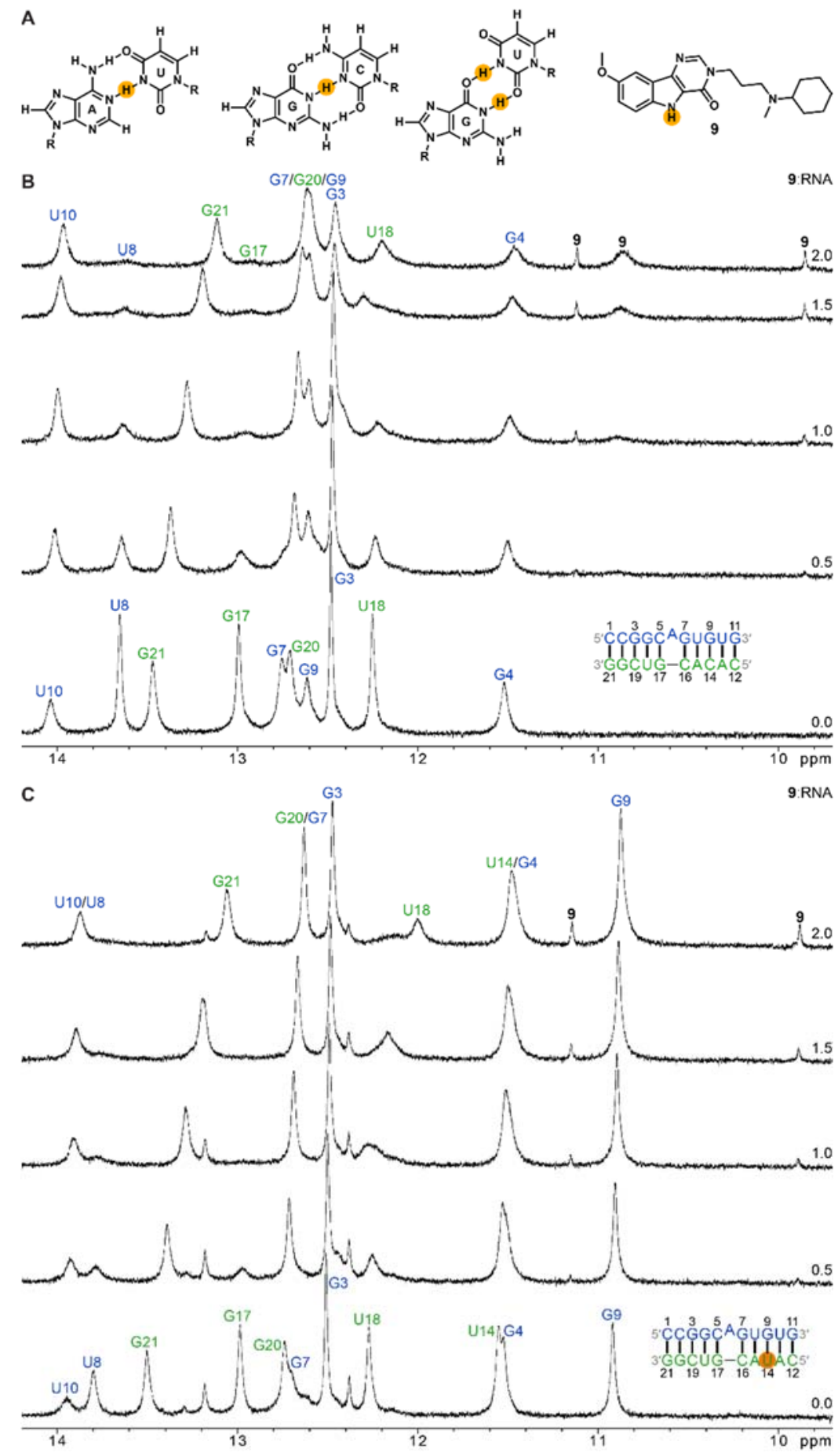

Figure S37: NMR titrations of WT and DDPAC stem mimic duplexes with 9. (A) The chemical structures of 9 and $A U, G C$, and $G U$ base pairs. Imino protons are highlighted yellow. (B) The 1D ${ }^{1} \mathrm{H}$ NMR titration spectra of the WT stem mimic duplex with 9. (C) The 1D ${ }^{1} \mathrm{H}$ NMR titration spectra of the DDPAC stem mimic duplex with 9. The C-to-U mutation in the DDPAC construct is highlighted orange. Blue labels correspond to imino proton resonances of the top stem of the duplex and green labels correspond to the bottom stem. The molar ratio of 9 to RNA for each set of spectra is indicated on the right side. Spectra were collected at $9^{\circ} \mathrm{C}$ with $100 \mu \mathrm{M}$ of RNA and 0 to $200 \mu \mathrm{M}$ of 9 at $50 \mu \mathrm{M}$ increments. 

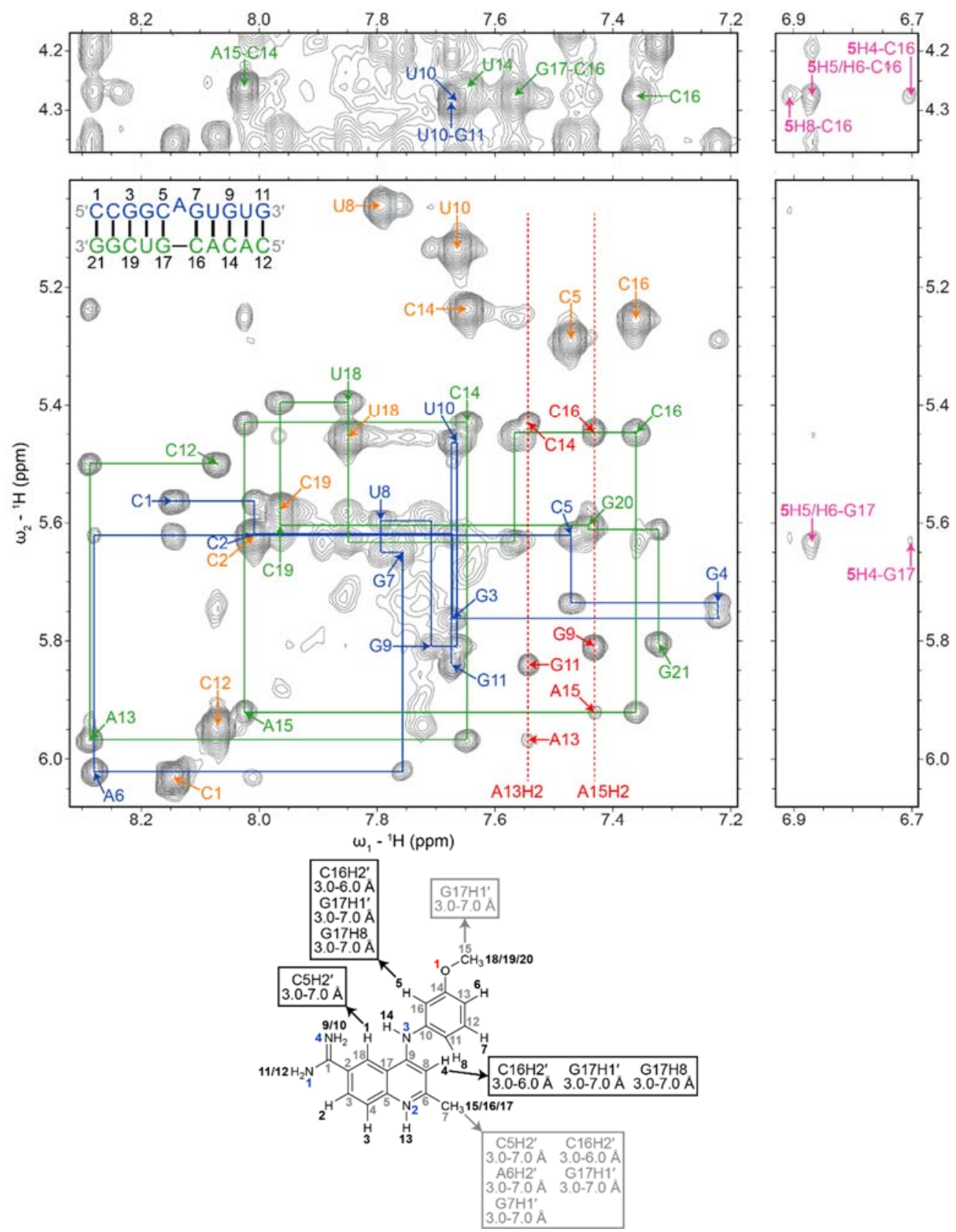

Figure S38: H6/H8-H1' region of a 2D ${ }^{1} \mathrm{H}$ NOESY NMR spectrum of the 5-WT tau RNA complex. Sequential $\mathrm{H} 6 / \mathrm{H} 8$ to $H 1$ ' walks for residues 1 to 11 and 12 to 21 are depicted with blue and green lines, respectively. Blue labels correspond to $\mathrm{H} 1^{\prime}$ to H6/H8 NOEs of residues 1 to 11 . Green labels correspond to $\mathrm{H}^{\prime}$ ' or $\mathrm{H} 2$ ' to $\mathrm{H} 6 / \mathrm{H} 8$ NOEs of residues 12 to 21. NOEs between 5 and the RNA are labeled pink. Orange labels correspond to H5 to H6 NOEs. Adenine H2 resonances are labeled red with dashed lines. In the chemical structure of $\mathbf{5}$, the numbering scheme for NMR studies is shown. Black numbers correspond to hydrogens, gray numbers correspond to carbons, blue numbers correspond to nitrogens, and a red number corresponds to oxygen. Arrows indicate hydrogens to which $\mathbf{5}$ has intermolecular NOEs and are colored according to the atoms of $\mathbf{5}$ and labeled with distances used as restraints for modeling the complex. The spectrum was acquired at $35^{\circ} \mathrm{C}$ with 400 ms mixing time and $400 \mu \mathrm{M}$ of RNA and $600 \mu \mathrm{M}$ of 5 . 

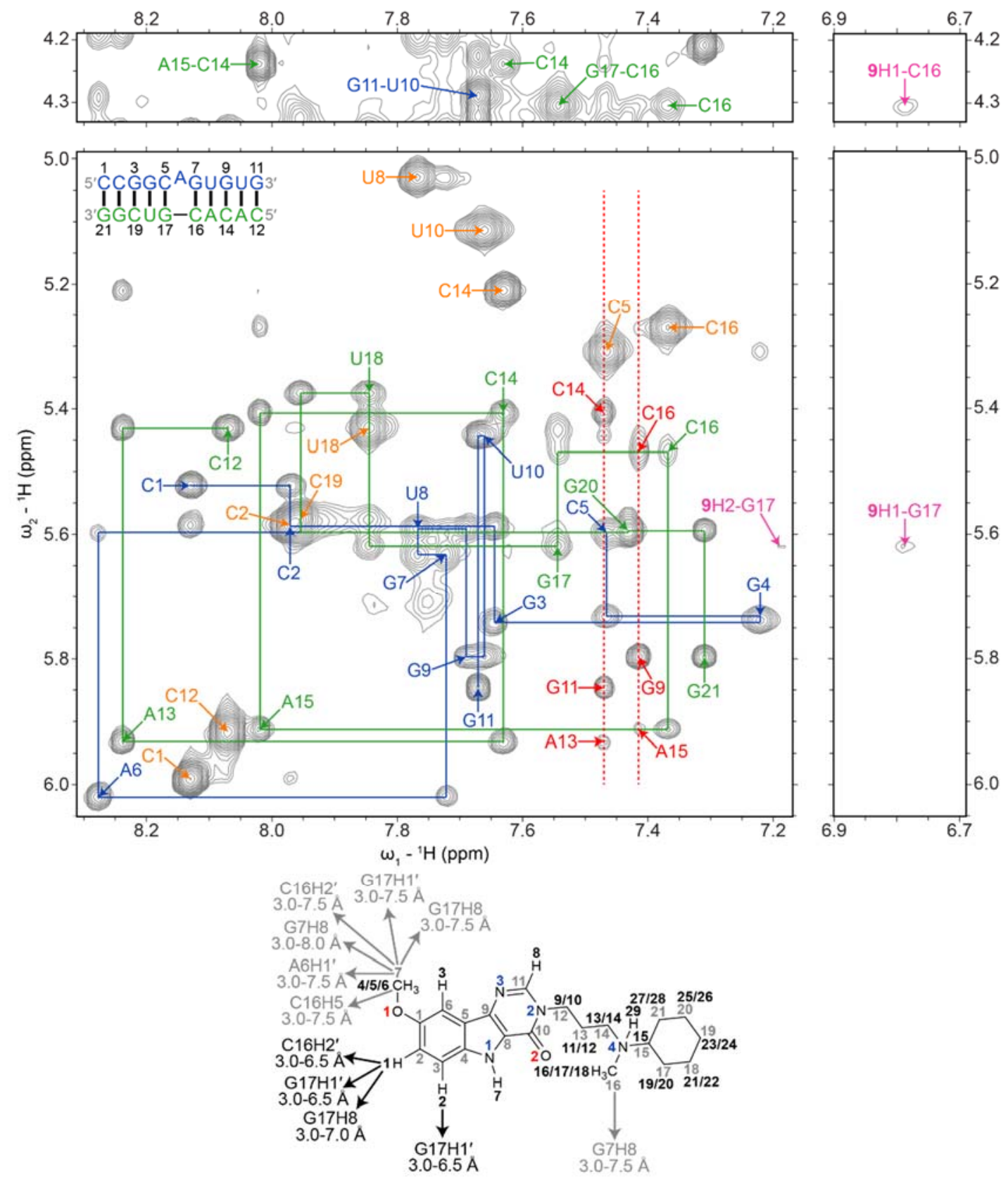

Figure S39: H6/H8-H1' region of a 2D ${ }^{1} \mathrm{H}$ NOESY NMR spectrum of the 9-WT tau RNA complex. Sequential $\mathrm{H} 6 / \mathrm{H} 8$ to $\mathrm{H} 1^{\prime}$ ' walks for residues 1 to 11 and 12 to 21 are depicted with blue and green lines, respectively. Blue labels correspond to $\mathrm{H} 1$ ' or $\mathrm{H} 2$ ' to $\mathrm{H} 6 / \mathrm{H} 8 \mathrm{NOEs}$ of residues 1 to 11. Green labels correspond to $\mathrm{H}_{1}$ ' or $\mathrm{H} 2$ ' to H6/H8 NOEs of residues 12 to 21 . NOEs between 9 and the RNA are labeled green. Orange labels correspond to H5 to H6 NOEs. Adenine $\mathrm{H} 2$ resonances are labeled red with dashed lines. In the chemical structure of 9, the numbering scheme for NMR studies is shown. Black numbers correspond to hydrogens, gray numbers correspond to carbons, blue numbers correspond to nitrogens, and red numbers corresponds to oxygens. Arrows indicate hydrogens to which $\mathbf{9}$ has intermolecular NOEs and are colored according to the atoms of $\mathbf{9}$ and labeled with distances used as restraints for modeling the complex. The spectrum was acquired at $25^{\circ} \mathrm{C}$ with $400 \mathrm{~ms}$ mixing time and $400 \mu \mathrm{M}$ of RNA and $600 \mu \mathrm{M}$ of 9. 
A

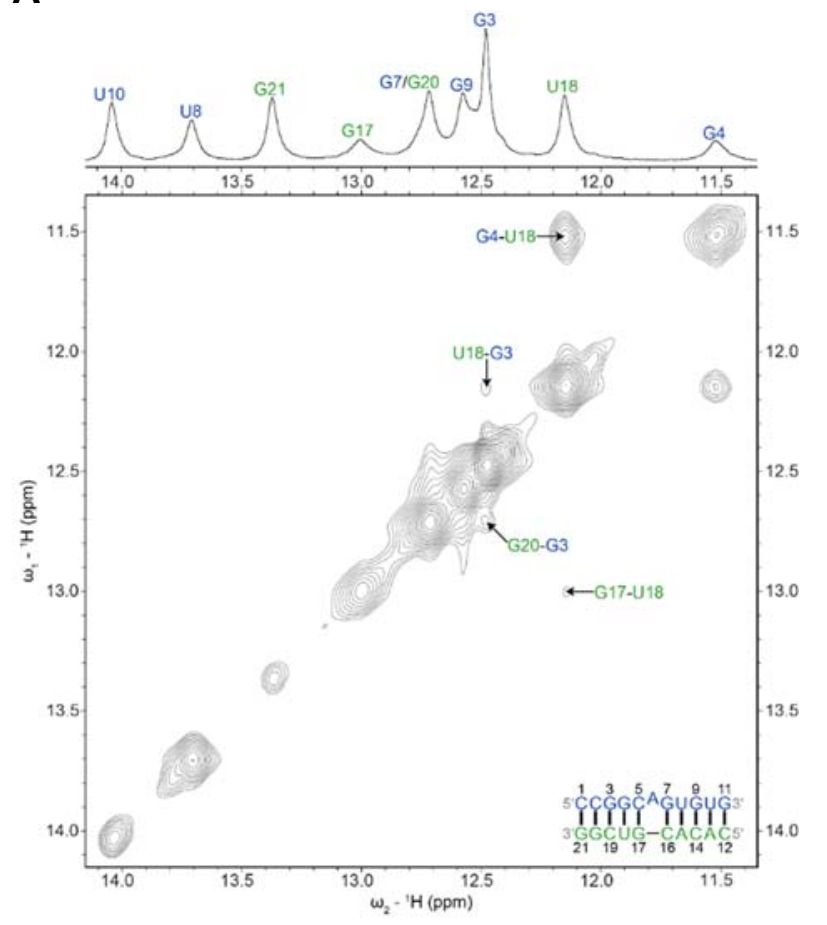

B

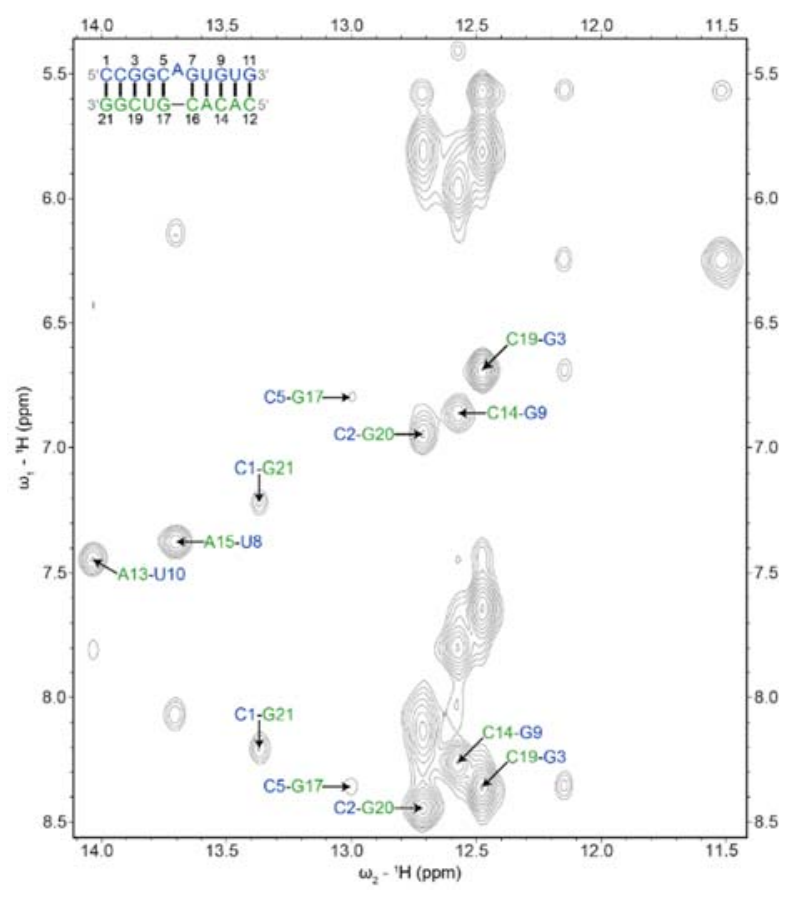

Figure S40: Imino proton regions of 1D and 2D ${ }^{1} \mathrm{H}$ NOESY NMR spectra of the WT Tau RNA duplex bound to 5. (A) Imino proton region of a 1D and a 2D proton NOESY spectrum. (B) Imino to amino/non-exchangeable proton region. Labels correspond to $\mathrm{AH} 2$ to $\mathrm{UH} 3$ and $\mathrm{GH} 1$ to $\mathrm{C}$ amino NOEs within base pairs. In each label, the first residue corresponds to $\mathrm{AH} 2$ or a $\mathrm{C}$ amino proton and the second residue corresponds to $\mathrm{UH} 3$ or $\mathrm{GH} 1$. In each spectrum, blue residues correspond to nts 1 to 11 and green residues correspond to residues 12 to 21 . 
A

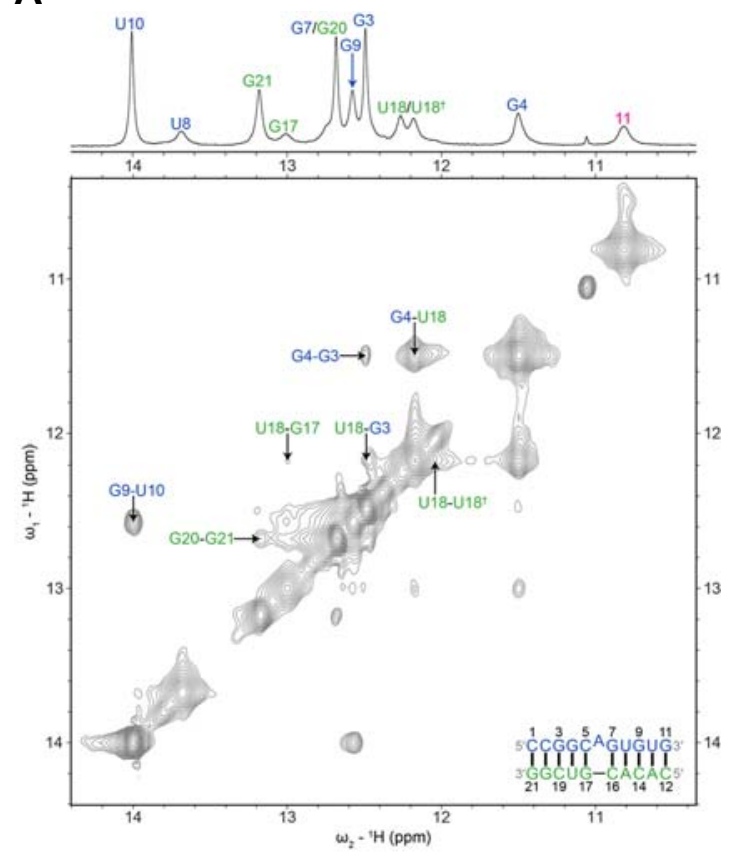

B

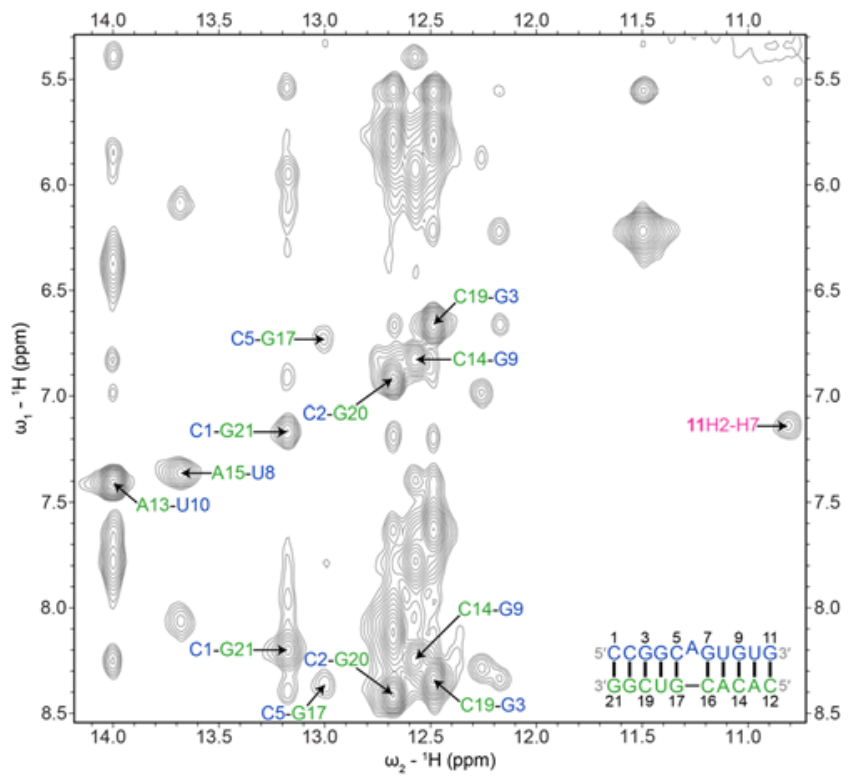

Figure S41: Imino proton regions of 1D and 2D ${ }^{1} \mathrm{H}$ NOESY NMR spectra of the WT Tau RNA duplex bound to 9. (A) Imino proton region of a 1D and a 2D proton NOESY spectrum. The resonance for 9 is labeled pink. (B) Imino to amino/non-exchangeable proton region. Labels correspond to $\mathrm{AH} 2$ to $\mathrm{UH} 3$ and $\mathrm{GH} 1$ to $\mathrm{C}$ amino NOEs within base pairs. In each label, the first residue corresponds to $\mathrm{AH} 2$ or a $\mathrm{C}$ amino proton and the second residue corresponds to $\mathrm{UH} 3$ or $\mathrm{GH} 1$. The intramolecular NOE for $\mathbf{9}$ is labeled pink. In each spectrum, blue residues correspond to nts 1 to 11 and green residues correspond to residues 12 to 21 . 


\title{
Synthesis of compounds 5-7, 9, 10, and Chem-CLIP probe 11
}

\begin{abstract}
Abbreviations;
Boc, tert-butyloxycarbonyl; DCE, dichloroethane; DCM, dichloromethane; DIPEA, N,Ndiisopropylethylamine; DMF, dimethylformamide; $\mathrm{EDCl}, \quad \mathrm{N}$-(3-dimethylaminopropyl)- $N$ ethylcarbodiimide hydrochloride; $\mathrm{HCl}$, hydrochloric acid; $\mathrm{HOBt}$, 1-hydroxybenzotriazole hydrate; IPA, isopropyl alcohol; HPLC, high performance liquid chromatography; rt, room temperature; TFA, trifluoroacetic acid.
\end{abstract}

General. Reagents and solvents were purchase from standard suppliers and used without further purification. Microwave-assisted reaction was performed by Initiator+ (Biotage). Compounds 6, 7 and 10 were purified by ISCO CombiFlash EZ Prep system with a pre-packed silica column (20$40 \mu \mathrm{m}$; RediSep Rf Gold). Compound 9 was purified by Isolera One flash chromatography system (Biotage) using pre-packed C18 column (spherical 20-35 $\mu \mathrm{m}$, Agela Technologies). Preparative HPLC purification for compound 7 and 11 was performed by HPLC (Waters 2489 and 1525) using a SunFire ${ }^{\circledR}$ Prep C18 OBD ${ }^{\mathrm{TM}} 5 \mu \mathrm{m}$ column $(19 \times 150 \mathrm{~mm})$ with a $5 \mathrm{~mL} / \mathrm{min}$ flow. HPLC purity analysis for compound 5, was performed using XB-C18 $3 \mu \mathrm{m}$ column $(3.0 \times 50 \mathrm{~mm})$ with a linear gradient $(1-5 \%$ acetonitrile/water $(0.1 \%$ TFA) in 1 minute, then $5-100 \%$ acetonitrile/water $(0.1 \%$ TFA) in $5 \mathrm{~min}$ at a flow rate of $1.2 \mathrm{~mL} / \mathrm{min}$. HPLC purity analysis for compounds $6,7,9,10$ and 11 was performed using a SunFire ${ }^{\circledR} \mathrm{C} 183.5 \mu \mathrm{m}$ column $(4.6 \times 150 \mathrm{~mm})$ with a linear gradient $(0-$ $100 \%$ methanol/water in $60 \mathrm{~min}, 0.1 \%$ TFA) at flow rate of $1 \mathrm{~mL} / \mathrm{min}$. HPLC purity $>95 \%$ for all final compounds unless otherwise indicated. NMR spectra were measured by a 400 UltraShield $^{\mathrm{TM}}$ (Bruker) $\left(400 \mathrm{MHz}\right.$ for ${ }^{1} \mathrm{H}$ and $100 \mathrm{MHz}$ for ${ }^{13} \mathrm{C}$ ) or Ascend ${ }^{\mathrm{TM}} 600$ (Bruker) $\left(600 \mathrm{MHz}\right.$ for ${ }^{1} \mathrm{H}$ and $150 \mathrm{MHz}$ for ${ }^{13} \mathrm{C}$ ). Chemical shifts are expressed in ppm relative to tetramethylsilane (TMS) for ${ }^{1} \mathrm{H}$ and residual solvent for ${ }^{13} \mathrm{C}$ as internal standards. Coupling constant ( $\mathrm{J}$ values) are reported in $\mathrm{Hz}$. High resolution mass spectra for compounds 5-7, and 10 were recorded on a Sciex TripleTOF 5600+ (Sciex, Ontario, Canada) with DuoSpray ionization source and LC system including an Agilent (Agilent Technologies, Wilmington, DE) 1200 binary pump, Agilent 1200 autosampler, Agilent 1200 column compartment, and Agilent 1200 DAD. High resolution mass spectra for compounds 9, 11, S30 and S33 were recorded on a 4800 Plus MALDI TOF/TOF Analyzer (Applied Biosystems) with a-cyano-4-hydroxycinnamic acid matrix and TOF/TOF Calibration Mixture (AB Sciex Pte. Ltd) or an Agilent 1260 Infinity LC system coupled to an Agilent 6230 TOF (HR-ESI) with a Poroshell 120 EC-C18 column (Agilent, $50 \mathrm{~mm} \times 4.6 \mathrm{~mm}, 2.7 \mu \mathrm{m}$ ).

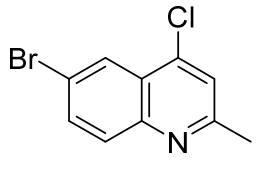

S17

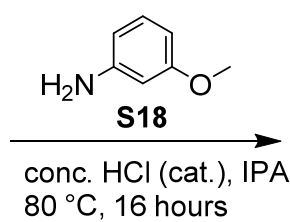

$80^{\circ} \mathrm{C}, 16$ hours

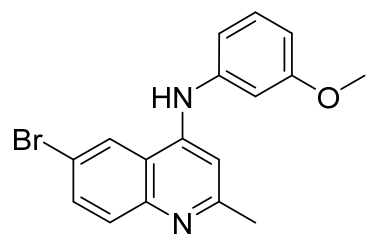

S19

\section{6-Bromo-N-(3-methoxyphenyl)-2-methylquinolin-4-amine (S19).}

3-Methoxyaniline $\mathbf{S 1 8}(500 \mathrm{mg}, 4.1 \mathrm{mmol})$ was added to a mixture of 6-bromo-4-chloro-2methylquinoline $\mathbf{S 1 7}(800 \mathrm{mg}, 3.1 \mathrm{mmol})$ in isopropanol $(10 \mathrm{~mL})$ followed by addition of concentrated hydrochloric acid $(12 \mathrm{M}, 30 \mu \mathrm{L})$. The reaction mixture was stirred at $85{ }^{\circ} \mathrm{C}$ for 16 hours, whereupon it was filtered, and the filtrate was concentrated. The resulting residue was dissolved in saturated aqueous sodium bicarbonate solution and extracted with ethyl acetate $(3 \mathrm{x}$ $100 \mathrm{~mL})$. The combined organic layers were washed with brine $(100 \mathrm{~mL})$, dried over magnesium sulfate, concentrated, and purified by column chromatography (ethyl acetate in petroleum ether) to yield 6-bromo- $N$-(3-methoxyphenyl)-2-methylquinolin-4-amine (S19) (0.92 g, 86\% yield) as 
pale-yellow solid. ${ }^{1} \mathrm{H}$ NMR $\left(400 \mathrm{MHz}, \mathrm{DMSO}-\mathrm{d}_{6}\right) \delta 8.94(\mathrm{~s}, 1 \mathrm{H}), 8.58(\mathrm{~d}, \mathrm{~J}=2.1 \mathrm{~Hz}, 1 \mathrm{H}), 7.82-$ $7.65(\mathrm{~m}, 2 \mathrm{H}), 7.33(\mathrm{t}, \mathrm{J}=8.1 \mathrm{~Hz}, 1 \mathrm{H}), 6.99-6.87(\mathrm{~m}, 3 \mathrm{H}), 6.73(\mathrm{dd}, \mathrm{J}=8.2,2.5 \mathrm{~Hz}, 1 \mathrm{H}), 3.78(\mathrm{~s}$, $3 \mathrm{H}), 2.45(\mathrm{~s}, 3 \mathrm{H})$.

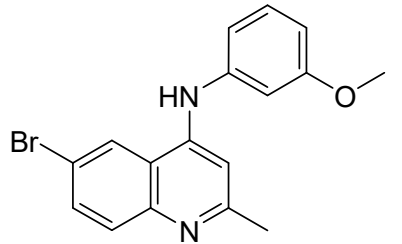

S19

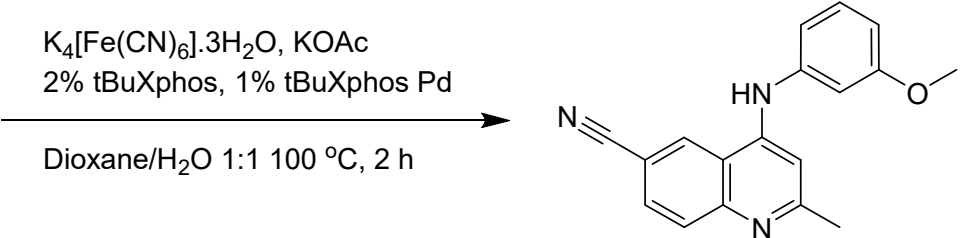

S20

4-((3-Methoxyphenyl)amino)-2-methylquinoline-6-carbonitrile (S20).

Potassium hexacyanoferrate (II) trihydrate $(430 \mathrm{mg}, 1.2 \mathrm{mmol})$ was added to a mixture of 6bromo-N-(3-methoxyphenyl)-2-methylquinolin-4-amine (S19) (800 mg, $2.3 \mathrm{mmol}), 2 \%$ tert-butyl XPhos (20 mg, $0.05 \mathrm{mmol}), 1 \%$ tert-butyl XPhos Pd G3 (19 mg, $0.02 \mathrm{mmol}$ ) and potassium acetate $(29 \mathrm{mg}, 0.29 \mathrm{mmol})$ in dioxane $(15 \mathrm{~mL})$ and $\mathrm{H}_{2} \mathrm{O}(15 \mathrm{~mL})$. The reaction was heated to 100 ${ }^{\circ} \mathrm{C}$ for 2 hours and then cooled to room temperature, whereupon water $(50 \mathrm{~mL})$ was added. The mixture was extracted with ethyl acetate $(3 \times 50 \mathrm{~mL})$. The combined organic layers were washed with brine $(150 \mathrm{~mL})$, dried over magnesium sulfate, concentrated under reduced pressure and purified by flash chromatography (ethyl acetate in petroleum ether) to yield the 4-((3methoxyphenyl)amino)-2-methylquinoline-6-carbonitrile (S20) $(560 \mathrm{mg}, 83 \%)$ as a yellow solid. ${ }^{1} \mathrm{H}$ NMR $\left(400 \mathrm{MHz}\right.$, DMSO- $\left.d_{6}\right) \delta 9.17(\mathrm{~s}, 1 \mathrm{H}), 8.95(\mathrm{~s}, 1 \mathrm{H}), 8.04-7.77(\mathrm{~m}, 2 \mathrm{H}), 7.35(\mathrm{t}, \mathrm{J}=8.1$ $\mathrm{Hz}, 1 \mathrm{H}), 7.07-6.88(\mathrm{~m}, 3 \mathrm{H}), 6.77(\mathrm{dd}, \mathrm{J}=8.3,2.5 \mathrm{~Hz}, 1 \mathrm{H}), 3.79(\mathrm{~s}, 3 \mathrm{H}), 2.49(\mathrm{~s}, 3 \mathrm{H})$.
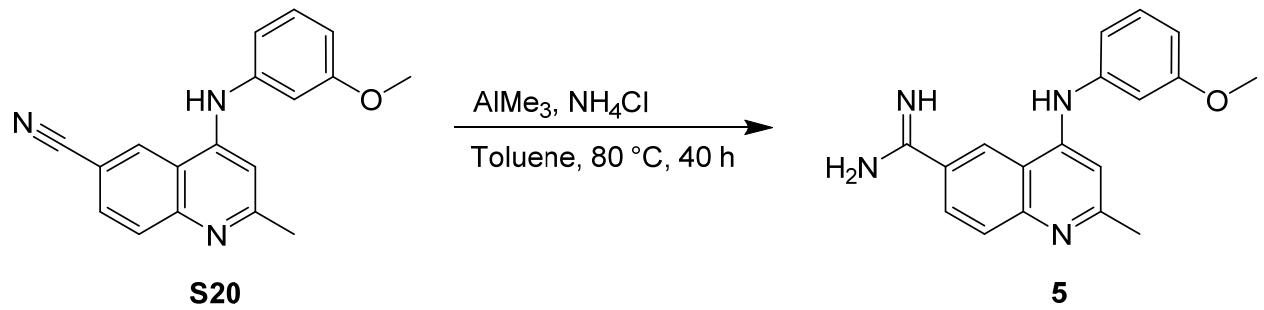

4-((3-Methoxyphenyl)amino)-2-methylquinoline-6-carboximidamide bis hydrochloride (5). Trimethyl aluminum ( $2 \mathrm{M}, 2.1 \mathrm{~mL}, 4.2 \mathrm{mmol})$ was slowly added to a mixture of ammonium chloride $(240 \mathrm{mg}, 4.5 \mathrm{mmol})$ in toluene $(2.0 \mathrm{~mL})$ at $5{ }^{\circ} \mathrm{C}$ under nitrogen. The mixture was warmed $15{ }^{\circ} \mathrm{C}$ and was stirred for 2 hours. 4-((3-Methoxyphenyl)amino)-2-methylquinoline-6-carbonitrile (S20) (200 mg, $0.69 \mathrm{mmol}$ ) was slowly added to the reaction. The mixture was stirred at $80{ }^{\circ} \mathrm{C}$ for 36 hours, whereupon it was cooled to $0{ }^{\circ} \mathrm{C}$ and quenched with methanol $(6.0 \mathrm{~mL})$. The mixture was filtered, and the filtrate was concentrated under reduced pressure. The resulting residue was purified by preparative HPLC (column: Phenomenex Synergi C18 150*30 mm*4 $\mu \mathrm{m}$; mobile phase: [water $(0.05 \% \mathrm{HCl})-\mathrm{ACN}$ ]; B\%:6\%-26\%,10 $\mathrm{min})$ to yield 4-((3-methoxyphenyl)amino)-2methylquinoline-6-carboximidamide bis hydrochloride $(5)(79 \mathrm{mg}, 30 \%)$ as a yellow solid. ${ }^{1} \mathrm{H}$ NMR $\left(400 \mathrm{MHz}, \mathrm{DMSO}-d_{6}\right) \delta 14.95(\mathrm{br} \mathrm{s}, 1 \mathrm{H}), 11.35(\mathrm{~s}, 1 \mathrm{H}), 9.79-9.66(\mathrm{~m}, 3 \mathrm{H}), 9.46(\mathrm{~s}, 2 \mathrm{H}), 8.35$ $(\mathrm{dd}, \mathrm{J}=8.9,1.8 \mathrm{~Hz}, 1 \mathrm{H}), 8.23(\mathrm{~d}, \mathrm{~J}=8.9 \mathrm{~Hz}, 1 \mathrm{H}), 7.49(\mathrm{t}, \mathrm{J}=8.0 \mathrm{~Hz}, 1 \mathrm{H}), 7.16-7.06(\mathrm{~m}, 2 \mathrm{H})$, 7.01 (dd, $\mathrm{J}=8.3,2.5 \mathrm{~Hz}, 1 \mathrm{H}), 6.95(\mathrm{~s}, 1 \mathrm{H}), 3.82(\mathrm{~s}, 3 \mathrm{H}), 2.68(\mathrm{~s}, 3 \mathrm{H}) ;{ }^{13} \mathrm{C}$ NMR $(101 \mathrm{MHz}$, DMSO$\left.d_{6}\right) \delta 164.65,160.74,157.30,154.75,141.45,138.63,132.07,131.22,126.89,125.41,120.67$, 117.03, 116.22, 113.22, 110.86, 101.90, 55.87, 20.53; HR-MS: Calcd. for C18H18N4O+ [M+H]+: 307.1554; found: 307.1556 . 


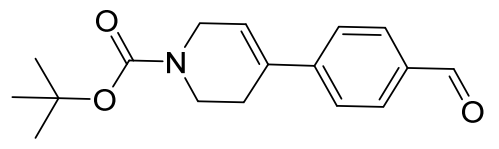

S21

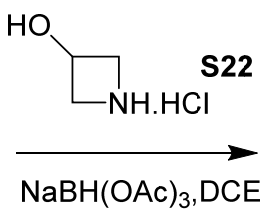

$\mathrm{NaBH}(\mathrm{OAc})_{3}, \mathrm{DCE}$

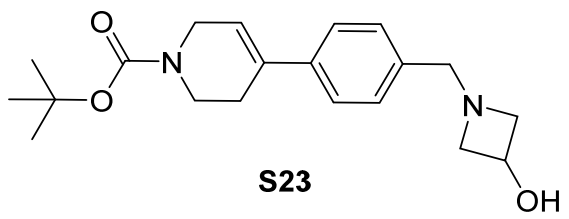

\section{tert-Butyl 4-(4-((3-hydroxyazetidin-1-yl)methyl)phenyl)-3,6-dihydropyridine-1(2H)- carboxylate (S23).}

3-Hydroxyazetidine hydrochloride $\mathbf{S 2 2}(25.2 \mathrm{~mL}, 230 \mathrm{mmol})$ was added to a solution of 1-tertbutyloxycarbonyl-4-(4-formylphenyl)-1,2,3,6-tetrahydropyridine ${ }^{12} \mathbf{S 2 1}(60 \mathrm{~g}, 0.21 \mathrm{~mol}$ ) in 1,2dichloroethane $(600 \mathrm{~mL})$ at room temperature. The reaction was stirred for 1 hour, whereupon it was cooled to $0{ }^{\circ} \mathrm{C}$. Sodium triacetoxyborohydride $(68 \mathrm{~g}, 0.32 \mathrm{~mol})$ was added in three portions, and the resulting white suspension was allowed to warm to room temperature and was stirred for 16 hours. The reaction was quenched with water $(500 \mathrm{~mL})$ and extracted with dichloromethane $(3 \times 100 \mathrm{~mL})$. The combined organic phases were washed with sodium carbonate $(2 \mathrm{M}, 1.0 \mathrm{~L})$, water $(1.0 \mathrm{~L})$ and brine $(1.0 \mathrm{~L})$, then dried over sodium sulfate and concentrated to afford a yellow oil. The oil was purified by flash chromatography (elution: dichloromethane: methanol $=10: 1$ ) to yield tert-Butyl 4-(4-((3-hydroxyazetidin-1-yl)methyl)phenyl)-3,6-dihydropyridine-1(2H)carboxylate (S23) $\left(50 \mathrm{~g}, 92 \%\right.$ purity by HPLC, 68\%) as a pale yellow oil. ${ }^{1} \mathrm{H}$ NMR $(400 \mathrm{MHz}$, Chloroform-d) $\delta 7.27$ (d, J = $8 \mathrm{~Hz}, 2 \mathrm{H}), 7.19$ (d, J = $8 \mathrm{~Hz}, 2 \mathrm{H}), 5.95$ (br. s, 1H), 4.45-4.35 (m, 1H), 4.10-3.90 (m, 2H), 3.70-3.53 (m, 6H), 3.12-3.05 (m, 2H), 2.49-2.40 (m, 2H), $1.40(\mathrm{~s}, 9 \mathrm{H})$.
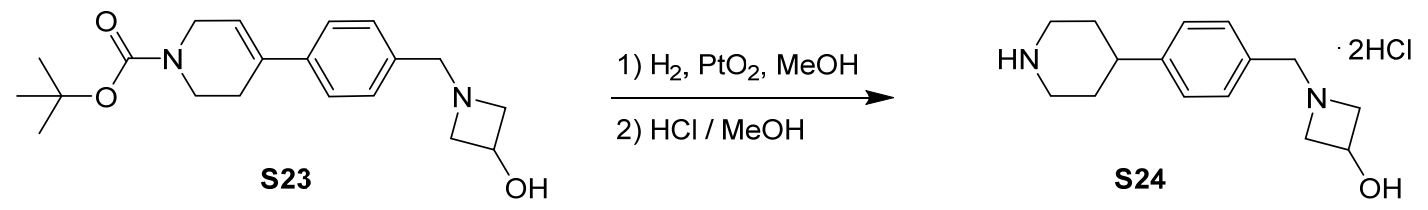

1-(4-(Piperidin-4-yl)benzyl)azetidin-3-ol bis-hydrochloride (S24).

Platinum oxide $(5.0 \mathrm{~g})$ was added to a solution of tert-butyl 4-(4-((3-hydroxyazetidin-1yl)methyl)phenyl)-3,6-dihydropyridine-1(2H)-carboxylate $\mathbf{S 2 3}(50 \mathrm{~g}, 0.15 \mathrm{~mol})$ in methanol (500 $\mathrm{mL}$ ). The reaction was stirred under $15 \mathrm{psi}$ of hydrogen at room temperature for 16 hours. The reaction mixture was filtered, and the filtrate was concentrated to afford a pale, yellow oil. Hydrochloric acid in methanol $(8.9 \mathrm{M}, 10 \mathrm{~mL})$ was added, and the solution was concentrated under reduced pressure. The residue was suspended in ethyl acetate $(250 \mathrm{~mL})$, and the suspension was stirred for 2 hours, whereupon it was filtered to afford tert-butyl 4-(4-((3hydroxyazetidin-1-yl)methyl)phenyl)piperidine-1-carboxylate hydrochloride $(48 \mathrm{~g})$ as a yellow solid that was used directly in the subsequent step without further purification. The solid material was dissolved in methanol $(400 \mathrm{~mL})$ and cooled to $0{ }^{\circ} \mathrm{C}$, whereupon hydrochloric acid in methanol $(8.9 \mathrm{M}, 100 \mathrm{~mL})$ was added. The ice-water bath was removed, and the reaction was stirred at ambient temperature for 16 hours and then concentrated to about $1 / 3$ volume. Ethyl acetate (50 $\mathrm{mL}$ ) was carefully added to crystallize a brown solid that was removed by filtration. Ethyl acetate $(500 \mathrm{~mL})$ was added to the filtrate, and the resulting suspension was allowed to stand at room temperature for 2 hours, whereupon the resulting solid was isolated by filtration to afford 1-(4(piperidin-4-yl)benzyl)azetidin-3-ol bis-hydrochloride (S24) (29 g, 61\% over two steps) as an offwhite solid. ${ }^{1} \mathrm{H}$ NMR $\left(400 \mathrm{MHz}\right.$, DMSO-d $\mathrm{d}_{6} \delta 10.96$ (br s, $\left.1 \mathrm{H}\right), 9.01$ (br s, $\left.2 \mathrm{H}\right), 7.50(\mathrm{~d}, \mathrm{~J}=8.1 \mathrm{~Hz}, 2 \mathrm{H})$, $7.28(\mathrm{~d}, \mathrm{~J}=8.1 \mathrm{~Hz}, 2 \mathrm{H}), 6.38-6.11(\mathrm{~m}, 1 \mathrm{H}),[4.70-4.59(\mathrm{~m})$ and $4.47-4.37(\mathrm{~m})$, total $1 \mathrm{H}], 4.37-4.28$ $(\mathrm{m}, 2 \mathrm{H}), 4.19-4.06(\mathrm{~m}, 2 \mathrm{H}), 3.89-3.79(\mathrm{~m}, 2 \mathrm{H}), 3.4-3.26(\mathrm{~m}, 2 \mathrm{H}$, assumed; largely obscured by water peak), $3.04-2.91(\mathrm{~m}, 2 \mathrm{H}), 2.91-2.81(\mathrm{~m}, 1 \mathrm{H}), 1.96-1.80(\mathrm{~m}, 4 \mathrm{H}) ; \mathrm{M}+\mathrm{H}=247.3 \mathrm{~m} / \mathrm{z}$. 

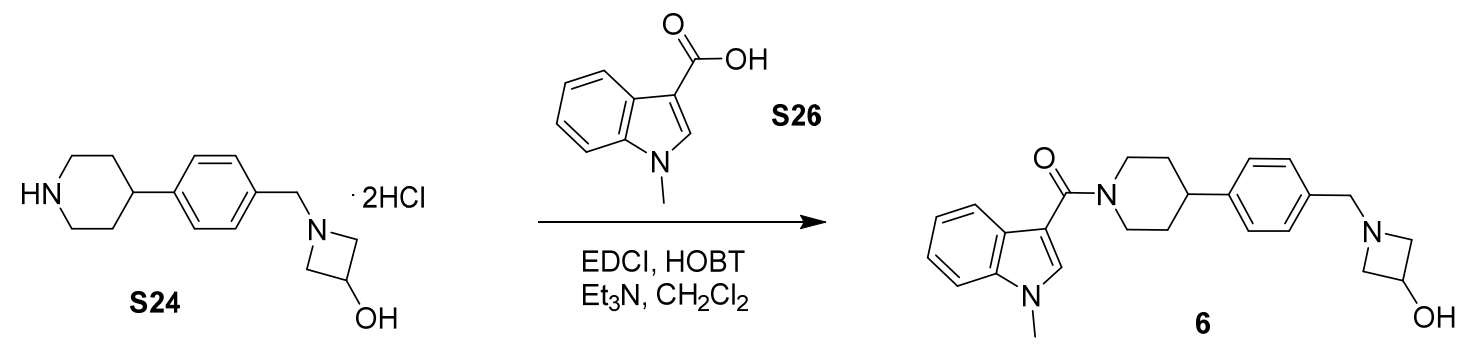

(4-(4-((3-Hydroxyazetidin-1-yl)methyl)phenyl)piperidin-1-yl)(1-methyl-1H-indol-3yl)methanone (6).

$N$-(3-Dimethylaminopropyl)- $N$ '-ethylcarbodiimide $(70 \mathrm{mg}, 0.37 \mathrm{mmol})$ was added to a solution of 1-(4-(piperidin-4-yl)benzyl)azetidin-3-ol bis-hydrochloride S24 (100 mg, $0.31 \mathrm{mmol}$ ), 1-methyl-1Hindole-3-carboxylic acid (55 mg, $0.33 \mathrm{~mol})$, 1-hydroxybenzotriazole $(70 \mathrm{mg}, 0.52 \mathrm{mmol}$ ), and triethylamine $(100 \mu \mathrm{L}, 0.72 \mathrm{mmol})$ in dichloromethane $(3 \mathrm{~mL})$. The mixture was stirred at room temperature for 65 hours. Ethyl acetate $(30 \mathrm{~mL})$ was added, and the mixture was etracted with $1 \mathrm{~N}$ aqueous hydrochloric acid $(8 \mathrm{~mL})$. The acid layer was adjusted to $\mathrm{pH}$ of 9 using aqueous $2 \mathrm{~N}$ sodium hydroxide solution and extracted with ethyl acetate $(30 \mathrm{~mL})$. The organic layer was washed with brine $(5 \mathrm{~mL})$, dried over magnesium sulfate and concentrated under reduced pressure. The residue was purified by column chromatography $(5-10 \%$ methanol in dichloromethane with $0.1 \%$ ammonium hydroxide) to afford (4-(4-((3-hydroxyazetidin-1yl)methyl)phenyl)piperidin-1-yl)(1-methyl-1H-indol-3-yl)methanone (6) $(48 \mathrm{mg}, 38 \%)$ as a white solid. HPLC purity $=94 \%{ }^{1} \mathrm{H}$ NMR $(400 \mathrm{MHz}$, Chloroform- $d) \delta 7.71(\mathrm{~d}, \mathrm{~J}=7.9 \mathrm{~Hz}, 1 \mathrm{H}), 7.45(\mathrm{~s}$, $1 \mathrm{H}), 7.35(\mathrm{~d}$, component of $A B$ quartet, $\mathrm{J}=8.3 \mathrm{~Hz}, 1 \mathrm{H}), 7.31-7.25(\mathrm{~m}, 1 \mathrm{H}), 7.25-7.19(\mathrm{~m}, 3 \mathrm{H})$, 7.18 (d, component of $A B$ quartet, $\mathrm{J}=8.2 \mathrm{~Hz}, 2 \mathrm{H}), 4.64-4.50(\mathrm{~m}, 2 \mathrm{H}), 4.45(\mathrm{p}, \mathrm{J}=5.9 \mathrm{~Hz}, 1 \mathrm{H})$, $3.83(\mathrm{~s}, 3 \mathrm{H}), 3.64(\mathrm{td}, \mathrm{J}=6.2,2.1 \mathrm{~Hz}, 2 \mathrm{H}), 3.60(\mathrm{~s}, 2 \mathrm{H}), 3.06(\mathrm{br} \mathrm{t}, \mathrm{J}=12.8 \mathrm{~Hz}, 2 \mathrm{H}), 2.94(\mathrm{td}, \mathrm{J}=$ 5.9, 2.1 Hz, 2H), $2.83-2.72(\mathrm{~m}, 1 \mathrm{H}), 1.89(\mathrm{br} \mathrm{d}, \mathrm{J}=13 \mathrm{~Hz}, 2 \mathrm{H}), 1.81-1.6(\mathrm{~m}, 2 \mathrm{H}$, assumed; partially obscured by water peak); ${ }^{13} \mathrm{C}$ NMR $(101 \mathrm{MHz}$, Chloroform-d) $\delta 166.65,144.36,136.46$, 136.09, 131.57, 128.70, 126.81, 126.09, 122.38, 120.84, 120.61, 110.81, 109.77, 64.17, 63.43, 62.68, 45.94, 42.61, 33.73, 33.15; HR-MS: Calcd. for $\mathrm{C}_{25} \mathrm{H}_{29} \mathrm{~N}_{3} \mathrm{O}_{2}+[\mathrm{M}+\mathrm{H}]+$ : 404.2329; found: 404.2333 .
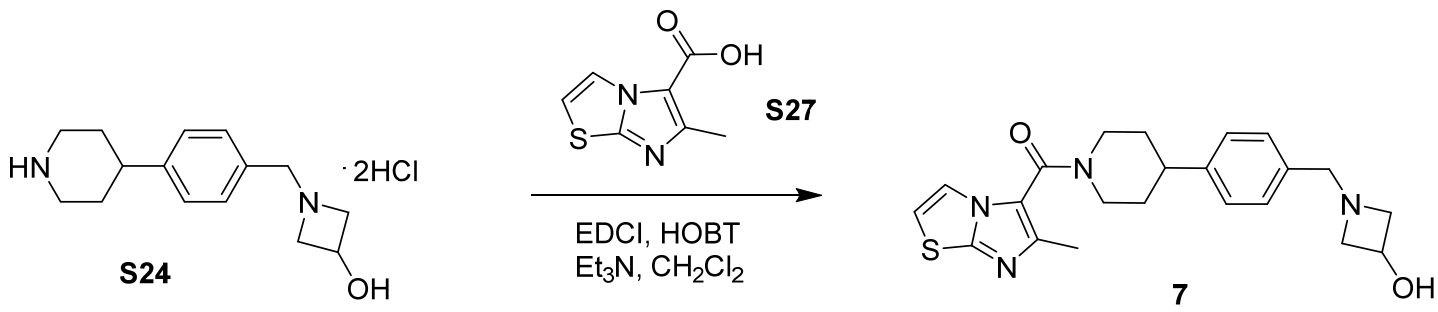

\section{(4-(4-((3-hydroxyazetidin-1-yl)methyl)phenyl)piperidin-1-yl)(6-methylimidazo[2,1-b]thiazol-} 5-yl)methanone (7).

$\mathrm{N}$-(3-Dimethylaminopropyl)- $N$ '-ethylcarbodiimide $(70 \mathrm{mg}, 0.37 \mathrm{mmol})$ was added to a solution of 1-(4-(piperidin-4-yl)benzyl)azetidin-3-ol bis-hydrochloride $\mathbf{S 2 4}$ (100 mg, $0.31 \mathrm{mmol}$ ), 6methylimidazo[2,1-b]thiazole-5-carboxylic acid $\mathbf{S} 27$ (60 $\mathrm{mg}, 0.33 \mathrm{~mol}$ ), 1-hydroxybenzotriazole (70 mg, $0.52 \mathrm{mmol})$, and triethylamine $(100 \mu \mathrm{L}, 0.72 \mathrm{mmol})$ in dichloromethane $(3 \mathrm{~mL})$. The mixture was stirred at ambient temperature for 65 hours. Ethyl acetate $(30 \mathrm{~mL})$ was added, and the mixture was extracted with $1 \mathrm{~N}$ aqueous hydrochloric acid $(8 \mathrm{~mL})$. The acid layer was adjusted to $\mathrm{pH}$ of 9 using $2 \mathrm{~N}$ aqueous sodium hydroxide solution and extracted with ethyl acetate $(30 \mathrm{~mL})$. The organic layer was washed with brine $(5 \mathrm{~mL})$, dried over magnesium sulfate, concentrated 
under reduced pressure. The residue was purified by column chromatography $(5-10 \%$ methanol in dichloromethane with $0.1 \%$ ammonium hydroxide) to afford (4-(4-((3-hydroxyazetidin-1yl)methyl)phenyl)piperidin-1-yl)(6-methylimidazo[2,1-b]thiazol-5-yl)methanone (7) (65 mg, 50\%) as a white solid ( $84 \%$ purity by HPLC). The compound was further purified by HPLC (0-60\% methanol/water in $60 \mathrm{~min}, 0.1 \%$ TFA) to afford compound 7 as the TFA salt: ${ }^{1} \mathrm{H}$ NMR $(600 \mathrm{MHz}$, $\left.\mathrm{CD}_{3} \mathrm{OD}\right): \delta=7.96(\mathrm{~m}, 1 \mathrm{H}), 7.47(\mathrm{~d}, \mathrm{~J}=4.4 \mathrm{~Hz}, 1 \mathrm{H}), 7.44-7.36(\mathrm{~m}, 4 \mathrm{H}), 4.73-4.55(\mathrm{~m}, 1 \mathrm{H}), 4.46-$ $4.20(\mathrm{~m}, 6 \mathrm{H}), 3.98-3.88(\mathrm{~m}, 2 \mathrm{H}), 3.33-3.17(\mathrm{~m}, 2 \mathrm{H}$, partially overlapped with solvent peak), 2.96 $(\mathrm{m}, 1 \mathrm{H}), 2.50(\mathrm{~s}, 3 \mathrm{H}), 1.99-1.91(\mathrm{~m}, 2 \mathrm{H}), 1.81-1.70(\mathrm{~m}, 2 \mathrm{H}) \cdot{ }^{13} \mathrm{C}$ NMR $\left(150 \mathrm{MHz}, \mathrm{CD}_{3} \mathrm{OD}\right): \delta=$ 161.6, 150.8, 148.7, 148.7, 141.6, 131.4, 131.3, 129.7, 129.5, 129.0, 122.2, 119.7, 117.3, 64.2, $63.7,61.8,60.4,60.0,58.9,46.9,43.4,34.4,13.5$. The TFA salt of compound 7 was dissolved in dichloromethane, and the solution was washed with saturated aqueous sodium bicarbonate solution and brine. The organic phase was dried over sodium sulfate concentrated under reduced pressure to afford (4-(4-((3-hydroxyazetidin-1-yl)methyl)phenyl)piperidin-1-yl)(6methylimidazo[2,1-b]thiazol-5-yl)methanone (7) as the free base: ${ }^{1} \mathrm{H}$ NMR $\left(600 \mathrm{MHz}, \mathrm{CDCl}_{3}\right): \delta=$ $7.73(\mathrm{~d}, \mathrm{~J}=4.5 \mathrm{~Hz}, 1 \mathrm{H}), 7.24-7.19(\mathrm{~m}, 2 \mathrm{H}), 7.19-7.15(\mathrm{~m}, 2 \mathrm{H}), 6.84(\mathrm{~d}, \mathrm{~J}=4.5 \mathrm{~Hz}, 1 \mathrm{H}), 4.46(\mathrm{~m}$, $1 \mathrm{H})$, 4.43-4.33 (m, 2H), 3.67-3.62 (m, 2H), $3.60(\mathrm{~s}, 2 \mathrm{H}), 3.16-3.03(\mathrm{~m}, 2 \mathrm{H}), 2.98-2.90(\mathrm{~m}, 2 \mathrm{H})$, 2.84-2.76 $(\mathrm{m}, 1 \mathrm{H}), 2.43(\mathrm{~s}, 3 \mathrm{H}), 2.00-1.92(\mathrm{~m}, 2 \mathrm{H}), 1.77-1.67(\mathrm{~m}, 2 \mathrm{H})$. HR-MS: Calcd. for $\mathrm{C}_{22} \mathrm{H}_{26} \mathrm{~N}_{4} \mathrm{O}_{2} \mathrm{~S}^{+}[\mathrm{M}+\mathrm{H}]^{+}:$411.1849; found: 411.1853 .
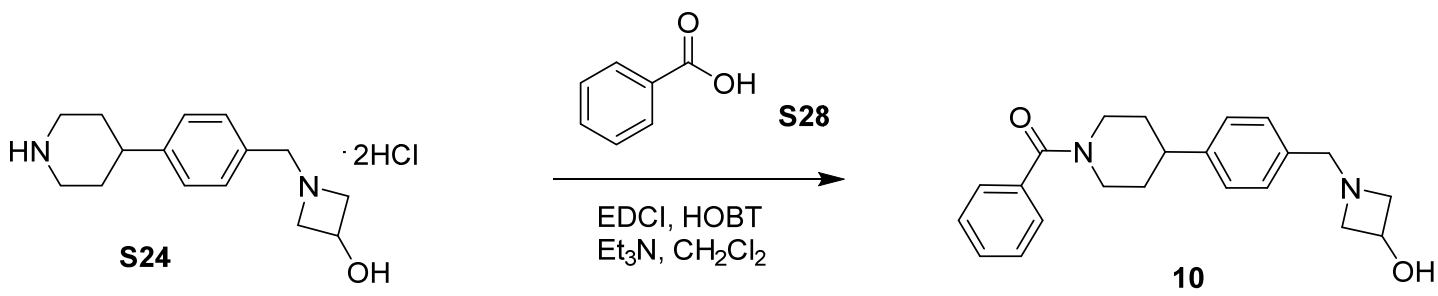

(4-(4-((3-Hydroxyazetidin-1-yl)methyl)phenyl)piperidin-1-yl)(phenyl)methanone (10).

$N$-(3-Dimethylaminopropyl)- $N$ '-ethylcarbodiimide $(65 \mathrm{mg}, 0.34 \mathrm{mmol})$ was added to a solution of 1-(4-(piperidin-4-yl)benzyl)azetidin-3-ol bis-hydrochloride $\mathbf{S 2 4}$ (100 $\mathrm{mg}, 0.31 \mathrm{mmol})$, benzoic acid S28 (42 mg, $0.34 \mathrm{mmol})$, 1-hydroxybenzotriazole $(65 \mathrm{mg}, 0.48 \mathrm{mmol}$ ) and triethylamine (100 uL, $0.72 \mathrm{mmol}$ ) in dichloromethane $(1 \mathrm{~mL})$. The reaction was stirred at room temperature for 3 hours, whereupon ethyl acetate $(30 \mathrm{~mL})$ was added. The mixture was washed with water $(5 \mathrm{~mL})$ and brine $(5 \mathrm{~mL})$, and the organic layer was dried over magnesium sulfate and concentrated. The residue was purified by column chromatography (5-10\% methanol in dichloromethane with $0.1 \%$ ammonium hydroxide) to yield (4-(4-((3-hydroxyazetidin-1-yl)methyl)phenyl)piperidin-1$\mathrm{yl})$ (phenyl)methanone (10) $(19 \mathrm{mg}, 18 \%)$ as a white solid. HPLC purity $=94 \%$. On the basis of NMR analysis, Compound 8 was assumed to exist as rotamers in solution. ${ }^{1} \mathrm{H}$ NMR $(400 \mathrm{MHz}$, Chloroform- $d$ ) $\delta 7.46-7.37(\mathrm{~m}, 5 \mathrm{H}), 7.21$ (d, component of AB quartet, $J=8.1 \mathrm{~Hz}, 2 \mathrm{H}), 7.16(\mathrm{~d}$, component of $A B$ quartet, $\mathrm{J}=8.1 \mathrm{~Hz}, 2 \mathrm{H}$ ), $4.87(\mathrm{br} \mathrm{s}, 1 \mathrm{H}), 4.43$ (pentet, $\mathrm{J}=5.9 \mathrm{~Hz}, 1 \mathrm{H}$ ), $3.98-$ $3.77(\mathrm{~m}, 1 \mathrm{H}), 3.68-3.57(\mathrm{~m}, 4 \mathrm{H}), 3.20-2.81(\mathrm{~m}, 5 \mathrm{H}), 2.76(\mathrm{tt}, \mathrm{J}=12.1,3.7 \mathrm{~Hz}, 1 \mathrm{H}), 2.05-1.51$ $(\mathrm{m}, 4 \mathrm{H}) .{ }^{13} \mathrm{C}$ NMR $(101 \mathrm{MHz}$, Chloroform-d) $\delta 170.57,144.27,136.32,135.88,129.71,128.92$, 128.61, 127.00, 126.92, 64.18, 63.29, 62.63, 48.54, 42.96, 42.56, 34.03, 33.07. HR-MS: Calcd. for $\mathrm{C}_{22} \mathrm{H}_{27} \mathrm{~N}_{2} \mathrm{O}_{2}+[\mathrm{M}+\mathrm{H}]^{+}:$351.2067; found 351.2078. 


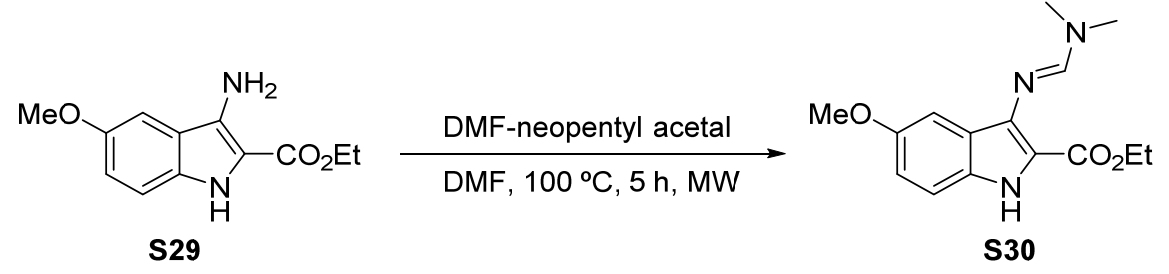

Ethyl (E)-3-(((dimethylamino)methylene)amino)-5-methoxy-1H-indole-2-carboxylate (S30) A solution of ethyl 3-amino-5-methoxy-1H-indole-2-carboxylate $\mathbf{S 2 9}(117 \mathrm{mg}, 0.5 \mathrm{mmol})$ and DMF-neopentyl acetal $(488 \mu \mathrm{L}, 1.8 \mathrm{mmol})$ in DMF $(5 \mathrm{~mL})$ was heated at $100{ }^{\circ} \mathrm{C}$ for 5 hours by microwave. After cooling to room temperature, solvent was evaporated to give ethyl $(E)$-3(((dimethylamino)methylene)amino)-5-methoxy-1H-indole-2-carboxylate (S30) (145 mg). The crude material was used in the next reaction without further purification. ${ }^{1} \mathrm{H}$ NMR $(400 \mathrm{MHz}$, $\left.\mathrm{CDCl}_{3}\right) \delta 8.24(\mathrm{br} \mathrm{s}, 1 \mathrm{H}), 7.77(\mathrm{~s}, 1 \mathrm{H}), 7.18(\mathrm{~d}, \mathrm{~J}=8.9 \mathrm{~Hz}, 1 \mathrm{H}), 7.10(\mathrm{~s}, 1 \mathrm{H}), 6.97(\mathrm{~m}, 1 \mathrm{H}), 4.32$ $(\mathrm{q}, \mathrm{J}=7.1 \mathrm{~Hz}, 2 \mathrm{H}), 3.85(\mathrm{~s}, 3 \mathrm{H}), 3.22-2.97(\mathrm{~m}, 6 \mathrm{H}), 1.36(\mathrm{t}, \mathrm{J}=7.1 \mathrm{~Hz}, 3 \mathrm{H}) ;{ }^{13} \mathrm{C}$ NMR $(100 \mathrm{MHz}$, $\left.\mathrm{CDCl}_{3}\right) \delta 162.4,156.4,153.8,137.8,130.9,124.7,117.8,114.6,112.4,101.0,60.1,55.7,40.2$, 34.3, 14.4; HR-MS (MALDI): Calcd. for $\mathrm{C}_{15} \mathrm{H}_{20} \mathrm{~N}_{3} \mathrm{O}_{3}{ }^{+}[\mathrm{M}+\mathrm{H}]^{+}:$290.1499; found: 290.1491.
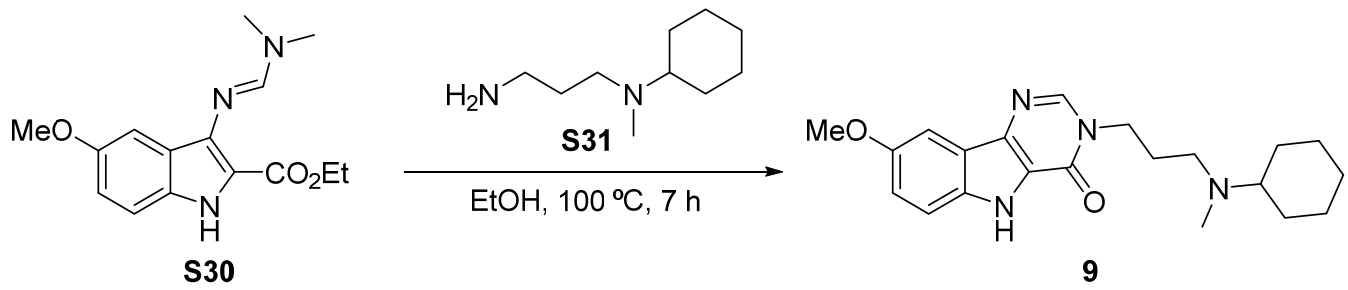

\section{3-(3-(Cyclohexyl(methyl)amino)propyl)-8-methoxy-3,5-dihydro-4H-pyrimido[5,4-b]indol-4- one (9).}

To a solution of $(E)-3-((($ dimethylamino)methylene)amino $)-5$-methoxy-1H-indole-2-carboxylate S30 $(116 \mathrm{mg}, 0.4 \mathrm{mmol})$ in ethanol $(0.5 \mathrm{~mL})$ was added $N^{1}$-cyclohexyl- $N^{1}$-methylpropane-1,3diamine $\mathbf{S} 31$ (204 mg, $1.2 \mathrm{mmol}$ ), and the reaction was heated at $100{ }^{\circ} \mathrm{C}$ for 7 hours. After cooling to room temperature, the reaction mixture was poured into water, and the resulting solid was isolated by filtration and washed with water. The crude material was purified by $\mathrm{C} 18$ reversephase column chromatography (50-70\% methanol/water, $0.1 \%$ TFA). The fractions containing the desired product were combined and concentrated under reduced pressure, and the remaining aqueous solution was extracted with dichloromethane after the solution was basified by addition of saturated aqueous solution of sodium bicarbonate. The organic layer was washed with brine, dried over sodium sulfate and concentrated to afford 3-(3-(cyclohexyl(methyl)amino)propyl)-8methoxy-3,5-dihydro-4H-pyrimido[5,4-b]indol-4-one (9) as a white solid (125.7 $\mathrm{mg}, 0.34 \mathrm{mmol}$, 85\%). ${ }^{1} \mathrm{H}$ NMR (600 MHz, $\left.\mathrm{CDCl}_{3}\right) \delta 11.00(\mathrm{~s}, 1 \mathrm{H}), 8.12(\mathrm{~s}, 1 \mathrm{H}), 7.56(\mathrm{~d}, \mathrm{~J}=2.5 \mathrm{~Hz}, 1 \mathrm{H}), 7.53$ (dd, $\mathrm{J}=8.9,0.4 \mathrm{~Hz}, 1 \mathrm{H}), 7.17(\mathrm{dd}, \mathrm{J}=8.9,2.5 \mathrm{~Hz}, 1 \mathrm{H}), 4.28(\mathrm{t}, \mathrm{J}=6.8 \mathrm{~Hz}, 2 \mathrm{H}), 3.91(\mathrm{~s}, 3 \mathrm{H}), 2.54(\mathrm{t}$, $\mathrm{J}=6.6 \mathrm{~Hz}, 2 \mathrm{H}), 2.38(\mathrm{~m}, 1 \mathrm{H}), 2.25(\mathrm{~s}, 3 \mathrm{H}), 2.07(\mathrm{~m}, 2 \mathrm{H}), 1.84-1.72(\mathrm{~m}, 4 \mathrm{H}), 1.62(\mathrm{~m}, 1 \mathrm{H}), 1.30-$ $1.17(\mathrm{~m}, 4 \mathrm{H}), 1.07(\mathrm{~m}, 1 \mathrm{H}) ;{ }^{13} \mathrm{C}$ NMR $\left(150 \mathrm{MHz}, \mathrm{CDCl}_{3}\right) \delta$ 155.3, 154.7, 143.1, 138.5, 134.7, 122.7, 121.7, 119.3, 113.7, 100.6, 62.8, 55.7, 50.0, 44.9, 36.7, 28.4, 27.2, 26.3, 26.1; HR-MS (MALDI): Calcd. for $\mathrm{C}_{21} \mathrm{H}_{29} \mathrm{~N}_{4} \mathrm{O}_{2}{ }^{+}[\mathrm{M}+\mathrm{H}]^{+}:$369.2285; found: 369.2293 . 

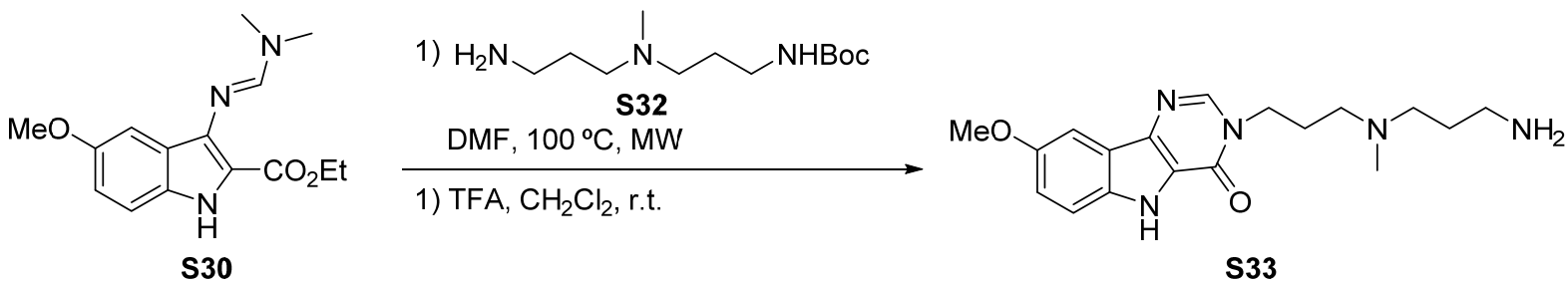

\section{3-(3-((3-aminopropyl)(methyl)amino)propyl)-8-methoxy-3,5-dihydro-4H-pyrimido[5,4- b]indol-4-one (S33)}

A mixture of ethyl (E)-3-(((dimethylamino)methylene)amino)-5-methoxy-1H-indole-2-carboxylate S30 (300 mg, $1.04 \mathrm{mmol})$ and tert-butyl (3-((3-aminopropyl)(methyl)amino)-propyl)carbamate $(229 \mathrm{mg}, 1.56 \mathrm{mmol})$ in DMF $(1.0 \mathrm{~mL})$ was heated at $100{ }^{\circ} \mathrm{C}$ for 2 hours in a microwave reactor. This mixture was allowed to cool to room temperature, whereupon it was concentrated under reduced pressure. The residue was dissolved into $2 \mathrm{~mL}$ of TFA:dichloromethane (1:1) and the mixture was stirred at room temperature overnight. This mixture was concentrated under reduced pressure, and the crude material was purified by C18 column chromatography $(120 \mathrm{~g}, 2-80 \%$ methanol/water, 0.1\% TFA) to afford 3-(3-((3-aminopropyl)(methyl)amino)propyl)-8-methoxy-3,5dihydro-4H-pyrimido[5,4-b]indol-4-one (S33) $(412 \mathrm{mg}, 70 \%)$. ${ }^{1} \mathrm{H}$ NMR $\left(600 \mathrm{MHz}, \mathrm{DMSO}-d_{6}\right) \delta$ $12.0(\mathrm{~s}, 1 \mathrm{H}), 9.72(\mathrm{~s}, 1 \mathrm{H}), 8.29(\mathrm{~s}, 1 \mathrm{H}), 7.94-7.82(\mathrm{~m}, 3 \mathrm{H}), 7.46(\mathrm{~d}, \mathrm{~J}=9.0 \mathrm{~Hz}, 1 \mathrm{H}), 7.42(\mathrm{~d}, \mathrm{~J}=$ $2.5 \mathrm{~Hz}, 1 \mathrm{H}), 7.13(\mathrm{dd}, \mathrm{J}=9.0,2.5 \mathrm{~Hz}, 1 \mathrm{H}), 4.17(\mathrm{t}, \mathrm{J}=6.9 \mathrm{~Hz}, 2 \mathrm{H}), 3.84(\mathrm{~s}, 3 \mathrm{H}), 3.25-3.04(\mathrm{~m}$, $4 \mathrm{H}), 2.91-2.82(\mathrm{~m}, 2 \mathrm{H}), 2.78(\mathrm{~s}, 3 \mathrm{H}), 2.21-2.11(\mathrm{~m}, 2 \mathrm{H}), 1.98-1.85(\mathrm{~m}, 2 \mathrm{H}){ }^{13} \mathrm{C}$ NMR $(150 \mathrm{MHz}$, $\left.\mathrm{CDCl}_{3}\right) \delta 156.4,144.5,136.2,123.3,122.2,120.6,118.5,116.6,114.8,101.5,56.1,54.9,54.3$, 44.5, 40.4, 37.7, 25.8, 23.5; HR-MS (ESI): Calcd for $\mathrm{C}_{18} \mathrm{H}_{26} \mathrm{~N}_{5} \mathrm{O}_{2}{ }^{+}, 344.2081$; found, 344.2070.<smiles>C#CCCCC1(CCC(=O)O)N=NCC1(CCC#C)CCC(=O)NCCCN(C)CCCn1cnc2c([nH]c3ccc(OC)cc32)c1=O</smiles>

3-(3-(but-3-yn-1-yl)-3H-diazirin-3-yl)-N-(3-((3-(8-methoxy-4-oxo-4,5-dihydro-3Hpyrimido[5,4-b]indol-3-yl)propyl)(methyl)amino)propyl)propenamide (11)

To a mixture of 3-(3-(but-3-yn-1-yl)-3H-diazirin-3-yl)propanoic acid S34 (19.6 mg, $118 \mu \mathrm{mol}), \mathrm{N}$ (3-dimethylaminopropyl)- $N$ '-ethylcarbodiimide $(22.6 \mathrm{mg}, 118 \mu \mathrm{mol}), 1$-hydroxybenzotriazole $(18.1$ $\mathrm{mg}, 118 \mu \mathrm{mol})$ and $N, N$-diisopropylethylamine $(54.0 \mu \mathrm{L}, 315 \mu \mathrm{mol})$ in dimethylformamide $(787 \mu \mathrm{L})$, was added a solution of 3-(3-((3-aminopropyl)(methyl)amino)propyl)-8-methoxy-3,5-dihydro-4Hpyrimido[5,4-b]indol-4-one $\mathbf{S} 33(15.0 \mathrm{mg}, 26.2 \mu \mathrm{mol})$ in DMF $(250 \mu \mathrm{L})$. The reaction mixture was stirred at room temperature overnight in the dark, whereupon $2 \mathrm{~mL}$ of methanol/water (1:1 containing $0.1 \%$ TFA) was added. This mixture was purified by preparative HPLC (33-63\% methanol/water in $30 \mathrm{~min}, 0.1 \%$ TFA) and column chromatography (amino silica, $11 \mathrm{~g}, 2-20 \%$ methanol/dichloromethane) to afford 3-(3-(but-3-yn-1-yl)-3H-diazirin-3-yl)-N-(3-((3-(8-methoxy-4oxo-4,5-dihydro-3H-pyrimido[5,4-b]indol-3-yl)propyl)(methyl)amino)propyl)propenamide (11) (2.4 mg, 19\%). ${ }^{1} \mathrm{H}$ NMR (400 MHz, CDCl 3 ) $\delta 9.45(\mathrm{~s}, 1 \mathrm{H}), 8.08(\mathrm{~s}, 1 \mathrm{H}), 7.55(\mathrm{~d}, 1 \mathrm{H}, \mathrm{J}=2.4 \mathrm{~Hz}), 7.48$ $(\mathrm{d}, 1 \mathrm{H}, \mathrm{J}=9.0 \mathrm{~Hz}), 7.21-7.15(\mathrm{~m}, 2 \mathrm{H}), 4.23(\mathrm{t}, 2 \mathrm{H}, \mathrm{J}=7.3 \mathrm{~Hz}), 3.09(\mathrm{~s}, 3 \mathrm{H}), 3.39-3.31(\mathrm{~m}, 2 \mathrm{H})$, 2.48-2.33 (m, 4H), $2.21(\mathrm{~s}, 3 \mathrm{H}), 2.09-1.98(\mathrm{~m}, 6 \mathrm{H}), 1.97-1.94(\mathrm{~m}, 1 \mathrm{H}), 1.94-1.88(\mathrm{~m}, 2 \mathrm{H}), 1.72-$ $1.64(\mathrm{~m}, 4 \mathrm{H}) ;{ }^{13} \mathrm{C}$ NMR $\left(150 \mathrm{MHz}, \mathrm{CDCl}_{3}\right) \delta 171.6,155.0,154.7,142.9,138.6,134.2,122.4,121.9$, 119.5, 113.5, 100.9, 82.7, 69.3, 55.8, 55.0, 44.8, 41.7, 37.2, 32.3, 30.5, 29.7, 28.6, 28.6, 27.3, 26.3, 13.3; HR-MS (ESI): Calcd for $\mathrm{C}_{26} \mathrm{H}_{34} \mathrm{~N}_{7} \mathrm{O}_{3}{ }^{+}, 492.2718$; found, 492.2687. 
NMR Spectra of Compound \$30

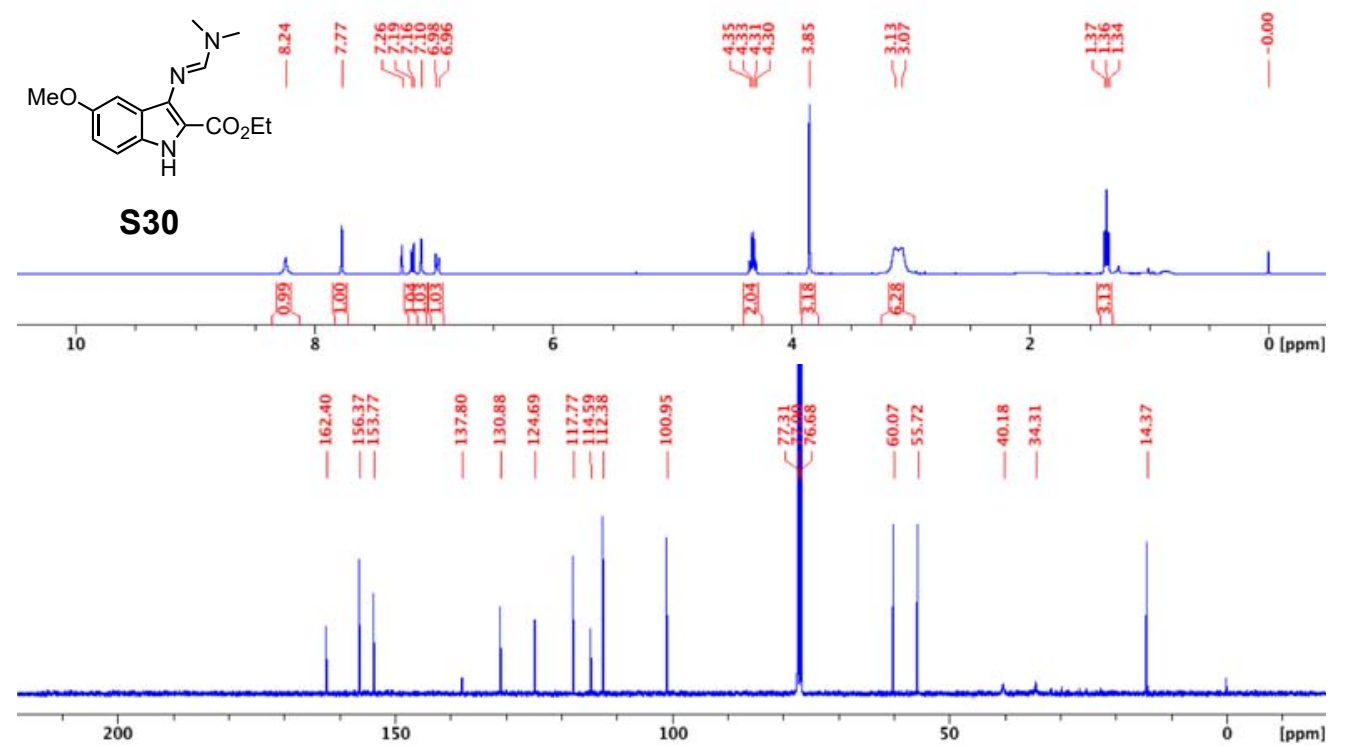

\section{NMR Spectra of Compound 9}

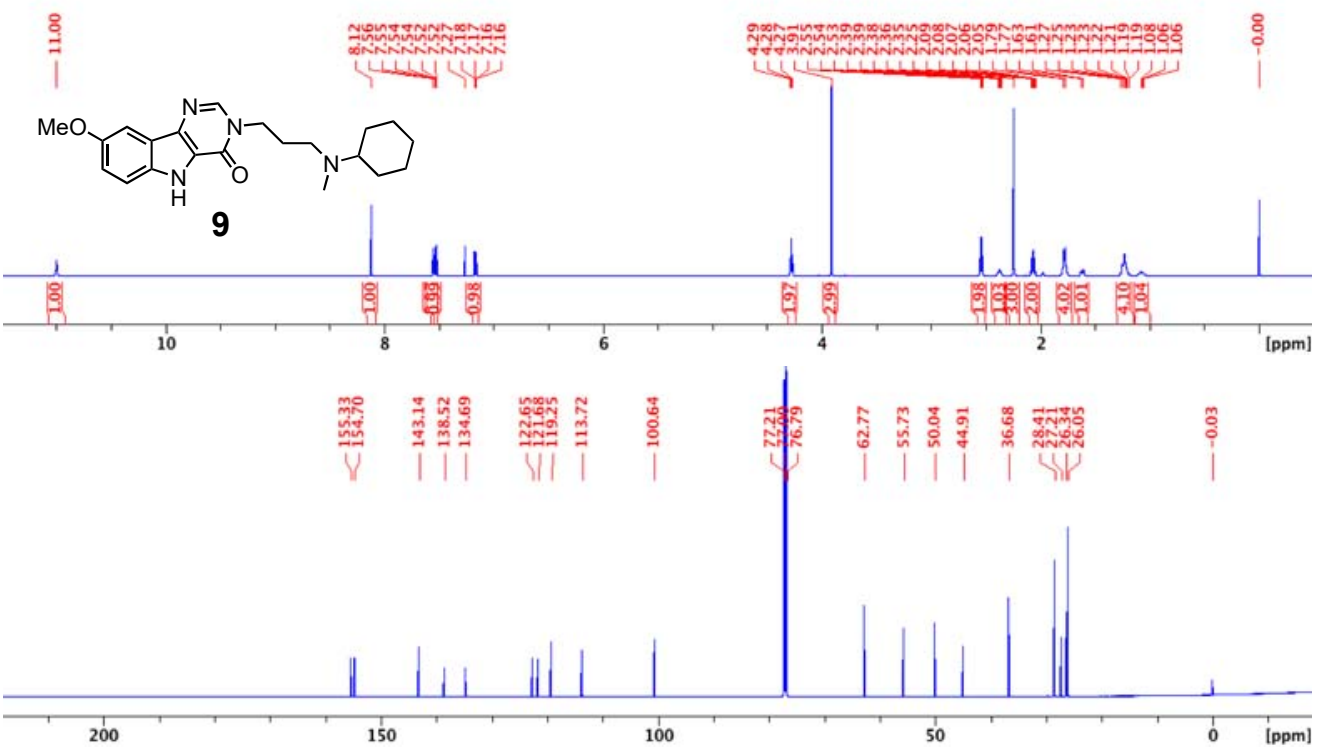


NMR spectra of compound S33

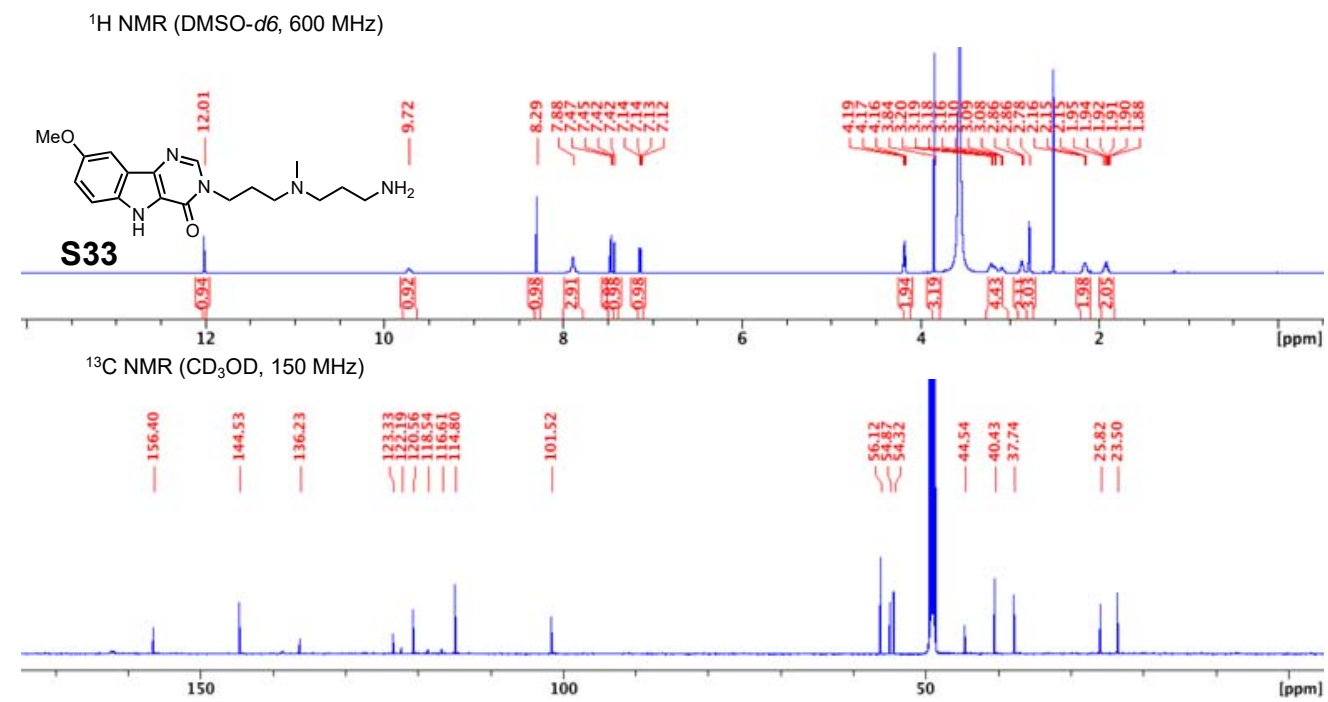

\section{NMR spectra of compound 11}

${ }^{1} \mathrm{H} \mathrm{NMR}\left(\mathrm{CDCl}_{3}, 400 \mathrm{MHz}\right)$

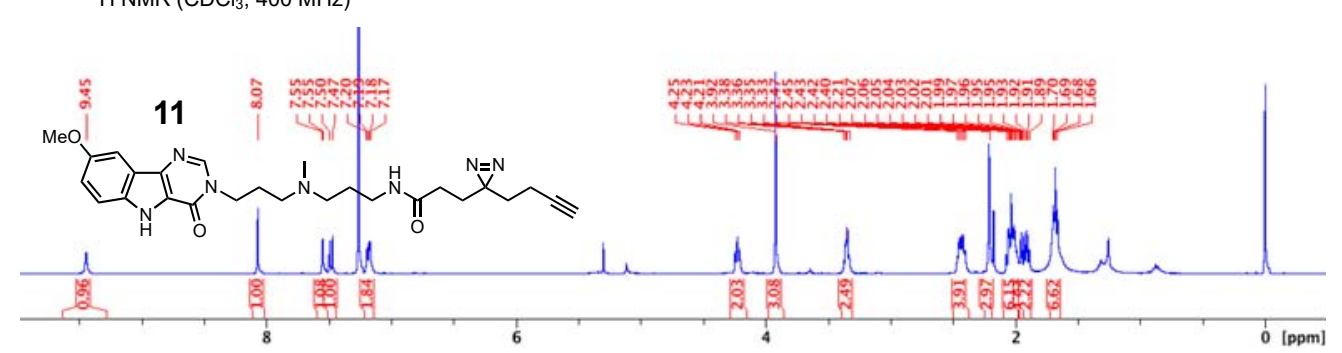

${ }^{13} \mathrm{C} \mathrm{NMR}\left(\mathrm{CDCl}_{3}, 150 \mathrm{MHz}\right)$

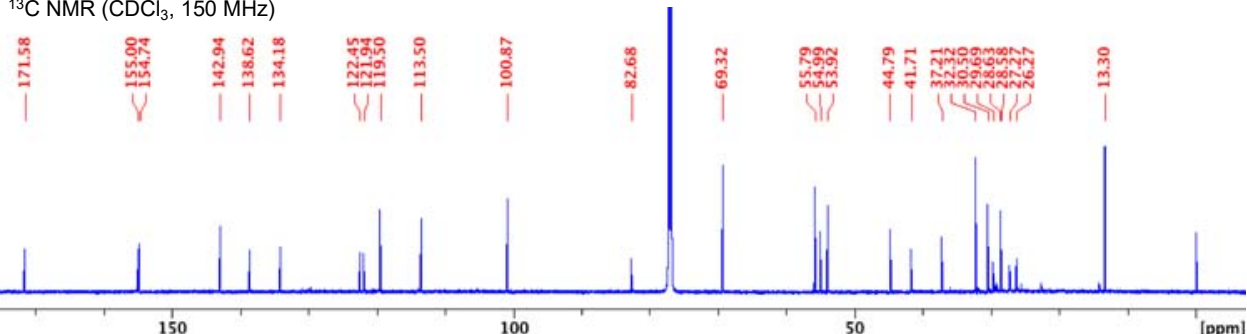




\section{Supplementary Tables}

Table S1: Results of $1 \mathrm{D}{ }^{1} \mathrm{H}$ NMR spectroscopy of the WT and DDPAC stem mimic duplexes with lead compounds.

Table S1A: Results of 1D ${ }^{1} \mathrm{H}$ NMR spectroscopy of the WT stem mimic duplex with lead compounds.

\begin{tabular}{|c|c|c|}
\hline Compound & 1D (iminos) & WaterLOGSY \\
\hline 4 & $\underline{G 3}, \underline{G 4}, \underline{G}, \underline{U 8}, \underline{G 9}, \cup 10, G 17, \underline{U 18}, \underline{G} 20, \underline{G 1}$ & Binds \\
\hline 5 & $\overline{\mathrm{G}}, \overline{\mathrm{G} 4}, \overline{\mathrm{G} 7}, \overline{\mathrm{U} 8}, \overline{\mathrm{G9}}, \underline{\mathrm{U10}}, \underline{\mathrm{G} 17}, \underline{\mathrm{U18}}, \overline{\mathrm{G} 20}, \overline{\mathrm{G} 21}$ & Binds \\
\hline 6 & $\mathrm{G} 3, \overline{\mathrm{G}} 4, \overline{\mathrm{G}}, \mathrm{U}, \overline{\mathrm{G} 9}, \overline{\mathrm{U} 10}, \overline{\mathrm{G} 17}, \overline{\mathrm{U} 18}, \overline{\mathrm{G} 20}, \overline{\mathrm{G} 21}$ & Binds \\
\hline 7 & G3, G4, G7, U8, G9, U10, G17, U18, G20, G21 & Binds \\
\hline 8 & N/A & Insoluble \\
\hline 9 & G3, G4, G7, U8, G9, U10, G17, U18, G20, G21 & Binds \\
\hline
\end{tabular}

Table S1B: Results of $1 \mathrm{D}{ }^{1} \mathrm{H}$ NMR spectroscopy of the DDPAC stem mimic duplex with lead compounds.

\begin{tabular}{|c|c|c|}
\hline Compound & 1D (iminos) & WaterLOGSY \\
\hline 4 & $\underline{G 3}, \underline{G 4}, \underline{G 7}, \underline{U 8}, \underline{G 9}, \cup 10, G 17, \underline{U 14}, \cup 18, \underline{G 20}, \underline{G 1}$ & Binds \\
\hline 5 & $\overrightarrow{\mathrm{G}}, \overrightarrow{\mathrm{G} 4}, \overrightarrow{\mathrm{G} 7}, \overline{\mathrm{U} 8}, \overrightarrow{\mathrm{G} 9}, \mathrm{U10}, \mathrm{U14}, \overrightarrow{\mathrm{G} 17}, \mathrm{U18}, \overline{\mathrm{G} 20}, \overline{\mathrm{G} 21}$ & Is \\
\hline 6 & $\overline{4}, \overline{\mathrm{G} 7}, \mathrm{U8}, \overline{\mathrm{G} 9}, \overline{\mathrm{U} 10}, \overline{\mathrm{U} 14, \mathrm{G} 17}, \overline{\mathrm{U} 18}, \overline{\mathrm{G} 20}, \overline{\mathrm{G} 21}$ & Binds \\
\hline 7 & G3, G4, G7, U8, G9, U10, U14, G17, U18, G20, G21 & Binds \\
\hline 8 & $\mathrm{~N} / \mathrm{A}$ & Insoluble \\
\hline 9 & G3, G4, G7, U8, G9, U10, U14, G17, U18, G20, G21 & Binds \\
\hline
\end{tabular}

Blue: broadens. Red: sharpens. Black: does not sharpen or broaden. Italics: shifts by more than 0.05 ppm or gives separate bound conformation peak. 
Table S2: ${ }^{1} \mathrm{H}$ NMR chemical shifts of the unbound WT stem mimic.

\begin{tabular}{cccccccc}
\hline Residue & $\mathrm{H}^{\prime}$ & $\mathrm{H}^{\prime}$ & $\mathrm{H}^{\prime}$ & $\mathrm{H} 2 / \mathrm{H} 5$ & $\mathrm{H} 6 / \mathrm{H} 8$ & $\mathrm{H} 1 / \mathrm{H} 3$ & $\begin{array}{c}\mathrm{H} 21 / 41 / 61, \mathrm{H} 22 / 42 / 62 \\
\text { amino }\end{array}$ \\
\hline $\mathrm{C} 1$ & 5.610 & 4.471 & 4.561 & 6.091 & 8.207 & $\mathrm{~N} / \mathrm{A}$ & $8.306 / 7.278$ \\
$\mathrm{C} 2$ & 5.676 & 4.688 & 4.486 & 5.673 & 8.05 & $\mathrm{~N} / \mathrm{A}$ & $8.521 / 6.958$ \\
$\mathrm{G} 3$ & 5.807 & 4.642 & 4.573 & $\mathrm{~N} / \mathrm{A}$ & 7.702 & 12.49 & $\mathrm{~N} / \mathrm{A}$ \\
$\mathrm{G} 4$ & 5.803 & 4.621 & 4.517 & $\mathrm{~N} / \mathrm{A}$ & 7.311 & 11.52 & $\mathrm{~N} / \mathrm{A}$ \\
$\mathrm{C} 5$ & 5.654 & 4.614 & 4.222 & 5.394 & 7.546 & $\mathrm{~N} / \mathrm{A}$ & $8.369 / 6.878$ \\
$\mathrm{~A} 6$ & 6.082 & 4.534 & 4.656 & 7.914 & 8.329 & $\mathrm{~N} / \mathrm{A}$ & - \\
$\mathrm{G} 7$ & 5.718 & 4.696 & 4.562 & $\mathrm{~N} / \mathrm{A}$ & 7.79 & 12.79 & - \\
U8 & 5.640 & 4.740 & 4.588 & 5.100 & 7.824 & 13.68 & $\mathrm{~N} / \mathrm{A}$ \\
$\mathrm{G} 9$ & 5.855 & 4.503 & 4.564 & $\mathrm{~N} / \mathrm{A}$ & 7.743 & 12.66 & - \\
U10 & 5.502 & 4.363 & 4.512 & 5.174 & 7.716 & 14.07 & $\mathrm{~N} / \mathrm{A}$ \\
$\mathrm{G} 11$ & 5.908 & 4.085 & 4.344 & $\mathrm{~N} / \mathrm{A}$ & 7.725 & - & - \\
$\mathrm{C} 12$ & 5.542 & 4.530 & 4.628 & 6.041 & 8.166 & $\mathrm{~N} / \mathrm{A}$ & - \\
$\mathrm{A} 13$ & 6.034 & 4.592 & 4.897 & 7.600 & 8.346 & $\mathrm{~N} / \mathrm{A}$ & - \\
$\mathrm{C} 14$ & 5.481 & 4.311 & 4.590 & 5.297 & 7.705 & $\mathrm{~N} / \mathrm{A}$ & $8.323 / 6.93$ \\
$\mathrm{~A} 15$ & 5.973 & 4.535 & 4.436 & 7.485 & 8.079 & $\mathrm{~N} / \mathrm{A}$ & $8.117 / 6.2$ \\
$\mathrm{C} 16$ & 5.484 & 4.320 & 4.435 & 5.340 & 7.407 & $\mathrm{~N} / \mathrm{A}$ & $8.127 / 6.897$ \\
$\mathrm{G} 17$ & 5.711 & 4.615 & 4.507 & $\mathrm{~N} / \mathrm{A}$ & 7.593 & 13.04 & - \\
U18 & 5.426 & 4.110 & 4.564 & 5.516 & 7.909 & 12.23 & $\mathrm{~N} / \mathrm{A}$ \\
$\mathrm{C} 19$ & 5.660 & 4.568 & 4.378 & 5.634 & 8.002 & $\mathrm{~N} / \mathrm{A}$ & $8.388 / 6.756$ \\
$\mathrm{G} 20$ & 5.649 & 4.570 & 4.500 & $\mathrm{~N} / \mathrm{A}$ & 7.493 & 12.71 & - \\
$\mathrm{G} 1$ & 5.866 & 4.064 & - & $\mathrm{N} / \mathrm{A}$ & 7.378 & 13.46 & - \\
\hline
\end{tabular}

Table S3: ${ }^{1} \mathrm{H}$ NMR chemical shifts of the unbound DDPAC stem mimic.

\begin{tabular}{cccccccc}
\hline Residue & $\mathrm{H}^{\prime}$ & $\mathrm{H}^{\prime}$ & $\mathrm{H}^{\prime}$ & $\mathrm{H} 2 / \mathrm{H} 5$ & $\mathrm{H} 6 / \mathrm{H} 8$ & $\mathrm{H} 1 / \mathrm{H} 3$ & $\begin{array}{c}\mathrm{H} 21 / 41 / 61, \mathrm{H} 22 / 42 / 62 \\
\text { amino }\end{array}$ \\
\hline $\mathrm{C} 1$ & 5.586 & 4.420 & 4.527 & 6.059 & 8.181 & $\mathrm{~N} / \mathrm{A}$ & $8.225 / 7.241$ \\
$\mathrm{C} 2$ & 5.630 & 4.614 & - & 5.631 & 8.021 & $\mathrm{~N} / \mathrm{A}$ & $8.462 / 6.953$ \\
$\mathrm{G} 3$ & 5.766 & 4.578 & 4.519 & $\mathrm{~N} / \mathrm{A}$ & 7.667 & 12.47 & - \\
$\mathrm{G} 4$ & 5.749 & 4.558 & 4.472 & $\mathrm{~N} / \mathrm{A}$ & 7.24 & 11.50 & - \\
$\mathrm{C} 5$ & 5.558 & 4.159 & 4.343 & 5.332 & 7.515 & $\mathrm{~N} / \mathrm{A}$ & $8.388 / 6.806$ \\
$\mathrm{~A} 6$ & 5.976 & 4.538 & - & - & 8.194 & $\mathrm{~N} / \mathrm{A}$ & - \\
$\mathrm{G} 7$ & 5.649 & 4.545 & 4.493 & $\mathrm{~N} / \mathrm{A}$ & 7.714 & 12.69 & - \\
U8 & 5.664 & 4.622 & - & 5.125 & 7.768 & 13.80 & $\mathrm{~N} / \mathrm{A}$ \\
$\mathrm{G} 9$ & 5.836 & 4.600 & 4.313 & $\mathrm{~N} / \mathrm{A}$ & 7.691 & 10.90 & - \\
U10 & 5.416 & 4.241 & 4.486 & 5.254 & 7.587 & 13.94 & $\mathrm{~N} / \mathrm{A}$ \\
$\mathrm{G} 11$ & 5.862 & 4.102 & 4.308 & $\mathrm{~N} / \mathrm{A}$ & 7.675 & - & - \\
$\mathrm{C} 12$ & 5.544 & 4.572 & 4.610 & 5.989 & 8.105 & $\mathrm{~N} / \mathrm{A}$ & - \\
$\mathrm{A} 13$ & 6.034 & - & - & 7.560 & 8.157 & $\mathrm{~N} / \mathrm{A}$ & - \\
U14 & 5.327 & 4.08 & 4.581 & 5.501 & 7.653 & 11.52 & $\mathrm{~N} / \mathrm{A}$ \\
$\mathrm{A} 15$ & 5.942 & 4.501 & 4.452 & 7.403 & 8.355 & $\mathrm{~N} / \mathrm{A}$ & - \\
$\mathrm{C} 16$ & 5.551 & 4.246 & 4.391 & 5.356 & 7.435 & $\mathrm{~N} / \mathrm{A}$ & $8.075 / 6.908$ \\
$\mathrm{G} 17$ & 5.659 & 4.589 & 4.473 & $\mathrm{~N} / \mathrm{A}$ & 7.602 & 12.96 & - \\
U18 & 5.376 & 4.515 & - & 5.471 & 7.876 & 12.18 & $\mathrm{~N} / \mathrm{A}$ \\
$\mathrm{C} 19$ & 5.600 & 4.510 & 4.559 & 5.586 & 7.974 & $\mathrm{~N} / \mathrm{A}$ & $8.364 / 6.691$ \\
$\mathrm{G} 20$ & 5.610 & 4.503 & 4.446 & $\mathrm{~N} / \mathrm{A}$ & 7.439 & 12.73 & - \\
$\mathrm{G} 21$ & 5.818 & 4.001 & 4.189 & $\mathrm{~N} / \mathrm{A}$ & 7.305 & 13.48 & - \\
\hline
\end{tabular}


Table S4: ${ }^{1} \mathrm{H}$ NMR chemical shifts of the 4-bound WT stem mimic complex.

Table S4A: ${ }^{1} \mathrm{H}$ NMR chemical shifts of RNA in the 4-bound WT stem mimic complex.

\begin{tabular}{|c|c|c|c|c|c|c|c|}
\hline Residue & $\mathrm{H} 1^{\prime}$ & H2' & H3' & $\mathrm{H} 2 / \mathrm{H} 5$ & H6/H8 & $\mathrm{H} 1 / \mathrm{H} 3$ & $\begin{array}{c}\mathrm{H} 21 / 41 / 61, \mathrm{H} 22 / 42 / 62 \\
\text { amino }\end{array}$ \\
\hline C1 & 5.609 & 4.48 & 4.562 & 6.082 & 8.211 & N/A & $8.349 / 7.316$ \\
\hline $\mathrm{C} 2$ & 5.674 & 4.692 & 4.484 & 5.668 & 8.060 & $\mathrm{~N} / \mathrm{A}$ & $8.557 / 6.991$ \\
\hline G3 & 5.811 & 4.639 & 4.578 & N/A & 7.709 & 12.54 & - \\
\hline G4 & 5.809 & 4.621 & 4.546 & N/A & 7.309 & 11.51 & - \\
\hline $\mathrm{G}^{\dagger}{ }^{\dagger}$ & & & & & & 11.21 & \\
\hline $\mathrm{C} 5$ & 5.670 & 4.534 & 4.246 & 5.404 & 7.559 & $\mathrm{~N} / \mathrm{A}$ & $8.438 / 6.887$ \\
\hline $\mathrm{C5}^{\dagger}$ & 5.539 & - & - & 5.207 & 7.455 & $\mathrm{~N} / \mathrm{A}$ & $8.370 / 6.928$ \\
\hline A6 & 6.104 & 4.560 & - & - & 8.357 & N/A & - \\
\hline $\mathrm{A} 6^{\dagger}$ & 5.935 & - & - & - & - & $\mathrm{N} / \mathrm{A}$ & - \\
\hline G7 & 5.745 & 4.709 & 4.572 & $\mathrm{~N} / \mathrm{A}$ & 7.817 & 11.97 & - \\
\hline $\mathrm{G}^{\dagger}$ & 5.795 & - & - & N/A & 7.368 & 12.85 & - \\
\hline U8 & 5.648 & 4.743 & - & 5.104 & 7.843 & 13.74 & N/A \\
\hline U8 ${ }^{\dagger}$ & - & - & - & 4.997 & - & 13.87 & $\mathrm{~N} / \mathrm{A}$ \\
\hline G9 & 5.856 & 4.505 & 4.594 & N/A & 7.749 & 12.71 & - \\
\hline U10 & 5.503 & 4.357 & 4.527 & 5.179 & 7.725 & 14.10 & $\mathrm{~N} / \mathrm{A}$ \\
\hline G11 & 5.905 & 4.089 & - & $\mathrm{N} / \mathrm{A}$ & 7.727 & - & - \\
\hline C12 & 5.540 & 4.553 & 4.631 & 6.025 & 8.161 & $\mathrm{~N} / \mathrm{A}$ & $8.443 / 7.192$ \\
\hline A13 & 6.029 & 4.588 & 4.896 & 7.580 & 8.342 & $\mathrm{~N} / \mathrm{A}$ & - \\
\hline C14 & 5.486 & 4.310 & 4.587 & 5.290 & 7.715 & $\mathrm{~N} / \mathrm{A}$ & $8.367 / 6.964$ \\
\hline A15 & 5.983 & 4.532 & 4.421 & 7.482 & 8.096 & $\mathrm{~N} / \mathrm{A}$ & - \\
\hline C16 & 5.479 & 4.312 & 4.477 & 5.329 & 7.422 & N/A & $8.165 / 6.945$ \\
\hline C16 ${ }^{\dagger}$ & 5.731 & 4.345 & - & 5.196 & 7.540 & $\mathrm{~N} / \mathrm{A}$ & \\
\hline G17 & 5.720 & 4.614 & 4.538 & $\mathrm{~N} / \mathrm{A}$ & 7.585 & 13.11 & - \\
\hline $\mathrm{G} 17^{\dagger}$ & 5.293 & - & - & N/A & 7.276 & 12.27 & - \\
\hline U18 & 5.434 & 4.112 & 4.557 & 5.524 & 7.921 & 12.25 & $\mathrm{~N} / \mathrm{A}$ \\
\hline U18 & 5.355 & 4.067 & - & 5.228 & 7.739 & 12.00 & $\mathrm{~N} / \mathrm{A}$ \\
\hline C19 & 5.673 & - & 4.382 & 5.643 & 8.021 & N/A & $8.432 / 6.783$ \\
\hline C19' & - & - & - & 5.574 & 7.976 & N/A & - \\
\hline G20 & 5.659 & 4.562 & 4.492 & $N / A$ & 7.498 & - & - \\
\hline G21 & 5.867 & 4.059 & - & N/A & 7.375 & 13.50 & - \\
\hline
\end{tabular}

Table S4B: ${ }^{1} \mathrm{H}$ NMR chemical shifts of 4 in the 4-bound WT stem mimic complex.

\begin{tabular}{c|c}
\hline Hydrogen & Chemical shift \\
\hline $\mathrm{H} 2 / \mathrm{H}^{\prime}$ & $8.044 / 8.050$ \\
$\mathrm{H} 4 / \mathrm{H} 4^{\prime}$ & $8.118 / 8.117$ \\
$\mathrm{H} 5 / \mathrm{H} 5^{\prime}$ & $7.957 / 7.945$ \\
$\mathrm{H} 7 / \mathrm{H}^{\prime}$ ' methyl & $2.097 / 1.984$ \\
\hline
\end{tabular}

Non-exchangeable protons were assigned at $25^{\circ} \mathrm{C}$. Exchangeable protons were assigned at 9 ${ }^{\circ} \mathrm{C}$. 
Table S5: $\mathrm{K}_{d} \mathrm{~S}$ or $\mathrm{IC}_{50} \mathrm{~S}(\mu \mathrm{M})$ determined from in vitro binding assays for compounds binding to RNA constructs.

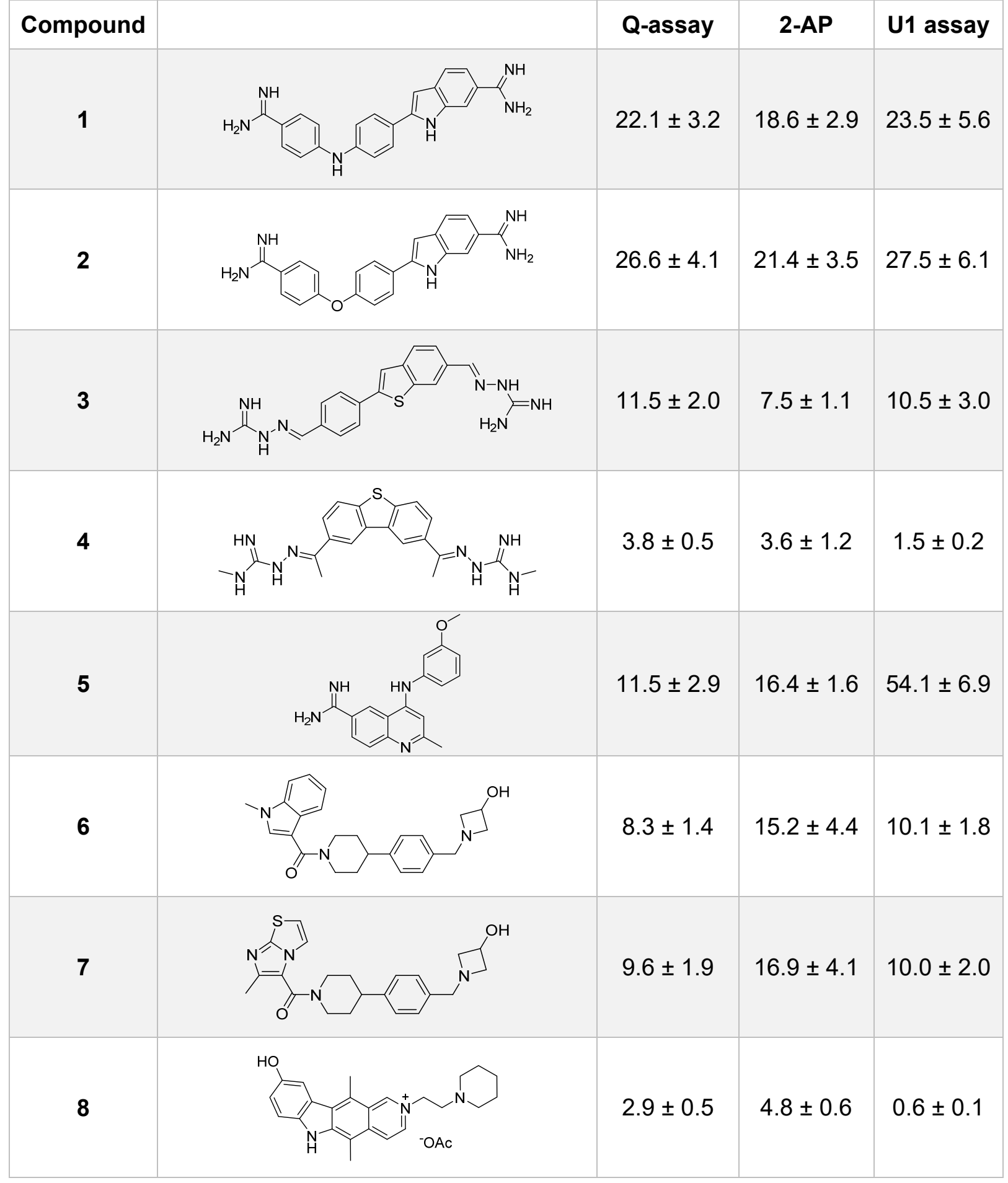




$2.9 \pm 0.9$
$\begin{aligned} & \text { spectral } \\ & \text { overlap }\end{aligned}$


Table S6: $\mathrm{EC}_{50} \mathrm{~S}(\mu \mathrm{M})$ determined from 2-AP competitive assays for compounds 4 to 8 binding to DDPAC RNA constructs.

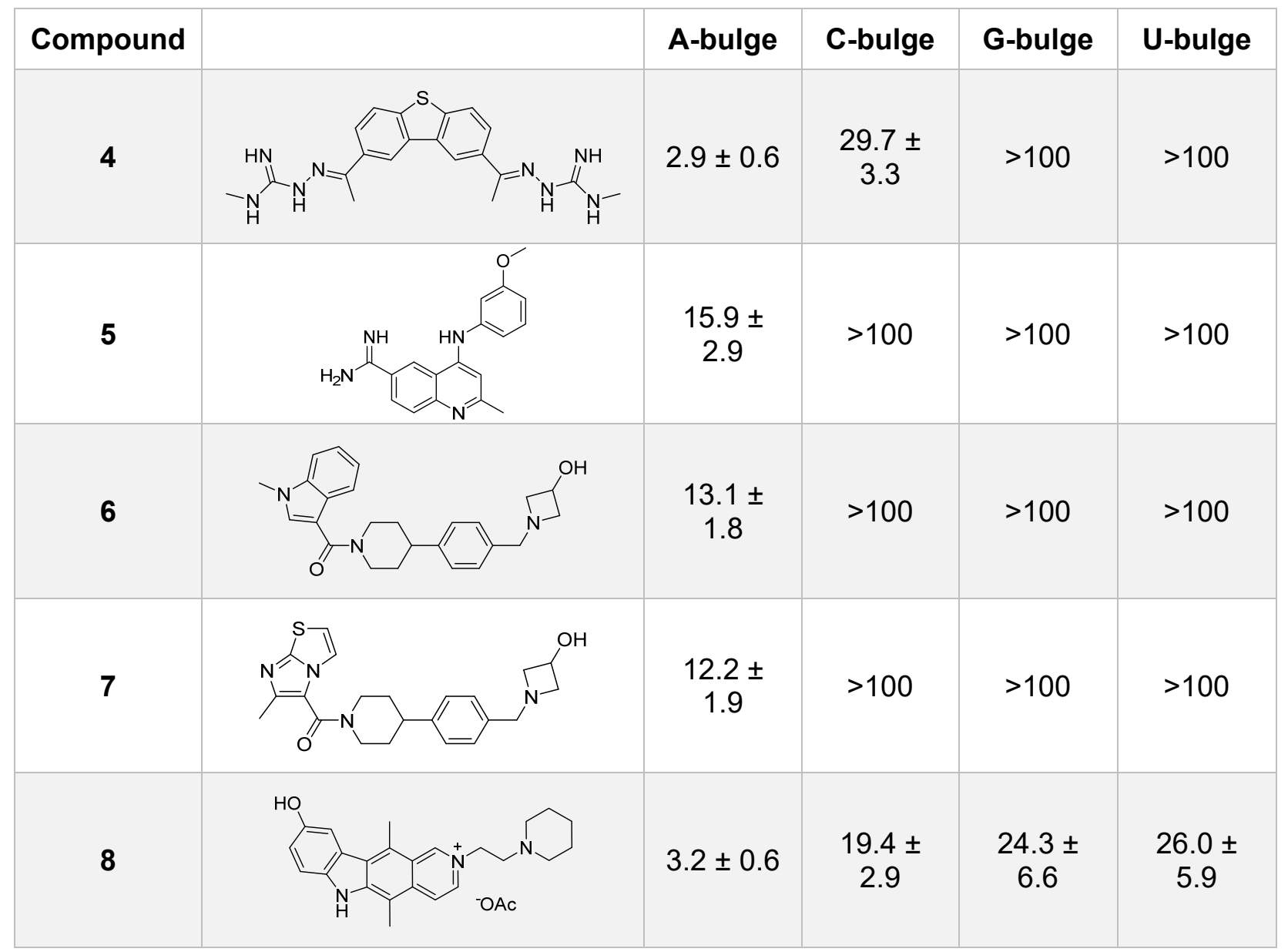

$\mathrm{EC}_{50}$ values $>100$ indicates not saturated until competitor was added to $200 \mu \mathrm{M}$. Compound 9 had spectral overlap with 2-AP. 
Table S7: ${ }^{1} \mathrm{H}$ NMR chemical shifts of the 5-bound WT stem mimic complex.

Table S7A: ${ }^{1} \mathrm{H}$ NMR chemical shifts of RNA in the 5-bound WT stem mimic complex.

\begin{tabular}{ccccccccc}
\hline Residue & $\mathrm{H}^{\prime}$ & $\mathrm{H} 2^{\prime}$ & $\mathrm{H}^{\prime}$ & $\mathrm{H} 4^{\prime}$ & $\mathrm{H} 2 / \mathrm{H} 5$ & $\mathrm{H} 6 / \mathrm{H} 8$ & $\mathrm{H} 1 / \mathrm{H} 3$ & $\begin{array}{c}\mathrm{H} 21 / 41 / 61, \mathrm{H} 22 / 42 / 62 \\
\text { amino }\end{array}$ \\
\hline C1 & 5.614 & 4.466 & 4.561 & 4.404 & 6.080 & 8.195 & $\mathrm{~N} / \mathrm{A}$ & $8.205 / 7.217$ \\
C2 & 5.670 & 4.641 & 4.755 & - & 5.672 & 8.058 & $\mathrm{~N} / \mathrm{A}$ & $8.444 / 6.946$ \\
G3 & 5.812 & 4.631 & 4.553 & 4.567 & - & 7.722 & 12.48 & - \\
G4 & 5.785 & 4.594 & 4.409 & 4.514 & - & 7.272 & 11.52 & - \\
C5 & 5.671 & 4.210 & 4.497 & - & 5.339 & 7.521 & $\mathrm{~N} / \mathrm{A}$ & $8.359 / 6.798$ \\
A6 & 6.071 & 4.526 & 4.874 & 4.246 & - & 8.330 & $\mathrm{~N} / \mathrm{A}$ & - \\
G7 & 5.700 & 4.559 & 4.420 & - & - & 7.808 & 12.75 & - \\
U8 & 5.649 & 4.564 & 4.603 & - & 5.112 & 7.843 & 13.70 & $\mathrm{~N} / \mathrm{A}$ \\
G9 & 5.859 & 4.495 & 4.605 & 4.544 & - & 7.763 & 12.57 & - \\
U10 & 5.514 & 4.335 & 4.524 & 4.427 & 5.186 & 7.714 & 14.04 & $\mathrm{~N} / \mathrm{A}$ \\
G11 & 5.890 & 4.074 & 4.331 & 4.254 & - & 7.724 & - & - \\
C12 & 5.551 & 4.519 & 4.625 & 4.392 & 5.994 & 8.12 & $\mathrm{~N} / \mathrm{A}$ & - \\
A13 & 6.017 & 4.575 & 4.879 & - & 7.594 & 8.337 & $\mathrm{~N} / \mathrm{A}$ & - \\
C14 & 5.480 & 4.311 & 4.577 & 4.465 & 5.287 & 7.697 & $\mathrm{~N} / \mathrm{A}$ & $8.263 / 6.861$ \\
A15 & 5.971 & 4.517 & 4.740 & 4.191 & 7.481 & 8.074 & $\mathrm{~N} / \mathrm{A}$ & - \\
C16 & 5.497 & 4.326 & 4.454 & 4.431 & 5.304 & 7.411 & $\mathrm{~N} / \mathrm{A}$ & $8.059 / 6.846$ \\
G17 & 5.683 & 4.626 & 4.506 & 4.436 & - & 7.617 & 13.00 & - \\
U18 & 5.445 & 4.113 & 4.572 & 4.408 & 5.506 & 7.899 & 12.15 & $\mathrm{~N} / \mathrm{A}$ \\
C19 & 5.654 & 4.55 & 4.559 & - & 5.629 & 8.015 & $\mathrm{~N} / \mathrm{A}$ & $8.360 / 6.689$ \\
G20 & 5.661 & 4.542 & 4.499 & 4.446 & - & 7.492 & 12.71 & - \\
G21 & 5.854 & 4.041 & 4.240 & - & - & 7.373 & 13.37 & - \\
\hline
\end{tabular}

Table S7B: ${ }^{1} \mathrm{H}$ NMR chemical shifts of 5 in the 5 -bound WT stem mimic complex.

\begin{tabular}{c|c}
\hline Hydrogen & Chemical shift \\
\hline $\mathrm{H} 1$ & 8.726 \\
$\mathrm{H} 2$ & 8.055 \\
$\mathrm{H} 3$ & 7.761 \\
$\mathrm{H} 4$ & 6.752 \\
$\mathrm{H} 5 / \mathrm{H} 6$ & 6.919 \\
$\mathrm{H} 7$ & 7.403 \\
$\mathrm{H} 8$ & 6.919 \\
$\mathrm{H} 15 / \mathrm{H} 16 / \mathrm{H} 17$ methyl & 2.483 \\
$\mathrm{H} 18 / \mathrm{H} 19 / \mathrm{H} 20$ methyl & 3.830 \\
\hline
\end{tabular}

Non-exchangeable protons were assigned at $35^{\circ} \mathrm{C}$. Exchangeable protons were assigned at 5 ${ }^{\circ} \mathrm{C}$. 
Table S8: ${ }^{1} \mathrm{H}$ NMR chemical shifts of the 9 -bound WT stem mimic complex.

Table S8A: ${ }^{1} \mathrm{H}$ NMR chemical shifts of RNA in the 9-bound WT stem mimic complex.

\begin{tabular}{cccccccc}
\hline Residue & $\mathrm{H}^{\prime}$ & $\mathrm{H} 2^{\prime}$ & $\mathrm{H} 3^{\prime}$ & $\mathrm{H} 2 / \mathrm{H} 5$ & $\mathrm{H} 6 / \mathrm{H} 8$ & $\mathrm{H} 1 / \mathrm{H} 3$ & $\begin{array}{c}\mathrm{H} 21 / 41 / 61, \mathrm{H} 22 / 42 / 62 \\
\text { amino }\end{array}$ \\
\hline C1 & 5.522 & 4.42 & 4.483 & 5.991 & 8.130 & $\mathrm{~N} / \mathrm{A}$ & $8.200 / 7.166$ \\
C2 & 5.587 & 4.597 & 4.685 & 5.585 & 7.971 & $\mathrm{~N} / \mathrm{A}$ & $8.411 / 6.915$ \\
G3 & 5.742 & 4.570 & 4.506 & $\mathrm{~N} / \mathrm{A}$ & 7.645 & 12.49 & - \\
G4 & 5.732 & 4.542 & 4.377 & $\mathrm{~N} / \mathrm{A}$ & 7.221 & 11.50 & - \\
C5 & 5.597 & 4.152 & 4.449 & 5.308 & 7.466 & $\mathrm{~N} / \mathrm{A}$ & $8.363 / 6.732$ \\
A6 & 6.020 & 4.489 & 4.812 & - & 8.277 & $\mathrm{~N} / \mathrm{A}$ & - \\
G7 & 5.632 & 4.638 & 4.510 & $\mathrm{~N} / \mathrm{A}$ & 7.722 & 12.72 & - \\
U8 & 5.591 & 4.687 & 4.547 & 5.029 & 7.767 & 13.68 & $\mathrm{~N} / \mathrm{A}$ \\
G9 & 5.797 & 4.440 & 4.541 & $\mathrm{~N} / \mathrm{A}$ & 7.690 & 12.57 & - \\
U10 & 5.443 & 4.290 & 4.481 & 5.114 & 7.661 & 14.00 & $\mathrm{~N} / \mathrm{A}$ \\
G11 & 5.846 & 4.095 & 4.322 & $\mathrm{~N} / \mathrm{A}$ & 7.671 & - & - \\
C12 & 5.431 & 4.473 & 4.546 & 5.917 & 8.070 & $\mathrm{~N} / \mathrm{A}$ & - \\
A13 & 5.932 & 4.497 & 4.814 & 7.470 & 8.238 & $\mathrm{~N} / \mathrm{A}$ & - \\
C14 & 5.407 & 4.239 & 4.406 & 5.210 & 7.630 & $\mathrm{~N} / \mathrm{A}$ & $8.245 / 6.827$ \\
A15 & 5.913 & 4.455 & 4.692 & 7.415 & 8.020 & $\mathrm{~N} / \mathrm{A}$ & - \\
C16 & 5.469 & 4.305 & 4.370 & 5.270 & 7.368 & $\mathrm{~N} / \mathrm{A}$ & $8.053 / 6.818$ \\
G17 & 5.619 & 4.565 & - & $\mathrm{N} / \mathrm{A}$ & 7.543 & 13.00 & - \\
U18 & 5.375 & 4.054 & 4.498 & 5.431 & 7.845 & 12.17 & $\mathrm{~N} / \mathrm{A}$ \\
C19 & 5.597 & 4.507 & - & 5.576 & 7.954 & $\mathrm{~N} / \mathrm{A}$ & $8.339 / 6.662$ \\
G20 & 5.594 & 4.494 & 4.439 & $\mathrm{~N} / \mathrm{A}$ & 7.432 & 12.68 & - \\
G21 & 5.797 & 4.038 & 4.208 & $\mathrm{~N} / \mathrm{A}$ & 7.310 & 13.17 & - \\
\hline
\end{tabular}

Table S8B: ${ }^{1} \mathrm{H}$ NMR chemical shifts of 9 in the 9-bound WT stem mimic complex.

\begin{tabular}{c|c}
\hline Hydrogen & Chemical shift \\
\hline $\mathrm{H} 1$ & 6.787 \\
$\mathrm{H} 2$ & 7.190 \\
$\mathrm{H} 3$ & 7.068 \\
$\mathrm{H} 8$ & 7.974 \\
$\mathrm{H} 4 / \mathrm{H} 5 / \mathrm{H} 6$ methyl & 3.666 \\
$\mathrm{H} 16 / \mathrm{H} 17 / \mathrm{H} 18$ methyl & 2.144 \\
\hline
\end{tabular}

Non-exchangeable protons were assigned at $25{ }^{\circ} \mathrm{C}$. Exchangeable protons were assigned at 5 ${ }^{\circ} \mathrm{C}$. 
Table S9: NOE restraints used for modeling of unbound stem mimic duplex.

\begin{tabular}{|c|c|c|c|c|c|c|c|}
\hline 1 & C & $\mathrm{H} 1^{\prime}$ & 1 & C & $\mathrm{H} 2^{\prime}$ & 2.32 & 3.32 \\
\hline 1 & C & $\mathrm{H} 6$ & 1 & C & $\mathrm{H} 1^{\prime}$ & 2.67 & 3.67 \\
\hline 1 & C & H6 & 1 & C & $\mathrm{H} 2^{\prime}$ & 2.91 & 3.91 \\
\hline 1 & C & $\mathrm{H} 6$ & 1 & C & $\mathrm{H}^{\prime}{ }^{\prime}$ & 2.71 & 4.21 \\
\hline 1 & C & $\mathrm{H} 6$ & 1 & C & H5 & 2.40 & 2.60 \\
\hline 1 & C & $\mathrm{H} 6$ & 2 & C & H5 & 3.96 & 5.46 \\
\hline 2 & C & $\mathrm{H} 6$ & 1 & C & $\mathrm{H} 1^{\prime}$ & 3.46 & 4.96 \\
\hline 2 & C & $\mathrm{H} 6$ & 1 & $C$ & $\mathrm{H} 2^{\prime}$ & 2.02 & 3.02 \\
\hline 2 & C & $\mathrm{H} 1^{\prime}$ & 2 & C & $\mathrm{H} 2^{\prime}$ & 2.48 & 3.48 \\
\hline 2 & C & $\mathrm{H} 6$ & 2 & C & H5 & 2.40 & 2.60 \\
\hline 3 & G & H8 & 2 & C & $\mathrm{H} 1^{\prime}$ & 3.79 & 5.28 \\
\hline 3 & G & H8 & 2 & C & $\mathrm{H} 2^{\prime}$ & 2.50 & 3.50 \\
\hline 3 & G & $\mathrm{H} 1^{\prime}$ & 3 & G & $\mathrm{H} 2^{\prime}$ & 2.31 & 3.31 \\
\hline 3 & G & H8 & 3 & G & $\mathrm{H} 1^{\prime}$ & 2.79 & 3.79 \\
\hline 4 & G & H8 & 3 & G & $\mathrm{H} 2^{\prime}$ & 2.44 & 3.44 \\
\hline 4 & G & H8 & 3 & G & H3 ' & 3.30 & 4.80 \\
\hline 4 & G & $\mathrm{H} 1^{\prime}$ & 4 & G & $\mathrm{H} 2^{\prime}$ & 2.44 & 3.44 \\
\hline 4 & G & $\mathrm{H} 1^{\prime}$ & 4 & G & $\mathrm{H}^{\prime}{ }^{\prime}$ & 3.10 & 4.60 \\
\hline 4 & G & H8 & 4 & G & $\mathrm{H} 1^{\prime}$ & 3.01 & 4.01 \\
\hline 4 & G & H8 & 5 & C & H5 & 3.41 & 4.91 \\
\hline 5 & C & $\mathrm{H} 6$ & 4 & G & $\mathrm{H} 1^{\prime}$ & 4.40 & 5.90 \\
\hline 5 & C & $\mathrm{H} 6$ & 4 & G & $\mathrm{H} 2^{\prime}$ & 1.77 & 2.77 \\
\hline 5 & C & $\mathrm{H} 6$ & 4 & G & H3 ' & 2.77 & 4.27 \\
\hline 5 & C & $\mathrm{H} 6$ & 4 & G & H8 & 2.97 & 4.47 \\
\hline 5 & C & $\mathrm{H} 1^{\prime}$ & 5 & C & $\mathrm{H} 2^{\prime}$ & 2.19 & 3.19 \\
\hline 5 & C & $\mathrm{H} 1^{\prime}$ & 5 & C & H3 ' & 2.73 & 4.23 \\
\hline 5 & C & $\mathrm{H} 6$ & 5 & C & $\mathrm{H} 1^{\prime}$ & 2.81 & 3.81 \\
\hline 5 & C & $\mathrm{H} 6$ & 5 & C & H3 ' & 2.79 & 4.29 \\
\hline 5 & C & $\mathrm{H} 6$ & 5 & C & H5 & 2.40 & 2.60 \\
\hline 6 & A & H8 & 5 & C & $\mathrm{H} 1^{\prime}$ & 4.00 & 5.50 \\
\hline 6 & A & H8 & 5 & C & $\mathrm{H} 2^{\prime}$ & 2.23 & 3.23 \\
\hline 6 & A & H8 & 5 & C & $\mathrm{H}^{\prime}{ }^{\prime}$ & 2.71 & 4.21 \\
\hline 6 & A & $\mathrm{H} 1^{\prime}$ & 6 & A & $\mathrm{H} 2^{\prime}$ & 2.67 & 3.67 \\
\hline 6 & A & $\mathrm{H} 1^{\prime}$ & 6 & A & $\mathrm{H}^{\prime}{ }^{\prime}$ & 3.24 & 4.74 \\
\hline 6 & A & $\mathrm{H} 2$ & 6 & A & $\mathrm{H} 1^{\prime}$ & 3.95 & 5.45 \\
\hline 6 & A & H8 & 6 & A & $\mathrm{H} 1^{\prime}$ & 2.93 & 3.93 \\
\hline 6 & A & H8 & 6 & A & $\mathrm{H} 2^{\prime}$ & 2.76 & 3.76 \\
\hline 7 & G & H8 & 6 & A & $\mathrm{H} 1^{\prime}$ & 3.98 & $5.4 \varepsilon$ \\
\hline 7 & G & $\mathrm{H} 1^{\prime}$ & 7 & G & $\mathrm{H} 2^{\prime}$ & 2.46 & 3.46 \\
\hline 7 & G & $\mathrm{H} 1^{\prime}$ & 7 & G & $\mathrm{H}^{\prime}{ }^{\prime}$ & 3.53 & 5.03 \\
\hline 7 & G & H8 & 7 & G & $\mathrm{H} 1^{\prime}$ & 2.94 & 3.94 \\
\hline 8 & U & $\mathrm{H} 6$ & 7 & G & $\mathrm{H} 1^{\prime}$ & 3.33 & 4.83 \\
\hline 8 & U & $\mathrm{H} 6$ & 7 & G & $\mathrm{H} 2^{\prime}$ & 2.22 & 3.22 \\
\hline 8 & U & $\mathrm{H} 6$ & 7 & G & H3 ' & 2.52 & 4.02 \\
\hline 8 & U & $\mathrm{H} 6$ & 8 & U & $\mathrm{H} 1^{\prime}$ & 3.04 & 4.54 \\
\hline 8 & U & $\mathrm{H} 6$ & 8 & $U$ & $\mathrm{H} 2^{\prime}$ & 3.17 & 4.17 \\
\hline 8 & U & $\mathrm{H} 6$ & 8 & U & H5 & 2.40 & 2.60 \\
\hline 9 & G & H8 & 8 & $U$ & $\mathrm{H} 1^{\prime}$ & 3.62 & 5.12 \\
\hline 9 & G & H8 & 8 & U & $\mathrm{H} 2^{\prime}$ & 2.60 & 3.60 \\
\hline
\end{tabular}




\begin{tabular}{|c|c|c|c|c|c|c|c|}
\hline 9 & $\mathrm{G}$ & $\mathrm{H} 1^{\prime}$ & 9 & G & $\mathrm{H} 2^{\prime}$ & 2.34 & 3.34 \\
\hline 9 & $\mathrm{G}$ & $\mathrm{H} 1^{\prime}$ & 9 & G & $\mathrm{H} 3^{\prime}$ & 3.59 & 5.09 \\
\hline 9 & G & H8 & 9 & G & $\mathrm{H} 1^{\prime}$ & 3.54 & 4.54 \\
\hline 10 & $U$ & H6 & 9 & G & $\mathrm{H} 1^{\prime}$ & 3.64 & 5.14 \\
\hline 10 & $\mathrm{U}$ & $\mathrm{H} 1^{\prime}$ & 10 & U & $\mathrm{H} 2^{\prime}$ & 2.27 & 3.27 \\
\hline 10 & $\mathrm{U}$ & $\mathrm{H} 1^{\prime}$ & 10 & U & $\mathrm{H} 3^{\prime}$ & 3.07 & 4.57 \\
\hline 10 & U & $\mathrm{H} 6$ & 10 & U & $\mathrm{H} 1^{\prime}$ & 2.90 & 3.90 \\
\hline 10 & $\mathrm{U}$ & $\mathrm{H} 6$ & 10 & U & H5 & 2.40 & 2.60 \\
\hline 11 & $G$ & H8 & 10 & U & $\mathrm{H} 1^{\prime}$ & 3.24 & 4.74 \\
\hline 11 & G & H8 & 10 & U & $\mathrm{H} 2^{\prime}$ & 1.91 & 2.91 \\
\hline 11 & G & $\mathrm{H} 1^{\prime}$ & 11 & G & $\mathrm{H} 2^{\prime}$ & 2.42 & 3.42 \\
\hline 11 & $\mathrm{G}$ & $\mathrm{H} 1^{\prime}$ & 11 & G & H3 ${ }^{\prime}$ & 3.43 & 4.93 \\
\hline 11 & $\mathrm{G}$ & H8 & 11 & G & $\mathrm{H} 1^{\prime}$ & 2.94 & 3.94 \\
\hline 11 & $\mathrm{G}$ & H8 & 11 & G & $\mathrm{H} 2^{\prime}$ & 2.86 & 3.86 \\
\hline 11 & $\mathrm{G}$ & H8 & 11 & G & $\mathrm{H} 3^{\prime}$ & 3.40 & 4.90 \\
\hline 12 & C & $\mathrm{H} 1^{\prime}$ & 12 & C & $\mathrm{H} 2^{\prime}$ & 2.66 & 3.66 \\
\hline 12 & $C$ & H6 & 12 & C & $\mathrm{H} 1^{\prime}$ & 2.97 & 3.97 \\
\hline 12 & $C$ & H6 & 12 & C & $\mathrm{H} 2^{\prime}$ & 2.84 & 3.84 \\
\hline 12 & C & $\mathrm{H} 6$ & 12 & C & H3 ' & 2.65 & 4.15 \\
\hline 12 & $C$ & H6 & 12 & C & H5 & 2.40 & 2.60 \\
\hline 13 & $A$ & $\mathrm{H} 2$ & 11 & G & $\mathrm{H} 1^{\prime}$ & 2.99 & 3.99 \\
\hline 13 & $A$ & H8 & 12 & $C$ & $\mathrm{H} 1^{\prime}$ & 4.23 & 5.73 \\
\hline 13 & $A$ & H8 & 12 & C & $\mathrm{H} 2^{\prime}$ & 2.17 & 3.17 \\
\hline 13 & $A$ & H8 & 12 & C & H3 ${ }^{\prime}$ & 2.83 & 4.33 \\
\hline 13 & $A$ & $\mathrm{H} 1^{\prime}$ & 13 & A & $\mathrm{H} 2^{\prime}$ & 2.42 & 3.42 \\
\hline 13 & $A$ & $\mathrm{H} 1^{\prime}$ & 13 & $A$ & H3 ${ }^{\prime}$ & 3.44 & 4.94 \\
\hline 13 & A & $\mathrm{H} 2$ & 13 & A & $\mathrm{H} 1^{\prime}$ & 3.75 & 4.75 \\
\hline 13 & $A$ & H8 & 13 & $A$ & $\mathrm{H} 1^{\prime}$ & 3.27 & 4.27 \\
\hline 13 & $A$ & H8 & 13 & $A$ & H3 ' & 3.00 & 4.50 \\
\hline 13 & A & H8 & 14 & C & H5 & 3.61 & 5.11 \\
\hline 14 & $C$ & H5 & 13 & $A$ & $\mathrm{H} 2^{\prime}$ & 3.71 & 5.21 \\
\hline 14 & $C$ & H5 & 13 & A & H3 ' & 2.64 & 4.14 \\
\hline 14 & $C$ & $\mathrm{H} 6$ & 13 & $A$ & $\mathrm{H} 1^{\prime}$ & 3.58 & 5.08 \\
\hline 14 & $C$ & H6 & 13 & $A$ & $\mathrm{H} 2^{\prime}$ & 1.88 & 2.88 \\
\hline 14 & $C$ & H6 & 13 & $A$ & $\mathrm{H} 3^{\prime}$ & 3.06 & 4.56 \\
\hline 14 & $C$ & $\mathrm{H} 1^{\prime}$ & 14 & $C$ & $\mathrm{H} 2^{\prime}$ & 2.16 & 3.16 \\
\hline 14 & $C$ & $\mathrm{H} 1^{\prime}$ & 14 & C & $\mathrm{H} 3^{\prime}$ & 3.65 & 5.15 \\
\hline 14 & $C$ & $\mathrm{H} 6$ & 14 & $C$ & $\mathrm{H} 1^{\prime}$ & 2.84 & 3.84 \\
\hline 14 & C & H6 & 14 & C & $\mathrm{H} 2^{\prime}$ & 3.04 & 4.04 \\
\hline 14 & C & $\mathrm{H} 6$ & 14 & C & H5 & 2.40 & 2.60 \\
\hline 15 & $A$ & $\mathrm{H} 2$ & 9 & G & $\mathrm{H} 1^{\prime}$ & 3.03 & 4.03 \\
\hline 15 & $A$ & H8 & 14 & C & $\mathrm{H} 1^{\prime}$ & 3.29 & 4.79 \\
\hline 15 & $A$ & H8 & 14 & $C$ & $\mathrm{H} 2^{\prime}$ & 2.07 & 3.07 \\
\hline 15 & $A$ & H8 & 14 & C & $\mathrm{H} 3^{\prime}$ & 3.11 & 4.61 \\
\hline 15 & A & H8 & 14 & C & H5 & 4.18 & 5.68 \\
\hline 15 & $A$ & $\mathrm{H} 1^{\prime}$ & 15 & $A$ & $\mathrm{H} 2^{\prime}$ & 2.51 & 3.51 \\
\hline 15 & $A$ & $\mathrm{H} 2$ & 15 & $A$ & $\mathrm{H} 1^{\prime}$ & 4.00 & 6.00 \\
\hline 15 & $A$ & H8 & 15 & $A$ & $\mathrm{H} 1^{\prime}$ & 3.43 & 4.43 \\
\hline 15 & $A$ & $\mathrm{H} 2$ & 16 & C & $\mathrm{H} 1^{\prime}$ & 3.30 & 4.30 \\
\hline 15 & $A$ & H8 & 16 & $C$ & H5 & 4.15 & 5.65 \\
\hline 16 & $C$ & H6 & 15 & $A$ & $\mathrm{H} 1^{\prime}$ & 3.42 & 4.92 \\
\hline 16 & $C$ & $\mathrm{H} 6$ & 15 & $A$ & $\mathrm{H} 2^{\prime}$ & 2.02 & 3.02 \\
\hline
\end{tabular}

Supporting Information Page 69 


\begin{tabular}{|c|c|c|c|c|c|c|c|}
\hline 16 & $C$ & $\mathrm{H} 6$ & 15 & A & H3 ${ }^{\prime}$ & 2.30 & 3.80 \\
\hline 16 & $C$ & $\mathrm{H} 1^{\prime}$ & 16 & C & $\mathrm{H} 2^{\prime}$ & 2.52 & 3.52 \\
\hline 16 & C & $\mathrm{H} 1^{\prime}$ & 16 & $C$ & $\mathrm{H} 3^{\prime}$ & 2.28 & 3.78 \\
\hline 16 & C & $\mathrm{H} 6$ & 16 & C & $\mathrm{H} 1^{\prime}$ & 2.97 & 3.97 \\
\hline 16 & C & $\mathrm{H} 6$ & 16 & C & H5 & 2.40 & 2.60 \\
\hline 17 & $\mathrm{G}$ & H8 & 16 & $C$ & $\mathrm{H} 1^{\prime}$ & 3.10 & 4.60 \\
\hline 17 & $\mathrm{G}$ & H8 & 16 & C & $\mathrm{H} 2^{\prime}$ & 2.07 & 3.07 \\
\hline 17 & $\mathrm{G}$ & H8 & 16 & $C$ & $\mathrm{H} 3^{\prime}$ & 2.88 & 4.38 \\
\hline 17 & $\mathrm{G}$ & $\mathrm{H} 1^{\prime}$ & 17 & G & $\mathrm{H} 2^{\prime}$ & 2.34 & 3.34 \\
\hline 17 & $\mathrm{G}$ & H8 & 17 & G & $\mathrm{H} 1^{\prime}$ & 3.16 & 4.16 \\
\hline 17 & $G$ & H8 & 17 & G & H3 ${ }^{\prime}$ & 2.72 & 4.22 \\
\hline 18 & $\mathrm{U}$ & H5 & 17 & G & $\mathrm{H} 2^{\prime}$ & 4.27 & 5.77 \\
\hline 18 & U & $\mathrm{H} 6$ & 17 & G & $\mathrm{H} 1^{\prime}$ & 3.87 & 5.37 \\
\hline 18 & $\mathrm{U}$ & $\mathrm{H} 6$ & 17 & G & $\mathrm{H} 2^{\prime}$ & 2.14 & 3.14 \\
\hline 18 & $\mathrm{U}$ & $\mathrm{H} 6$ & 17 & G & $\mathrm{H} 3^{\prime}$ & 2.72 & 4.22 \\
\hline 18 & $U$ & $\mathrm{H} 1^{\prime}$ & 18 & U & $\mathrm{H} 2^{\prime}$ & 2.32 & 3.32 \\
\hline 18 & $\mathrm{U}$ & $\mathrm{H} 6$ & 18 & U & $\mathrm{H} 1^{\prime}$ & 3.00 & 4.00 \\
\hline 18 & $\mathrm{U}$ & $\mathrm{H} 6$ & 18 & U & $\mathrm{H} 2^{\prime}$ & 2.76 & 3.76 \\
\hline 18 & $\mathrm{U}$ & $\mathrm{H} 6$ & 18 & U & H3 ${ }^{\prime}$ & 2.58 & 4.08 \\
\hline 18 & U & $\mathrm{H} 6$ & 18 & U & H5 & 2.40 & 2.60 \\
\hline 19 & C & $\mathrm{H} 6$ & 18 & U & $\mathrm{H} 1^{\prime}$ & 3.89 & 5.39 \\
\hline 19 & C & $\mathrm{H} 6$ & 18 & U & $\mathrm{H} 2^{\prime}$ & 1.90 & 2.90 \\
\hline 19 & C & $\mathrm{H} 6$ & 18 & U & H5 & 2.62 & 5.12 \\
\hline 19 & $C$ & $\mathrm{H} 1^{\prime}$ & 19 & C & $\mathrm{H} 2^{\prime}$ & 2.64 & 3.64 \\
\hline 19 & $\mathrm{C}$ & $\mathrm{H}^{\prime}{ }^{\prime}$ & 19 & C & $\mathrm{H}^{\prime}$ & 2.74 & 4.24 \\
\hline 19 & $C$ & $\mathrm{H} 6$ & 19 & C & $\mathrm{H} 1^{\prime}$ & 3.07 & 4.07 \\
\hline 19 & $C$ & $\mathrm{H} 6$ & 19 & C & H5 & 2.40 & 2.60 \\
\hline 19 & $C$ & $\mathrm{H} 6$ & 20 & G & H8 & 3.03 & 4.53 \\
\hline 20 & G & H8 & 19 & C & $\mathrm{H} 1^{\prime}$ & 3.49 & 4.99 \\
\hline 20 & $G$ & H8 & 19 & C & $\mathrm{H} 2^{\prime}$ & 1.90 & 2.90 \\
\hline 20 & G & H8 & 19 & C & H3 ' & 3.63 & 5.13 \\
\hline 20 & G & $\mathrm{H} 1^{\prime}$ & 20 & G & $\mathrm{H} 2^{\prime}$ & 2.10 & 3.10 \\
\hline 20 & $\mathrm{G}$ & H8 & 20 & G & $\mathrm{H} 1^{\prime}$ & 3.01 & 4.01 \\
\hline 21 & $\mathrm{G}$ & H8 & 20 & G & $\mathrm{H} 1^{\prime}$ & $4.0 \odot$ & 5.50 \\
\hline 21 & $G$ & H8 & 20 & G & $\mathrm{H} 2^{\prime}$ & 2.04 & 3.04 \\
\hline 21 & G & H8 & 20 & G & H3 ' & 2.93 & 4.43 \\
\hline 21 & $G$ & $\mathrm{H} 1^{\prime}$ & 21 & G & $\mathrm{H} 2^{\prime}$ & 2.30 & 3.30 \\
\hline 21 & $\mathrm{G}$ & H8 & 21 & G & $\mathrm{H} 1^{\prime}$ & 3.07 & 4.07 \\
\hline 21 & G & H8 & 21 & G & $\mathrm{H} 2^{\prime}$ & 1.59 & 2.59 \\
\hline 1 & C & $\mathrm{H} 6$ & 2 & C & $\mathrm{H} 6$ & 3.50 & 5.00 \\
\hline 2 & C & $\mathrm{H} 6$ & 3 & G & H8 & 3.50 & 5.00 \\
\hline 3 & G & H8 & 4 & G & H8 & 5.00 & 6.50 \\
\hline 4 & G & H8 & 5 & C & $\mathrm{H} 6$ & $4.0 \odot$ & 5.50 \\
\hline 5 & $C$ & $\mathrm{H} 6$ & 6 & $A$ & H8 & 4.50 & 6.00 \\
\hline 6 & A & H8 & 7 & G & H8 & 5.00 & 6.50 \\
\hline 7 & $G$ & H8 & 8 & U & $\mathrm{H} 6$ & 3.50 & $5.0 \odot$ \\
\hline 8 & U & $\mathrm{H} 6$ & 9 & G & H8 & 3.50 & 5.00 \\
\hline 9 & $G$ & H8 & 10 & U & H6 & 3.50 & $5.0 \odot$ \\
\hline 10 & U & $\mathrm{H} 6$ & 11 & G & H8 & 3.50 & 5.00 \\
\hline 12 & C & $\mathrm{H} 6$ & 13 & A & H8 & 3.50 & 5.00 \\
\hline 13 & A & H8 & 14 & C & $\mathrm{H} 6$ & 3.50 & $5.0 \odot$ \\
\hline 14 & $C$ & $\mathrm{H} 6$ & 15 & $A$ & H8 & 3.50 & $5.0 \odot$ \\
\hline
\end{tabular}

Supporting Information Page 70 


$\begin{array}{rlrrllll}15 & \text { A } & \text { H8 } & 16 & \text { C } & \text { H6 } & 4.00 & 5.50 \\ 16 & \text { C } & \text { H6 } & 17 & \text { G } & \text { H8 } & 3.50 & 5.00 \\ 17 & \text { G } & \text { H8 } & 18 & \text { U } & \text { H6 } & 3.50 & 5.00 \\ 18 & \text { U } & \text { H6 } & 19 & \text { C } & \text { H6 } & 3.50 & 5.00 \\ 19 & \text { C } & \text { H6 } & 20 & \text { G } & \text { H8 } & 3.50 & 5.00 \\ 20 & \text { G } & \text { H8 } & 21 & \text { G } & \text { H8 } & 3.50 & 5.00 \\ 6 & \text { A } & \text { H2 } & 7 & \text { G } & \text { H1' }^{\prime} & 3.00 & 4.50\end{array}$


Table S10: NOE restraints used for modeling of stem mimic duplex bound to 4 (denoted by F5D).

\begin{tabular}{|c|c|c|c|c|c|c|c|}
\hline 1 & $C$ & $\mathrm{H} 1^{\prime}$ & 1 & C & $\mathrm{H} 2^{\prime}$ & 2.32 & 3.32 \\
\hline 1 & C & $\mathrm{H} 6$ & 1 & C & $\mathrm{H} 1^{\prime}$ & 2.67 & 3.67 \\
\hline 1 & C & $\mathrm{H} 6$ & 1 & C & $\mathrm{H} 2^{\prime}$ & 2.91 & 3.91 \\
\hline 1 & C & H6 & 1 & C & H3 ' & 2.71 & 4.21 \\
\hline 1 & C & $\mathrm{H} 6$ & 1 & C & H5 & 2.40 & 2.60 \\
\hline 1 & C & $\mathrm{H} 6$ & 2 & C & H5 & 3.96 & 5.46 \\
\hline 1 & $C$ & H6 & 2 & C & H6 & 3.50 & 5.00 \\
\hline 2 & $C$ & H6 & 1 & C & $\mathrm{H} 1^{\prime}$ & 3.46 & 4.96 \\
\hline 2 & C & H6 & 1 & C & $\mathrm{H} 2^{\prime}$ & 2.02 & 3.02 \\
\hline 2 & $C$ & $\mathrm{H} 1^{\prime}$ & 2 & C & $\mathrm{H} 2^{\prime}$ & 2.48 & 3.48 \\
\hline 2 & $C$ & H6 & 2 & C & H5 & 2.40 & 2.60 \\
\hline 2 & C & $\mathrm{H} 6$ & 3 & G & H8 & 3.50 & 5.00 \\
\hline 3 & G & H8 & 2 & C & $\mathrm{H} 1^{\prime}$ & 3.79 & 5.29 \\
\hline 3 & $\mathrm{G}$ & H8 & 2 & C & $\mathrm{H} 2^{\prime}$ & 2.50 & 3.50 \\
\hline 3 & $\mathrm{G}$ & $\mathrm{H} 1^{\prime}$ & 3 & G & $\mathrm{H} 2^{\prime}$ & 2.31 & 3.31 \\
\hline 3 & $\mathrm{G}$ & H8 & 3 & G & $\mathrm{H} 1^{\prime}$ & 2.79 & 3.79 \\
\hline 3 & $\mathrm{G}$ & H8 & 4 & G & H8 & 4.75 & 6.75 \\
\hline 4 & $\mathrm{G}$ & H8 & 3 & G & $\mathrm{H} 2^{\prime}$ & 2.19 & 3.69 \\
\hline 4 & $\mathrm{G}$ & H8 & 3 & G & $\mathrm{H}^{\prime}{ }^{\prime}$ & 3.05 & 5.05 \\
\hline 4 & $\mathrm{G}$ & $\mathrm{H} 1^{\prime}$ & 4 & G & $\mathrm{H} 2^{\prime}$ & 2.19 & 3.69 \\
\hline 4 & $\mathrm{G}$ & $\mathrm{H} 1^{\prime}$ & 4 & G & H3 ' & 2.85 & 4.85 \\
\hline 4 & G & H8 & 4 & G & $\mathrm{H} 1^{\prime}$ & 2.76 & 4.26 \\
\hline 4 & G & H8 & 5 & C & H5 & 3.16 & 5.16 \\
\hline 4 & G & H8 & 5 & C & $\mathrm{H} 6$ & 3.75 & 5.75 \\
\hline 5 & $C$ & H6 & 4 & G & $\mathrm{H} 1^{\prime}$ & 4.15 & 6.15 \\
\hline 5 & $C$ & H6 & 4 & G & $\mathrm{H} 2^{\prime}$ & 1.52 & 3.02 \\
\hline 5 & $C$ & H6 & 4 & G & $\mathrm{H}^{\prime}{ }^{\prime}$ & 2.52 & 4.52 \\
\hline 5 & $C$ & $\mathrm{H} 1^{\prime}$ & 5 & C & $\mathrm{H} 2^{\prime}$ & 1.94 & 3.44 \\
\hline 5 & $C$ & $\mathrm{H} 1^{\prime}$ & 5 & C & $\mathrm{H}^{\prime}{ }^{\prime}$ & 2.48 & 4.48 \\
\hline 5 & $C$ & H6 & 5 & C & $\mathrm{H} 1^{\prime}$ & 2.56 & 4.06 \\
\hline 5 & C & H6 & 5 & C & H3 ' & 2.54 & 4.54 \\
\hline 5 & C & H6 & 5 & C & H5 & 2.15 & 2.85 \\
\hline 6 & $A$ & H8 & 5 & C & $\mathrm{H} 2^{\prime}$ & 2.98 & 5.48 \\
\hline 6 & $A$ & H8 & 5 & C & $\mathrm{H}^{\prime}{ }^{\prime}$ & 3.46 & 6.96 \\
\hline 6 & $A$ & $\mathrm{H} 1^{\prime}$ & 6 & $A$ & $\mathrm{H} 2^{\prime}$ & 2.42 & 3.92 \\
\hline 6 & $A$ & $\mathrm{H} 1^{\prime}$ & 6 & A & $\mathrm{H}^{\prime}{ }^{\prime}$ & 2.99 & 4.99 \\
\hline 6 & A & H8 & 6 & A & $\mathrm{H} 1^{\prime}$ & 2.18 & 4.18 \\
\hline 6 & $A$ & H8 & 6 & A & $\mathrm{H} 2^{\prime}$ & 2.01 & 4.01 \\
\hline 7 & $\mathrm{G}$ & $\mathrm{H} 1^{\prime}$ & 7 & G & $\mathrm{H} 2^{\prime}$ & 2.21 & 3.71 \\
\hline 7 & $G$ & $\mathrm{H} 1^{\prime}$ & 7 & G & $\mathrm{H}^{\prime}$ & 3.28 & 5.28 \\
\hline 7 & G & H8 & 7 & G & $\mathrm{H} 1^{\prime}$ & 2.69 & 4.19 \\
\hline 7 & G & H8 & 8 & U & H6 & 3.25 & 5.25 \\
\hline 8 & $U$ & H6 & 7 & G & $\mathrm{H} 1^{\prime}$ & 3.08 & 5.08 \\
\hline 8 & $\mathrm{U}$ & H6 & 7 & G & $\mathrm{H} 2^{\prime}$ & 1.97 & 3.47 \\
\hline 8 & $U$ & H6 & 7 & G & $\mathrm{H}^{\prime}{ }^{\prime}$ & 2.27 & 4.27 \\
\hline 8 & $\mathrm{U}$ & H6 & 8 & U & $\mathrm{H} 1^{\prime}$ & 3.04 & 4.54 \\
\hline 8 & $U$ & H6 & 8 & U & $\mathrm{H} 2^{\prime}$ & 3.17 & 4.17 \\
\hline 8 & $U$ & $\mathrm{H} 6$ & 8 & U & H5 & 2.40 & 2.60 \\
\hline
\end{tabular}

Supporting Information Page 72 


\begin{tabular}{|c|c|c|c|c|c|c|c|}
\hline 9 & G & H8 & 8 & U & $\mathrm{H} 1^{\prime}$ & 3.62 & 5.1 \\
\hline 9 & G & H8 & 8 & U & $\mathrm{H} 2^{\prime}$ & 2.60 & 3.6 \\
\hline 9 & G & $\mathrm{H} 1^{\prime}$ & 9 & G & $\mathrm{H} 2^{\prime}$ & 2.34 & 3 \\
\hline 9 & G & $\mathrm{H}^{\prime}{ }^{\prime}$ & 9 & G & $\mathrm{H}^{\prime}$ & 3.59 & 5. \\
\hline 9 & G & H8 & 9 & G & $\mathrm{H} 1^{\prime}$ & 3.54 & 4.5 \\
\hline 10 & U & H6 & 9 & G & $\mathrm{H} 1^{\prime}$ & 3.64 & 5.1 \\
\hline 10 & U & $\mathrm{H} 1^{\prime}$ & 10 & $U$ & $\mathrm{H} 2^{\prime}$ & 2.27 & 3.2 \\
\hline 10 & U & $\mathrm{H} 1^{\prime}$ & 10 & U & $\mathrm{H} 3^{\prime}$ & 3.07 & 4 \\
\hline 10 & U & H6 & 10 & U & $\mathrm{H} 1^{\prime}$ & 2.90 & 3 \\
\hline 10 & U & H6 & 10 & U & H5 & 2.40 & 2. \\
\hline 11 & G & H8 & 10 & U & $\mathrm{H} 1^{\prime}$ & 3.24 & 4 \\
\hline 11 & G & H8 & 10 & $U$ & $\mathrm{H} 2^{\prime}$ & 1.91 & 2.5 \\
\hline 11 & G & $\mathrm{H} 1^{\prime}$ & 11 & G & $\mathrm{H} 2^{\prime}$ & 2.42 & 3.2 \\
\hline 11 & G & $\mathrm{H} 1^{\prime}$ & 11 & G & $\mathrm{H}^{\prime}$ & 3.43 & 4.5 \\
\hline 11 & G & H8 & 11 & G & $\mathrm{H} 1^{\prime}$ & 2.94 & 3. \\
\hline 11 & G & H8 & 11 & G & $\mathrm{H} 2^{\prime}$ & 2.86 & $3 . \varepsilon$ \\
\hline 11 & G & H8 & 11 & G & $\mathrm{H} 3^{\prime}$ & 3.40 & 4 \\
\hline 12 & C & $\mathrm{H} 1^{\prime}$ & 12 & C & $\mathrm{H} 2^{\prime}$ & 2.66 & 3.6 \\
\hline 12 & C & H6 & 12 & C & $\mathrm{H} 1^{\prime}$ & 2.97 & 3 \\
\hline 12 & C & H6 & 12 & C & $\mathrm{H} 2^{\prime}$ & 2.84 & $3 . \varepsilon$ \\
\hline 12 & C & H6 & 12 & C & H3 ' & 2.65 & 4.1 \\
\hline 12 & C & $\mathrm{H} 6$ & 12 & C & H5 & 2.40 & 2.6 \\
\hline 13 & A & $\mathrm{H} 2$ & 11 & G & $\mathrm{H} 1^{\prime}$ & 2.99 & $3 . c$ \\
\hline 13 & A & H8 & 12 & C & $\mathrm{H} 1^{\prime}$ & 4.23 & 5.7 \\
\hline 13 & A & H8 & 12 & C & $\mathrm{H} 2^{\prime}$ & 2.17 & 3 \\
\hline 13 & A & H8 & 12 & C & H3 ${ }^{\prime}$ & 2.83 & 4 \\
\hline 13 & A & $\mathrm{H} 1^{\prime}$ & 13 & A & $\mathrm{H} 2^{\prime}$ & 2.42 & 3. \\
\hline 13 & A & $\mathrm{H} 1^{\prime}$ & 13 & A & $\mathrm{H} 3^{\prime}$ & 3.44 & 4.5 \\
\hline 13 & A & $\mathrm{H} 2$ & 13 & A & $\mathrm{H} 1^{\prime}$ & 3.75 & 4.7 \\
\hline 13 & A & H8 & 13 & A & $\mathrm{H} 1^{\prime}$ & 3.27 & 4.2 \\
\hline 13 & A & H8 & 13 & A & H3 ${ }^{\prime}$ & 3.00 & 4.5 \\
\hline 13 & A & H8 & 14 & C & H5 & 3.61 & 5.1 \\
\hline 14 & C & H5 & 13 & A & $\mathrm{H} 2^{\prime}$ & 3.71 & 5. \\
\hline 14 & C & H5 & 13 & A & H3 ' & 2.64 & 4. \\
\hline 14 & C & H6 & 13 & A & $\mathrm{H} 1^{\prime}$ & 3.58 & 5. \\
\hline 14 & C & H6 & 13 & A & $\mathrm{H} 2^{\prime}$ & 1.88 & 2. \\
\hline 14 & C & $\mathrm{H} 6$ & 13 & A & $\mathrm{H}^{\prime}{ }^{\prime}$ & 3.06 & 4 \\
\hline 14 & C & $\mathrm{H} 1^{\prime}$ & 14 & C & $\mathrm{H} 2^{\prime}$ & 2.16 & 3 \\
\hline 14 & C & $\mathrm{H} 1^{\prime}$ & 14 & C & $\mathrm{H} 3^{\prime}$ & 3.65 & 5.1 \\
\hline 14 & C & H6 & 14 & C & $\mathrm{H} 1^{\prime}$ & 2.84 & 3.8 \\
\hline 14 & C & H6 & 14 & C & $\mathrm{H} 2^{\prime}$ & 3.04 & 4. \\
\hline 14 & C & H6 & 14 & C & H5 & 2.40 & 2.6 \\
\hline 15 & A & $\mathrm{H} 2$ & 9 & G & $\mathrm{H} 1^{\prime}$ & 3.03 & 4. \\
\hline 15 & A & H8 & 14 & C & $\mathrm{H} 1^{\prime}$ & 3.29 & 4.7 \\
\hline 15 & A & H8 & 14 & C & $\mathrm{H} 2^{\prime}$ & 2.07 & 3. \\
\hline 15 & A & H8 & 14 & C & $\mathrm{H}^{\prime}$ & 3.11 & 4.6 \\
\hline 15 & A & H8 & 14 & C & H5 & 4.18 & 5.6 \\
\hline 15 & A & $\mathrm{H} 1^{\prime}$ & 15 & A & $\mathrm{H} 2^{\prime}$ & 2.51 & 3.5 \\
\hline 15 & A & $\mathrm{H} 2$ & 15 & A & $\mathrm{H} 1^{\prime}$ & 4.00 & 6.6 \\
\hline 15 & A & H8 & 15 & A & $\mathrm{H} 1^{\prime}$ & 3.43 & 4.4 \\
\hline 15 & A & $\mathrm{H} 2$ & 16 & C & $\mathrm{H} 1^{\prime}$ & 3.05 & 4.5 \\
\hline 15 & A & H8 & 16 & C & H5 & 3.90 & 5.90 \\
\hline
\end{tabular}

Supporting Information Page 73 


\begin{tabular}{|c|c|c|c|c|c|c|c|}
\hline 15 & A & H8 & 16 & C & $\mathrm{H} 6$ & 3.75 & 5.75 \\
\hline 16 & $C$ & $\mathrm{H} 6$ & 15 & A & $\mathrm{H} 1^{\prime}$ & 3.17 & 5.17 \\
\hline 16 & C & $\mathrm{H} 6$ & 15 & A & H2 ' & 1.77 & 3.27 \\
\hline 16 & C & $\mathrm{H} 6$ & 15 & A & H3 ' & 2.05 & 4.05 \\
\hline 16 & C & $\mathrm{H} 1^{\prime}$ & 16 & C & $\mathrm{H} 2^{\prime}$ & 2.27 & 3.77 \\
\hline 16 & C & $\mathrm{H} 1^{\prime}$ & 16 & C & H3 ' & 2.03 & 4.03 \\
\hline 16 & C & $\mathrm{H} 6$ & 16 & C & $\mathrm{H} 1^{\prime}$ & 2.72 & 4.22 \\
\hline 16 & C & $\mathrm{H} 6$ & 16 & C & H5 & 2.15 & 2.8 \\
\hline 17 & $\mathrm{G}$ & H8 & 16 & C & $\mathrm{H} 1^{\prime}$ & 3.85 & 6.8 \\
\hline 17 & $\mathrm{G}$ & H8 & 16 & C & H2 ' & 2.82 & 5.3 \\
\hline 17 & $\mathrm{G}$ & $\mathrm{H} 1^{\prime}$ & 17 & G & H2 ' & 2.09 & 3.5 \\
\hline 17 & G & H8 & 17 & G & $\mathrm{H} 1^{\prime}$ & 2.91 & 4.4 \\
\hline 17 & $\mathrm{G}$ & H8 & 17 & G & H3 ' & 2.47 & 4.4 \\
\hline 17 & G & H8 & 18 & U & $\mathrm{H} 6$ & 3.25 & 5.2 \\
\hline 18 & U & H5 & 17 & G & H2 ' & 4.02 & 6.0 \\
\hline 18 & U & $\mathrm{H} 6$ & 17 & G & $\mathrm{H} 1^{\prime}$ & 3.62 & 5.6 \\
\hline 18 & U & $\mathrm{H} 6$ & 17 & G & H2 ' & 1.89 & 3.3 \\
\hline 18 & U & $\mathrm{H} 6$ & 17 & G & H3 ' & 2.47 & 4.4 \\
\hline 18 & U & $\mathrm{H} 1^{\prime}$ & 18 & U & H2 ' & 2.07 & 3.5 \\
\hline 18 & U & $\mathrm{H} 6$ & 18 & U & $\mathrm{H} 1^{\prime}$ & 2.75 & 4.2 \\
\hline 18 & U & $\mathrm{H} 6$ & 18 & U & H2' & 2.51 & 4.0 \\
\hline 18 & U & $\mathrm{H} 6$ & 18 & U & H3 ' & 2.33 & 4.3 \\
\hline 18 & U & H6 & 18 & U & H5 & 2.15 & 2.8 \\
\hline 19 & C & $\mathrm{H} 6$ & 18 & U & H1' & 3.64 & 5.6 \\
\hline 19 & C & $\mathrm{H} 6$ & 18 & $U$ & H2 ' & 1.65 & 3.1 \\
\hline 19 & C & $\mathrm{H} 1^{\prime}$ & 19 & C & $\mathrm{H} 2^{\prime}$ & 2.64 & 3.6 \\
\hline 19 & C & $\mathrm{H} 1^{\prime}$ & 19 & C & H3 ' & 2.74 & 4.2 \\
\hline 19 & C & $\mathrm{H} 6$ & 19 & C & $\mathrm{H} 1^{\prime}$ & 3.07 & 4.0 \\
\hline 19 & C & $\mathrm{H} 6$ & 19 & C & H5 & 2.40 & 2.6 \\
\hline 19 & C & $\mathrm{H} 6$ & 20 & G & H8 & 3.03 & 4.5 \\
\hline 20 & G & H8 & 19 & C & $\mathrm{H} 1^{\prime}$ & 3.49 & 4.5 \\
\hline 20 & G & H8 & 19 & C & H2 ' & 1.90 & 2.9 \\
\hline 20 & G & H8 & 19 & C & H3 ' & 3.63 & 5.1 \\
\hline 20 & G & $\mathrm{H} 1^{\prime}$ & 20 & G & H2 ' & 2.10 & 3.1 \\
\hline 20 & G & H8 & 20 & G & $\mathrm{H} 1^{\prime}$ & 3.01 & 4.0 \\
\hline 20 & G & H8 & 21 & G & H8 & 3.50 & 5.0 \\
\hline 21 & G & H8 & 20 & G & $\mathrm{H} 1^{\prime}$ & 4.00 & 5.5 \\
\hline 21 & G & H8 & 20 & G & H2 ' & 2.04 & 3.0 \\
\hline 21 & G & H8 & 20 & G & H3 ' & 2.93 & 4.4 \\
\hline 21 & G & $\mathrm{H} 1^{\prime}$ & 21 & G & H2 ' & 2.30 & 3.30 \\
\hline 21 & G & H8 & 21 & G & $\mathrm{H} 1^{\prime}$ & 3.07 & 4.0 \\
\hline 21 & G & H8 & 21 & G & H2 ' & 1.59 & 2.50 \\
\hline 22 & F5D & C7 & 22 & F5D & $\mathrm{H} 4$ & 2.4 & 3.2 \\
\hline 22 & F5D & C7' & 22 & F5D & H4 ' & 2.4 & 3.2 \\
\hline 22 & F5D & $\mathrm{H} 4^{\prime}$ & 16 & C & $\mathrm{H} 2^{\prime}$ & 2.0 & 4.0 \\
\hline 22 & F5D & $\mathrm{H} 44^{\prime}$ & 16 & C & $\mathrm{H} 1^{\prime}$ & 2.5 & 4.5 \\
\hline 22 & F5D & C7 & 5 & C & H3 ' & 2.0 & 4.0 \\
\hline 22 & F5D & C7 & 5 & C & H5 & 2.0 & 4.0 \\
\hline 22 & F5D & C7' & 16 & C & $\mathrm{H} 2^{\prime}$ & 2.0 & 4.0 \\
\hline 22 & F5D & C7 & 6 & A & H5 ' ' & 2.5 & 5.0 \\
\hline 22 & F5D & $C 7^{\prime}$ & 17 & G & $\mathrm{H} 1^{\prime}$ & 2.5 & 5 \\
\hline
\end{tabular}

Supporting Information Page 74 
Table S11: NOE restraints used for modeling of stem mimic duplex bound to $\mathbf{5}$ (denoted by PFA).

\begin{tabular}{|c|c|c|c|c|c|c|c|}
\hline 1 & RC5 & $\mathrm{H} 1^{\prime}$ & 1 & RC5 & $\mathrm{H} 2^{\prime}$ & 2.4 & 3.1 \\
\hline 1 & RC5 & $\mathrm{H} 1^{\prime}$ & 1 & RC5 & $\mathrm{H} 3^{\prime}$ & 3.4 & 4.2 \\
\hline 1 & RC5 & $\mathrm{H} 1^{\prime}$ & 1 & RC5 & $\mathrm{H} 4^{\prime}$ & 3.2 & 3.7 \\
\hline 1 & RC5 & H5 & 1 & RC5 & $\mathrm{H} 2^{\prime}$ & 3.9 & 5.1 \\
\hline 1 & RC5 & H5 & 1 & RC5 & H3 ' & 3.9 & 5.1 \\
\hline 1 & RC5 & H6 & 1 & RC5 & $\mathrm{H} 1^{\prime}$ & 3.4 & 4.6 \\
\hline 1 & RC5 & H6 & 1 & RC5 & $\mathrm{H} 2^{\prime}$ & 3.4 & 4.6 \\
\hline 1 & RC5 & H6 & 1 & RC5 & H3 ' & 2.4 & 4.1 \\
\hline 1 & RC5 & H6 & 2 & $\mathrm{RC}$ & H5 & 3.4 & 4.6 \\
\hline 1 & RC5 & N3 & 21 & RG3 & $\mathrm{H} 1$ & 1.8 & 2.4 \\
\hline 1 & RC5 & H41 & 21 & RG3 & 06 & 1.8 & 2.4 \\
\hline 1 & RC5 & 02 & 21 & RG & H22 & 1.8 & 2.4 \\
\hline 1 & RC5 & N1 & 21 & RG3 & N9 & 8.6 & 9.0 \\
\hline 2 & $\mathrm{RC}$ & $\mathrm{H} 1^{\prime}$ & 2 & $\mathrm{RC}$ & $\mathrm{H} 2^{\prime}$ & 2.4 & 3.1 \\
\hline 2 & $\mathrm{RC}$ & $\mathrm{H} 1^{\prime}$ & 2 & $\mathrm{RC}$ & H3 ' & 3.4 & 4.2 \\
\hline 2 & $\mathrm{RC}$ & H5 & 2 & $\mathrm{RC}$ & $\mathrm{H} 2^{\prime}$ & 3.9 & 5.1 \\
\hline 2 & $\mathrm{RC}$ & H5 & 1 & RC5 & $\mathrm{H} 2^{\prime}$ & 2.9 & 4.6 \\
\hline 2 & $\mathrm{RC}$ & H5 & 2 & $\mathrm{RC}$ & $\mathrm{H}^{\prime}{ }^{\prime}$ & 3.9 & 5.1 \\
\hline 2 & $\mathrm{RC}$ & H5 & 1 & RC5 & H3 ' & 2.9 & 4.1 \\
\hline 2 & $\mathrm{RC}$ & H6 & 1 & RC5 & $\mathrm{H} 1^{\prime}$ & 3.9 & 5.1 \\
\hline 2 & $\mathrm{RC}$ & H6 & 2 & $\mathrm{RC}$ & $\mathrm{H} 2^{\prime}$ & 3.4 & 4.6 \\
\hline 2 & $\mathrm{RC}$ & H6 & 2 & $\mathrm{RC}$ & H3 ' & 2.9 & 4.1 \\
\hline 2 & $\mathrm{RC}$ & H6 & 1 & RC5 & H3 ' & 2.9 & 4.1 \\
\hline 2 & $\mathrm{RC}$ & H6 & 1 & RC5 & H5 & 3.4 & 4.6 \\
\hline 2 & $\mathrm{RC}$ & H6 & 1 & RC5 & $\mathrm{H} 2^{\prime}$ & 2.0 & 2.7 \\
\hline 2 & $\mathrm{RC}$ & H6 & 2 & $\mathrm{RC}$ & $\mathrm{H} 1^{\prime}$ & 3.4 & 4.7 \\
\hline 2 & $\mathrm{RC}$ & N3 & 20 & $R G$ & $\mathrm{H} 1$ & 1.8 & 2.4 \\
\hline 2 & $\mathrm{RC}$ & $\mathrm{H} 41$ & 20 & $R G$ & 06 & 1.8 & 2.4 \\
\hline 2 & $\mathrm{RC}$ & 02 & 20 & $R G$ & $\mathrm{H} 22$ & 1.8 & 2.4 \\
\hline 2 & $\mathrm{RC}$ & N1 & 20 & $R G$ & N9 & 8.6 & 9.0 \\
\hline 3 & RG & $\mathrm{H} 1^{\prime}$ & 3 & RG & $\mathrm{H} 2^{\prime}$ & 2.4 & 3.1 \\
\hline 3 & RG & $\mathrm{H} 1^{\prime}$ & 3 & $R G$ & $\mathrm{H} 4^{\prime}$ & 3.2 & 3.7 \\
\hline 3 & RG & H8 & 2 & $\mathrm{RC}$ & $\mathrm{H} 1^{\prime}$ & 3.9 & 5.1 \\
\hline 3 & RG & H8 & 3 & $R G$ & $\mathrm{H} 1^{\prime}$ & 3.1 & 4.1 \\
\hline 3 & RG & H8 & 3 & $R G$ & $\mathrm{H} 2^{\prime}$ & 3.8 & 4.5 \\
\hline 3 & RG & H8 & 2 & $\mathrm{RC}$ & $\mathrm{H} 2^{\prime}$ & 1.9 & 2.6 \\
\hline 3 & RG & H8 & 2 & $\mathrm{RC}$ & $\mathrm{H} 3^{\prime}$ & 2.6 & 3.6 \\
\hline 3 & RG & $\mathrm{H} 1$ & 19 & $\mathrm{RC}$ & N3 & 1.8 & 2.4 \\
\hline 3 & RG & 06 & 19 & $\mathrm{RC}$ & $\mathrm{H} 41$ & 1.8 & 2.4 \\
\hline 3 & RG & $\mathrm{H} 22$ & 19 & $\mathrm{RC}$ & 02 & 1.8 & 2.4 \\
\hline 4 & RG & $\mathrm{H} 1^{\prime}$ & 4 & $R G$ & $\mathrm{H} 2^{\prime}$ & 2.4 & 3.1 \\
\hline 4 & RG & $\mathrm{H}^{\prime}{ }^{\prime}$ & 4 & $R G$ & H3 ' & 3.4 & 4.2 \\
\hline 4 & RG & $\mathrm{H}^{\prime}{ }^{\prime}$ & 4 & RG & $\mathrm{H} 4^{\prime}$ & 3.2 & 3.7 \\
\hline 4 & $R G$ & H8 & 3 & $R G$ & $\mathrm{H} 1^{\prime}$ & 3.9 & 5.1 \\
\hline 4 & RG & H8 & 4 & $R G$ & $\mathrm{H}^{\prime}{ }^{\prime}$ & 3.1 & 4.1 \\
\hline 4 & RG & H8 & 4 & $R G$ & $\mathrm{H} 2^{\prime}$ & 3.8 & 4.5 \\
\hline 4 & RG & H8 & 3 & $R G$ & $\mathrm{H} 2^{\prime}$ & 1.9 & 2.6 \\
\hline 4 & $R G$ & $\mathrm{H} 8$ & 4 & $R G$ & $\mathrm{H}^{\prime}$ & 2.6 & 3.6 \\
\hline
\end{tabular}




\begin{tabular}{|c|c|c|c|c|c|c|c|}
\hline 4 & $\mathrm{RG}$ & H8 & 4 & RG & $\mathrm{H} 4^{\prime}$ & 3.4 & 4.6 \\
\hline 4 & $\mathrm{RG}$ & H8 & 5 & $\mathrm{RC}$ & H5 & 3.4 & 4.6 \\
\hline 4 & $R G$ & $\mathrm{H} 1$ & 18 & RU & 02 & 1.8 & 2.4 \\
\hline 4 & RG & 06 & 18 & RU & H3 & 1.8 & 2.4 \\
\hline 5 & $\mathrm{RC}$ & $\mathrm{H} 1^{\prime}$ & 5 & $\mathrm{RC}$ & $\mathrm{H} 2^{\prime}$ & 2.4 & 3.1 \\
\hline 5 & $\mathrm{RC}$ & H5 & 5 & $\mathrm{RC}$ & $\mathrm{H} 2^{\prime}$ & 3.9 & 5.1 \\
\hline 5 & $\mathrm{RC}$ & H5 & 4 & $R G$ & $\mathrm{H} 2^{\prime}$ & 2.9 & 4.6 \\
\hline 5 & $\mathrm{RC}$ & H5 & 4 & $R G$ & H3 ' & 2.9 & 4.1 \\
\hline 5 & $\mathrm{RC}$ & H6 & 4 & RG & $\mathrm{H} 1^{\prime}$ & 3.9 & 5.1 \\
\hline 5 & $\mathrm{RC}$ & H6 & 5 & $\mathrm{RC}$ & $\mathrm{H}^{\prime}{ }^{\prime}$ & 3.4 & 4.3 \\
\hline 5 & $\mathrm{RC}$ & H6 & 5 & $\mathrm{RC}$ & $\mathrm{H} 2^{\prime}$ & 3.4 & 4.6 \\
\hline 5 & $\mathrm{RC}$ & H6 & 4 & $R G$ & $\mathrm{H} 2^{\prime}$ & 1.9 & 3.1 \\
\hline 5 & $\mathrm{RC}$ & H6 & 4 & $R G$ & H3 ' & 2.9 & 4.1 \\
\hline 5 & $\mathrm{RC}$ & N3 & 17 & $R G$ & H1 & 1.8 & 2.4 \\
\hline 5 & $\mathrm{RC}$ & H41 & 17 & $\mathrm{RG}$ & 06 & 1.8 & 2.4 \\
\hline 5 & $\mathrm{RC}$ & 02 & 17 & $\mathrm{RG}$ & $\mathrm{H} 22$ & 1.8 & 2.4 \\
\hline 5 & $\mathrm{RC}$ & N1 & 17 & RG3 & N9 & 8.6 & 9.0 \\
\hline 6 & RA & $\mathrm{H} 1^{\prime}$ & 6 & RA & $\mathrm{H} 2^{\prime}$ & 2.4 & 3.1 \\
\hline 6 & RA & $\mathrm{H} 1^{\prime}$ & 6 & RA & $\mathrm{H} 3^{\prime}$ & 3.4 & 4.2 \\
\hline 6 & RA & $\mathrm{H}^{\prime}{ }^{\prime}$ & 6 & RA & $\mathrm{H} 2^{\prime}$ & 2.2 & 3.1 \\
\hline 6 & RA & H8 & 5 & $\mathrm{RC}$ & $\mathrm{H} 1^{\prime}$ & 3.4 & 5.1 \\
\hline 6 & RA & H8 & 6 & RA & $\mathrm{H} 1^{\prime}$ & 3.1 & 4.6 \\
\hline 6 & RA & H8 & 6 & RA & $\mathrm{H} 2^{\prime}$ & 2.9 & 5.1 \\
\hline 7 & $R G$ & $\mathrm{H} 1^{\prime}$ & 7 & RG & $\mathrm{H} 2^{\prime}$ & 2.4 & 3.1 \\
\hline 7 & $R G$ & H8 & 6 & RA & $\mathrm{H} 1^{\prime}$ & 3.1 & 5.1 \\
\hline 7 & RG & H8 & 7 & RG & $\mathrm{H} 1^{\prime}$ & 3.1 & 4.1 \\
\hline 7 & RG & H8 & 7 & RG & $\mathrm{H} 2^{\prime}$ & 3.8 & 4.5 \\
\hline 7 & $R G$ & H8 & 6 & RA & $\mathrm{H} 3^{\prime}$ & 2.6 & 3.6 \\
\hline 7 & $R G$ & H8 & 8 & RU & H5 & 3.4 & 4.6 \\
\hline 7 & $R G$ & $\mathrm{H} 1$ & 16 & $\mathrm{RC}$ & N3 & 1.8 & 2.4 \\
\hline 7 & RG & 06 & 16 & $\mathrm{RC}$ & $\mathrm{H} 41$ & 1.8 & 2.4 \\
\hline 7 & $\mathrm{RG}$ & $\mathrm{H} 22$ & 16 & $\mathrm{RC}$ & 02 & 1.8 & 2.4 \\
\hline 8 & RU & $\mathrm{H} 1^{\prime}$ & 8 & RU & $\mathrm{H} 3^{\prime}$ & 3.4 & 4.2 \\
\hline 8 & RU & H5 & 7 & RG & $\mathrm{H} 2^{\prime}$ & 2.9 & 4.6 \\
\hline 8 & RU & H5 & 8 & $R U$ & H3 ' & 3.9 & 5.1 \\
\hline 8 & RU & H6 & 7 & RG & $\mathrm{H} 1^{\prime}$ & 3.9 & 5.1 \\
\hline 8 & RU & H6 & 8 & RU & $\mathrm{H} 1^{\prime}$ & 3.4 & 4.3 \\
\hline 8 & RU & H6 & 7 & RG & $\mathrm{H} 2^{\prime}$ & 1.9 & 3.1 \\
\hline 8 & RU & H6 & 7 & $\mathrm{RG}$ & $\mathrm{H} 3^{\prime}$ & 2.9 & 4.1 \\
\hline 8 & RU & $\mathrm{H} 6$ & 8 & $\mathrm{RU}$ & $\mathrm{H}^{\prime}$ & 2.9 & 4.1 \\
\hline 8 & RU & H3 & 15 & RA & N1 & 1.8 & 2.4 \\
\hline 8 & RU & 04 & 15 & RA & H61 & 1.8 & 2.4 \\
\hline 8 & RU & N1 & 15 & RA & N9 & 8.6 & 9.0 \\
\hline 9 & RG & $\mathrm{H} 1^{\prime}$ & 9 & RG & $\mathrm{H} 2^{\prime}$ & 2.4 & 3.1 \\
\hline 9 & RG & $\mathrm{H} 1^{\prime}$ & 9 & RG & H3 ' & 3.4 & 4.2 \\
\hline 9 & $R G$ & $\mathrm{H} 1^{\prime}$ & 9 & RG & $\mathrm{H} 4^{\prime}$ & 3.2 & 3.7 \\
\hline 9 & RG & H8 & 8 & RU & $\mathrm{H} 1^{\prime}$ & 3.9 & 5.1 \\
\hline 9 & $R G$ & H8 & 9 & RG & $\mathrm{H} 1^{\prime}$ & 3.1 & 4.1 \\
\hline 9 & RG & H8 & 9 & RG & H3 ' & 2.6 & 3.6 \\
\hline 9 & $\mathrm{RG}$ & H8 & 8 & $\mathrm{RU}$ & $\mathrm{H}^{\prime}$ & 2.6 & 3.6 \\
\hline 9 & RG & H8 & 10 & RU & H5 & 3.4 & 4.6 \\
\hline 9 & RG & $\mathrm{H} 1$ & 14 & $\mathrm{RC}$ & N3 & 1.8 & 2.4 \\
\hline
\end{tabular}




\begin{tabular}{|c|c|c|c|c|c|c|c|}
\hline 9 & RG & 06 & 14 & $\mathrm{RC}$ & H41 & 1.8 & 2.4 \\
\hline 9 & RG & $\mathrm{H} 22$ & 14 & $\mathrm{RC}$ & 02 & 1.8 & 2.4 \\
\hline 10 & RU & $\mathrm{H} 1^{\prime}$ & 10 & RU & $\mathrm{H}^{\prime}{ }^{\prime}$ & 3.4 & 4.2 \\
\hline 10 & RU & $\mathrm{H} 1^{\prime}$ & 10 & RU & $\mathrm{H} 4^{\prime}$ & 3.2 & 3.7 \\
\hline 10 & RU & H5 & 10 & $\mathrm{RU}$ & $\mathrm{H} 2^{\prime}$ & 3.9 & 5.1 \\
\hline 10 & $R U$ & H5 & 9 & RG & $\mathrm{H} 2^{\prime}$ & 2.9 & 4.6 \\
\hline 10 & RU & H5 & 10 & RU & $\mathrm{H}^{\prime}$ & 3.9 & 5.1 \\
\hline 10 & RU & H5 & 9 & $R G$ & $\mathrm{H}^{\prime}{ }^{\prime}$ & 2.9 & 4.1 \\
\hline 10 & RU & H6 & 9 & RG & $\mathrm{H} 1^{\prime}$ & 3.9 & 5.1 \\
\hline 10 & RU & H6 & 10 & RU & $\mathrm{H} 1^{\prime}$ & 3.4 & 4.3 \\
\hline 10 & $R U$ & H6 & 9 & RG & H3 ' & 2.9 & 4.1 \\
\hline 10 & RU & H6 & 9 & RG & $\mathrm{H} 2^{\prime}$ & 2.0 & 2.7 \\
\hline 10 & RU & $\mathrm{H} 1^{\prime}$ & 10 & RU & $\mathrm{H} 2^{\prime}$ & 2.0 & 2.7 \\
\hline 10 & RU & H3 & 13 & RA & N1 & 1.8 & 2.4 \\
\hline 10 & $R U$ & 04 & 13 & RA & H61 & 1.8 & 2.4 \\
\hline 10 & $R U$ & N1 & 13 & RA & N9 & 8.6 & 9.0 \\
\hline 11 & RG5 & $\mathrm{H} 1^{\prime}$ & 11 & RG5 & $\mathrm{H} 2^{\prime}$ & 2.4 & 3.1 \\
\hline 11 & RG5 & $\mathrm{H}^{\prime}{ }^{\prime}$ & 11 & RG5 & H3 ' & 3.4 & 4.2 \\
\hline 11 & RG5 & $\mathrm{H} 1^{\prime}$ & 11 & RG5 & $\mathrm{H} 4^{\prime}$ & 3.2 & 3.7 \\
\hline 11 & RG5 & H8 & 10 & $\mathrm{RU}$ & $\mathrm{H} 1^{\prime}$ & 3.9 & 5.1 \\
\hline 11 & RG5 & H8 & 11 & RG5 & $\mathrm{H} 1^{\prime}$ & 3.1 & 4.1 \\
\hline 11 & RG5 & H8 & 11 & RG5 & $\mathrm{H} 2^{\prime}$ & 3.8 & 4.5 \\
\hline 11 & RG5 & H8 & 10 & RU & $\mathrm{H}^{\prime}{ }^{\prime}$ & 2.6 & 3.6 \\
\hline 11 & RG5 & H8 & 11 & RG5 & H3 ' & 2.4 & 3.6 \\
\hline 11 & RG5 & H8 & 10 & $\mathrm{RU}$ & $\mathrm{H} 2^{\prime}$ & 1.9 & 2.7 \\
\hline 11 & RG3 & H1 & 12 & RC5 & N3 & 1.8 & 2.4 \\
\hline 11 & RG3 & 06 & 12 & RC5 & H41 & 1.8 & 2.4 \\
\hline 11 & RG3 & $\mathrm{H} 22$ & 12 & RC5 & 02 & 1.8 & 2.4 \\
\hline 12 & RC3 & $\mathrm{H} 1^{\prime}$ & 12 & RC3 & $\mathrm{H} 2^{\prime}$ & 2.4 & 3.1 \\
\hline 12 & RC3 & $\mathrm{H} 1^{\prime}$ & 12 & RC3 & $\mathrm{H}^{\prime}{ }^{\prime}$ & 3.4 & 4.2 \\
\hline 12 & RC3 & $\mathrm{H} 1^{\prime}$ & 12 & RC3 & $\mathrm{H} 4^{\prime}$ & 3.2 & 3.7 \\
\hline 12 & RC3 & H5 & 12 & RC3 & $\mathrm{H} 2^{\prime}$ & 3.9 & 5.1 \\
\hline 12 & RC3 & H5 & 12 & RC3 & H3 ' & 3.9 & 5.1 \\
\hline 12 & RC3 & H6 & 12 & RC3 & $\mathrm{H} 1^{\prime}$ & 3.4 & 4.3 \\
\hline 12 & RC3 & H6 & 12 & RC3 & H5 & 2.4 & 3.6 \\
\hline 13 & RA & $\mathrm{H} 1^{\prime}$ & 13 & RA & $\mathrm{H} 2^{\prime}$ & 2.4 & 3.1 \\
\hline 13 & RA & $\mathrm{H} 1^{\prime}$ & 13 & RA & H3 ' & 3.4 & 4.2 \\
\hline 13 & RA & $\mathrm{H} 2$ & 13 & RA & $\mathrm{H} 1^{\prime}$ & 3.9 & 4.7 \\
\hline 13 & RA & $\mathrm{H} 2$ & 11 & RG5 & $\mathrm{H} 1^{\prime}$ & 3.9 & 5.1 \\
\hline 13 & RA & $\mathrm{H} 2$ & 14 & $\mathrm{RC}$ & $\mathrm{H} 1^{\prime}$ & 3.9 & 5.1 \\
\hline 13 & RA & H8 & 12 & RC3 & $\mathrm{H} 1^{\prime}$ & 3.9 & 5.1 \\
\hline 13 & RA & H8 & 13 & RA & $\mathrm{H} 1^{\prime}$ & 3.1 & 4.1 \\
\hline 13 & RA & H8 & 13 & RA & $\mathrm{H} 2^{\prime}$ & 3.8 & 4.5 \\
\hline 13 & RA & H8 & 12 & RC3 & $\mathrm{H}^{\prime}{ }^{\prime}$ & 2.6 & 3.6 \\
\hline 13 & RA & H8 & 13 & RA & $\mathrm{H}^{\prime}{ }^{\prime}$ & 2.6 & 3.6 \\
\hline 13 & RA & H8 & 12 & RC3 & H5 & 3.4 & 4.6 \\
\hline 13 & RA & H8 & 14 & $\mathrm{RC}$ & H5 & 3.4 & 4.6 \\
\hline 13 & RA & H8 & 12 & RC3 & $\mathrm{H} 2^{\prime}$ & 2.0 & 2.7 \\
\hline 14 & $\mathrm{RC}$ & $\mathrm{H} 1^{\prime}$ & 14 & $\mathrm{RC}$ & $\mathrm{H} 2^{\prime}$ & 2.4 & 3.1 \\
\hline 14 & $\mathrm{RC}$ & $\mathrm{H} 1^{\prime}$ & 14 & $\mathrm{RC}$ & $\mathrm{H}^{\prime}{ }^{\prime}$ & 3.4 & 4.2 \\
\hline 14 & $\mathrm{RC}$ & $\mathrm{H} 1^{\prime}$ & 14 & $\mathrm{RC}$ & $\mathrm{H} 4^{\prime}$ & 3.2 & 3.7 \\
\hline 14 & $\mathrm{RC}$ & H5 & 14 & $\mathrm{RC}$ & $\mathrm{H} 2^{\prime}$ & 3.9 & 5.1 \\
\hline
\end{tabular}




\begin{tabular}{|c|c|c|c|c|c|c|c|}
\hline 14 & $\mathrm{RC}$ & H5 & 13 & RA & $\mathrm{H} 2^{\prime}$ & 2.9 & 4.6 \\
\hline 14 & $\mathrm{RC}$ & H5 & 13 & RA & $\mathrm{H}^{\prime}{ }^{\prime}$ & 2.9 & 4.1 \\
\hline 14 & $\mathrm{RC}$ & H5 & 14 & $\mathrm{RC}$ & $\mathrm{H}^{\prime}{ }^{\prime}$ & 3.9 & 5.1 \\
\hline 14 & $\mathrm{RC}$ & H6 & 13 & RA & $\mathrm{H} 1^{\prime}$ & 3.9 & 5.1 \\
\hline 14 & $\mathrm{RC}$ & H6 & 14 & $\mathrm{RC}$ & $\mathrm{H} 1^{\prime}$ & 3.4 & 4.3 \\
\hline 14 & $\mathrm{RC}$ & H6 & 14 & $\mathrm{RC}$ & $\mathrm{H} 2^{\prime}$ & 3.4 & 4.6 \\
\hline 14 & $\mathrm{RC}$ & $\mathrm{H} 6$ & 13 & RA & $\mathrm{H}^{\prime}{ }^{\prime}$ & 2.9 & 4.1 \\
\hline 14 & $\mathrm{RC}$ & $\mathrm{H} 6$ & 13 & RA & $\mathrm{H} 2^{\prime}$ & 2.0 & 2.7 \\
\hline 14 & $\mathrm{RC}$ & $\mathrm{H} 6$ & 14 & $\mathrm{RC}$ & $\mathrm{H}^{\prime}{ }^{\prime}$ & 2.0 & 2.7 \\
\hline 14 & $\mathrm{RC}$ & N1 & 9 & RG & N9 & 8.6 & 9.0 \\
\hline 15 & RA & $\mathrm{H} 1^{\prime}$ & 15 & RA & $\mathrm{H} 2^{\prime}$ & 2.4 & 3.1 \\
\hline 15 & RA & $\mathrm{H} 1^{\prime}$ & 15 & RA & $\mathrm{H}^{\prime}{ }^{\prime}$ & 3.4 & 4.2 \\
\hline 15 & RA & $\mathrm{H} 1^{\prime}$ & 15 & RA & $\mathrm{H} 4^{\prime}$ & 3.2 & 3.7 \\
\hline 15 & RA & $\mathrm{H} 2$ & 15 & RA & $\mathrm{H} 1^{\prime}$ & 3.9 & 5.1 \\
\hline 15 & RA & $\mathrm{H} 2$ & 16 & $\mathrm{RC}$ & $\mathrm{H} 1^{\prime}$ & 3.9 & 5.1 \\
\hline 15 & RA & $\mathrm{H} 2$ & 9 & RG & $\mathrm{H} 1^{\prime}$ & 3.9 & 5.1 \\
\hline 15 & RA & H8 & 15 & RA & $\mathrm{H} 1^{\prime}$ & 3.1 & 4.1 \\
\hline 15 & RA & H8 & 14 & $\mathrm{RC}$ & $\mathrm{H} 1^{\prime}$ & 3.9 & 5.1 \\
\hline 15 & RA & H8 & 15 & RA & $\mathrm{H} 2^{\prime}$ & 3.8 & 4.5 \\
\hline 15 & RA & H8 & 15 & RA & $\mathrm{H}^{\prime}{ }^{\prime}$ & 2.6 & 3.6 \\
\hline 15 & RA & H8 & 14 & $\mathrm{RC}$ & $\mathrm{H}^{\prime}{ }^{\prime}$ & 2.6 & 3.6 \\
\hline 15 & RA & H8 & 16 & $\mathrm{RC}$ & H5 & 3.4 & 4.6 \\
\hline 15 & RA & H8 & 14 & $\mathrm{RC}$ & $\mathrm{H} 2^{\prime}$ & 2.0 & 2.7 \\
\hline 16 & $\mathrm{RC}$ & $\mathrm{H} 1^{\prime}$ & 16 & $\mathrm{RC}$ & $\mathrm{H} 2^{\prime}$ & 2.4 & 3.1 \\
\hline 16 & $\mathrm{RC}$ & $\mathrm{H} 1^{\prime}$ & 16 & $\mathrm{RC}$ & $\mathrm{H}^{\prime}{ }^{\prime}$ & 3.4 & 4.2 \\
\hline 16 & $\mathrm{RC}$ & $\mathrm{H} 1^{\prime}$ & 16 & $\mathrm{RC}$ & H4 ' & 3.2 & 3.7 \\
\hline 16 & $\mathrm{RC}$ & H5 & 16 & $\mathrm{RC}$ & $\mathrm{H} 2^{\prime}$ & 3.9 & 5.1 \\
\hline 16 & $\mathrm{RC}$ & H5 & 15 & RA & $\mathrm{H} 2^{\prime}$ & 2.9 & 4.6 \\
\hline 16 & $\mathrm{RC}$ & H5 & 15 & RA & $\mathrm{H}^{\prime}{ }^{\prime}$ & 2.9 & 4.1 \\
\hline 16 & $\mathrm{RC}$ & H5 & 16 & $\mathrm{RC}$ & H3 ' & 3.9 & 5.1 \\
\hline 16 & $\mathrm{RC}$ & H6 & 15 & RA & $\mathrm{H} 1^{\prime}$ & 3.9 & 5.1 \\
\hline 16 & $\mathrm{RC}$ & H6 & 16 & $\mathrm{RC}$ & $\mathrm{H}^{\prime}{ }^{\prime}$ & 3.4 & 4.3 \\
\hline 16 & $\mathrm{RC}$ & H6 & 15 & RA & $\mathrm{H} 2^{\prime}$ & 1.9 & 3.1 \\
\hline 16 & $\mathrm{RC}$ & H6 & 15 & RA & $\mathrm{H}^{\prime}{ }^{\prime}$ & 2.9 & 4.1 \\
\hline 16 & $\mathrm{RC}$ & H6 & 16 & $\mathrm{RC}$ & H3 ' & 2.9 & 4.1 \\
\hline 16 & $\mathrm{RC}$ & N1 & 7 & $R G$ & N9 & 8.6 & 9.0 \\
\hline 17 & $R G$ & $\mathrm{H} 1^{\prime}$ & 17 & $R G$ & $\mathrm{H} 2^{\prime}$ & 2.4 & 3.1 \\
\hline 17 & RG & $\mathrm{H} 1^{\prime}$ & 17 & RG & $\mathrm{H} 4^{\prime}$ & 3.2 & 3.7 \\
\hline 17 & $\mathrm{RG}$ & H8 & 17 & RG & $\mathrm{H} 1^{\prime}$ & 3.1 & 4.1 \\
\hline 17 & $\mathrm{RG}$ & H8 & 16 & $\mathrm{RC}$ & $\mathrm{H} 1^{\prime}$ & 3.9 & 6.1 \\
\hline 17 & $R G$ & H8 & 17 & $R G$ & $\mathrm{H} 2^{\prime}$ & 3.8 & 4.5 \\
\hline 17 & $\mathrm{RG}$ & H8 & 16 & $\mathrm{RC}$ & $\mathrm{H} 2^{\prime}$ & 1.9 & 2.6 \\
\hline 17 & RG & H8 & 17 & RG & H3 ' & 2.6 & 3.6 \\
\hline 17 & $R G$ & H8 & 16 & $\mathrm{RC}$ & H3 ' & 2.6 & 3.6 \\
\hline 17 & RG & H8 & 16 & $\mathrm{RC}$ & H5 & 3.9 & 5.6 \\
\hline 17 & $R G$ & H8 & 18 & RU & H5 & 3.9 & 5.6 \\
\hline 18 & RU & $\mathrm{H} 1^{\prime}$ & 18 & RU & $\mathrm{H} 2^{\prime}$ & 2.4 & 3.1 \\
\hline 18 & RU & $\mathrm{H} 1^{\prime}$ & 18 & RU & $\mathrm{H}^{\prime}{ }^{\prime}$ & 3.4 & 4.2 \\
\hline 18 & RU & $\mathrm{H} 1^{\prime}$ & 18 & $\mathrm{RU}$ & H4 ' & 3.2 & 3.7 \\
\hline 18 & RU & H5 & 18 & RU & $\mathrm{H} 2^{\prime}$ & 3.4 & 5.1 \\
\hline 18 & RU & H5 & 17 & $R G$ & $\mathrm{H} 2^{\prime}$ & 2.9 & 4.6 \\
\hline 18 & RU & H5 & 18 & $\mathrm{RU}$ & $\mathrm{H}^{\prime}{ }^{\prime}$ & 3.9 & 5.1 \\
\hline
\end{tabular}

Supporting Information Page 78 


\begin{tabular}{|c|c|c|c|c|c|c|}
\hline 18 & $\mathrm{RU}$ & $\mathrm{H} 6$ & 18 & $\mathrm{RU}$ & $\mathrm{H} 1^{\prime}$ & 3.4 \\
\hline 18 & RU & $\mathrm{H} 6$ & 17 & $\mathrm{RG}$ & $\mathrm{H} 1^{\prime}$ & 3.9 \\
\hline 18 & RU & $\mathrm{H} 6$ & 18 & $\mathrm{RU}$ & $\mathrm{H} 2^{\prime}$ & 3.4 \\
\hline 18 & RU & H6 & 17 & $\mathrm{RG}$ & $\mathrm{H} 2^{\prime}$ & 1.9 \\
\hline 18 & RU & $\mathrm{H} 6$ & 17 & $\mathrm{RG}$ & $\mathrm{H}^{\prime}$ & 2.9 \\
\hline 18 & RU & H6 & 18 & RU & $\mathrm{H}^{\prime}$ & 2.9 \\
\hline 18 & RU & H6 & 19 & $\mathrm{RC}$ & H5 & 3.4 \\
\hline 18 & RU & N1 & 4 & RG & N9 & 8.6 \\
\hline 18 & RU & N1 & 4 & RG & N9 & 8.6 \\
\hline 19 & $\mathrm{RC}$ & H5 & 18 & RU & $\mathrm{H} 2^{\prime}$ & 2.9 \\
\hline 19 & $\mathrm{RC}$ & H5 & 18 & RU & $\mathrm{H}^{\prime}$ & 2.9 \\
\hline 19 & $\mathrm{RC}$ & H5 & 18 & $\mathrm{RU}$ & $\mathrm{H}^{\prime}$ & 2.9 \\
\hline 19 & $\mathrm{RC}$ & H6 & 18 & $\mathrm{RU}$ & $\mathrm{H} 1^{\prime}$ & 3.9 \\
\hline 19 & $\mathrm{RC}$ & H6 & 19 & $\mathrm{RC}$ & $\mathrm{H} 1^{\prime}$ & 3.4 \\
\hline 19 & $\mathrm{RC}$ & $\mathrm{H} 6$ & 19 & $\mathrm{RC}$ & $\mathrm{H} 2^{\prime}$ & 3.4 \\
\hline 19 & $\mathrm{RC}$ & H6 & 19 & $\mathrm{RC}$ & $\mathrm{H}^{\prime}$ & 2.9 \\
\hline 19 & $\mathrm{RC}$ & H6 & 18 & RU & $\mathrm{H}^{\prime}$ & 2.9 \\
\hline 19 & RC & $\mathrm{H} 6$ & 18 & $\mathrm{RU}$ & $\mathrm{H} 2^{\prime}$ & 2.0 \\
\hline 19 & $\mathrm{RC}$ & $\mathrm{H} 1^{\prime}$ & 19 & $\mathrm{RC}$ & $\mathrm{H} 2^{\prime}$ & 2.4 \\
\hline 19 & $\mathrm{RC}$ & N1 & 3 & $\mathrm{RG}$ & N9 & 8.6 \\
\hline 20 & RG & $\mathrm{H} 1^{\prime}$ & 20 & $\mathrm{RG}$ & $\mathrm{H}^{\prime}$ & 3.4 \\
\hline 20 & RG & H8 & 19 & $\mathrm{RC}$ & $\mathrm{H} 1^{\prime}$ & 3.9 \\
\hline 20 & RG & H8 & 20 & $\mathrm{RG}$ & $\mathrm{H} 1^{\prime}$ & 3.1 \\
\hline 20 & RG & H8 & 20 & RG & $\mathrm{H}^{\prime}$ & 2.6 \\
\hline 20 & $\mathrm{RG}$ & H8 & 20 & RG & $\mathrm{H} 2^{\prime}$ & 3.9 \\
\hline 20 & RG & H8 & 19 & $\mathrm{RC}$ & $\mathrm{H} 2^{\prime}$ & 2.0 \\
\hline 20 & RG & $\mathrm{H} 1^{\prime}$ & 20 & $\mathrm{RG}$ & $\mathrm{H} 2^{\prime}$ & 2.4 \\
\hline 21 & RG3 & $\mathrm{H} 1^{\prime}$ & 21 & RG3 & $\mathrm{H} 2^{\prime}$ & 2.4 \\
\hline 21 & RG3 & $\mathrm{H} 1^{\prime}$ & 21 & RG3 & $\mathrm{H}^{\prime}{ }^{\prime}$ & 3.4 \\
\hline 21 & RG3 & H8 & 20 & $\mathrm{RG}$ & $\mathrm{H} 1^{\prime}$ & 3.9 \\
\hline 21 & RG3 & H8 & 21 & RG3 & $\mathrm{H}^{\prime}{ }^{\prime}$ & 3.1 \\
\hline 21 & RG3 & $\mathrm{H} 8$ & 21 & RG3 & $\mathrm{H}^{\prime}{ }^{\prime}$ & 3.8 \\
\hline 21 & RG3 & H8 & 20 & RG & $\mathrm{H} 2^{\prime}$ & 1.9 \\
\hline 21 & RG3 & H8 & 20 & $\mathrm{RG}$ & H3 ' & 2.6 \\
\hline 21 & RG3 & H8 & 21 & RG3 & H3 ' & 2.6 \\
\hline 22 & PFA & C15 & 17 & $\mathrm{RG}$ & $\mathrm{H} 1^{\prime}$ & 3 \\
\hline 22 & PFA & C7 & 5 & $\mathrm{RC}$ & $\mathrm{H} 2^{\prime}$ & 3 \\
\hline 22 & PFA & C7 & 6 & RA & $\mathrm{H} 2^{\prime}$ & 3 \\
\hline 22 & PFA & C7 & 7 & $R G$ & $\mathrm{H} 1^{\prime}$ & 3 \\
\hline 22 & PFA & C7 & 7 & $\mathrm{RG}$ & $\mathrm{H}^{\prime}$ & 3 \\
\hline 22 & PFA & C7 & 16 & $\mathrm{RC}$ & $\mathrm{H}^{\prime}{ }^{\prime}$ & 3 \\
\hline 22 & PFA & C7 & 17 & $\mathrm{RG}$ & $\mathrm{H} 1^{\prime}$ & 3 \\
\hline 22 & PFA & C7 & 17 & $R G$ & $\mathrm{H} 1^{\prime}$ & 3 \\
\hline 22 & PFA & C7 & 22 & PFA & $\mathrm{H} 4$ & 2.5 \\
\hline 22 & PFA & $\mathrm{H} 1$ & 5 & $\mathrm{RC}$ & $\mathrm{H} 2^{\prime}$ & 3 \\
\hline 22 & PFA & $\mathrm{H} 4$ & 16 & $\mathrm{RC}$ & $\mathrm{H} 2^{\prime}$ & 3 \\
\hline 22 & PFA & $\mathrm{H} 4$ & 17 & RG & $\mathrm{H} 1^{\prime}$ & 3 \\
\hline 22 & PFA & $\mathrm{H} 4$ & 17 & $\mathrm{RG}$ & H8 & 3 \\
\hline 22 & PFA & $\mathrm{H} 4$ & 22 & PFA & C15 & 3 \\
\hline 22 & PFA & H5 & 16 & $\mathrm{RC}$ & $\mathrm{H} 2^{\prime}$ & 3 \\
\hline 22 & PFA & H5 & 17 & $\mathrm{RG}$ & $\mathrm{H} 1^{\prime}$ & 3 \\
\hline 22 & PFA & H5 & 17 & $R G$ & $\mathrm{H} 8$ & 3 \\
\hline
\end{tabular}

Supporting Information Page 79 


$\begin{array}{lllllrll}22 & \text { PFA } & \text { H5 } & 22 & \text { PFA } & \text { C15 } & 3 & 6 \\ 22 & \text { PFA } & \text { H6 } & 22 & \text { PFA } & \text { H4 } & 3 & 6 \\ 22 & \text { PFA } & \text { H7 } & 22 & \text { PFA } & \text { H4 } & 3 & 6 \\ 22 & \text { PFA } & \text { H8 } & 22 & \text { PFA } & \text { H4 } & 3 & 6\end{array}$


Table S12: NOE restraints used for modeling of stem mimic duplex bound to 9 (denoted by PFB).

\begin{tabular}{|c|c|c|c|c|c|c|c|}
\hline 1 & RC5 & $\mathrm{H} 1^{\prime}$ & 1 & RC5 & $\mathrm{H} 2^{\prime}$ & 2.03 & 3.24 \\
\hline 1 & RC5 & H6 & L & RC5 & $\mathrm{H} 1^{\prime}$ & 2.52 & 4.02 \\
\hline 1 & RC5 & $\mathrm{H}^{\prime}$ & 1 & RC5 & $\mathrm{H} 1^{\prime}$ & 2.35 & 3.75 \\
\hline 1 & RC5 & H6 & 1 & RC5 & $\mathrm{H} 2^{\prime}$ & 2.43 & 3.88 \\
\hline 1 & RC5 & H6 & 1 & RC5 & H3 ' & 1.94 & 3.09 \\
\hline 1 & RC5 & H6 & 2 & $\mathrm{RC}$ & H5 & 3.61 & 5.76 \\
\hline 2 & $\mathrm{RC}$ & H6 & 1 & RC5 & $\mathrm{H} 1^{\prime}$ & 3.00 & 6.00 \\
\hline 2 & $\mathrm{RC}$ & H6 & 1 & RC5 & $\mathrm{H} 2^{\prime}$ & 1.81 & 2.89 \\
\hline 2 & $\mathrm{RC}$ & H6 & 1 & RC5 & $\mathrm{H} 3^{\prime}$ & 1.80 & 4.50 \\
\hline 2 & $\mathrm{RC}$ & H6 & 2 & $\mathrm{RC}$ & $\mathrm{H} 2^{\prime}$ & 2.65 & 4.22 \\
\hline 2 & $\mathrm{RC}$ & H6 & 2 & $\mathrm{RC}$ & H3 ${ }^{\prime}$ & 1.98 & 3.16 \\
\hline 3 & RG & H8 & 3 & RG & $\mathrm{H} 1^{\prime}$ & 2.69 & 4.30 \\
\hline 3 & RG & $\mathrm{H}^{\prime}$ & 4 & RG & H8 & 3.53 & 5.63 \\
\hline 3 & RG & H8 & 2 & $\mathrm{RC}$ & $\mathrm{H} 2^{\prime}$ & 1.90 & 3.04 \\
\hline 4 & RG & H8 & 4 & RG & $\mathrm{H} 1^{\prime}$ & 1.80 & 4.50 \\
\hline 4 & RG & $\mathrm{H} 2^{\prime}$ & 5 & $\mathrm{RC}$ & H5 & 2.83 & 4.51 \\
\hline 4 & RG & H3 ' & 5 & $\mathrm{RC}$ & H5 & 2.52 & 4.02 \\
\hline 4 & RG & H8 & 3 & RG & $\mathrm{H} 1^{\prime}$ & 3.00 & 6.00 \\
\hline 4 & $R G$ & H8 & 3 & RG & $\mathrm{H} 2^{\prime}$ & 1.98 & 3.15 \\
\hline 4 & RG & H8 & 4 & RG & $\mathrm{H} 2^{\prime}$ & 1.80 & 4.50 \\
\hline 4 & RG & H8 & 4 & RG & H3 ' & 2.43 & 3.88 \\
\hline 5 & $\mathrm{RC}$ & $\mathrm{H} 1^{\prime}$ & 5 & $\mathrm{RC}$ & $\mathrm{H} 2^{\prime}$ & 2.24 & 3.57 \\
\hline 5 & $\mathrm{RC}$ & H6 & 5 & $\mathrm{RC}$ & $\mathrm{H} 1^{\prime}$ & 2.91 & 4.64 \\
\hline 5 & $\mathrm{RC}$ & $\mathrm{H} 2^{\prime}$ & 5 & $\mathrm{RC}$ & H5 & 3.76 & 6.00 \\
\hline 5 & $\mathrm{RC}$ & H6 & 4 & $R G$ & $\mathrm{H} 2^{\prime}$ & 1.72 & 2.75 \\
\hline 5 & $\mathrm{RC}$ & H6 & 4 & RG & H3 ${ }^{\prime}$ & 2.20 & 3.52 \\
\hline 5 & $\mathrm{RC}$ & H6 & 5 & $\mathrm{RC}$ & $\mathrm{H} 2^{\prime}$ & 2.19 & 3.49 \\
\hline 5 & $\mathrm{RC}$ & H6 & 5 & $\mathrm{RC}$ & $\mathrm{H} 3^{\prime}$ & 2.78 & 4.44 \\
\hline 6 & RA & H8 & 5 & $\mathrm{RC}$ & H6 & 3.00 & 7.50 \\
\hline 6 & RA & H8 & 6 & RA & $\mathrm{H} 1^{\prime}$ & 2.71 & 4.32 \\
\hline 6 & RA & $\mathrm{H} 1^{\prime}$ & 6 & RA & H3 ${ }^{\prime}$ & 2.86 & 4.56 \\
\hline 6 & RA & H8 & 5 & $\mathrm{RC}$ & $\mathrm{H} 1^{\prime}$ & 3.00 & 6.00 \\
\hline 6 & RA & H8 & 5 & $\mathrm{RC}$ & $\mathrm{H} 2^{\prime}$ & 1.80 & 4.50 \\
\hline 6 & RA & H8 & 5 & $\mathrm{RC}$ & H3 ${ }^{\prime}$ & 4.90 & 10.00 \\
\hline 6 & RA & H8 & 6 & RA & H3 ' & 1.80 & 4.50 \\
\hline 7 & RG & $\mathrm{H} 1^{\prime}$ & 7 & RG & $\mathrm{H} 2^{\prime}$ & 2.32 & 3.70 \\
\hline 7 & RG & H8 & 7 & RG & $\mathrm{H} 1^{\prime}$ & 2.54 & 4.04 \\
\hline 7 & RG & $\mathrm{H} 1^{\prime}$ & 7 & RG & H3 ' & 3.00 & $6.0 \odot$ \\
\hline 7 & RG & $\mathrm{H}^{\prime}$ & 8 & RU & H5 & 2.35 & 3.75 \\
\hline 7 & RG & H8 & 6 & RA & $\mathrm{H} 1^{\prime}$ & 3.00 & 6.00 \\
\hline 7 & $\mathrm{RG}$ & H8 & 6 & RA & H3 ${ }^{\prime}$ & 3.03 & 4.84 \\
\hline 6 & RA & H8 & 7 & RG & H8 & 3.00 & 7.50 \\
\hline 7 & RG & H8 & 7 & RG & $\mathrm{H} 2^{\prime}$ & 1.80 & 4.50 \\
\hline 7 & RG & H8 & 7 & RG & H3 ${ }^{\prime}$ & 1.80 & 4.50 \\
\hline 7 & RG & H8 & 8 & RU & H5 & 3.27 & 5.22 \\
\hline 8 & RU & H6 & 8 & RU & $\mathrm{H} 1^{\prime}$ & 2.71 & 4.32 \\
\hline 8 & RU & H6 & 7 & RG & $\mathrm{H} 2^{\prime}$ & 2.01 & 3.20 \\
\hline 8 & RU & H6 & 8 & RU & $\mathrm{H} 2^{\prime}$ & 2.59 & 4.13 \\
\hline
\end{tabular}




\begin{tabular}{|c|c|c|c|c|c|c|c|}
\hline 9 & $\mathrm{RG}$ & $\mathrm{H} 1^{\prime}$ & 8 & $R U$ & $\mathrm{H} 2^{\prime}$ & 3.73 & 5.95 \\
\hline 9 & $R G$ & $\mathrm{H} 1^{\prime}$ & 9 & RG & $\mathrm{H} 2^{\prime}$ & 2.23 & 3.55 \\
\hline 9 & $R G$ & H8 & 9 & RG & $\mathrm{H} 1^{\prime}$ & 2.78 & 4.44 \\
\hline 15 & RA & $\mathrm{H} 2$ & 9 & $\mathrm{RG}$ & $\mathrm{H} 1^{\prime}$ & 2.63 & 4.20 \\
\hline 9 & $R G$ & $\mathrm{H} 2^{\prime}$ & 10 & RU & H5 & 2.39 & 3.80 \\
\hline 9 & $R G$ & $\mathrm{H} 3^{\prime}$ & 9 & $R G$ & $\mathrm{H} 1^{\prime}$ & 2.97 & 4.74 \\
\hline 9 & $R G$ & H3 ' & 10 & RU & H5 & 2.69 & 4.28 \\
\hline 9 & $R G$ & H8 & 8 & RU & $\mathrm{H} 2^{\prime}$ & 2.03 & 3.24 \\
\hline 10 & RU & $\mathrm{H} 1^{\prime}$ & 10 & RU & $\mathrm{H} 2^{\prime}$ & 2.05 & 3.26 \\
\hline 10 & RU & $\mathrm{H} 6$ & 10 & RU & $\mathrm{H} 1^{\prime}$ & 1.80 & 4.50 \\
\hline 10 & RU & $\mathrm{H} 2^{\prime}$ & 11 & RG3 & $\mathrm{H}^{\prime}{ }^{\prime}$ & 3.52 & 5.61 \\
\hline 10 & RU & H3 ' & 10 & RU & H5 & 2.87 & 4.59 \\
\hline 11 & RG3 & $\mathrm{H} 1^{\prime}$ & 11 & RG3 & $\mathrm{H} 2^{\prime}$ & 2.15 & 3.43 \\
\hline 11 & RG3 & H8 & 11 & RG3 & $\mathrm{H} 1^{\prime}$ & 2.62 & 4.17 \\
\hline 13 & RA & $\mathrm{H} 2$ & 11 & RG3 & $\mathrm{H} 1^{\prime}$ & 3.06 & 4.88 \\
\hline 11 & RG3 & H3 ' & 11 & RG3 & $\mathrm{H} 1^{\prime}$ & 2.56 & 4.08 \\
\hline 11 & RG3 & H8 & 10 & RU & $\mathrm{H} 2^{\prime}$ & 1.86 & 2.96 \\
\hline 11 & RG3 & H8 & 11 & RG3 & $\mathrm{H} 2^{\prime}$ & 1.80 & 4.50 \\
\hline 11 & RG3 & H8 & 11 & RG3 & $\mathrm{H}^{\prime}{ }^{\prime}$ & 1.91 & 3.05 \\
\hline 12 & RC5 & $\mathrm{H} 1^{\prime}$ & 12 & RC5 & $\mathrm{H} 2^{\prime}$ & 2.26 & 3.60 \\
\hline 12 & RC5 & $\mathrm{H} 6$ & 12 & RC5 & $\mathrm{H} 1^{\prime}$ & 2.55 & 4.07 \\
\hline 12 & RC5 & H3 ' & 12 & RC5 & H5 & 2.99 & 4.77 \\
\hline 12 & RC5 & $\mathrm{H} 6$ & 12 & RC5 & $\mathrm{H} 2^{\prime}$ & 2.35 & 3.74 \\
\hline 12 & RC5 & H6 & 12 & RC5 & H3 ' & 1.91 & 3.05 \\
\hline 13 & RA & H8 & 13 & RA & $\mathrm{H} 1^{\prime}$ & 2.72 & 4.35 \\
\hline 13 & RA & $\mathrm{H} 2$ & 13 & RA & $\mathrm{H} 1^{\prime}$ & 3.00 & 6.00 \\
\hline 13 & RA & $\mathrm{H} 2$ & 14 & $\mathrm{RC}$ & $\mathrm{H} 1^{\prime}$ & 2.94 & 4.69 \\
\hline 13 & RA & $\mathrm{H} 1^{\prime}$ & 13 & RA & $\mathrm{H} 2^{\prime}$ & 2.34 & 3.73 \\
\hline 13 & RA & $\mathrm{H} 2^{\prime}$ & 14 & $\mathrm{RC}$ & $\mathrm{H} 1^{\prime}$ & 2.70 & 4.31 \\
\hline 13 & RA & $\mathrm{H} 2^{\prime}$ & 14 & $\mathrm{RC}$ & H5 & 2.44 & 3.89 \\
\hline 13 & RA & $\mathrm{H} 1^{\prime}$ & 13 & RA & H3 & 2.76 & 4.41 \\
\hline 13 & RA & H8 & 12 & RC5 & $\mathrm{H} 2^{\prime}$ & 1.80 & $3.0 \odot$ \\
\hline 13 & RA & H8 & 12 & RC5 & H3 ' & 2.15 & 3.43 \\
\hline 13 & RA & H8 & 13 & RA & H3 ' & 2.18 & 3.48 \\
\hline 13 & RA & H8 & 14 & $\mathrm{RC}$ & H5 & 3.40 & 5.42 \\
\hline 14 & $\mathrm{RC}$ & $\mathrm{H} 1^{\prime}$ & 14 & $\mathrm{RC}$ & $\mathrm{H} 2^{\prime}$ & 2.11 & 3.36 \\
\hline 14 & $\mathrm{RC}$ & $\mathrm{H}^{\prime}{ }^{\prime}$ & 14 & $\mathrm{RC}$ & $\mathrm{H}^{\prime}{ }^{\prime}$ & 2.65 & 4.23 \\
\hline 14 & $\mathrm{RC}$ & $\mathrm{H} 6$ & 14 & $\mathrm{RC}$ & $\mathrm{H} 1^{\prime}$ & 2.67 & 4.26 \\
\hline 14 & $\mathrm{RC}$ & H6 & 13 & RA & $\mathrm{H} 2^{\prime}$ & 1.70 & 2.71 \\
\hline 14 & $\mathrm{RC}$ & H6 & 13 & RA & H3 ' & 2.53 & 4.03 \\
\hline 15 & RA & $\mathrm{H} 1^{\prime}$ & 14 & $\mathrm{RC}$ & $\mathrm{H} 2^{\prime}$ & 3.67 & 5.86 \\
\hline 15 & RA & $\mathrm{H}^{\prime}{ }^{\prime}$ & 15 & RA & H3 ' & 3.14 & 5.00 \\
\hline 15 & RA & H8 & 15 & RA & $\mathrm{H} 1^{\prime}$ & 2.95 & 4.70 \\
\hline 15 & RA & $\mathrm{H} 2$ & 15 & RA & $\mathrm{H} 1^{\prime}$ & 3.00 & 6.00 \\
\hline 15 & RA & $\mathrm{H} 2$ & 16 & $\mathrm{RC}$ & $\mathrm{H} 1^{\prime}$ & 3.22 & 5.14 \\
\hline 15 & RA & $\mathrm{H} 1^{\prime}$ & 15 & RA & $\mathrm{H} 2^{\prime}$ & 2.51 & 4.01 \\
\hline 15 & RA & $\mathrm{H} 2^{\prime}$ & 16 & $\mathrm{RC}$ & $\mathrm{H}_{1}^{\prime}$ & 2.94 & 4.69 \\
\hline 15 & RA & $\mathrm{H} 2^{\prime}$ & 16 & $\mathrm{RC}$ & H5 & 2.73 & 4.36 \\
\hline 15 & RA & H8 & 14 & $\mathrm{RC}$ & $\mathrm{H} 2^{\prime}$ & 1.89 & 3.01 \\
\hline 15 & RA & H8 & 15 & RA & H3 ' & 2.38 & 3.79 \\
\hline 15 & RA & H8 & 16 & $\mathrm{RC}$ & $\mathrm{H} 5$ & 3.59 & 5.73 \\
\hline 16 & $\mathrm{RC}$ & $\mathrm{H} 1^{\prime}$ & 16 & $\mathrm{RC}$ & $\mathrm{H} 2^{\prime}$ & 2.49 & 3.97 \\
\hline
\end{tabular}

Supporting Information Page 82 


\begin{tabular}{|c|c|c|c|c|c|c|c|}
\hline 16 & $\mathrm{RC}$ & $\mathrm{H} 6$ & 16 & $\mathrm{RC}$ & $\mathrm{H} 1^{\prime}$ & 3.23 & 5.15 \\
\hline 16 & $\mathrm{RC}$ & $\mathrm{H} 2^{\prime}$ & 17 & RG & $\mathrm{H} 1^{\prime}$ & $3.0 \odot$ & $6.0 \odot$ \\
\hline 16 & $\mathrm{RC}$ & H3 ' & 16 & $\mathrm{RC}$ & $\mathrm{H} 1^{\prime}$ & 2.67 & 4.26 \\
\hline 16 & $\mathrm{RC}$ & H6 & 15 & RA & $\mathrm{H} 2^{\prime}$ & 1.88 & 3.00 \\
\hline 16 & $\mathrm{RC}$ & H6 & 15 & RA & H3 ' & 2.76 & 4.41 \\
\hline 16 & $\mathrm{RC}$ & H6 & 16 & $\mathrm{RC}$ & $\mathrm{H} 2^{\prime}$ & 2.66 & 4.25 \\
\hline 16 & $\mathrm{RC}$ & H6 & 16 & $\mathrm{RC}$ & H3 ' & 2.60 & 4.15 \\
\hline 17 & $R G$ & $\mathrm{H} 1^{\prime}$ & 17 & $R G$ & $\mathrm{H} 2^{\prime}$ & 2.43 & 3.88 \\
\hline 17 & $R G$ & H8 & 17 & $\mathrm{RG}$ & $\mathrm{H} 1^{\prime}$ & 2.74 & 4.37 \\
\hline 17 & $R G$ & $\mathrm{H} 2^{\prime}$ & 18 & RU & $\mathrm{H} 1^{\prime}$ & 2.81 & 4.47 \\
\hline 17 & RG & H8 & 16 & $\mathrm{RC}$ & $\mathrm{H} 2^{\prime}$ & 2.13 & 3.40 \\
\hline 17 & $R G$ & H8 & 17 & RG & $\mathrm{H} 2^{\prime}$ & 2.71 & 4.32 \\
\hline 17 & $R G$ & H8 & 18 & RU & H5 & 2.85 & 4.55 \\
\hline 18 & $\mathrm{RU}$ & $\mathrm{H} 1^{\prime}$ & 18 & RU & $\mathrm{H} 2^{\prime}$ & 2.10 & 3.35 \\
\hline 18 & RU & $\mathrm{H} 6$ & 18 & RU & $\mathrm{H} 1^{\prime}$ & 2.70 & 4.31 \\
\hline 18 & $\mathrm{RU}$ & H3 ' & 18 & RU & $\mathrm{H} 1^{\prime}$ & 2.51 & 4.01 \\
\hline 18 & $\mathrm{RU}$ & $\mathrm{H} 6$ & 17 & $\mathrm{RG}$ & $\mathrm{H} 2^{\prime}$ & 1.83 & 2.92 \\
\hline 18 & RU & H6 & 18 & RU & $\mathrm{H} 2^{\prime}$ & 1.80 & 4.50 \\
\hline 18 & $\mathrm{RU}$ & H6 & 18 & RU & H3 ' & 1.98 & 3.15 \\
\hline 19 & $\mathrm{RC}$ & $\mathrm{H} 1^{\prime}$ & 18 & RU & $\mathrm{H} 2^{\prime}$ & 3.78 & 6.02 \\
\hline 19 & $\mathrm{RC}$ & H5 & 18 & RU & $\mathrm{H} 2^{\prime}$ & 3.03 & 4.84 \\
\hline 19 & $\mathrm{RC}$ & H6 & 18 & RU & $\mathrm{H} 2^{\prime}$ & 1.71 & 2.72 \\
\hline 19 & $\mathrm{RC}$ & H6 & 18 & RU & H3 ' & 1.80 & 4.50 \\
\hline 20 & $R G$ & H8 & 20 & $\mathrm{RG}$ & $\mathrm{H} 1^{\prime}$ & 3.00 & 6.00 \\
\hline 20 & $R G$ & H8 & 19 & $\mathrm{RC}$ & $\mathrm{H} 1^{\prime}$ & 3.00 & 6.00 \\
\hline 20 & RG & H8 & 19 & $\mathrm{RC}$ & $\mathrm{H} 2^{\prime}$ & 2.01 & 3.20 \\
\hline 20 & $R G$ & H8 & 20 & $R G$ & H3 ' & 2.07 & 3.30 \\
\hline 21 & RG3 & $\mathrm{H} 1^{\prime}$ & 21 & RG3 & $\mathrm{H} 2^{\prime}$ & 2.05 & 3.28 \\
\hline 21 & RG3 & $\mathrm{H} 1^{\prime}$ & 21 & RG3 & H3 ' & 2.56 & 4.08 \\
\hline 21 & RG3 & H8 & 21 & RG3 & $\mathrm{H} 1^{\prime}$ & 2.95 & 4.71 \\
\hline 21 & RG3 & H8 & 20 & $R G$ & $\mathrm{H} 2^{\prime}$ & 1.94 & 3.09 \\
\hline 21 & RG3 & H8 & 20 & $R G$ & H3 ' & 2.50 & 3.98 \\
\hline 21 & RG3 & H8 & 21 & RG3 & $\mathrm{H} 2^{\prime}$ & 1.80 & 4.50 \\
\hline 21 & RG3 & H8 & 21 & RG3 & H3 ' & 2.04 & 3.25 \\
\hline 7 & RG & H8 & 22 & PFB & C16 & $3.0 \odot$ & 7.50 \\
\hline 6 & RA & $\mathrm{H} 1^{\prime}$ & 22 & PFB & C7 & 3.00 & 7.50 \\
\hline 7 & $\mathrm{RG}$ & H8 & 22 & PFB & C7 & 3.00 & 8.00 \\
\hline 22 & PFB & $C 7$ & 16 & $\mathrm{RC}$ & $\mathrm{H} 2^{\prime}$ & 3.00 & 8.00 \\
\hline 16 & $\mathrm{RC}$ & H5 & 22 & PFB & C7 & $3.0 \odot$ & 7.50 \\
\hline 17 & $R G$ & H1' & 22 & PFB & C7 & 3.00 & 7.50 \\
\hline 17 & $R G$ & H8 & 22 & PFB & C7 & 3.00 & 7.50 \\
\hline 22 & PFB & H3 & 22 & PFB & C7 & 2.10 & 3.30 \\
\hline 22 & PFB & $\mathrm{H} 1$ & 16 & $\mathrm{RC}$ & $\mathrm{H} 2^{\prime}$ & 3.00 & 6.50 \\
\hline 22 & PFB & $\mathrm{H} 1$ & 17 & $\mathrm{RG}$ & $\mathrm{H} 1^{\prime}$ & 3.00 & 6.50 \\
\hline 22 & PFB & $\mathrm{H} 1$ & 17 & $R G$ & H8 & 3.00 & 7.00 \\
\hline 22 & PFB & $\mathrm{H} 2$ & 17 & $\mathrm{RG}$ & $\mathrm{H} 1^{\prime}$ & 3.00 & 7.00 \\
\hline 1 & RC5 & N3 & 21 & RG3 & $\mathrm{H} 1$ & 1.80 & 2.40 \\
\hline 1 & RC5 & H41 & 21 & RG3 & 06 & 1.80 & 2.40 \\
\hline 1 & RC5 & 02 & 21 & RG3 & $\mathrm{H} 22$ & 1.80 & 2.40 \\
\hline 2 & $\mathrm{RC}$ & N3 & 20 & $R G$ & $\mathrm{H} 1$ & 1.80 & 2.40 \\
\hline 2 & $\mathrm{RC}$ & H41 & 20 & $\mathrm{RG}$ & 06 & 1.80 & 2.40 \\
\hline 2 & $\mathrm{RC}$ & 02 & 20 & $R G$ & $\mathrm{H} 22$ & 1.80 & 2.40 \\
\hline
\end{tabular}

Supporting Information Page 83 


\begin{tabular}{|c|c|c|c|c|c|c|c|}
\hline 3 & RG & $\mathrm{H} 1$ & 19 & $\mathrm{RC}$ & N3 & 1.80 & 2.40 \\
\hline 3 & RG & 06 & 19 & $\mathrm{RC}$ & H41 & 1.80 & 2.40 \\
\hline 3 & RG & $\mathrm{H} 22$ & 19 & $\mathrm{RC}$ & 02 & 1.80 & 2.40 \\
\hline 4 & RG & $\mathrm{H} 1$ & 18 & RU & 02 & 1.80 & 2.40 \\
\hline 4 & RG & 06 & 18 & RU & H3 & 1.80 & 2.40 \\
\hline 5 & $\mathrm{RC}$ & N3 & 17 & RG & H1 & 1.80 & 2.40 \\
\hline 5 & $\mathrm{RC}$ & H41 & 17 & RG & 06 & 1.80 & 2.40 \\
\hline 5 & $\mathrm{RC}$ & 02 & 17 & RG & $\mathrm{H} 22$ & 1.80 & 2.4 \\
\hline 7 & RG & H1 & 16 & $\mathrm{RC}$ & N3 & 1.80 & 2.40 \\
\hline 7 & RG & 06 & 16 & $\mathrm{RC}$ & H41 & 1.80 & 2.4 \\
\hline 7 & RG & $\mathrm{H} 22$ & 16 & $\mathrm{RC}$ & 02 & 1.80 & 2.4 \\
\hline 8 & RU & H3 & 15 & RA & N1 & 1.80 & 2.4 \\
\hline 8 & RU & 04 & 15 & RA & H61 & 1.80 & 2.4 \\
\hline 9 & RG & $\mathrm{H} 1$ & 14 & $\mathrm{RC}$ & N3 & 1.80 & 2.40 \\
\hline 9 & RG & 06 & 14 & $\mathrm{RC}$ & H41 & 1.80 & 2.4 \\
\hline 9 & RG & $\mathrm{H} 22$ & 14 & $\mathrm{RC}$ & 02 & 1.80 & 2.4 \\
\hline 10 & RU & H3 & 13 & RA & N1 & 1.80 & 2.4 \\
\hline 10 & RU & 04 & 13 & RA & H61 & 1.80 & 2.40 \\
\hline 11 & RG3 & $\mathrm{H} 1$ & 12 & RC5 & N3 & 1.80 & 2.4 \\
\hline 11 & RG3 & 06 & 12 & RC5 & H41 & 1.80 & 2.4 \\
\hline 11 & RG3 & $\mathrm{H} 22$ & 12 & RC5 & 02 & 1.80 & 2.4 \\
\hline
\end{tabular}


Table S13: Forward primers of microRNAs containing A-bulge in the same sequence context as in the tau exon 10 hairpin. Universal reverse primer (Qiagen) was used for each miRNA primer.

\begin{tabular}{l|l}
\hline Precursor MicroRNA & \multicolumn{1}{|c}{ Forward primers of microRNA } \\
\hline hsa-miR-21 & TAGCTTATCAGACTGATGTTGA \\
hsa-miR-140 & TACCACAGGGTAGAACCACGG \\
hsa-miR-199 & CCCAGTGTTTAGACTATCTGTTC \\
hsa-miR-219a & TGATTGTCCAAACGCAATTCT \\
hsa-miR-431 & TGTCTTGCAGGCCGTCATGCA \\
hsa-miR-509 & TGATTGGTACGTCTGTGGGTAG \\
hsa-miR-564 & ACACTCCAGCTGGGAGGCACGGTGTCA \\
hsa-miR-632 & GACGGGAGGCGGAGCGGGGA \\
hsa-miR-1184 & CCTGCAGCGACTTGATGGCTTCCAA \\
hsa-miR-4515 & AGGACTGGACTCCCGGCAGCCC \\
\hline
\end{tabular}

Supporting Information Page 85 
Table S14: Primers for RT-qPCR.

\begin{tabular}{|c|c|c|}
\hline Purpose & Orientation & Sequence \\
\hline $\begin{array}{l}\text { 4R tau mRNA in } \\
\text { transfected HeLa cells }\end{array}$ & Forward & 5'-GAGGCGGGAAGGTGCAGATAATTAATAAGA-3' \\
\hline $\begin{array}{l}\text { 3R tau mRNA in } \\
\text { transfected HeLa cells }\end{array}$ & Forward & 5'-CAGCCGGGAGGCGGGAAGGTGCAAATAG-3' \\
\hline $\begin{array}{l}\text { 4R and } 3 R \text { tau mRNA in } \\
\text { transfected HeLa cells }\end{array}$ & Reverse & 5'-GCCTTATGCAGTTGCTCTCC-3' \\
\hline $\begin{array}{l}\text { 4R tau in LAN5 cells } \\
\text { 4R tau in LAN5 cells }\end{array}$ & $\begin{array}{l}\text { Forward } \\
\text { Reverse }\end{array}$ & $\begin{array}{l}\text { 5'-GAGGCGGGAAGGTGCAGATAATTAATAA-3' } \\
\text { 5'-CTGGTTTATGATGGATGTTGCC-3' }\end{array}$ \\
\hline $\begin{array}{l}\text { 3R tau in LAN5 cells } \\
\text { and mouse neurons }\end{array}$ & Forward & 5'-GAAGAATGTCAAGTCCAAGATCGG-3' \\
\hline $\begin{array}{l}\text { 3R tau in LAN5 cells } \\
\text { and mouse neurons }\end{array}$ & Reverse & 5'-GACTATTTGCACCTTCCCGC-3' \\
\hline $\begin{array}{l}\text { lau pre-mRNA in } \\
\text { Chem-CLIP } \\
\text { experiments }\end{array}$ & Forward & 5'-GGAAGTGGTGTGAGTGCGTACAC-3' \\
\hline $\begin{array}{l}\text { Tau pre-mRNA in } \\
\text { Chem-CLIP } \\
\text { experiments }\end{array}$ & Reverse & 5'-CACCTTCAGCCCAACTTCCAATG-3' \\
\hline $\begin{array}{l}4 \mathrm{R} \text { tau in mouse } \\
\text { neurons }\end{array}$ & Forward & 5'-CACTGAGAACCTGAAGCACC-3' \\
\hline $\begin{array}{l}\text { 4R tau in mouse } \\
\text { neurons }\end{array}$ & Reverse & 5'-GGACGTTGCTAAGATCCAGCT-3' \\
\hline GAPDH & Forward & 5'-GGCAAATTCAACGGCACAGT-3' \\
\hline GAPDH & Reverse & 5'-GGGTCTCGCTCCTGGAAGAT-3' \\
\hline Ferritin $\mathrm{H}$ & Forward & 5'-ACTGATGAAGCTGCAGAACC-3' \\
\hline Ferritin $\mathrm{H}$ & Reverse & 5'-GTCACCCAATTCTTTGATGG-3' \\
\hline Ferritin L & Forward & 5'-CAGCCTGGTCAATTTGTACCT-3' \\
\hline Ferritin L & Reverse & 5'-CGGTCGAAATAGAAGCCCAGAG-3' \\
\hline APP & Forward & 5'-TGGCCAACATGATTAGTGAACC-3' \\
\hline APP & Reverse & 5'-AAGATGGCATGAGAGCATCGT-3' \\
\hline PrP & Forward & 5'-AAGCCTGGAGGATGGAACACT-3' \\
\hline PrP & Reverse & 5'-GTTGCTGTACTCATCCATGGG-3' \\
\hline SNCA & Forward & 5'-ACCAAACAGGGTGTGGCAGAAG-3' \\
\hline SNCA & Reverse & 5'-CTTGCTCTTTGGTCTTCTCAGCC-3' \\
\hline$\beta$-actin & Forward & 5'-CATGTACGTTGCTATCCAGGC-3' \\
\hline$\beta$-actin & Reverse & 5'-CTCCTTAATGTCACGCACGAT-3' \\
\hline 18S rRNA & Forward & 5'-GTAACCCGTTGAACCCCATT-3' \\
\hline 18S rRNA & Reverse & 5'-TCCAATCGGTAGTAGCG-3' \\
\hline
\end{tabular}




\section{REFERENCES}

1. Rehman, S. U.; Sarwar, T.; Husain, M. A.; Ishqi, H. M.; Tabish, M., Studying noncovalent drug-DNA interactions. Arch. Biochem. Biophys. 2015, 576, 49-60.

2. Kleckner, I. R.; Foster, M. P., An introduction to NMR-based approaches for measuring protein dynamics. Biochim. Biophys. Acta 2011, 1814 (8), 942-968.

3. Popenda, L.; Bielecki, L.; Gdaniec, Z.; Adamiak, R. W., Structure and dynamics of adenosine bulged RNA duplex reveals formation of the dinucleotide platform in the C:G-A triple. ARKIVOC 2009, 3, 130-144.

4. Zheng, S.; Chen, Y.; Donahue, C. P.; Wolfe, M. S.; Varani, G., Structural basis for stabilization of the tau pre-mRNA splicing regulatory element by novantrone (mitoxantrone). Chem. Biol. 2009, 16 (5), 557-566.

5. Varani, L.; Hasegawa, M.; Spillantini, M. G.; Smith, M. J.; Murrell, J. R.; Ghetti, B.; Klug, A.; Goedert, M.; Varani, G., Structure of tau exon 10 splicing regulatory element RNA and destabilization by mutations of frontotemporal dementia and parkinsonism linked to chromosome 17. Proc. Natl. Acad. Sci. USA 1999, 96 (14), 8229-8234.

6. Fessl, T.; Lilley, D. M. J., Measurement of the change in twist at a helical junction in RNA using the orientation dependence of FRET. Biophys. J. 2013, 105 (9), 2175-2181.

7. Parkesh, R.; Fountain, M.; Disney, M. D., NMR spectroscopy and molecular dynamics simulation of $r(C C G C U G C G G) 2$ reveal a dynamic UU internal loop found in myotonic dystrophy type 1. Biochemistry 2011, 50 (5), 599-601.

8. Popenda, L.; Adamiak, R. W.; Gdaniec, Z., Bulged adenosine influence on the RNA duplex conformation in solution. Biochemistry 2008, 47 (18), 5059-5067.

9. Zega, A., NMR methods for identification of false positives in biochemical screens. J. Med. Chem. 2017, 60 (23), 9437-9447.

10. Chu, S.; Zhou, G.; Gochin, M., Evaluation of ligand-based NMR screening methods to characterize small molecule binding to HIV-1 glycoprotein-41. Org. Biomol. Chem. 2017, 15 (24), 5210-5219.

11. Griffiths-Jones, S.; Grocock, R. J.; van Dongen, S.; Bateman, A.; Enright, A. J., miRBase: microRNA sequences, targets and gene nomenclature. Nucleic acids research 2006, 34 (Database issue), D140-4.

12. Larsen, U. S.; Martiny, L.; Begtrup, M., Synthesis of 4-substituted tetrahydropyridines by cross-coupling of enol phosphates. Tetrahedron Lett. 2005, 46 (24), 4261-4263. 